Florida International University FIU Digital Commons

3-11-2016

\title{
Status Competition Between the U.S. and China on the Stage of Africa
}

Vanessa C. Leon

Florida International University, vleon@fiu.edu

DOI: $10.25148 /$ etd.FIDC000217

Follow this and additional works at: https://digitalcommons.fiu.edu/etd

Part of the International Relations Commons

\section{Recommended Citation}

Leon, Vanessa C., "Status Competition Between the U.S. and China on the Stage of Africa" (2016). FIU Electronic Theses and Dissertations. 2505.

https://digitalcommons.fiu.edu/etd/2505

This work is brought to you for free and open access by the University Graduate School at FIU Digital Commons. It has been accepted for inclusion in FIU Electronic Theses and Dissertations by an authorized administrator of FIU Digital Commons. For more information, please contact dcc@fiu.edu. 


\section{FLORIDA INTERNATIONAL UNIVERSITY}

Miami, Florida

STATUS COMPETITION BETWEEN THE U.S. AND CHINA ON THE STAGE OF

AFRICA

A dissertation submitted in partial fulfillment of

the requirements for the degree of

DOCTOR OF PHILOSOPHY

in

INTERNATIONAL RELATIONS

by

Vanessa Leon

2016 


\section{To: Dean John F. Stack}

Steven J. Green School of International \& Public Affairs

This dissertation, written by Vanessa Leon, and entitled Status Competition Between the U.S. and China on the Stage of Africa, having been approved in respect to style and intellectual content, is referred to you for judgment.

We have read this dissertation and recommend that it be approved.

$\begin{array}{r}\hline \text { John F. Clark } \\ \hline \text { Erin K. Damman } \\ \hline \text { Robert E. Gutsche, Jr. } \\ \hline \text { Thomas A. Breslin, Major Professor }\end{array}$

Date of Defense: March 11, 2016

The dissertation of Vanessa Leon is approved.

Dean John F. Stack

Steven J. Green School of International \& Public Affairs

Andrés G. Gil

Vice President for Research and Economic Development and Dean of the University Graduate School

Florida International University, 2016 
(C) Copyright 2016 by Vanessa Leon

All rights reserved. 


\section{DEDICATION}

I dedicate this dissertation to my husband, who would not let me give up, no matter how difficult the journey became, and to my children, who have made sacrifices to help me achieve this goal. 


\section{ACKNOWLEDGMENTS}

I would like to thank the members of my committee for their encouragement, support, sharp eyes, and dedication to helping me be the best possible scholar. Dr. Thomas Breslin was exceptionally dedicated to ensuring I reached this goal, not only by constantly checking in, but by providing excellent advice and monthly meetings with other Ph.D. students. Dr. John Clark’s belief in my abilities has been a constant supportive presence. Dr. Erin Damman's dedication to doing good and clear science helped hone my focus. Dr. Robert Gutsche’s journalistic eye helped me to clarify and sharpen my writing. Dr. Kathy Fitzpatrick’s early contributions to my committee helped clarify the public diplomacy focus. Dr. Shlomi Dinar provided helpful comments on the final draft.

The Florida International University Department of Politics \& International Relations staff and faculty have always been supportive and provided an excellent education. Drs. Rebecca Salokar, Harry Gould and Susanne Zwingel were excellent and informative advisors. The PIR staff, including Maria Wilkinson-Diaz, Martha Rodriguez, Maria Elena Gil and Kimberly Noy, were always helpful and caring. I am grateful for support given through three years' worth of teaching assistantships. The professors I worked with, including Drs. Paul Kowert, John Clark, Astrid Arrarás, Naisy Sarduy, John Oates, Alexander Barder and Thomas Breslin, were always supportive. I am also grateful for my professors during my graduate career, including Drs. Thomas Breslin, Peter Craumer, Harry Gould, Paul Kowert, Felix Martin, Mohiaddin Mesbahi, Markus Thiel, and Julie Zheng. 
Dr. Beth Elise Whitaker of the University of North Carolina at Charlotte provided assistance on polling related to Africa. Carlos Fernandez of the FIU library was helpful in providing research assistance.

I would also like to acknowledge the University of Southern California's support through their Center on Public Diplomacy grant, awarded in 2015. 
ABSTRACT OF THE DISSERTATION

\section{STATUS COMPETITION BETWEEN THE U.S. AND CHINA ON THE STAGE OF \\ AFRICA \\ by \\ Vanessa Leon}

Florida International University, 2016

Miami, Florida

Professor Thomas A. Breslin, Major Professor

This case study traced the American reaction to Chinese activities in Africa from

the year 2000 to the present. Two keys to understanding how this reaction might unfold were power-transition theory, which predicts that rising states will challenge the hegemon in an international system in order to revise the rules, and status-based competition theories.

The U.S. appeared delayed in reacting to competition in Africa from its rising challenger there, China, until it understood that competition to be status-based. A clear, progressive reaction on the part of American leaders was traced. First, there was a split between the reactions of members of Congress and diplomats on-the-ground, who were concerned about China in Africa around the year 2005, and leaders in the White House and State Department, who publicly denied there was any kind of problem. White House and State Department leaders' reaction then grew somewhat as relative gains concerns were activated by economic and power losses in Africa. These leaders then engaged in quiet diplomacy with China and Africa, perhaps to try to socialize China and to moderate its less favorable activities. The U.S. at this time did not seem to be fully aware of the status threat China was presenting. 
However, in about 2011, the U.S. appears to have begun to perceive the status losses it had sustained in Africa. Through policy changes, discourse, summitry and public diplomacy, including social media, leaders launched what appeared to be a public campaign, designed to position the U.S. as opposed to the values of China, and as a better partner for Africans. This can be seen as status competition because the U.S. had little to gain economically in Africa and its domestic public remained unconcerned with Africa. Loss of status appears to have motivated the U.S. to take action when nothing else had, inspiring policy changes vis-a-vis Africa, the first-ever U.S.-Africa Leaders Summit, two presidential trips to Africa, and a public diplomacy campaign designed to showcase American strengths. 


\section{TABLE OF CONTENTS}

CHAPTER

PAGE

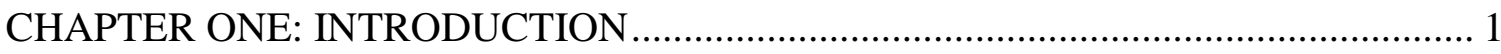

Significance of The Study .................................................................................. 3

Statement of Purpose …………………………………………………………..... 3

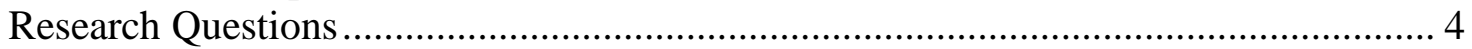

Research Outcomes/Hypotheses .............................................................................. 4

Organization of The Dissertation........................................................................... 5

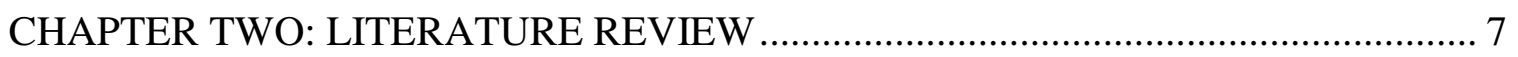

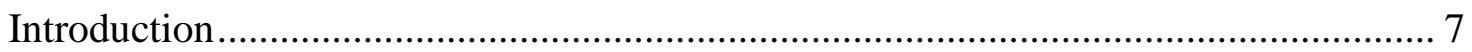

Rising States and Power-Transition Theory ……........................................................ 7

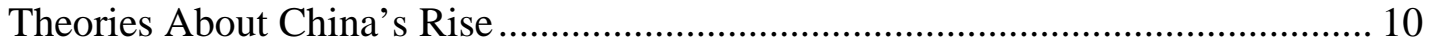

China's Peaceful Rise Strategy ………………………….................................... 12

The Impact of China's Rise on The U.S. ............................................................. 14

Prevention of Overt Competition.......................................................................... 16

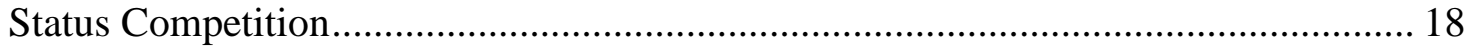

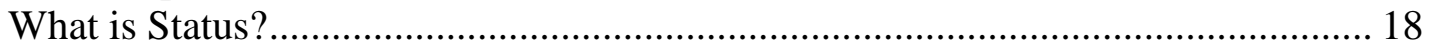

The U.S. Values Status ...................................................................................... 20

Status Competition Between the U.S. And China ……………………………........ 22

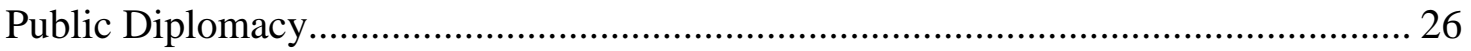

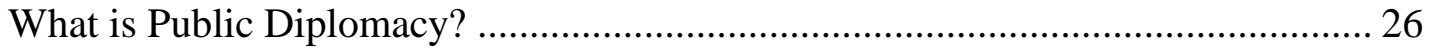

Traditional vs. New Public Diplomacy.................................................................... 27

Purposes of Public Diplomacy............................................................................... 28

Public Diplomacy and Soft/Smart Power ……………......................................... 29

Public Diplomacy Ideals ...................................................................................... 30

American Use of Public Diplomacy ....................................................................... 32

Table 1: U.S. State Department Actual Expenditures, 2008 - 2013........................... 35

Media Imperialism …………………………………….................................. 36

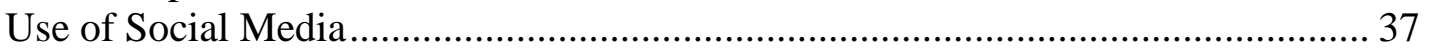

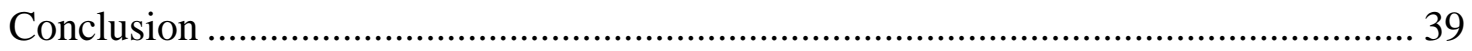

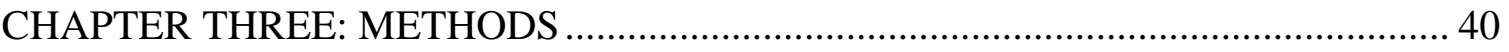

Introduction .................................................................................................... 40

Organization of The Chapter .................................................................................. 40

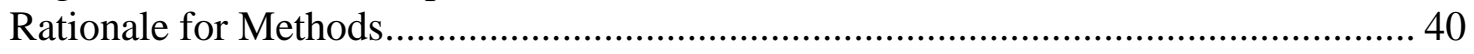

Research Design Overview........................................................................................... 43

Data Collection Methods ……………….......................................................... 44

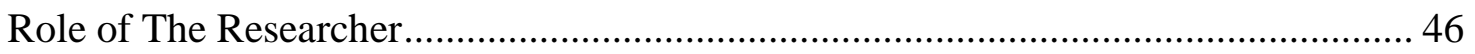

Researcher Assumptions ....................................................................................... 47

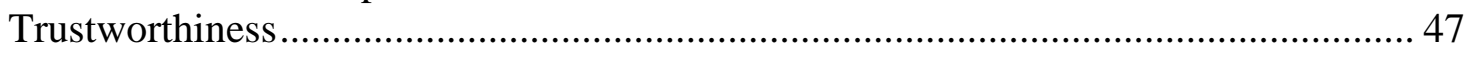

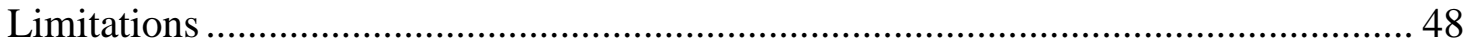


CHAPTER FOUR: THE U.S. - CHINA RELATIONSHIP ........................................ 49

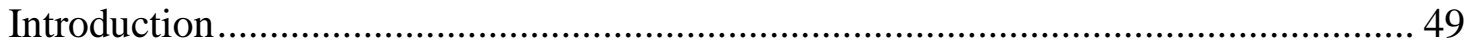

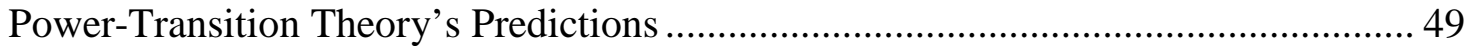

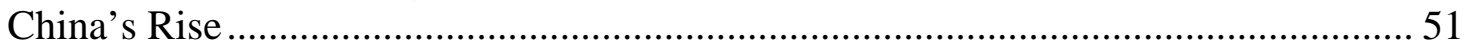

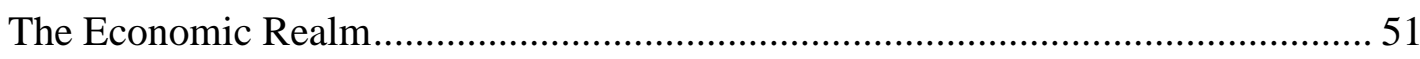

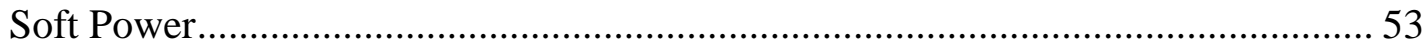

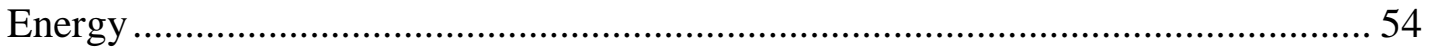

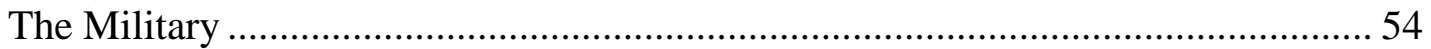

FIGURE 1: CHINA’S MILITARY EXPENDITURES, 1978 - 2006 ..................... 55

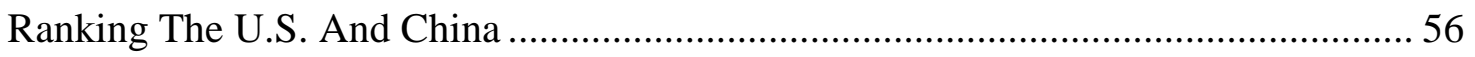

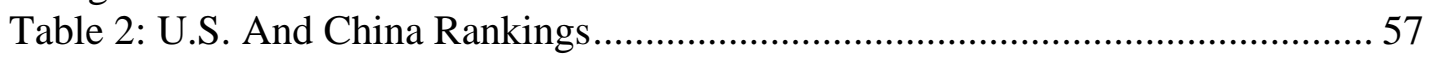

Table 3: 2010 \& 2011 National Power Index Relative Ranking .............................. 58

The American Perception of China's Rise.............................................................. 59

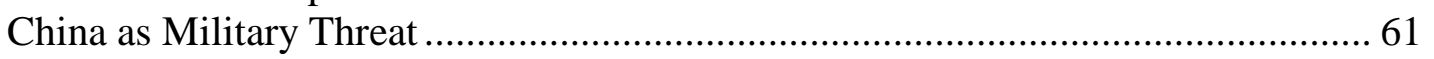

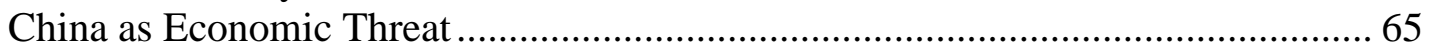

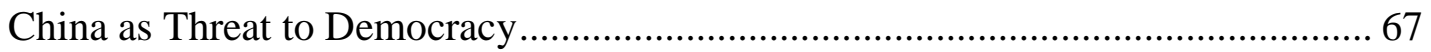

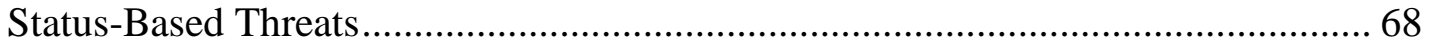

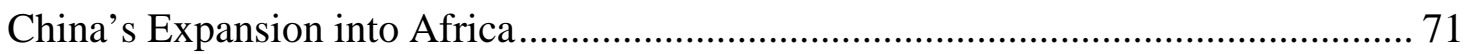

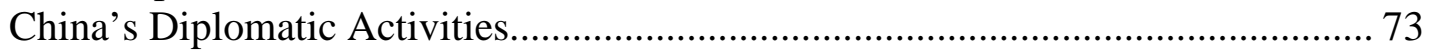

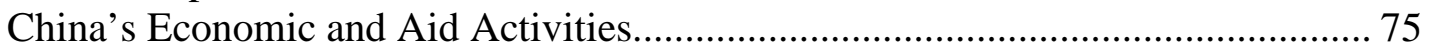

Table 4: China’s Aid to The African Continent, 2000 - 2012................................ 76

Figure 2: China’s Aid to The African Continent, 2000 - 2012 .............................. 77

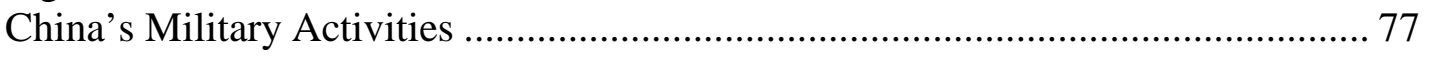

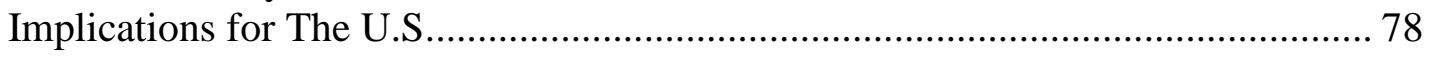

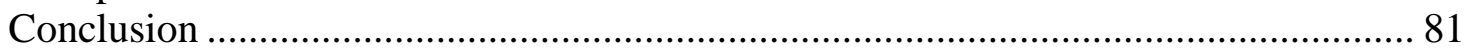

CHAPTER FIVE: EARLY REACTIONS TO CHINESE ACTIVITIES IN AFRICA ... 83

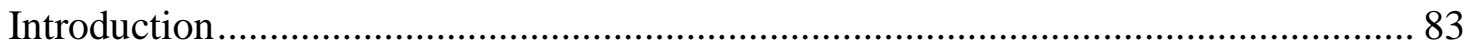

The U.S.-Africa Relationship ............................................................................ 84

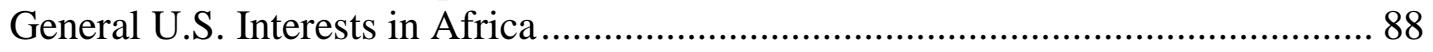

President G.W. Bush and Africa...................................................................... 96

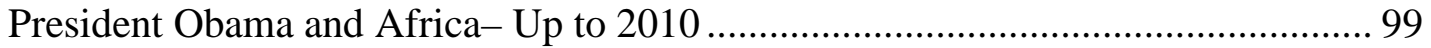

The American Understanding of Chinese Activities in Africa Before 2005 .............. 103

American Awareness of Chinese Diplomatic Summits in Africa .............................. 104

Figure 3: FOCAC Awareness Among Interview Respondents ............................ 107

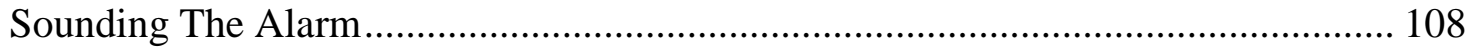

American Leaders’ Early Reaction to Chinese Activities in Africa .......................... 115

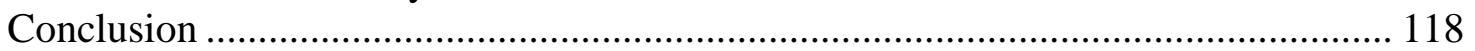

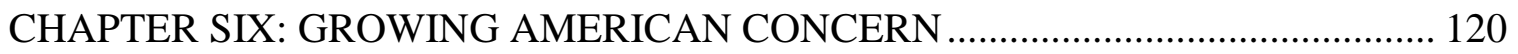

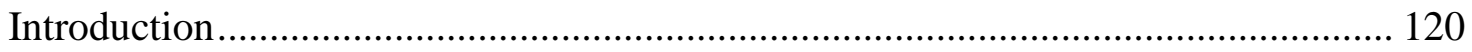

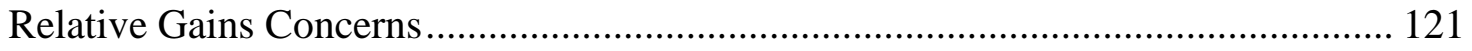

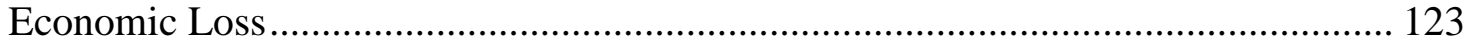

Table 5: African Trade with China and The U.S.............................................. 123 


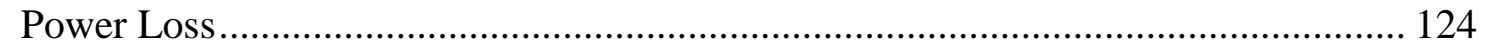

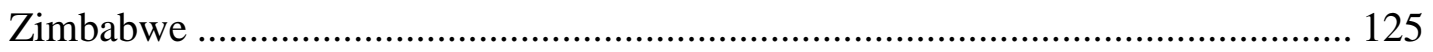

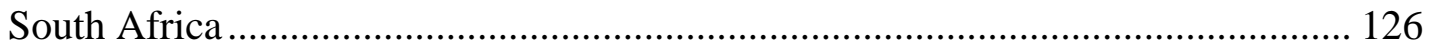

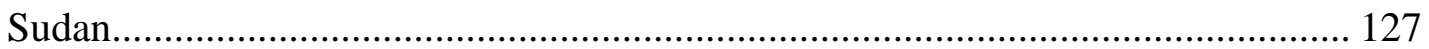

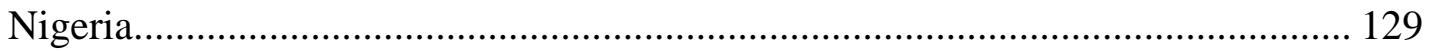

American Hegemonic Decline.............................................................................. 130

Table 6: African Approval of the United States, 2009 - 2014 ............................... 135

Quiet Diplomatic Countermeasures by The U.S..................................................... 135

U.S.-China-Africa Trilateral Meetings ………………........................................ 136

U.S.-China Diplomatic Talks............................................................................. 139

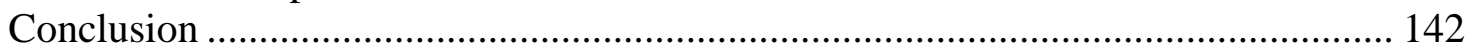

CHAPTER SEVEN: TAKING ACTION ON STATUS CONCERNS............................ 144

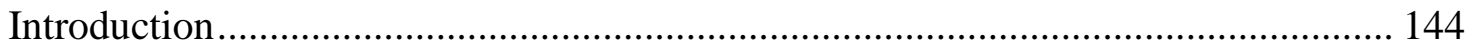

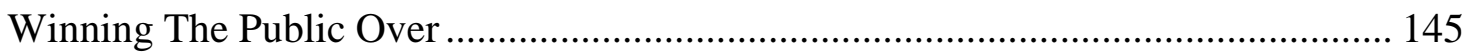

Public Diplomacy............................................................................................. 145

Table 7: U.S. State Department Social Media On Africa, 2007 - 2014 .................. 148

Figure 4: Total Number of Posts On Africa by Year............................................. 149

Figure 5: Social Media Posts by Category, 2007 - 2010.......................................... 151

Figure 6: Social Media Posts by Category, 2011 - 2014...................................... 152

Table 8: State Department Public Diplomacy Budget, 2013 - 2014 ........................ 154

U.S.-Africa Policy Changes ............................................................................... 158

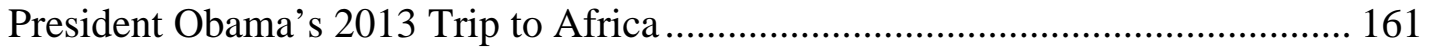

U.S.-Africa Leaders Summit............................................................................... 163

President Obama’s 2015 Trip .............................................................................. 171

Taking A Stance: U.S. Versus Chinese Values .......................................................... 173

The U.S. Advertises Itself as A Better Partner Than China........................................ 176

The American Reaction as Status Competition ............................................................ 183

The U.S. Had Little to Gain Despite “Africa Rising” Narrative .............................. 183

Table 9: Manufacturing Value Added in Exports, 2000 And 2008.......................... 184

Lack of American Domestic Support for Africa...................................................... 186

Figure 7: American View of Issues with China...................................................... 189

The Future of the U.S. And China in Africa......................................................... 190

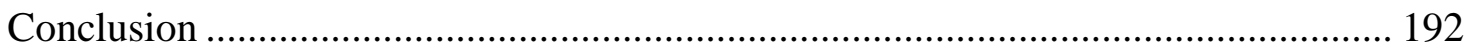

CHAPTER EIGHT: CONCLUSIONS AND DISCUSSION ............................................ 194

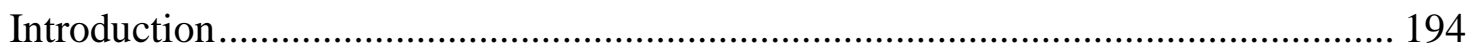

Hypotheses and Competing Explanations ……………............................................ 194

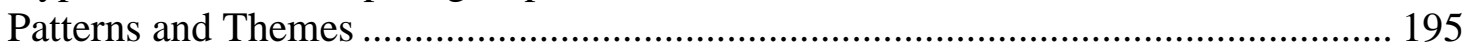

Practical and Theoretical Implications................................................................. 199

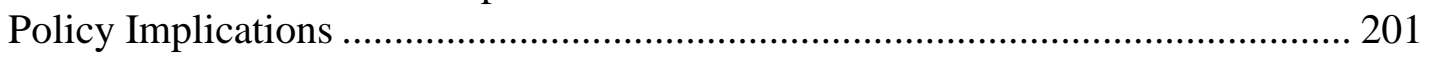

Further Topics of Research................................................................................. 203

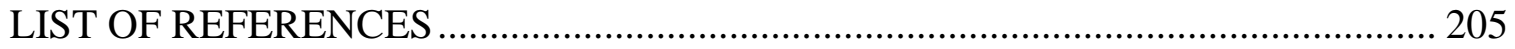

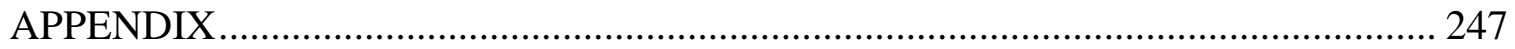

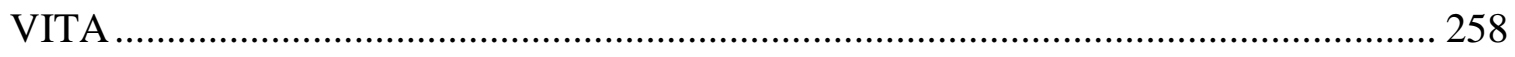




\section{LIST OF TABLES}

TABLE

PAGE

1 U.S. State Department Actual Expenditures, 2008 - 2013 .................................... 35

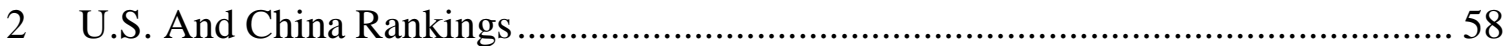

32010 \& 2011 National Power Index Relative Ranking .......................................... 59

4 China’s Aid To The African Continent, 2000 - 2012 ........................................ 77

5 African Trade With China And The U.S. ......................................................... 124

6 African Approval Of The United States, 2009 - 2014 ....................................... 136

7 U.S. State Department Social Media On Africa, 2007 - 2014 .............................. 149

8 State Department Public Diplomacy Budget, 2013 - 2014 .................................. 155

9 Manufacturing Value Added In Exports, 2000 And 2008.................................. 185 


\section{LIST OF FIGURES}

FIGURE

PAGE

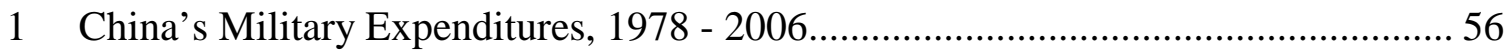

2 China’s Aid To The African Continent, 2000 - 2012 …..................................... 78

3 FOCAC Awareness Among Interview Respondents .......................................... 108

4 Total Number Of Posts On Africa By Year........................................................ 150

5 Social Media Posts By Category, 2007 - 2010................................................ 152

6 Social Media Posts By Category, 2011 - 2014.................................................. 153

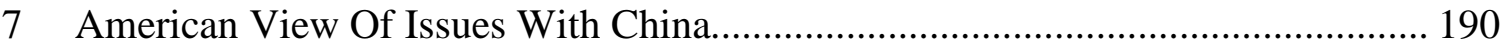




\section{ABBREVIATIONS}

ACOTA - Africa Contingency Operations Training \& Assistance

ACTE - African Competitiveness and Trade Expansion

AFRICOM - U.S. Africa Command

AGOA - African Growth and Opportunity Act

ANISOM - African Union Mission in Somalia

AU - African Union

CIA - Central Intelligence Agency

FOCAC - Forum on China-Africa Cooperation

G8 - Group of Eight Industrialized Nations

G20 - Group of Twenty Industrialized Nations

GCCI - Global Climate Change Initiative

IFI - International Financial Institution

IMET - International Military Education and Training

IMF - International Monetary Fund

IOC - International Oil Companies

JARSA - Justice as a Right in Southern Africa

MONUSCO - United Nations Organization Stabilization Mission in the Democratic Republic of the Congo

OMB - Office of Management and Budget

PEPFAR - President's Emergency Plan for AIDS Relief

PFG - Partnership for Growth

U.N. - United Nations

UNMISS - The United Nations Mission in South Sudan

U.S. - ACEF - U.S.-Africa Clean Energy Finance Initiative

USAID - United States Agency for International Development

USIA - U.S. Information Agency

USTR -United States Trade Representative 


\section{CHAPTER ONE: INTRODUCTION}

In the year 2000, with the first Forum on China-Africa Cooperation (FOCAC) summit, China demonstrated to Africa, and the world, that it believed Africa had a strong future. Since then, China has made serious inroads on the continent, winning hearts and minds through its non-interference policy and its billions in unconditional loans and projects. What was the United States to make of this? And how might the relationship between the U.S. and China on the greater international stage affect their relations in Africa?

This case study traced the American reaction to Chinese activities in Africa from the year 2000 to the present. Two keys to understanding how this reaction might unfold were power-transition theory and status-based competition theories. Power-transition theory generally states that a "rising state" (or a state becoming more powerful in the international system) will reach a point where it must challenge the dominant hegemon, usually through war, in order to change the international rules to better serve its own needs. This positions the rising state as revisionist, and the hegemon as status quo. Traditionally, then, China would be considered a rising, revisionist state, intent on grappling with the U.S., the current hegemonic, status quo state, for control of the international system. However, there are several modern developments that certainly must affect this theory. One is the character of China's rise, which has been very public, and controversial, since its economic opening in 1979; China has tried fiercely to downplay the concerns surrounding its rise, even while inflaming other concerns through aggressive regional 
activities. Another is the system China has risen into, which is thickly webbed with economic interdependence, and with prohibitions and deterrents against war (including norms against war among great powers, and nuclear weapon stockpiles). How, then, might a rising state and a hegemon actually interact, given the specific set of conditions seen today between the U.S. and China? One of the goals of this case study was to determine how the rising state/hegemon dynamic might actually be playing out today.

Status-based competition theories explain how states rank themselves and others on their relative importance within a group. Some states care a great deal about status, and will take measures to ensure their ranking is as high as possible. A hegemon generally wants to command status in order to ensure it can compel other states to do as it wishes. Status is related to power-transition in that a rising state will usually take steps to improve its status ranking, either by joining high status clubs or by participating in status markers like the Olympic Games. The hegemon, meanwhile, will usually attempt to hold onto its higher status, sometimes desperately. The problem for both is that status cannot be forced; it is the result of collective beliefs which other actors have come to on their own. There is a certain element of loss of control, then, for a hegemon which finds itself with declining status, especially to a rising state, which in turn provokes the threat of displacement. Perceived loss of status can provoke "status anxiety" and motivate a hegemon to take retaliatory action, even if it means economic loss.

This case study was designed to examine whether American activities in Africa were the result of a fear of losing Africa, or a fear of losing Africa to China, which would in turn provoke fears of decline, displacement and highly threatening status loss. Once recognition of this loss has occurred, the hegemon might try to regain status or influence 
foreign publics through a variety of measures, including imitating or insulting the competitor, appealing to leaders directly through meetings or summits, trying to reach citizens through public diplomacy, creating new policies, and more. This study examines these activities in order to answer the larger problem of whether and how a hegemon might respond to a rising state it is intimately entangled with, when its status ranking is challenged by that rising state, and it is prevented from alleviating the issue through military means or economic embargo.

\section{Significance of The Study}

Understanding how the U.S. as a hegemon is actually responding to a rising power, and whether this behavior is aligned with current theories, may address gaps between theory and reality. If American actions in Africa are a response to a stimulus provided by China, then will engagement in the continent last? Further, there may be other instances of hidden status competition between the U.S. and China, perhaps on other stages, like Latin America. This study may point the way to understanding how to find when and where this

might occur. This study also contributes to the knowledge base by exploring when and how status competition might take place between great powers on third-party regions, and how states use public diplomacy and social media when under status threat.

\section{$\underline{\text { Statement of Purpose }}$}

The purpose of this case study was to examine whether Chinese activities in Africa had stimulated status competition between the U.S. and China. If this was the case, then the U.S. should have begun to respond in highly symbolic ways to the pressure exerted by 
competition with China, even when there appeared to be few material gains. The central questions were: Has there been a demonstrable and building American reaction to Chinese activities in Africa since the year 2000 which can be seen as status competition? If so, is this reaction consistent with power transition and status-based competition theories on how a hegemon would act when faced with a challenge in a global region by a rising competitor?

\section{$\underline{\text { Research Questions }}$}

The research questions which have informed this study are: (1) How have U.S. officials reacted to Chinese summits and other activities in Africa from the year 2000 2015? (2) Has the U.S. used the United Nations and other institutions to demonstrate status competition with China over economic activities in Africa, and if so, in what ways? (3) In what ways has the U.S. communicated with African publics about Chinese economic activities in Africa? (4) In what ways has the U.S. used the U.S. -Africa Leaders Summit and other avenues to demonstrate itself as a better partner for economic activities in Africa than China? These questions allow for the final, much larger question, which is: How are these activities consistent or inconsistent with theories on how a hegemon would act when faced with a challenge in a global region by a rising competitor?

\section{Research Outcomes/Hypotheses}

There were three possible outcomes for this case study.

(1) The U.S. is engaging in similar activities as the Chinese in and regarding Africa, and these activities appear to be a form of status competition. 
(2) While the U.S. is engaging in activities in and regarding Africa in similar ways and/or locations to the Chinese, American activities and concerns do not appear to be a form of status competition.

(3) The U.S. and China are engaging in distinct, separate activities in Africa and these activities have no relationship to status competition.

\section{Organization of The Dissertation}

This dissertation is organized in the following manner:

Chapter Two is a Literature Review, which focuses on U.S.-China history in the post-Cold War era, rising state and power-transition theories, the use of Africa as a stage, status competition theories, and public diplomacy and media theories. Chapter Three will discuss Methods, including rationale, the research design overview, data collected, procedures, the role of the researcher, trustworthiness, and limitations of the study. Chapter Four will present the first outcome of this study, which is that, as China has risen in the international system, it has expanded into a territory, Africa, which had been undervalued by the hegemon, the U.S. This expansion did not provoke a U.S. response in the early stage. Chapter Five will present the second outcome of the study, which is that, as Chinese activities in the previously undervalued territory became more evident to the U.S., leaders downplayed their significance, even as others, such as members of Congress, sounded the alarm. Chapter Six will present the third outcome of the study, which is that, approximately during the period 2005 - 2011, U.S. leaders experienced a change in perception about Chinese activities in Africa, and began to take subtle, diplomatic countermeasures to address them. Chapter Seven will present the fourth outcome of the 
study, which is that, in about 2011, the U.S. began to perceive Chinese activities in Africa as a status threat. In reaction, the U.S. seemed to launch a public campaign to win African leaders back from partnership with China and positioned itself as opposed to Chinese values and a better partner for Africa. Chapter Eight will discuss the findings and make recommendations for their application. 


\title{
CHAPTER TWO: LITERATURE REVIEW
}

\author{
$\underline{\text { Introduction }}$
}

This literature review will examine theories on power-transition and status, followed by a description of public diplomacy and media theories. First, the chapter examines China's strategies in rising, the impact of this rise on the U.S. and the prevention of overt competition by strong institutions of economic interdependence, nuclear weapons and norms against great power war. Next, the chapter examines how to define status, the value the U.S. places on it, and current status competition between the U.S. and China. Finally, the chapter examines public diplomacy and social media, including information on how China and the U.S. have utilized it.

\section{$\underline{\text { Rising States and Power-Transition Theory }}$}

There are several theories that define hegemony, ${ }^{1}$ address the relationship of a hegemon to the international system, ${ }^{2}$ and predict how rising states will act in relation to

\footnotetext{
${ }^{1}$ Hegemony is usually determined by superior military power, including a navy and/or air force, a massive economy, the ability and willingness to lead and enforce the rules of the international system, and political strength. Geographic isolation is a plus.

${ }^{2}$ According to Thomas McCormick (1990), systemic schools of thought focus on hegemony rising out of economic efficiency, which leads to the generation of military power used to back up the hegemon's ideology. The hegemon enforces free trade (which benefits it the most) and acts as a global policeman; however, this eventually causes overinvestment in multinational investments abroad and in weapons production at home, and neglect of civilian industrial investments. A catch-22 results, where the hegemon must decide whether to keep military spending high, and face the domestic consequences, or cut military spending, and lose power abroad. Realist schools of thought on hegemony focus on "the maximization of geopolitical power in a global zero-sum game.” The only limits are the internal resources of a state, and the willingness of other states to resist, and the power gained is not simply economic. When a hegemon arises, it wants to maintain the status quo, which becomes increasingly expensive as competitor states threaten it. It must choose to reduce its military or decline economically. See Wallerstein, I.M. (1974), Modelski, G. (1987) and Kennedy, P. (1987).
} 
the hegemon. However, this case study will focus in particular on A.F.K. Organski's power-transition theory. Steve Chan (2008) described the theory in this way: "It contends that when a revisionist latecomer overtakes an erstwhile leader of the international system, war looms. War is likely to be precipitated by the faster-growing upstart in its attempt to displace the declining hegemon” (p. 2). The rising power is seen to have a revisionist agenda, while the dominant power is assumed to be supportive of the status quo, although Chan claimed this was not always true (p. 27-32). Power-transition theory often looks back even to Thucydides, who blamed the Peloponnesian War on the insecurity Sparta felt as Athens grew.

Robert Gilpin (1981) claimed that there is "a natural tendency for states to grow at different rates" which leads to inequality between the "existing distribution of international benefits and the evolving distribution of national power" (p. 31). The dominant state would likely attempt appeasement to prevent war with a rising state, unless it believed that the rising state would become a serious threat in the future (Chan, 2008, p. 66).

A.F.K. Organski and Jacek Kugler (1980) asserted that challenger states wanted "to redraft the rules by which relations among nations work" in order to carve out a "new place for themselves in international society.” The most dangerous time was when the challenger neared the power level of the dominant state, which became increasingly alarmed and most likely to engage in preventive war (p. 20-23). Wars of hegemonic transition included the Napoleonic, the Franco-Prussian, the Russo-Japanese, World War I and World War II. Ned Lebow and Benjamin Valentino (2009) laid out what they believed were the empirical implications of power-transition theory. They are: (1) the international system is usually dominated by one powerful state capable of imposing its will on the system, (2) this order 
benefits the powerful state in a variety of ways, (3) the more the system benefits the powerful state, the less it benefits other states, in particular, rising states, (4) power transitions result from differing rates of economic growth and have occurred in Europe, (5) war will occur between the powerful state and the rising state, initiated by either side, (6) war between the two is about defending or revising the system, and (7) war resolves the conflict between the two, one way or another (p. 392).

Not all scholars believe that power transitions will be difficult. Christopher Fettweis (2010) argued that, in the post-Bellic (a term coined by Fettweis), world great powers live in today, "rising powers would not make their neighbors overly nervous if it was generally understood that they would not seek to expand their political reach” (p. 140). Other critics believe that the theory is limited to a certain set of conditions, or that hegemonic decline may be the result of collective power among states and not as a reaction to a single rising state. ${ }^{3}$ It is certainly possible to have peaceful transitions, as occurred between the United Kingdom and United States in the $19^{\text {th }}$ century. However, power-transition theory is specifically related to a rising state which is dissatisfied with the rules and wishes to take control in order to revise them. It is this specific theory which will be investigated in this case study.

\footnotetext{
${ }^{3}$ See Snidal (1985). and Lebow and Valentino (2009).
} 


\section{Theories About China's Rise}

Michael Evans (2009) organized scholarship about the implications of China's rise into three schools of thought. The first, the "primacist" school, saw a future of "strategic competition.” Scholars like Aaron Friedberg (1998), John Mearsheimer (2014), Robyn Lim (2003) and Hugh White (2008) argued that Europe’s pre-1945 past was the Asian region's future, a world of zero-sum power politics. The combination of economic and military expansion and national interests would create crises as the power transition struggle occurs (p. 88-91). John Mearsheimer (2014) in particular has called for the U.S. to actively thwart China's rise, since he expects it to attempt regional hegemony in a manner most threatening to the U.S. Robert Art (2010) called Mearsheimer's proscription to halt China’s rise “foolhardy,” arguing that the U.S. would be gravely hurt economically and politically (p. 364). Richard Rosecrance accused Mearsheimer of being blind to “powerful but nonaggressive states” (Rapkin \& Thompson, 2013, p. 57). Jonathan Kirshner (2012) advised states "to assess the probability of their survival if they do not bid for regional hegemony, and compare that with the increased increment to their survival prospects if they achieve that hegemony against the risk to their survival, from attempting the bid” (p. 63). It is likely, he believed, that they will abandon the pursuit. He has cited classical realists who allow for the accommodation of rising powers, including Carr and Morgenthau (p. 66-67).

The second, the “exceptionalist” school, saw a future defined by China's peaceful rise. Scholars like Susan Shirk (2007), David Kang (2003), William Overholt (2008), Kenneth Johnson (2009), and Edward Burman (2008) rejected the premise of the primacist school, and believed that a robust China would create security in the Asian region. Shirk 
(2007) called China a "fragile superpower” with domestic issues it must first solve before attempting hegemony. Burman (2008) and Johnson (2009) pointed to China’s "guiding principles on U.S.-China relations,” which included creating trust and cooperation and dodging confrontation. Further, non-traditional security threats in the Asian region created a need for new forms of cooperation (Evans, p. 91-94).

The third category in Michael Evans' taxonomy, the "pragmatist” school, saw a future of competitive coexistence, filled with "complexity, uncertainty and ambiguity." Scholars like David Shambaugh (2003), Amitav Acharya (2003), Muthiah Alagappa (2003), Robert Ross (2009), Michael Swaine and Ashley Tellis (2000), and Avery Goldstein (2005) have been most influential in U.S. foreign policy. This school encouraged the U.S. to look at hard and soft capabilities and interdependence, and to have "realistic engagement” to avoid conflict while still communicating military strength. Goldstein (2005) encouraged the U.S. to look at concrete Chinese actions when creating policy. Others looked at the "contraction" of U.S. dominance and how to manage this decline (Evans, p. 94-97; 108).

G. John Ikenberry (2013) believed that China is not rising into an American system but into a Western order that it will not be able to overturn. This order is "integrated and institutionalized... a massive and far-flung global system of capitalism and democracy that continues to expand and integrate... it is deeply entrenched" (p. 56). The system is attractive to rising states as the openness facilitates trade and investment and provides rights and protections. The Chinese alternative, if one truly exists, is not feasible in the long-term (p. 57). 


\section{China’s Peaceful Rise Strategy}

Michael Swaine and Ashley Tellis (2000) viewed China’s strategy as “the acquisition of comprehensive national power deriving from a continued reform of the economy without the impediments and distractions of security competition” (p. 112). Avery Goldstein (2005) saw China’s goal as “[increasing] the country’s international clout without triggering a counterbalancing reaction" (p. 12). China wanted to become "if not an indispensable player in the global system, then at least one whose interests must regularly be taken into account.” China was "maneuvering deftly for space and opportunities not already taken up by the United States - opportunities where it can have greater freedom of action” (Congressional Research Service, 2008, p. 7).

China has developed a two-pronged strategy in its rise, although it has been flexible in the application. The first, taoguang yang-hui (hide brightness and nourish obscurity) was Deng Xiaoping's prescription in the 1990s. The second, zhonghe guoli (develop comprehensive national strength), was about becoming a global actor, with the military and diplomatic capability to back up its claims (Zhao, 2008, p. 24-25). Chinese objectives included allowing for continued strong economic growth, keeping a calm relationship with

the U.S. to ensure freedom of the seas, isolating Taiwan, taking part in bilateral and multilateral relationships, and quietly contesting U.S. primacy (Congressional Research Service, 2008, p. 4-9). China was attempting to show its neighbors and the world that it was "a responsible and cooperative member of the international community" and to exercise multilateral and bilateral policies that "demonstrate[d] the advantages of dealing with China” (Goldstein, 2005, p. 188). 
Andrew Hurrell (2006) maintained that "China is in a league of its own. It is not simply that its power resources and potential development are of a different order; it is also that its power has been combined with a long-term sense of where it would like to be [maintaining] strength and coherence. It has also shown awareness of the degree to which its rising power is potentially viewed as threatening by others” (p. 19). China's rise cannot help but impact the international system, Richard Bernstein and Ross Munro (1997) argued, since it is not only entering "an era of restored national greatness" but is "so big and so naturally powerful" that it will dominate at least the region, even without that intention (p. 53). Robert Art (2010) called China’s rise its own to lose, “either through a self-defeating diplomacy abroad or gross political and economic malfeasance at home” (p. 366).

China has been very aware of its actual and potential impact on the international system, and has attempted to manage the perceptions of other states, especially the U.S. However, it cannot hide its very different approach to international politics, as will be seen in later chapters. This can be particularly seen in its insistence on non-interference in other countries' political workings, a distinctive difference from the U.S. Further, China's political system, which today is a kind of authoritarian capitalism, Communist in name only, is quite different from and threatening to the U.S. A rising state with these distinctive characteristics, even one that has taken pains to appear peaceful, will very likely create suspicion and fear in the hegemonic state. This will be explored in the next section. 
The Impact of China's Rise on The U.S.

David Lampton (2008) claimed that: "For the Chinese, the gamble is that the Americans will countenance, indeed cooperate with, their rise, even as they have misgivings... And for America, the bet is that a powerful China two or more decades hence, woven into the fabric of international society and a beneficiary of the globalization that energized its growth in the first place, will become... 'a responsible, decent role model for others'” (p. 2). To this end, China has not challenged U.S. "core national interests," sovereignty or territory; it has not attempted to be the sole hegemon in its region; it claims military modernization is for defensive purposes only; and is not actively seeking to “export its ideology” (Wu, 2013, p. 381-382). Yet, although China has "sought to accommodate itself to U.S. power and to seek coincidences of interest... [and] has criticized but acquiesced in U.S. policies with which it has fundamentally disagreed... this has been counterbalanced by a broadening range of stances designed both to retain flexibility if relations with Washington should deteriorate and to lay the groundwork for a more active foreign policy in the future” (Hurrell, 2006, p. 14).

Aaron Friedberg (2005) claimed there were six distinct schools of thought on U.S.China relations. "Liberal optimism," which is common among U.S. policymakers, holds that economic interdependence and international institutions will lead to good relations, and that democratization is underway in China. "Realist pessimism" is the traditional view of revisionist rising states looking to challenge the international system. "Realist optimism" is the view that China is weaker than it appears and the U.S. is still very strong, and other states will bandwagon with the U.S. "Liberal pessimism" is the view that both states face strong domestic pressures, that the PRC's basis for legitimacy is weak and dangerous, and 
that both sides harbor suspicions of the other. "Constructivist optimism" is the view that China is currently being socialized through institutions into accepting Western norms. And finally "constructivist pessimism" is the view that repeated interaction might only reinforce old identities (Friedberg, 2005, p. 12-38).

Overall, the U.S. has displayed uncertainty in its response to China's rise. The Quadrennial Defense Report (QDR) of the U.S. for 2001 looked at military competitors in terms of capacity and resources, and noted that one would arise, although it went unnamed. In the 2006 QDR, China's capacity to be a military competitor with the U.S. was explicitly designated (Zhao, 2008, p. 16). The QDRs signaled a "quiet arms race” between the U.S. and China; the U.S. was "racing to maintain its sizable lead, looking over its shoulder because it sees China as a potential future military threat” (Meredith, 2007, p. 173).

In 2005, Deputy Secretary of State Robert Zoellick invited China to work with the U.S. cooperatively, and to become a "responsible stakeholder" in the existing international system, allowing both the U.S. and China to "pursue shared interests" (Zhao, 2008, p. 20). The 'responsible stakeholder' call has had limited success, as China does not truly share America's idea of responsibility and it continues to be reluctant to take on the burden of leadership (Glaser, 2013, p. 173).

There was a great deal of anti-China sentiment in the U. S. during President Bush’s second term, as the media ramped up its China coverage. Robert Hathway (2008) argued that the American domestic political situation provided incentives for being tough on China, but few benefits for those who called for good relations. 
Congress was able to use anti-China bills to send a message to its domestic audience, to warn China, or to nudge the President, knowing the bill would never become a law. Further, the U.S. had little understanding of Chinese history, and refused to see China on its own terms, separate from U.S. standards (p. 62).

\section{Prevention of Overt Competition}

Economic interdependence, nuclear deterrence and new international norms against great power war may be major brakes on overt military confrontation between the U.S. and China. Today, Yang Jiemian (2009) argued, "international society has realized the catastrophic consequence of nuclear conflict and the reality of interdependence in the globalization era. Therefore, states now seek peaceful means instead of war to satisfy their interests and redistribute power." Transitions are "peaceful and gradual," taking place within institutions; these institutions are not overcome or abolished but improved. This peacefulness is supported by the people of the world, he claimed (p. 138-139). There are, of course, many variations of distrust and competition which might occur between true peacefulness and outright war.

So far, these three brakes may have been influential in preventing direct competition or war between the U.S. and China. However, Thomas Donnelly and Colin Monaghan (2007) saw a covert aim in Chinese diplomacy: "to balance American power, create an alternative model of governance, and frustrate the ability of the international community to uphold its norms" (p. 4). China has engaged in "soft balancing" to "raise the costs of U.S. policies in international institutions... to challenge dominant U.S. preferences, and to withhold the effective... cooperation on which the fulfillment of U.S. foreign policy 
goals depends” (Hurrell, 2006, p. 15). China has felt the need to balance U.S. power where it can, to stop the U.S. from "laying down the law" or further imposing its ideals and actions (p. 16). Competition has been squeezed into a smaller, less vocal space, perhaps.

Robyn Meredith (2007) foresaw a coming "complex dance of containment and counter containment. The United States and China are not enemies, but it is hard to imagine they will be allies when both nations see their strategic interests to be in conflict” (p. 173). David Shambaugh (2013) saw the U.S.-China relationship as being one of "coopetition," where the competitive aspects were becoming more dominant, while the cooperative elements were receding (p. 4-5).

Under power-transition theory, we should see the U.S. and China becoming more and more competitive and conflict-prone, as they become more equal in power. China, rather than continuing to "hide its brightness" should become more assertive in its region and internationally. War may not be looming but the relationship will likely become increasingly more difficult. 


\section{$\underline{\text { Status Competition }}$}

This section will describe general theories about status in the international system, and then describe status competition between the U.S. and China.

\section{What is Status?}

Reinhard Wolf (2014) saw status as “an actor’s relative position within a social group,” with top ranking reserved for actors deemed most important (p. 188). Humans are innately status-oriented, and at the individual level constantly engage in ranking those around them (Larson, et al., 2014, p. 18). At the national level, ${ }^{4}$ humans take pride in their collective status and will compare their state or society to a "reference group [or state] that is similar or slightly higher in status” and has other similar characteristics, like size (Larson \& Shevchenko, 2014, p. 37-39). Actors may be revisionist (trying to improve current status) or defensive (protecting current rank) (p. 188). Deborah Larson, T.V. Paul and William Wohlforth (2014) added to this definition by calling status "collective beliefs about a given state’s ranking on valued attributes (wealth, coercive capabilities, culture, demographic position, sociopolitical organization, and diplomatic clout).... it is collective, subjective and relative... recognized through voluntary deference by others” (p. 8-10). The collective nature of status means that, despite small disagreements, there is a general accord on ranking. The subjective nature of status means that it is based on others' perceptions of

\footnotetext{
${ }^{4}$ Social identity theory, which states that people identify with a social group, and then compare their in-group with out-groups, can be brought up to the state level, although it is challenging. If state leaders identify with their state, William Wohlforth (2009) posits, then "they can be expected to derive utility from its status in international society.” At the state level, especially among similarly endowed actors, uncertainty may cause status inconsistency to occur. The lower-ranked state will use the higher-ranked as a referent group and respond with identity-maintenance strategies (p. 35-39).
} 
tangible and intangible attributes. It cannot be reached through force. The relative nature of status means that it is "socially scarce", although not always zero sum (Larson, et al, 2014, p. 8-10).

Vincent Pouliot (2014) cautioned that status is not just perception. It is an irreducible social reality, embedded in layers of meanings, an 'illusion' or game which appears to be the normal way of the world. It changes the way people interact with the world, but they would never think of not participating (p. 196-198). William Wohlforth (2009) saw status not as a strategy but as a "basic disposition" that may sometimes cause people to "behave in ways that directly contradict their material interest in security and/or prosperity” (p. 35).

Status can manifest itself as (1) membership in a club or (2) relative standing within a club, and it can be demonstrated through status markers, such as the G8, the United Nations Security Council or the Olympics. Institutions that serve as great power clubs create a symbolic difference between the ins and the outs, endow material privileges, and perpetuate the arrangement of dominant versus rising states (Paul \& Shankar, 2014, p. 173174). Status is distinct from power. Having status might make it easier to use power, but status is voluntary and more broadly based. Exercising power, through the promotion of a new norm, for instance, might increase status as well. Status also differs from authority, which is the legitimate right to direct or rule another state. Prestige, or being publicly recognized for having good qualities, is different from being ranked in a hierarchy. Honor involves pursuing a code of conduct associated with membership in a club; it may be won or lost but it is not competitive (Larson, et al, 2014, p. 13-16). Volgy et al. (2014) claimed that status attribution is bidirectional (states must seek it, as well as receive it) and three- 
pronged (consisting of self-ascription, attribution by the international community, and attribution by major powers). In order to achieve attribution, a state must have "an expansive foreign policy” to begin with, which will grow with added status and responsibility (p. 4).

States want high status in order to compel respect, cause other states to concede their policies in deference to the higher status state in cases of emergency and the everyday, and to allow for the gratification of core values and beliefs. Status is both sticky and fungible, outlasting, at times, the original circumstances of formation (Larson, et al., 2014, p. 18). High status can reduce costs for a major power as well as bolster its reputation and the integrity of its global commitments (Volgy, et al., 2011, p 60-61). Vincent Pouliot (2014) found that the strong competition over ranking indicates that status is indeed desired by states (p. 194).

The U.S. Values Status

William Wohlforth (2009) found that the U.S. seems to highly value its status in the post-Cold War era. “Official U.S. strategies... call explicitly for 'maintaining U.S. predominance'... and continue to make massive investments in areas where no plausible competition exists... They have sought a large role in nearly every region of the globe despite facing no peer rival” (p. 53). To Wohlforth, it was clear that the U.S. “derives independent utility from... status as a unipole” (p. 53). 
Andrew Bacevich (2002) argued that the same basic ideals have underpinned U.S. foreign policy from Presidents Truman to Obama. They are: (1) there must be global order, (2) the U.S. is the only state with the "vision, will, and wisdom" to lead the order, and to take on permanent obligations, (3) U.S. principles should be used to order the world, as they are universal, and (4) everyone, save a few rogue states, wants the U.S. in charge (p. 20-21).

Bruce Jentleson and Steven Weber (2008) claimed that, in the 20th century, the U.S. was the "paragon and guarantor" of five ideas, which included an emphasis on peace, benign hegemony, capitalism, democracy and Western culture (p. 43). In order to uphold dominance, especially in its "unipolar moment" of the 1990s, the U.S. claimed that it was the desire for peace, democracy and human rights that drove its foreign policy, not selfinterest (p. 46). Many have seen the U.S. as an "indispensable nation," the "necessary catalyst for most significant international collaboration” (Lieber, 2002, p. 5). The U.S. has engaged in "transformational diplomacy" in order to shape the world to its preferences, which included using tools like economic aid, development projects, visits, public announcements, the training of militaries, and so on. The activities have been generally nonviolent and have not cost large sums; the goal has been to improve prestige and reputation around the world (Chau, 2006, p. 109-116).

American exceptionalism has been fueled by the notion that, wherever the U.S. might go in the world, it was there to liberate. This allowed the U.S. to follow "policies designed to advance its own interests while all the time believing, or at least claiming, that it was doing so for the benefit of mankind" (Cox, 2004, p. 28). U.S. elites have seen themselves as "masters of a larger universe in which the United States has a very special 
part to play by virtue of its unique history, its huge capabilities, and its accumulated experience of running the world for the last 50 years” (p. 39-40). Yet, the idea that this burden has been placed on a "reluctant superpower," which then acts only "under duress and then always for the noblest purposes" continues to be entrenched in U.S. visions of itself. This notion is useful in fighting off in-depth examination of the legitimacy of U.S. preponderance (Bacevich, 2002, p. 8-9).

\section{Status Competition Between the U.S. And China}

At the international level, anarchy leads to status competition among major powers, ${ }^{5}$ since there is no higher authority capable of rank ordering states (Larson, et al., 2014, p. 17). Vincent Pouliot (2014) pointed out that "lack of central authority over symbolic forms means competition will become even more salient and intense precisely because rules of attribution and stratification are inherently contested and contestable” (p. 194). Deborah Larson and Alexei Shevchenko (2014) held that rising powers attempt to gain status by either emulating dominant states, or competing against them. A declining power will be less likely to passively accept status loss, especially as any improvement in the lower-status state's ranking likely has a relative effect on the higher. If there are just two groups competing for status, the higher will react strongly to keep its position, as loss of status can be quite painful (p. 35-41).

\footnotetext{
${ }^{5}$ A major power is defined as one which "(1) has the opportunity to act as one through unusual capabilities, (2) demonstrates its willingness to act as one by using those capabilities to pursue unusually broad and expansive foreign policies beyond its own region and does so relatively independent of other major powers, and (3) is attributed an unusual amount of status by policy makers of other states within the international community" (Volgy, 2014, p. 62). These major powers may be further stratified into superpower (power projection, accepted ranking), great power (salient at systemic level), and regional power (not salient at systemic level) (Buzan, 2004).
} 
William Wohlforth (2014) noted that the standard way of looking at status competition involves "status dissonance," where the lower-status state perceives a gap between how other states perceive it and how it believes it should be perceived or ranked. As the lower-status state takes measures to correct the misperception, it is often seen as acting aggressively, which provokes higher-status states into resisting it, perhaps even entering into conflict. The dissonance only ends when the higher-status states revise their perception or the lower-status accepts its ranking (p. 118).

Tudor Onea (2014) claimed that very little literature has looked at the response of a dominant state to a rising challenger. He believed that "a dominant state is also worried about its identity, values, and way of life, which are tied to the conservation of its high status” (p. 126). "Status anxiety” occurs when a higher-status state believes that a rising state may overtake it soon, and that it has suffered a decline in dimension(s) comparatively; it can cause "a dominant actor to impede the new arrivals' advancement, to conserve superiority in the areas in which it is still ahead, and to recoup losses in those in which it has fallen behind” (p. 133). The dimensions include military and economic capabilities, as well as prestige, particularly the kind achieved through a victory (p. 133-134). Taking risky action to protect current status from loss is more likely than risky action to improve status (p. 135). If this loss is occurring in one arena, the dominant state will probably take economic action; however, escalation to conflict could eventually occur. Loss of territory is not the concern; it is the "de facto abdication of its superior rank" that the dominant state fears (p. 137-138). 
Jeffrey Taliaferro’s (2004) "balance-of-risk” theory made the argument that “the aversion of senior officials to perceived losses - in terms of their state's relative power, international status, or prestige - drives great power intervention in peripheral regions” (p. 3). ${ }^{6}$ Leaders must use limited information to extrapolate the future political situation from current trends in relative capabilities; power today does not eliminate fear of decline in the future (p. 36-42). Further, Volgy et al. (2014) saw evidence that structural strength, which is "the strength a major power possesses with which to effectuate the course of global affairs, or for a regional power to create order within its region” was dwindling, even as relative strength increases. This made status attribution even more vital (p. 5).

Zbigniew Brzezinski (2012) argued that "the United States is still preeminent but the legitimacy, effectiveness, and durability of its leadership is increasingly questioned worldwide because of the complexity of its internal and external challenges” (p. 21). Remaining alluring to the world will only result if the U.S. can show its "capacity for a superior performance of its societal system" (p. 35). The U.S. is "facing a global competition of ideas" and must "outcompete others for market share"; it cannot ignore the competence and attractiveness of other states. The competition is based on ideology, technology, consistency between domestic and international values, and "big ideas for survival” (Jentleson and Weber, 2008, p. 45-48).

David Shambaugh (2013) argued that the U.S. and China had a "facade of cooperation and harmonious exchanges” that masked suspicion and mistrust. They could not see eye to eye and their domestic publics hamper them. They were "subliminally locked

\footnotetext{
${ }^{6}$ Defined by Taliaferro (2004) as "a combination of: (1) its geographical distance from the core, and (2) the inability of the peripheral state's military forces to inflict damage on the great power's homeland” (p. 27).
} 
in a titanic struggle over competing visions of world order: The United States seeks to expand the liberal order (which very much includes liberal states), whereas China is highly ambivalent about and often opposed to the liberal order (particularly when liberal states seek to use coercion and intervention against illiberal regimes)” (p. 21). Robert Sutter (2013) claimed that suspicion has led to mutual application of the "Gulliver strategy," where powerful states are tied down through interdependence; this has created a sort of "positive stasis" that is nevertheless underlain by "conflicting interests” (p. 154). Further, the relationship has been fraught with "remarkable twists and turns" making it brittle and ambiguous (p. 155). “China combines a scale, complexity, residual Communist ideology, and obscurity that makes it a stage upon which Americans can act out their greatest hopes and their worst fears” (Lampton, 2001, p. 307).

Western reactions to Chinese activities in Africa in general have focused on arguments of human rights and labor violations, exploitation of natural resources and a form of contemporary colonialism. China's model for economic development ("the Beijing Consensus”) also threatens the U.S. and keeps rogue regimes in power longer, as strongly state-led growth gives the regime "time to co-opt the businesspeople and elites" (Kurlantzick, 2007, p. 58). However, Yahia Mahmoud (2010) claimed that while this might look like care on the part of the U.S., it is instead perhaps "a loss of their unchallenged political and economic hegemony." Over hundreds of years, Western countries "have interpreted and shaped African realities"; however, today "there is a new strategic framework operating on the continent and it demands new ways of operating” (p. 196-198). 


\section{Public Diplomacy}

This section will define public diplomacy, and then give a brief overview of how it is used in China and the U.S. It will then briefly discuss how governments actually use media. Understanding how states use public diplomacy and media will be key in examining how the U.S. might have used it in reaction to Chinese activities in Africa.

\section{What is Public Diplomacy?}

The term "public diplomacy” was first used by Edmund Gullion in 1965 at the opening of the Edward R. Murrow Center for Public Diplomacy at Tufts University. At that time, the Center described public diplomacy as "deal[ing] with the influence of public attitudes on the formation and execution of foreign policies. It encompasses dimensions of international relations beyond traditional diplomacy... [including] the cultivation by governments of public opinion in other countries; the interaction of private groups and interests in one country with those of another... (and) the transnational flow of information and ideas” (United States Information Agency Alumni Association, 2014). Hans Tuch (1990) defined public diplomacy as “a government's process of communicating with foreign publics in an attempt to bring about understanding for its nation's ideas and ideals, its institutions and culture, as well as its national goals and policies” (p. 3). In comparison, Jan Melissen (2005) defined official diplomacy as being made up of "relationships between the representatives of states, or other international actors.” Public diplomacy, then, "targets the general public in foreign societies and... non-official groups, organizations and individuals” (p. 5). It is “opaque and narrow” and deals with the behavior and policies of governments, not people (Wolf \& Rosen, 2004, p. 4). 
Public diplomacy has been negatively linked with propaganda, especially since it has been most prominent in the U.S. during wartime. Jan Melissen (2005) argued that the distinction between the two is that, while they both try to persuade their audience to a certain way of thinking, public diplomacy allows for two-way communication (i.e., listening to and understanding foreign publics) while propaganda attempts to negate free deliberation and communication (p. 18). It is also distinct from nation branding, which involves promoting or improving a state's general image, usually a zealous activity that mobilizes all the state's resources (p. 20).

\section{Traditional vs. New Public Diplomacy}

Traditional public diplomacy featured programs that were "pushed out to target audiences” (Ross, 2002, p. 82). Eytan Gilboa (1998) defined this older form of public diplomacy as attempting “to create a favorable image for a country's policies, actions, and political and economic system” with the assumption that changing public opinion would eventually pressure the target government into change (p. 56).

'New' public diplomacy, according to the University of Southern California Center on Public Diplomacy (2006), "starts from the premise that dialogue, rather than a sales pitch, is often central to achieving the goals of foreign policy.” This is in keeping with a move "away from... peddling information to foreigners and keeping the foreign press at bay, towards engaging with foreign audiences” (Melissen, 2005, p. 13). Public diplomacy is "an integral and substantive, not just presentational, part of the policy making process" (Riordan, 2003, p. 123). The "threads," according to Brian Hocking (2005), included democratic accountability, intensification of social networks across boundaries, innovation 
in communications technology, an active role for publics, and nation branding (p. 29-31). Times have changed and public diplomacy has evolved to keep up with globalization and the compression of time and space. Kathy Fitzpatrick (2010) saw this new public diplomacy as bringing together "the diplomatic imperatives of an increasingly interdependent global society" (p. 85). Further, the ability of people to influence government at home and abroad has dramatically increased (p. 6).

In addition, because public diplomacy deals with public goods, an individual may only benefit if the larger group collectively adopts the goods. This is different from marketing private goods, which may be purchased and enjoyed by a single individual. This need for collective adoption inevitably spawns rancor from an adversary group which sees the idea as a public bad. The risk in public diplomacy is in targeting the audience which needs to hear the message. Wolf \& Rosen (2004) saw a risk in being too broad, which can be ineffective, or in being too direct in attempting to mobilize a constituency against an adversary (p. 6-7; 20).

\section{Purposes of Public Diplomacy}

There are a variety of purposes that fall under public diplomacy's umbrella. These include advancing national interests and values, influencing foreign publics, enhancing international relations, influencing foreign governments, improving the environment of opinion, improving national security, enhancing the national image, increasing soft power and promoting democracy (Fitzpatrick, 2010, p. 93-94). Jamie Metzl, who was charged with leading public diplomacy at the time it was absorbed into the Department of State, saw the purpose as "improv[ing] our ability to prevent and mitigate foreign crises, and to 
promote understanding and support for U.S. foreign policy initiatives around the world” and "to address misinformation and incitement, mitigate inter-ethnic conflict, promote independent media organizations and the free flow of information, and support democratic participation” (Cull, 2009, p. 39-40).

Kirsten Morgensen (2015) called trust the "high prize in the public diplomacy game," creating opportunities for leaders to participate in negotiations, to get others to cooperate, take risks and spend money, and to use diplomatic rather than military solutions. Trust can be created through "persuasive communication" and is linked to "normative expectations" and behavior, along with "the perception of whether that other country can be considered a friend or an enemy and with how competent and powerful that nation is" (p. 316-319). Joseph Nye, Jr. (2008) argued that, while reputation has always been important for a nation, credibility becomes even more vital in an age of overwhelming information. The overarching goal for public diplomacy is not just to get information across or improve a national image, but to "build long-term relationships that create an enabling environment for government policies” (p. 100 - 101).

\section{Public Diplomacy and Soft/Smart Power}

Public diplomacy is often conflated with the ideas of soft power ${ }^{7}$ and smart power. ${ }^{8}$ Rhonda Zaharna (2007) clarified the relationship here, calling public diplomacy the "vehicle” governments use to "wield soft power resources" as they attempt to influence

\footnotetext{
${ }^{7}$ Defined by Joseph Nye, Jr. (2004) as the ability of a nation "to shape the preferences of others" in ways that advance national interests (p. 11).

${ }^{8}$ Defined by Ernest J. Wilson III (2008) as "the capacity of an actor to combine elements of hard power and soft power in ways that are mutually reinforcing such that the actor's purposes are advanced effectively and efficiently” (p. 110-124).
} 
foreign governments and publics. Joseph Nye, Jr. (2008) believed that public diplomacy can lead to the acquisition of soft power, primarily through communication meant to clarify foreign policy, and to build relationships and a brand. Without credibility, however, "the instruments of public diplomacy cannot translate cultural resources into the soft power of attraction” (p. 101). Kathy Fitzpatrick (2010) disagreed, saying that, while public diplomacy may result in strengthening a state's position in the international arena, its purpose is not to accomplish this. Any soft power gained is a byproduct, not an intentional goal. Instead, its purpose is "to help a nation establish and maintain mutually beneficial relationships with strategic foreign publics that can affect national interests” (p. 105).

\section{Public Diplomacy Ideals}

Connections can and should be made between public diplomacy and public relations, according to Kathy Fitzpatrick (2010). The relationship management inherent in public relations would satisfy the tenets of the 'new' public diplomacy, as well as allow for long-term strategy, alignment of policies and actions, evaluation and development of ethical principles (p. 119-120). In a study of USIA alumni, she uncovered a number of recommendations to improve public diplomacy in the future. These included: adopting a national diplomatic worldview which respects foreign publics, recognizing public diplomacy's role in advancing national interests, understanding the limits of public diplomacy, incorporating it into foreign policy-making, developing a public diplomacy that is non-partisan, creating an independent public diplomacy organization, having a presence in local communities, and allocating sufficient resources (p. 238-241). 
Overall, public diplomacy "thrives in highly interdependent regions and between countries that are linked by multiple transnational relationships and therefore a substantial degree of 'interconnectedness' between their civil societies” (Melissen, 2005, p. 10). Nicholas Cull (2010) listed seven lessons learned about public diplomacy, including: listening before speaking, connecting what is learned to policy, understanding that the goal is not to impress the domestic audience but to connect with foreign publics, managing credibility in different forms of public diplomacy, recognizing that the most credible voice is not always the sponsor government's, and making public diplomacy "everyone's business.” Privatizing key aspects of public diplomacy would make it more efficient and credible, reduce costs and bring in new expertise, Kathy Fitzpatrick (2009) argued. The cons of this approach would include loss of control and accountability, mission drift, and a general avoidance of public diplomacy tasks by actual diplomats (p. 161-168).

Pierre Pahlavi (2007) found that, in the mid-2000s, interest in public diplomacy's "concrete utility" came to the fore, with campaigns focusing on "measurable objectives," integration of funding approval and planning, and a "professional culture of evaluation" (p. 279-280). This resulted in looking at internal priorities and desires rather than at exterior targeted groups, and using available resources to produce communication (Pamment, 2013). Still, Joseph Nye, Jr. (2008) argued, "the effectiveness of public diplomacy is measured by minds changed (as shown in interviews or polls), not dollars spent or slick production packages” (p. 101). 


\section{American Use of Public Diplomacy}

Currently housed in the Department of State and managed by the Under Secretary for Public Diplomacy and Public Affairs, Richard Stengel, U.S. public diplomacy focuses on "outreach, which includes communications with international audiences, cultural programming, academic grants, educational exchanges, international visitor programs, and U.S. Government efforts to confront ideological support for terrorism” (U.S. Department of State, Under Secretary for Public Diplomacy and Public Affairs, 2014). The Under Secretary is in charge of the bureaus of Educational and Cultural Affairs, Public Affairs, and International Information Programs, as well as the Center for Strategic Counterterrorism Communications. Previously, public diplomacy was handled by the United States Information Agency (USIA).

Kathy Fitzpatrick (2010) delineated four phases in the history of U.S. public diplomacy: the War Phase (first half of the $20^{\text {th }}$ century), the Anti-propaganda Phase (Cold War), the Peace Phase (end of the Cold War to 9/11 attacks), and the Terror Phase (post9/11 attacks) (p. 16). 9/11 was a turning point for public diplomacy. The absorption of the USIA into the State Department in 1999, and the subsequent lack of attention paid to public diplomacy, combined with the failure of the U.S. to adequately address its relations with foreign publics "weakened the nation's ability to stave off the [9/11] strikes." AntiAmericanism "unchecked by a broken public diplomacy system set the stage for the attacks” Fitzpatrick claimed (p. 1). The shock of 9/11 prompted governments around the world to reconsider public diplomacy, causing them to rethink how image can be used to further foreign policy, Brian Hocking (2004) noted (p. 149). Yet, the U.S. still made faulty assumptions about foreign publics, including that they envied America or simply 
misinterpreted its foreign policy goals, ignoring that what the U.S. said might be heard differently by foreign publics (van Ham, 2005, p. 60-61).

Nicholas Cull (2008) noted that the U.S. has been "a skeptical participant in public diplomacy”, displaying a "pervasive suspicion of government information” and a pennypinching attitude (p. 499). Foreign publics have also become more discerning, able to differentiate slick marketing filled with rhetoric from the hard reality of foreign policy (van Ham, 2005, p. 63). The struggles the U.S. has had with public diplomacy show that it must be consistent with foreign policy or military actions, that “selling” images or ideas will likely not pay off, that strategies must be long-term and centrally coordinated, and that public-private partnerships that bring marketing and public relations skills to the table would be helpful (Melissen, 2005, p. 7-8).

Public diplomacy within the State Department is split into several main areas. The Bureau of Educational \& Cultural Affairs (ECA) had a budget of \$586.5 million in FY13 and \$568.6 million in FY14, making it the largest of the programs. Its goal is to create people-to-people connections, and includes academic exchange programs like Fulbright, teacher exchanges and more. The International Information Programs (IIP) area had a budget of \$52.25 million in FY13 and \$48.27 million in FY14. Speakers are often hired by the IIP in the areas of democracy and human rights, economics, foreign policy, environment, and diplomacy and development. The IIP was reorganized in 2014 to put forth a "digital-first strategy" (U.S. Advisory Commission, 2014). It "supports people-topeople conversations with foreign publics on U.S. policy priorities... [It] leverages digital communications technology to reach across platforms.” IIP also facilitates American Spaces, which are locations for foreign audiences to learn about the U.S.; IIP Interactive, 
which is an online community where foreign audiences can interact with experts and leaders from the U.S.; and ShareAmerica, which is an online platform for sharing social media content (U.S. Department of State, Bureau of International Information Programs, 2015). IIP Interactive, also called CO.NX, provides a means for the Department of State to engage in digital diplomacy, offering a range of live or on-demand courses and programs, and a number of ways to connect. Although this is a relatively new program, and archived events only go back to December 2012 for the Africa region, these direct discussions with foreign audiences can give some clues as to the U.S. reaction to Chinese engagement in Africa.

The Bureau of Public Affairs had a budget of \$6.185 million in FY13 and \$6.502 million in FY 14; it provides information to the domestic audience in order to fulfill the goal of advancing U.S. foreign policy and security interests. The Bureau sets up interviews with officials, is responsible for the state.gov website and social media, creates communications, answers questions, and helps to show how U.S. foreign policy matters to Americans.

The Broadcasting Board of Governors (BBG) is responsible for Voice of America (VOA), Office of Cuba Broadcasting (OCB), Radio Free Europe/Radio Liberty (RFE, RL), Radio Free Asia (RFA), Middle East Broadcasting Networks (MBN), and the International Broadcasting Bureau (IBB). The goals of the BBG are to provide news in areas of censorship or media that is not free, support freedom of expression, upend propaganda and extremism, show others what U.S. policy is and what it means, and support threatened media. In Africa, large audiences have been obtained in Nigeria (20.7 million), Ethiopia 
(6.9 million) and Tanzania (5.3 million). A high percentage of the population is reached in Somalia (51.6\%) and Liberia (36.3\%).

Table 1, below, shows the U.S. State Department’s expenditures from 2008 to 2013 on public diplomacy activities, showing increases in all categories.

Table 1: U.S. State Department Actual Expenditures, 2008 - 2013

In Thousands of $\$$

\begin{tabular}{|c|c|c|c|c|c|c|}
\hline & $\mathbf{2 0 0 8}$ & $\mathbf{2 0 0 9}$ & $\mathbf{2 0 1 0}$ & $\mathbf{2 0 1 1}$ & $\mathbf{2 0 1 2}$ & $\mathbf{2 0 1 3}$ \\
\hline $\begin{array}{c}\text { Regional } \\
\text { Bureaus }\end{array}$ & 280,613 & 300,487 & 382,740 & 374,654 & 326,252 & 337,382 \\
\hline $\begin{array}{c}\text { Bureau of } \\
\text { International } \\
\text { Information } \\
\text { Programs }\end{array}$ & 51,547 & 65,718 & 102,566 & 99,756 & 116,033 & 106,720 \\
\hline $\begin{array}{c}\text { Educational } \\
\text { and Cultural } \\
\text { Exchanges }\end{array}$ & 501,347 & 538,000 & 635,000 & 599,550 & 583,200 & 559,180 \\
\hline $\begin{array}{c}\text { Total Public } \\
\text { Diplomacy }\end{array}$ & 890,889 & $1,084,387$ & $1,300,652$ & $1,276,142$ & $1,195,752$ & $1,166,514$ \\
\hline
\end{tabular}

U.S. Department of State, Budget and Planning, International Affairs Budget (2015) 


\section{Media Imperialism}

According to Oliver Boyd-Barrett (2014), the media may become a conduit for political imperialism, promoting, executing, resisting or embodying it (p. 1). Past theories about the relationship between media communication and imperialism focused on the physical properties of communication methods and their relation to the power of a society (Innis, 2007, 1950), on media flowing through tools closely linked to the U.S. militaryindustrial complex (Schiller, 1992, 1969), and on the ease with which the U.S. has exported its media overseas (Tunstall, 1977). The media is intimately connected to globalization, as it provides infrastructure, advertising vehicles, demonstration of "the good life," the underpinning of financial flows, and aids intelligence gathering. Most importantly for this study, it "polices the ideological boundaries of tolerable expression at national and international levels, promoting content that increasingly serves the interests of neoliberalism...” (Boyd-Barrett, p. 120).

Both the U.S. and China have used media in an imperialistic manner. China has been upgrading its overseas media reach, spending $\$ 6.6$ billion to expand Central China Television (CCTV), China Radio International (CRI), the China Xinhua News Network (CNC), and to provide an American edition of People’s Daily and China Daily. Africa Weekly, a part of China Daily, has also been launched (Keck, 2013). Xinhua’s presence in Africa has been upgraded, with new bureaus added, stories targeted to African readers and news outlets, sometimes for free, other times very cheaply. Over time, more attention has been paid to economic issues, and to learning lessons about African problems and responding to negative Western media stories about China's activities in Africa. Xinhua tends to provide more local African news, with a more positive spin, than Western news 
agencies (Xin, 2012). These are very deliberate attempts to sway a foreign audience into accepting a major power and allow it to carry out its activities there.

According to Gutsche (2014), American media has acted in ways that justify and support a nation's identity. Using the examples of coverage in Omaha, Nebraska of U.S. soldiers fighting in Afghanistan versus coverage by the same news media of local crime, he demonstrated that the media can define victims and deviants in order to rationalize or explain violence in ways that support American institutions, like the military.

\section{Use of Social Media}

Part of this case study examines social media used by the U.S. State Department to communicate directly with domestic and foreign publics. "Digital diplomacy" has quickly become an integral part of global diplomatic strategies, according to Marcus Holmes (2015). As of 2012, he noted, the U.S. had more than 150 full-time staff at headquarters and more than 900 abroad working in this area (p. 14). Holmes fully recognizes that digital diplomacy falls under the umbrella of public diplomacy, with the end goal being "the production, dissemination and maintenance of knowledge that helps to further state interests” (p. 18). The reach of social media vastly outweighs what a traditional, on-theground diplomat might hope to achieve (p. 19). Also, social media can be useful for listening to foreign publics, giving the U.S. a sense of where change (or crisis) might be brewing (p. 27). 
According to Corneliu Bjola and Lu Jiang (2015), to examine the effectiveness of social media within public diplomacy, the following three dimensions must be probed: (1) agenda-setting with the target audience, (2) presence-expansion, or being "out there" where the target audience lives, and (3) conversation-generating, or the quality of two-way conversations (p. 74-75).

Ilan Manor and Elad Segev (2015) have taken a snapshot of the kind of image the U.S. has portrayed to the world through its social media, calling it "America's selfie." Since 2008, the U.S. has tried to use social media to repair relationships with Arab and Muslim peoples, to demonstrate moral leadership (e.g., democracy, human rights, disaster relief), and to show superior military and economic strength (p. 98-102). In a study of social media use by the U.S. embassy in China, Xin Zhong and Jiayi Lu (2013) found that the "core messages” of blogs were mainly concerned with "American politics and society, cultural exchanges and bilateral relations." Mentions of "economy and trade" and "education and visa” were rare. The goal appeared to be to “display a picture of ordinary Americans' lives and narrow the psychological gap between two peoples” (p. 545).

But is digital diplomacy effective? It may be that the U.S. has fallen victim to "slacktivism," a term coined by Malcolm Gladwell, which signifies that creating digital messages is easy and attractive, whether or not they create real change in the world (Holmes, 2015, p. 19-20). It may be that digital and face-to-face diplomacy are simply more or less effective depending on the situation at hand. 
Holmes believed that face-to-face diplomacy worked better in cases of "exogenous shock" to manage relationships, clarify intentions and construct identities. Digital diplomacy, however, was most useful in times of "incremental shifting" to gather data, analyze visuals and theorize correlations (p. 24). The social media explored in this case study is of the "incremental shifting" variety, meant to steer foreign publics into a new view of the U.S., and may therefore very well have been effective.

\section{Conclusion}

This literature review examined power-transition theory, ideas about China's rise, as well as theories of status competition, public diplomacy and media. In the next chapter, methods used in carrying out this case study will be discussed. This will include the rationale for the methods used, data collected, procedures, the role of the researcher, trustworthiness, and limitations and delimitations. 


\section{CHAPTER THREE: METHODS}

\section{$\underline{\text { Introduction }}$}

The purpose of this case study is to examine whether Chinese activities in Africa have stimulated status competition between the U.S. and China. If this is the case, then the U.S. should have begun to respond in highly symbolic ways to the pressure exerted by competition with China, even when there appear to be few material gains. The central questions are: Has there been a demonstrable and building American reaction to Chinese activities in Africa, which can be seen as status competition? If so, is this reaction consistent with status theories about how a hegemon would act when faced with a challenge in a global region by a rising competitor?

\section{$\underline{\text { Organization of The Chapter }}$}

This chapter will describe the rationale for the methods used, provide an overview of the research design, describe data collection and procedures, and detail the role of the researcher, trustworthiness, and limitations and delimitations.

\section{$\underline{\text { Rationale for Methods }}$}

The idea that a rising state might bide its time until it could overtake a hegemon, likely through aggression, is well understood in International Relations literature. What is not so well known is the effect economic interdependence, norms and nuclear deterrence might have on this situation. How might a hegemon respond if it becomes not only overextended but also threatened in non-traditional, non-military ways, and finds itself 
bound by new norms and entanglements in its response? What might the hegemon do when it looked around and noticed its claim in the world had shrunk, and it had little room to fight back?

Understanding, at least in part, this new kind of dance between rising state and hegemon was the goal of this study. It matters because we must know how great powers will interact in an international system where certain actions, such as attacking a large economic rival, are proscribed or taboo. It matters specifically because the post-Cold War great power relationship between the U.S. and China has been a difficult one, with suspicion on both sides, and an emphasis on the "management of differences." This thorniness certainly adds to the delicacy of the situation between this rising state and this hegemon. It lends an extra punch to rising state activities. In other words, is the U.S. afraid of losing Africa, or is it afraid of losing Africa to China? If the latter, China's global ambitions could be causing further degradation in the U.S.-China relationship, leading to an eventual end to the uneasy peace the two have currently struck.

The methods of investigation used in this case study (document analysis and structured elite surveys) were chosen for the ability to answer the question "Has there been a demonstrable and building American reaction to Chinese activities in Africa which can be seen as status competition?” This reaction was investigated in the form of what government representatives noticed and said, officially and unofficially, and was sometimes quite subtle.

According to J.W. Cresswell (2013), case studies are "a qualitative approach in which the investigator explores a real-life, contemporary bounded system... over time, through detailed in-depth data collection involving multiple sources of information... and 
reports a case description and case themes” (p. 97). A case study must be bounded within certain parameters, and generally follows events that are happening in the present. A case may be intrinsic (of unusual interest on its own) or instrumental (understanding a problem through the case); this case study is instrumental, striving to understand the problem of rising states in the modern international system. A good case study will involve description as well as analysis of patterns and themes (p. 98-99).

Qualitative research is generally "emergent," allowing for change as it is carried out, and interpretive, allowing the researcher to craft meaning from the data (Cresswell, 2007, p. 181-182). Steven Taylor and Robert Bogdan (1984) noted that this type of research is inductive, meaning concepts, patterns and themes are understood from the data collected (p. 5). Validity in this type of research can be achieved through triangulating data from varying sources, checking the final report with interviewees, using rich, thick description, clarifying biases, presenting discrepant information, and using an external auditor to check the project (p. 196).

A major source of data for this case study were documents, speech and Congressional hearing transcripts, all of which were analyzed to discover their manifest, or surface, and latent, or hidden, meanings (Saldana, 2011, p. 10). A further source of information included elite, structured interviews with current and former government officials. These interviewees were given the chance to provide rich, thick, anonymous written description based on detailed survey questions (see Appendix for questionnaire). 
Sixty officials were approached via email, with some receiving follow-up calls and physical letters. Officials ranged from former and current State Department employees, particularly in the African Affairs bureau, to IMF, USTR, USAID and World Bank staff. Four officials completed the survey, a six percent response rate. The insight gained from these detailed responses provided an in-depth, inside look at how officials perceived the events detailed in this case study.

\section{$\underline{\text { Research Design Overview }}$}

This case study examined whether status competition had been taking place during the years 2000 - 2015 between the U.S. and China in reaction to Chinese economic activities in Africa. The focus of this research was on the relationship between the U.S. and China, and encompassed their activities in and regarding Africa continent-wide. Data collection was based on the four research questions, which were: (1) How have U.S. officials reacted to Chinese summits and other activities in Africa from 2000 - 2015; (2) Has the U.S. used the United Nations to demonstrate status competition with China over economic activities in Africa, and in what ways; (3) In what ways has the U.S. communicated with African publics about Chinese economic activities in Africa; and (4) In what ways has the U.S. used the U.S.-Africa Leaders Summit and other avenues to demonstrate itself as a better partner for economic activities in Africa than China?

This study was separated into two distinct parts. In the first, various documents were collected and analyzed, and, in the second, government officials were surveyed. See

the Appendix for detail on types of data collected, procedures, survey questionnaire and invitation to participate. 


\section{Data Collection Methods}

Documents were gathered from available online sources, including the websites of Congress, the current White House (Obama) and archived White House (Bush), the World Bank, the IMF, FOCAC, the United Nations and the Department of State. Freedom of Information Act requests were made to the Office of Management and Budget (OMB), State Department and USTR, requesting available information on the planning of the U.S.Africa Leaders Summit, as well as on the African Growth and Opportunity Act.

All available documents were searched for references to Africa and/or China in Africa in written reports, speeches, press releases, testimony, fact sheets, and press briefings. Data were saved as individual PDF documents, which were then analyzed by this investigator; salient points were copied and pasted verbatim into a spreadsheet. Documents were actually gathered between the time period November 2014 and May 2015. Since this data was part of the public record, safeguarding/security was not necessary.

The strength of this method of analysis lay in (1) providing background knowledge on U.S. policies concerning Africa and China in Africa; and (2) providing insight into how seriously U.S. officials took China's activities in Africa. The weakness of this method of analysis lay in the rhetorical nature of much of the documents. Because officials knew their words or documents would be available to the public, they might not have been fully candid about the true U.S. reaction to these activities.

Once document analysis was complete, survey data was gathered from a range of government officials and other professionals working under either the Bush or Obama Administrations. These officials were chosen to participate based on the following criteria:

(1) they had appeared in the document analysis as a speaker or writer on subjects relevant 
to this study, (2) they were recommended by dissertation committee members, or (3) they were working in relevant departments between the period 2000 - present. This included State Department officials particularly in the Bureau of African Affairs, officials at the USTR and Department of Commerce, World Bank and IMF officials, among others.

Details on each targeted official were collected and kept in a spreadsheet on a private computer, password protected. This spreadsheet was later used as the key to track anonymous responses. Initial contact with officials was made via email in June 2015, which served as an informational letter on the study, including risks and benefits (see Appendix). Officials were asked to complete a confidential online survey via Survey Monkey (password protected account), answering a series of questions (see Appendix). All participants were given the same questions. If necessary as many as two follow up emails were sent to non-responders, at intervals of two weeks. Some participants also received mailed letters. Once participant responses were complete, they were transferred to a spreadsheet where the respondent was identified only by a letter $(A-D)$ to protect anonymity. In total, sixty officials were invited to participate and four actually did so, a six percent response rate. The findings were then analyzed to determine whether the U.S. has engaged in symbolic status competition with China on the stage of Africa and were integrated into the research chapters of this dissertation.

The strength of this method of analysis lay in gauging the real experience of American officials. Those who participated provided extremely detailed, thick, rich descriptions of their experiences, opinions and perspectives on key issues in this case study. Possible weaknesses of this method included (1) possible gaps in memory or memory that did not line up with facts, (2) hesitancy to be completely honest, despite guarantees of 
anonymity, (3) inability to survey large numbers of people, (4) difficulty finding the contact information for some officials, especially those who were active during the Bush presidency but had since retired.

\section{$\underline{\text { Role of The Researcher }}$}

In a qualitative study, the role of the researcher is crucial. According to Denzin and Lincoln (2003), data come through the "human instrument" rather than through a more abstract or objective instrument, like a machine. Therefore, the human instrument, or researcher, must be prepared to describe biases, assumptions, expectations and experiences (Greenbank, 2003), and to show whether he or she is emic (an insider) or etic (an outsider) to the processes being studied.

I am considered an outsider to the processes being studied here. The writing of this dissertation signals a career change from secondary education, and thus, I have not worked in or for any of the agencies being studied here. My interest in this subject arose primarily out of my earlier studies (Master's degree, International Studies), and from an early research focus on how countries gain status from international education rankings. This has evolved into an interest in how the U.S. perceives status threats in the world. The idea for this dissertation came from a single comment read in a brief newspaper article, which featured then-Secretary of State Hillary Clinton calling Chinese activities in Africa a new form of colonialism. Until that moment, my knowledge of Africa had been mostly centered on its humanitarian and educational needs. This question of whether China was indeed 
practicing a new form of colonialism, or whether the U.S. had something further to gain by claiming it was doing so, piqued my interest and led to this case study.

\section{Researcher Assumptions}

The researcher has the following assumptions about this topic:

(1) That the U.S. has generally neglected Africa in the past decades, and that its recent attention to Africa is an aberration.

(2) That economic interdependence, norms and nuclear deterrence are real forces that shape the foreign policies and actions of great powers.

(3) That the U.S. and China have a generally difficult relationship that might lead to expression of dissatisfaction or competition in indirect ways.

(4) That policymakers have control over the attention they give to certain areas of the world, and that this attention (or lack of it) is meaningful.

\section{$\underline{\text { Trustworthiness }}$}

Every precaution was taken to ensure material studied was timely and accurate. Whenever possible, transcripts from speeches and meetings were utilized and information was requested directly from targeted agencies. Material was kept in a secure, passwordprotected computer, and content utilized was double-checked. The survey questionnaire 
was standardized as was the method used to contact participants. All responses were kept anonymous and password-protected.

\section{Limitations}

This case study uses content analysis and elite structured surveys to discover whether the U.S. and China are in status competition over Africa. A weakness of this method is that government officials, particularly high-level ones, may very well be saying one thing in public and another in private. Gaining access to these private conversations is extremely difficult, if not impossible. Whenever possible, the researcher has tried to find other supporting data, such as policy changes, to triangulate with the content analysis.

A limitation with the surveys is that not all targeted participants were able to participate, leading to some possible gaps in information or first-hand knowledge. Another limitation is that participants may have had faulty memories, have thought one way at the time of an event and then later changed their minds, or may have hedged in answers due to concerns about preservation of anonymity.

Another limitation is in the scope of the study. In order to grasp the larger picture, country-level data was not used. This big-picture view may be contradicted or confirmed by some on-the-ground details not included in this study. Finally, the researcher has chosen not to research Chinese motivations for their activities in Africa, nor their own status concerns or beliefs about U.S. activities, in great detail. 


\section{CHAPTER FOUR: THE U.S. - CHINA RELATIONSHIP}

\section{$\underline{\text { Introduction }}$}

The first observable outcome to arise from this research study is that, as China has risen and become more powerful economically and militarily within an interdependent international system, it has expanded into a territory, Africa, that has been undervalued by the most powerful state in the system, the U.S. The U.S. initially seemed to ignore the consequences of this expansion, due to a number of factors, but in particular to its own relationships to China and Africa, which will be examined in this and the next chapter.

This chapter will first examine China's rise, particularly in the light of powertransition theory’s predictions. China's outreach into Africa in the post-Cold War era will then be examined, followed by implications of these activities for the U.S. The American perception of itself as a strong hegemon, which may have impacted its view of Chinese activities in Africa, will be examined. Particular attention will be paid to the U.S. reaction to China's rise, including its concern with concrete elements like military threat and economic impact.

\section{Power-Transition Theory's Predictions}

As shown in Chapter Two, Literature Review, power-transition theory predicts that rising states are revisionist, intent on overtaking the status quo hegemon, normally through war. They are revisionist as they were weak when the rules of the international system were created; these states would like to rewrite the rules to benefit themselves. The possibility of war looms over the situation, making the dominant state wary and more likely to attempt 
to appease the rising state. ${ }^{9}$ Power-transition theory was proposed before the end of the Cold War, when economic interdependence and norms against great power war were still growing. In particular, very strong economic links with China were not evident until China's accession to the World Trade Organization in 2001 (Wang, 2010), and during the Cold War period, there seemed a moderate likelihood that great powers - the U.S. and Soviet Union - would indeed go to war. ${ }^{10}$ The nuclear threat is a variable that has become less likely since the end of the Cold War, although China's military modernization, which includes its nuclear arsenal, is a relatively new development. ${ }^{11}$

All of these system conditions affect the predictions of power-transition theory. The rising state may well be revisionist, but if it is inextricably linked to the hegemon through its economy, as China is to the U.S., is it likely to attempt war? ${ }^{12}$ This may be selfdefeating. ${ }^{13}$ Likewise, is the rising state likely to pursue war if the system has strong norms

\footnotetext{
${ }^{9}$ See Chan (2008), Thucydides, Translated by Sir Richard Livingstone (1960), Gilpin (1981) and Organski \& Kugler (1980).

${ }^{10}$ See also Tucker (2008) for a comprehensive overview.

${ }^{11}$ See U.S. Department of Defense annual reports on China's military modernization from 2000 - 2015, and its Quadrennial Defense Reviews for 2001, 2006, 2010 and 2014 at http://archive.defense.gov/.

${ }^{12}$ According to the U.S. Trade Representative (2014), trade of goods and services between the U.S. and China was $\$ 579$ billion in 2012, and the U.S. trade deficit was $\$ 298$ billion in 2012. U.S. FDI in China was $\$ 51.4$ billion in 2012, centered in manufacturing, wholesale trade, banking and finance/insurance. China's FDI in the U.S. was $\$ 5.2$ billion in 2012, centered in banking and wholesale trade. The 2014 annual exports to China were $\$ 123,675,000,000$ and imports from China were $\$ 466,754,000,000$, creating a trade imbalance of $-\$ 343,078,000,000$ (U.S. Census, 2015). According to U.S. trade data, total trade between the two countries grew from $\$ 5$ billion in 1980 to $\$ 592$ billion in 2014. China is currently the United States' secondlargest trading partner, its third-largest export market, and its largest source of imports” (Morrison, 2015, p. 1). Chinese exports and imports have seen massive increases in scale since 1979, making it a giant trading partner in the international system (p. 20). See also Rosecrance and Gu's (2009) discussion of "deep and multifarious ties" and "MADE."
}

${ }^{13}$ See also neoliberal institutionalist works by Keohane (1984), Snidal (1991) and Keohane \& Nye (2001). 
against this kind of action? ${ }^{14}$ It would likely be crushed not only by the hegemon but also by other states in the system acting out of fear that a deeply-held norm might be violated. The rising state's nuclear arsenal might give it more power should it indeed decide to go to war, but in China's case, the relative weakness of the arsenal means it is really of little help. Because the likelihood of war has dramatically fallen due to these factors, it is also unlikely that the hegemon will feel the need to appease the rising state.

Therefore, power-transition theory should be updated to account for these new international system conditions, one of the purposes of this study. It now appears likely that a rising state which has economic links to the hegemon, and which exists within a strong web of norms restricting great power and nuclear war, will not declare war on the hegemon, no matter how dissatisfied it becomes with the status quo. We should not expect to see war between the U.S. and China. However, this does not mean that a rising state will have no impact on the hegemon. The next few sections will briefly detail China's rise and the U.S. reaction to it.

\section{China's Rise}

\section{The Economic Realm}

China's rise, from a relatively weak, low-income, isolated state to one that cannot be ignored on the international stage, has been astonishing. Morrison (2015) has given an excellent overview of China's economic rise. The Reforms of 1979 and others that

\footnotetext{
${ }^{14}$ See Christopher Fettweis (2010) for a discussion of the "obsolescence-of-major-war" idea, where war is a social construction that can be eliminated (p. 21). Fettweis argues for "zones of peace" and "zones of turmoil," effectively creating two worlds - one of peacefulness for great powers and one of instability and conflict for still-developing countries. See also Rapkin \& Thompson (2013), Kegley Jr. \& Raymond (1994), Katzenstein (1996), Krasner (1983), Hasenclever, Mayer \& Volker Rittberger (2000), and Finnemore \& Sikkink (1998).
} 
followed led to a doubling of the Chinese economy every eight years. ${ }^{15}$ During that time, China's economy experienced an average growth rate of nearly $10 \%$, slowed only by the 2008 recession. ${ }^{16}$ Growth has been fueled by massive capital investment, productivity gains by reallocation to more efficient sectors, and brisk productivity growth (p. 7), with a major competitive advantage coming from its massive population and low wages, although wages have recently been rising (p. 12). Foreign direct investment has also been a boon, with nearly half a million foreign-invested enterprises registered in China in 2010, employing $15.9 \%$ of the urban workforce. According to the United Nations, annual FDI to China rose to $\$ 128$ billion in 2014, making it the top FDI destination (Morrison, p. 13).

China's meteoric rise has led to a number of activities in the international system, including the formation of the New Development Bank (NDB) with BRICS countries, and of the Asian Infrastructure Investment Bank (AIIB), activity in regional partnerships, the creation of the Silk Road Belt and Maritime Silk Road Belt, and a certain stifling of U.S. capacity to conduct trade as seen in debate over the Trans-Pacific Partnership (TPP) (Morrison, 2015, p. 2). Further, China has been ranked first in manufacturing, pushing the U.S. down to third (p. 11). Its “Go Global” strategy of 2000 encouraged Chinese businesses (mostly state-owned enterprises, or SOEs) to invest overseas, often gaining access to natural resources to fuel growth at home. ${ }^{17}$

\footnotetext{
${ }^{15}$ These included the ability for farmers to sell their goods in the free market, the creation of special economic zones, a focus on exports, and imports of technology products. Other reforms followed, including decentralization of economic policy to local governments, elimination of price controls, trade liberalization, and support for entrepreneurship (Morrison, p. 4-5).

${ }^{16}$ The recession caused China's GDP growth to fall from $14.2 \%$ in 2007 to $9.6 \%$ in 2008, and again to 9.2\% in 2009. China utilized an economic stimulus package to control the economic slowdown. (Morrison, p. 5).

${ }^{17}$ A primary goal was to invest its foreign exchange reserves through the China Investment Corporation (CIC). Another goal, of particular interest to this case study, was to obtain access to natural resources to fuel
} 
China does face challenges in continuing its rise, including weak banking, pollution, lack of rule of law, a transition to a consumer economy and inefficiencies from state-owned enterprises. In March 2007, Chinese Premier Wen Jiabao stated that there were "structural problems in China's economy," calling it "unsteady... unbalanced... and unsustainable." Solutions in the last two five-year plans have emphasized consumer demand, income equality, energy efficiency, rule of law and economic reforms (Morrison, p. 1-7, 34-35).

\section{Soft Power}

China has sought to expand its soft power in the international system in a concerted "charm offensive." 18 One method of doing this, particularly noticeable in Africa, has involved the use of economic goods, like aid, grants, loans, investments, and other deals to gain access and win over government leaders of other states (Liang, 2012, p. 669). "Peopleto-people diplomacy” has been used to supplement economic activities. ${ }^{19}$ China has also used soft power to counter accusations that it is a threat. ${ }^{20}$ Issues for China in implementing soft power include efficacy, symbolism versus in-depth relationships, and issues with dissatisfaction among its domestic population on overseas spending (Congressional

economic growth at home. Finally, a third goal was to invest in foreign businesses in order to improve Chinese brands (Morrison, 2015, p. 7).

\footnotetext{
${ }^{18}$ See also Wang, J. (2011), Li, M. (2009), Hartig (2015), Ilgen (2006), Kurlantzick (2007), Ding (2008), and Nye (1990).

${ }^{19}$ Chinese NGOs are often involved in this effort. Examples include the "Year of China" taking place in South Africa as a precursor to the 2015 FOCAC meeting.

${ }^{20}$ China has used phrases such as "peaceful rise," "responsible power," "harmonious world," and "good neighbor policy" to calm fears. See also Liang, W. (2012), Wang, J. (2011), Li, M. (2009), Guo \& Teng (2011), Shirk (2007), Meredith (2008). See also China’s U.N. General Assembly speeches (Li Zhaoxing 9/27/04, Wen Jiabao 9/23/2010, Wang Yi 9/27/13, Xi Jinping 9/28/15).
} 
Research Service, 2008). China acknowledges deficiencies in its soft power in Africa, attributing them to "ancient Chinese culture's lack of modern applications, China's weakness in shaping international norms and discourse, different political values, and the lack of public diplomacy” (Yun, 2015). However, China’s popularity on the continent has dramatically increased, while American popularity has fallen (Center for Public Diplomacy Blog, 2012).

\section{Energy}

China has a driving need for resources. Its energy demands stem not just from a large population with rising ambitions, but also from the manufacture of steel and metals (Strategic Overview, p. 5-6). Fueling its economy is vital not only for continued growth but for the survival of the Communist Party (Zhao, 2011). In 1993, it became a net importer of oil and in 2003, it overtook Japan as the second-largest consumer of oil, behind the U.S. It will likely become the world's biggest oil consumer by the 2030s (Alessi \& Xu, 2015). From 1978 to 2000, China’s energy demand grew by 4\% per year, and since 2001, it has grown by 13\% per year. In 2003 - 04, China experienced electricity shortages which made evident bureaucratic deficiencies, and ultimately resulted in the creation of the Energy Leading Group in 2005 (Downs, 2006). The International Energy Agency (IEA) announced in 2010 that China had surpassed the U.S. to become the world's biggest energy user (Zhao, 2011).

\section{The Military}

According to the Correlates of War database (Singer, et al., 1972), China's military expenditures have risen sharply since 1979, as seen in Figure 1 below. 
Figure 1: China's Military Expenditures, 1978 - 2006

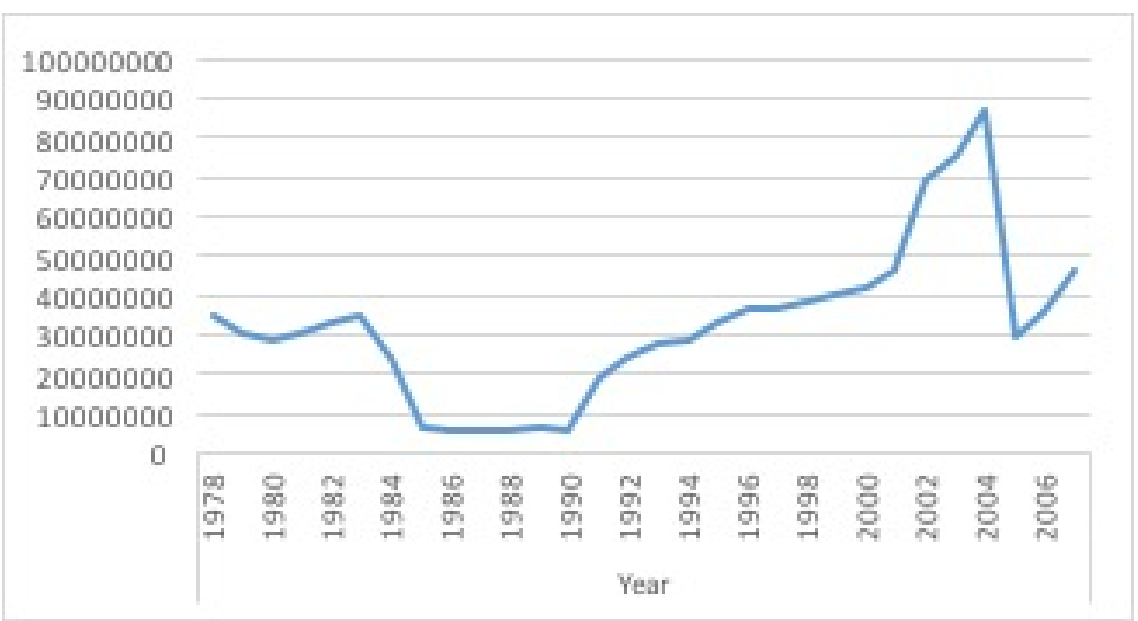

Source: Correlates of War database, Singer et al.

Military Balance, which measures the military capabilities of 171 countries, found that China has been responsible for much of the defense spending in the Asian region, accounting for $28 \%$ of the total in 2010 , and $38 \%$ in 2014. It is predicted that China will account for 41\% of Asia's regional defense spending by 2019 (International Institute for Strategic Studies (IIIS), 2015). Its spending increase of 12.2\% in 2014 was higher than in previous years (10.7\% in 2013 and 8\% in 2012) (IIIS, 2015, p. 215). ${ }^{21}$ Further, China is currently making an effort to amass foreign technologies, improve its own R\&D, and modernize its current systems. The People's Liberation Army Navy plans to mass produce destroyers, frigates and corvettes to patrol its surrounding waters (IIIS, 2015, p. 213).

${ }^{21}$ Official figures are believed to leave out spending on the People’s Armed Police (PAP) and certain science, technology and innovation funding (IIIS, p. 215). 
Along with France, Russia, the United Kingdom and the U.S., China is recognized as legitimately possessing nuclear weapons under the Non-Proliferation of Nuclear Weapons Treaty (NPT). These states promised in 2000 to work toward eliminating their entire arsenals (Arms Control, 2015). Although China's arsenal is small (about 250 warheads), it has made recent efforts to upgrade delivery systems to improve retaliation capability. ${ }^{22}$ This decision - to focus on deterrence of attacks rather than on first strike capability - reflects the overwhelming nuclear capabilities of the U.S. and Russia. Analysts do not believe that China will attempt nuclear parity (Union of Concerned Scientists, 2011). The U.S. has been tracking China's military modernization closely since 2000, when the Department of Defense was ordered to produce an annual special report on the subject. See the section below, Military, under U.S. Perceptions of China's Rise.

\section{$\underline{\text { Ranking The U.S. And China }}$}

In describing China’s rise, especially in comparison to the U.S., it is important to look at how national power is measured. ${ }^{23}$ According to the 2011 National Power Ranking, the latest data available show the U.S. and China are currently ranked very closely in several categories. In national power and diplomacy, the U.S. is first, China second. In the economy, China is first, U.S. second. Other rankings show a distance between the two. In military power, the U.S. is first and China is fourth and in technology the U.S. is first and China is sixth. Table 2, below, shows these rankings.

\footnotetext{
22 According to the Arms Control Association (2015), China has about 250 total warheads, compared to Russia's 1,582 deployed warheads and the U.S.'s 1,597 deployed warheads. France has 300 total warheads, and the UK has 40 deployed. China is not bound by the New START Treaty and the Intermediate-Range Nuclear Forces (INF) Treaty, as Russia and the U.S. are (Mahnken, 2012).

${ }^{23}$ See also Tellis, et al. (2000).
} 
Table 2: U.S. And China Rankings

\begin{tabular}{|c|c|c|c|c|c|c|}
\hline & $\begin{array}{c}\text { National } \\
\text { Power }\end{array}$ & Economy & Military & Diplomacy & Technology & Popularity \\
\hline U.S. & $\# 1(0.094)$ & $\# 2(0.867)$ & $\# 1(0.947)$ & $\# 1(0.991)$ & $\# 1(0.958)$ & $\# 5(0.742)$ \\
\hline China & $\# 2(0.854)$ & $\# 1(0.887)$ & $\# 4(0.828)$ & $\# 2(0.963)$ & $\# 6(0.888)$ & $\# 7(0.691)$ \\
\hline
\end{tabular}

According to The 2011 National Power Ranking

According to another measure, the Index of National Power (2015), the U.S. is first in power, and China is fourth, with Japan and Germany between the two. This index places importance on the relative distance between states. Finally, according to the National Power Index, as shown in Table 3, the U.S. and China again rank very closely. ${ }^{24}$

\footnotetext{
${ }^{24}$ See Appendix for information on how the National Power Index (NPI) and Quality of Life Index (QLI) are calculated.
} 
Table 3: 2010 \& 2011 National Power Index Relative Ranking

\begin{tabular}{|c|c|c|c|c|c|c|c|c|c|}
\hline & $\begin{array}{c}\text { Quality } \\
\text { \& } \\
\text { Power } \\
\text { Index 25 }\end{array}$ & $\begin{array}{c}\text { Quality } \\
\text { of Life } \\
\text { Index }\end{array}$ & $\begin{array}{c}\text { National } \\
\text { Power } \\
\text { Index }\end{array}$ & Health & $\begin{array}{c}\text { Edu- } \\
\text { cation }\end{array}$ & Wealth & Peace & $\begin{array}{c}\text { Environ- } \\
\text { ment }\end{array}$ \\
\hline U.S. & 1 & 33 & 1 & 39 & 24 & 17 & 77 & 38 \\
\hline China & 24 & 91 & 2 & 67 & 80 & 79 & 69 & 97 \\
\hline & 2 & 31 & 1 & 39 & 22 & 20 & 81 & 52 \\
\hline U.S. & 22 & 91 & 2 & 68 & 84 & 80 & 77 & 102 \\
\hline China & 22 & & & & & & & & \\
\hline
\end{tabular}

However, Eric Chiu and Thomas Willett (2012) argued that the usual measures of national power are not as explanatory today, due to increasing technology, which lengthens the amount of time needed to convert economic resources into military resources, and the weakening role of military power due to new norms (p. 5). This refers back to the earlier discussion of the current state of the international system. Further, the ability of a country to properly use its resources depends on the capacity of the government to direct them into the carrying out of desired policies (p. 6-7). This is partly reliant on complexity of bureaucracy, level of corruption and strength of rule of law.

\footnotetext{
${ }^{25}$ The Quality and Power Index (QPI) is the geometric mean of the Quality of Life Index (QL) and the National Power Index (NPI).
} 
While China is authoritarian, the government is continuously worried about popular instability, and so engages in policies meant to stave off current problems, rather than to add to overall strength or growth. Large international reserves, which China does hold, may help it, by providing a "war chest" or hinder it, by creating dependency on a state where it has invested those reserves. Exports may or may not be a strength for a nation, as dependence on them leave it vulnerable to external economic shocks. Imports may be a better indicator of strength (Chiu and Willett, p. 6-13).

\section{The American Perception of China's Rise}

In the post-Cold War period, U.S. leaders appear to have perceived China's rise as particularly threatening in the core areas of military affairs, the economy and democracy (often expressed as accusations of human rights violations). ${ }^{26}$ Outwardly, the Bush administration seemed to be putting a good face on a difficult U.S.-China relationship. After the spy plane incident (see below, Military Threats), Secretary of State Powell began calling the U.S.-China relationship alternately "the best we've ever had," and "the best relationship in 30 years," signified by a change in thinking from there was "anything inevitable about our relationship... [to] together, [we must] take responsibility for our common future” (Powell, 1/1/04, 10/14/04). In 2005, Secretary Rice called the U.S.-China relationship "candid, cooperative and constructive," built on "recognition of common interests and understanding of different values” (Rice, 1/18/05). In 2009, Secretary Rice

\footnotetext{
${ }^{26}$ See also the 2015 Pew opinion poll (“Americans' Concerns About China: Economics, Cyber-attacks, Human Rights Top the List”) which found that Americans were most concerned, in decreasing order of importance, about American debt held by China, loss of American jobs to China, cyber-attacks, China's human rights record, U.S. trade deficit with China, pollution from China, China's military expansion, and lastly, tensions between China and Taiwan.
} 
downplayed fears of a rising, competitive China, saying "No one should mind competition... the United States is going to do just fine... [China's] an influential power with which we have really excellent relations” (Rice, 1/13/09).

Yet, China’s rise did concern the Bush administration. Much emphasis was placed on China becoming “a positive force in international politics,” and whenever it cooperated on U.S. interests, such as in Darfur, Zimbabwe, Iran or North Korea, praise was heaped upon it (Rice, 7/1/08). In 2005, Deputy Secretary of State Robert Zoellick, in a speech to the National Committee on U.S.-China Relations, addressed the issue of China's rise head on. The traditional understanding of the emergence of great powers - with plenty of conflict - could be changed, he said, if China could become a "responsible stakeholder" in the current system. China should not only "adjust" but also take a seat at the table in shaping the future of that system. China need only become aware of how its actions were perceived by the world and curb its more hostile tendencies.

This showed an awareness of power-transition theory, and in particular, of the thought that a rising state must necessarily be dissatisfied with international rules and therefore revisionist. Zoellick appeared to be inviting China to leave its weak past behind and forge a stronger future - albeit one whose structure is built upon the Western international system.

The Obama Administration appears to have wanted to walk a fine line between pressure and indulgence with China (Bader, 2012, p. 2-3). ${ }^{27}$ Key strategic principles for Obama have included giving more time and attention to the Asian region, shaping China’s

\footnotetext{
${ }^{27}$ See also Assessing China’s Behavior, Berman (2011), p. 5.
} 
rise within norms and institutions, strengthening regional alliances, and addressing human rights. Secretary Clinton visited Asia, including China, on her first overseas trip, as part of an effort to "build a safety net under the relationship" (p. 19-20). In 2010, according to Bader (2012), Obama "understood there were competitive elements in [China's] relationship with the United States... but he believed the cooperative elements could and should outweigh those” (p. 69).

In 2011, Obama stated he would counter Chinese aggressiveness with counterpressure, and unveiled the pivot to Asia. ${ }^{28}$ In 2012, competition between the U.S. and China became more intense, despite leaders' efforts to "search for a 'new type of great power relationship'” that was conflict-free. The competition centered on the security dilemma created by military buildups on both sides, built on "pervasive and deeply rooted distrust" (Sutter, 2013, p. 167).

In a presidential debate, Obama called China "an adversary" which could become a "potential partner in the international community if it follows the rules" (Sutter, 2013, p. 168). This revealing statement showed that, while China may have earned a seat at the international table, it was not yet allowed to rewrite rules.

\section{China as Military Threat}

In 1994, China was accused of selling missiles and nuclear technology to Iran and Pakistan, and a Chinese cargo ship was suspected of carrying chemical weapons during the Yellow Sea/Kitty Hawk incident (Bernstein \& Munro, 1997, p. 27). China exploded a nuclear device underground in 1996, despite U.S. calls for a ban on such testing (Lampton,

\footnotetext{
${ }^{28}$ See also Campbell \& Andrews (2013).
} 
2001, p. 43). In 1995-96, missile testing in China resulted in a confrontation in the Taiwan Strait with the U.S.

In 2000, the U.S. pressured Israel to cancel the sale of an airborne early-warning system to China. In 2001, a U.S. and a Chinese fighter jet collided, killing the Chinese pilot (often called the "spy plane incident"). The downed U.S. jet was held by China for an inordinately long time, and relations became tense. The two sides were eventually able to come to an agreement. The 9/11 attacks thawed U.S.-Chinese relations, to a degree, since the U.S. needed China's help in combating terrorism (Zhao, 2008, p. 18-19). The Chinese also needed assistance with Uighur Turkish separatists in Xinjiang. Suisheng Zhao (2008) noted that the 2001 Department of Defense Quadrennial Defense Report (QDR), released just after 9/11, stated that the U.S. "took a capacity-based approach to define enemies, and believed that a 'military competitor with a formidable resource will emerge in the [Asian] region' and become a long-term threat to the United States. Although everyone knew the identification, the report did not mention the name 'China.'” (p. 16).

By 2005, the U.S. and China had cooperated on terrorism, engaged in six-party talks on North Korea's nuclear program, and made some progress on the Sudan conflict. However, Chinese military buildup was seen as a "concern," inspiring the U.S. military to increase its presence in the Asian region (Rice, 7/10/05). The 2006 QDR said: "Of the major and emerging powers, China has the greatest potential to compete militarily with the United States and field disruptive military technologies that could over time offset traditional U.S. military advantages absent U.S. counter strategies. ... Should deterrence fail, the United States would deny a hostile power its strategic and operational objectives. Shaping the choices of major and emerging powers requires a balanced approach, one that 
seeks cooperation but also creates prudent hedges against the possibility that cooperative approaches by themselves may fail to preclude future conflict” (p. 29-31).

In 2007, China shot down one of its own weather satellites in an anti-satellite missile test, the first such test since an American one in 1985, creating dangerous debris in space but demonstrating its weapons capabilities. Chinese spies were arrested in 2008, accused of espionage involving "military communications technology, arms sales and corporate trade secrets related to the space shuttle” (Washington Times, 2008). Another round of arrests was made in 2014 for cyber-espionage.

In 2010, China refused to condemn North Korea for sinking the South Korean warship Cheonan or for shelling Yeonpyeong (Tucker, 2013, p. 43). During the 2011 Obama pivot to Asia, there were "strong but disappointing efforts to build cooperation and give primacy to China in U.S. policy toward Asia” (Sutter, 2013, p. 164-166). The 2010 QDR reported that:

China is developing and fielding large numbers of advanced medium-range ballistic and cruise missiles, new attack submarines equipped with advanced weapons, increasingly capable long-range air defense systems, electronic warfare and computer network attack capabilities, advanced fighter aircraft, and counter-space systems. China has shared only limited information about the pace, scope, and ultimate aims of its military modernization programs, raising a number of legitimate questions regarding its long-term intentions (p. 31).

Several maritime incidents have occurred in China's claimed exclusive economic zone (EEZ) in the South China Sea, including harassment of the USNS Impeccable and 
USNS Victorious in 2009 and of the USS Cowpens in 2013. China also created an "Air Defense Identification Zone” in the area, which the U.S. has pointedly ignored (Starr \& Botelho, 2013). Also in 2013, China put its first aircraft carrier, the Liaoning, on exercises. In 2014, Obama proclaimed America's right to be a Pacific Power which would "insist that all nations abide by the rules of the road and resolve their territorial disputes peacefully (Obama, 2014, p. 12). "We do not want a military conflict with the United States," reads China's latest military strategy white paper "but if it were to come we have to accept it" (Blosser, 2015). The 2014 QDR put Asia front and center in the first chapter on the future security environment. ${ }^{29}$

The U.S. Department of Defense has issued an annual report on China's military since the year 2000. In 2006, the report noted that "several aspects of China's military development have surprised U.S. analysts, including the pace and scope of its strategic forces modernization." This modernization included "strategic nuclear forces modernization land- and sea-based access denial capabilities, and emerging precisionstrike weapons" with "potential to pose credible threats to modern militaries operating in the region.” Further causing consternation was China’s refusal to “explain the purposes or desired end-states of military expansion,” leaving no choice but to "hedge” (U.S. Dept. of Defense, Annual Report, 2006).

\footnotetext{
${ }^{29}$ This QDR stated: “As nations in the region continue to develop their military and security capabilities, there is greater risk that tensions over long-standing sovereignty disputes or claims to natural resources will spur disruptive competition or erupt into conflict, reversing the trends of rising regional peace, stability, and prosperity. In particular, the rapid pace and comprehensive scope of China's military modernization continues, combined with a relative lack of transparency and openness from China's leaders regarding both military capabilities and intentions” (U.S. Dept. of Defense, QDR, 2014, p. 4).
} 
In 2009, the report stated that China has called its military modernization "purely defensive in nature," although the "international community" remained unclear on "the purposes and objectives of the PLA's evolving doctrine and capabilities.” In 2013, the report found that most military spending was focused on enforcing China's abilities in the Taiwan Strait, although "as it has gained greater influence in the international system, its military modernization... [is focused] on a wider range of missions... including counterpiracy, peacekeeping, humanitarian assistance/disaster relief, and regional military operations.” The U.S. maintained it wanted military-to-military cooperation with China (U.S. Dept. of Defense, Annual Report, 2013).

\section{China as Economic Threat}

According to the U.S. Trade Representative (2014), trade of goods and services between the U.S. and China was $\$ 579$ billion in 2012, and the U.S. trade deficit was $\$ 298$ billion in 2012. U.S. FDI in China was $\$ 51.4$ billion in 2012, centered in manufacturing, wholesale trade, banking and finance/insurance. China’s FDI in the U.S. was $\$ 5.2$ billion in 2012, centered in banking and wholesale trade. The 2014 annual exports to China were $\$ 123,675,000,000$ and imports from China were $\$ 466,754,000,000$, creating a trade imbalance of $-\$ 343,078,000,000$ (U.S. Census, 2015). According to U.S. trade data, total trade between the two countries grew from $\$ 5$ billion in 1980 to $\$ 592$ billion in 2014. China is currently the United States' second-largest trading partner, its third-largest export market, and its largest source of imports” (Morrison, 2015, p. 1). Chinese exports and imports have seen massive increases in scale since 1979, making it a giant trading partner 
in the international system (p. 20). See also Rosecrance and Gu's (2009) discussion of “deep and multifarious ties" between the U.S. and China.

President Bush came into office in 2001 calling China a "strategic competitor" and generally took a firmer stance on U.S.-China policy than his predecessor. China's accession to the World Trade Organization was surrounded by difficulty, ${ }^{30}$ and Chinese copyright theft and internet censorship have become problems for the U.S. as well (Lampton, 2001, p. 16 \& 43). China has been told by the U.S. that it must be "careful" in its regional investments (e.g., Sudan). In 2004, Secretary Powell said that the Chinese "need more than anything else, a good... economic relationship with the West, and that means the United States" (Powell, 9/16/04). Communication between the two has since taken place on a government-to-government level through the annual Strategic Economic Dialogue (2006 - 2008) and the U.S.-China Strategic and Economic Dialogue (2009 - present).

Between 2000 and 2015, China filed eight complaints against the United States with the World Trade Organization. Of these, the U.S. was found to be in violation three times. During this same period, the U.S. filed sixteen disputes against China, three of which were withdrawn because of a mutually-agreed upon solution, and eight of which found China in violation of trade rules. Some of these complaints are still in consultations (World Trade Organization, 2015).

\footnotetext{
${ }^{30}$ China was asked to make a number of reforms and changes to its market system. In 1999, there was a failure to reach an agreement on terms for the accession (Lampton, 2001, p. 16).
} 


\section{China as Threat to Democracy}

It could be argued that China's political character can itself be seen as a threat to American-style democracy. Naazneen Barma and Ely Ratner (2006) defined China’s ideological challenge to the West as a combination of "illiberal capitalism" (where markets are free but politics are not) and “illiberal sovereignty” (where national borders are seen as inviolable). This challenge is stronger than any military or economic threat, they argue, since it threatens to upend the entire liberal international system. The U.S. certainly is sensitive to perceived threats to democracy and human rights violations by China, and often raises the topic in meetings and summits with them.

The 1989 Tiananmen Square crackdown on demonstrating Chinese students was arguably the most severe setback for U.S.-China relations. The U.S. and China have engaged in a Human Rights Dialogue since 1990, although it was suspended between 2002 and 2008 by China after American criticism of its violations. The U.S. generally brings issues of rule of law, freedom of expression and religion, ethnic rights, and labor laws to the dialogue. In 1993 President Clinton attempted but failed to link China’s most-favored nation (MFN) trade status with the U.S. to human rights violations (Bacevich, 2002, p. 9394). In 2005, as mentioned earlier in this chapter, Deputy Secretary of State Zoellick called on China to be a "responsible stakeholder" in the international system, essentially asking it to accept and build up the existing liberal order. In 2006, Secretary Rice said that the U.S. had worked to integrate China into the global system, and that, while the U.S. and China had differences, "cultural determinism" should not be applied to call China “inherently despotic” because of its values (Rice, 9/27/06 \& 3/31/06). China’s repression of Tibetans has been a perennial issue between the U.S. and China. Continuing clashes 
with Tibetans resulted in almost 100 deaths by self-immolation by 2013 (BBC, 2015). President Bush met with the Dalai Lama of Tibet (seen as a separatist by China) in 2001, 2003, 2005, and 2007, and President Obama met with him in 2010, 2011, 2014 and 2015. After the 2015 meeting, the Chinese called Obama a "trouble-maker," intimating the meeting had set U.S.-China relations back (BBC China, 2015).

There have been other disagreements over human rights. In 2010, the U.S. condemned Chinese cyber-attacks, while China condemned American criticism of its internet censorship. Google ended its censorship compliance. Imprisoned dissident Liu Xiaobao received the Nobel Peace Prize, despite Chinese government protests. In 2011, Chinese artist and activist Ai Weiwei was arrested for “economic crimes,” released after two months, and billed $\$ 2.3$ million in taxes by China (BBC, 2015). In 2012, Chinese dissident Chen Guangchen fled to the U.S. Embassy and was eventually granted the right to study in the U.S.

\section{Status-Based Threats}

Of particular importance to this study is the idea that the U.S. and China are engaged in status competition, sometimes in subtle ways, and that this competition extends to a variety of engagements. This section will briefly detail areas of status-based threats between the two, including the G-20, the 2008 Beijing Olympics, the Chinese space program, and China’s recent request for “a new kind of great power relationship” with the U.S. 
Although founded in 1999, the G-20 (Group of 20) gained significance primarily after the recession of 2008. ${ }^{31}$ China, as a founding member, has "historical ownership" in the forum, key for a country that was not involved in the formation of other major institutions. Participation in the G-20 does not preclude China from continuing to call itself a developing economy. Further, it provides a way for the U.S. and China not only to negotiate their key issues, but also to bring bilateral issues into a multilateral context. China will take on the presidency of the group in 2016. The G-20 has been attempting to reform institutions like the IMF and World Bank by changing voting rules, which the U.S. has been obstructing (Jorgensen \& Strube, 2014).

The 2008 Beijing Olympics were meant to showcase a rising, benevolent China, capable of massive, rapid infrastructure creation. President Bush attended the games over domestic American and foreign protests; some called it the "Genocide Olympics.” Hosting may not have been healthy for China's long-term political freedom; however, it appears to have won at least a portion of the status it sought. ${ }^{32}$ China has gained the rights to the 2022 Winter Olympics, successfully fending off one other competitor, Kazakhstan.

As the U.S. invests less in it space program, other actors like China have expanded theirs, gaining substantial national pride and prestige in the process. In 2003, China launched its first manned spacecraft with Astronaut Yang Liwei; in 2005 it launched its second manned spacecraft; in 2007 it launched its first moon orbiter; in 2008 Astronaut Zhai Zhigang completed the first Chinese spacewalk; in 2012 it completed its first manual

\footnotetext{
${ }^{31}$ See also Obama (9/23/10 and 9/25/12).

32 See Taylor (2013), Sify Sports (2008), d'Hooghe (2014) and the U.N. General Assembly speeches by Xi Jinping (9/28/15) and Wen Jiabao (9/24/08).
} 
docking; and in 2013 it landed rover Yutu on the moon. China plans to have a space station by 2020 (Brennan, 2015).

In 2012, China began to put forth the idea of "a new kind of great power relationship" between the U.S. and China. ${ }^{33}$ This phrase was brought out at bilateral meetings and fora, such as the U.S.-China Strategic \& Economic Dialogue by Hu Jintao and Xi Jinping. The meaning for China centers on respect for each side's core interests. This might translate, for instance, into Chinese support for U.S. policies on the Middle East and terrorism, in return for U.S. support on China's territorial claims in the South China Sea. Although the U.S. initially showed some acceptance of this idea, China's launch of its Air Defense Identification Zone seems to have caused the U.S. to back away from the idea. Instead, the U.S. has deferred to traditional U.S. talk about "cooperation" and “management of differences” (Akita, 2014).

Interviewees were reluctant to characterize the U.S.-China relationship as overtly negative. Respondent D said there is a "growing official recognition in both countries of mutual interdependence, accompanied by general suspicion by some in both capitals of the others intentions, and inevitably some differences of interest.” This echoes the outcomes found in this chapter, particularly the tensions between the U.S. and China over "a new type of great power relationship" and the areas of concern for the U.S. (military, economic and status-based threats). Respondent C said that the relationship has evolved and that China now competes for the position of greatest nation. Certainly tension appears to exist

\footnotetext{
${ }^{33}$ See Cheng (2013) and Wertime (2015).
} 
in this arena, particularly as the U.S. has strongly felt and defended its hegemonic position, and as China has risen in power and status in the international system.

\section{China’s Expansion into Africa}

China was a marginalized player in the Cold War, and its interest in Africa waxed and waned during the 1970s and 1980s. True growth in the relationship began in the 1990s. China has engaged with Africa in a different way than the West, touting itself as the leader of the Third World, the only Southern country with a seat on the U.N. Security Council, and fully able to understand Africa's difficulties as a recently developing country itself (China’s Approach, 2005).

There are a host of reasons ${ }^{34}$ why China has ramped up its activity in Africa, especially from the 1990s on, including isolation after its Tiananmen Square crackdown, expanding Chinese trade, desire for voting support in the United Nations, fending off Western human rights agendas, isolating Taiwan, looking for new markets for its goods and natural resources, ${ }^{35}$ seeking a way to demonstrate strength as a global actor and to combat perceived American hegemony, using up foreign exchange reserves, exploiting African agriculture, expanding Chinese tourism, and circumventing textile manufacturing rules. $^{36}$

\footnotetext{
${ }^{34}$ See also Taylor (2004), Alden (2005), Carmody \& Owusu (2007), Brautigam (2009), and Executive Research Associates (2009).

${ }^{35}$ See also Zweig \& Bi (2005).

${ }^{36}$ See also U.N. General Assembly speeches that mention Africa, South-South support, and economic support and debt relief for African countries, including Li Zhaoxing (9/27/04), Hu Jintao (9/23/09), and Yang Jiechi $(9 / 28 / 11)$.
} 
China appears to believe that Africa will be playing a greater role internationally and is a key space to stake out, particularly as a kind of "South-South counter-hegemonic strategy” against the West (Taylor, 2004, p. 93-94). Eisenman and Kurlantzick (2006) identified a rising sophistication among Chinese leaders, scholars and domestic public, which led to a self-perception of China as a global actor, perhaps causing China to be more proactive in areas like Africa. Howard French (2014) quoted a local African likening China's patience to that of a boa stalking its prey: "the Chinese are waiting for a long-term return... a maximal result” (p. 176).

China has some competitive advantages over Western countries, and has provided an alternative to Western conditionalities. ${ }^{37}$ China has questioned Western insistence on democracy in Africa as a precursor to development. The "marriage" between China and Africa has given rise to a number of "fruits," including a rise in African exports to China, ${ }^{38}$ fulfillment of unmet consumer demands in Africa, availability of business credit, and a new interest in African resources and markets (Congressional Research Service, 2008, p. 107). China has cited its non-interference policy as grounds for working with "rogue" governments, although some believe on-the-ground realities are pushing China away from this position (Alessi \& Xu, 2015). African leaders have generally defended their right to work with China, ${ }^{39}$ despite Western displeasure. China has defended itself against charges

\footnotetext{
${ }^{37}$ See also Kurlantzick (2007), Campbell (2008), Beuret \& Michel (2009), and He (2010).

${ }^{38}$ According to Paulo Drummond and Estelle Xue Liu of the IMF (2013), Africa's exports to China have increased from \$6 billion U.S. in 2003 to \$59 billion U.S. in 2012.

${ }^{39}$ See Kufuor (2/20/08) and Zuma (6/29/13).
} 
of neo-colonialism, ${ }^{40}$ lack of transparency, ${ }^{41}$ and its dealings with non-democratic regimes. ${ }^{42}$ Jon Walker (2008) claimed that China's activities reflect its general foreign policy objectives, including maintaining an international environment that allows economic reform and modernization, assuring regional neighbors of its peaceful intentions, countering U.S. influence by building bilateral relationships, accessing natural resources and denying Taiwan international support (p. 3). These objectives are thus pro-China and not meant to be anti-U.S.

\section{China's Diplomatic Activities}

China purposefully engages African countries through public diplomacy, summits and an upgraded diplomatic corps (Kurlantzick, 2007, p 58-64). According to Ambassador David Shinn (2005), "in 2005 alone, China sent twice as many cabinet level officials to Africa as did the United States or France” (China's Approach, p. 9). Through this “corporate engagement strategy,” high-level Chinese leaders and diplomats woo Africans through “prestige diplomacy,” economic help and diplomatic support. China’s state-owned enterprises have been encouraged to expand into Africa, and their deals are generally tied to the use of Chinese labor or the purchase of Chinese goods, dubbed "One China” (Gill \& Reilly, 2007, p. 38). In 2012, the new African Union headquarters in Addis Ababa, Ethiopia, funded entirely by China at a cost of \$200 million, was unveiled (BBC Africa, 2012).

\footnotetext{
${ }^{40}$ See Becker (2010), French (2014, p. 192) and Reuters (2015).

${ }^{41}$ See Congressional Research Service (2008).

${ }^{42}$ See Brookes \& Shin (2006) and Alessi \& Hanson (2012).
} 
To facilitate its interests in Africa, China created the Forum on China-Africa Cooperation (FOCAC) in 2000, as well as the Program for China-Africa Cooperation in Economic and Social Development (Kurlantzick, 2007, p 48-49). The China-Africa Think Tanks Forum began in $2011 .{ }^{43}$ FOCAC meets triennially, alternating between China and various African locales, and generally consisting of proclaiming Chinese initiatives and achievements and signing contracts.

At the first FOCAC meeting, African leaders were presented with an array of attractive promises, designed to compete with those of Western countries. ${ }^{44}$ FOCAC meetings since then have continued to lay out a variety of benefits ${ }^{45}$ to Africans, and China has mentioned them several times in U.N. General Assembly speeches. ${ }^{46}$ The next meeting is scheduled to be held in December 2015 in South Africa. Further, reciprocal visits at the head of state and lower levels are made and legislative bodies exchange information. (Committee on Foreign Relations, 2008, p. 108-118).

FOCAC has focused on "the recognition of "non-interference" as the cornerstone of bilateral relations between countries, and on dealing with radical Islamism, debt relief, reductions in tariff barriers, immigration, peace-keeping missions and challenging the Washington Consensus” (Strategic Overview, p. 8). FOCAC meetings are designed to

\footnotetext{
${ }^{43}$ See http://www.focac.org/eng/xsjl/xzhd/t894943.htm and Yun (2015).

${ }^{44}$ These benefits have included targeted debt relief, peacekeeping in African conflict zones, cheap loans for infrastructure, political junkets for African leaders to Beijing, support for African nations in the United Nations, World Trade Organization, International Monetary Fund and World Bank, military deals, noninterference in African political affairs, the promotion of South-South links, and the establishment of parallel development (Executive Research Associates, p. 12).

${ }^{45}$ See http://www.focac.org/eng/ for details on each summit's outcome.

${ }^{46}$ See Li Zhaoxing (9/19/05 and 9/22/06).
} 
showcase the "Five Principles of Peaceful Coexistence," which guide Chinese foreign policy (Executive Research Associates, p. 12). These principles are: "mutual respect for sovereignty and territorial integrity, mutual non-aggression, non-interference in each other's internal affairs, equality and mutual benefit, and peaceful coexistence” (China Daily, 2015).

\section{China's Economic and Aid Activities}

China provides "no-strings attached" assistance ${ }^{47}$ that often includes a mixture of aid, investment and trade, not easily separated, plus special economic zones. ${ }^{48}$ Chinese aid ${ }^{49}$ tends to focus on infrastructure, ${ }^{50}$ in contrast to Western donors. One of China’s main purposes appears to be to gain access to African natural resources. ${ }^{51}$ Africa is also an excellent market for China: in 2009, China eclipsed the U.S. as the top trading partner for Africa. In 2010 Sino-African trade was $\$ 126.9$ billion and \$200 billion in 2013 (Alessi \&

\footnotetext{
${ }^{47}$ See Taylor (2004) and He (2010).
}

${ }^{48}$ This is sometimes called the "Angola Model" and often consists of low-interest loans to countries that have bad credit ratings, in return for natural resources rights (Alessi \& Xu, 2015).

${ }^{49}$ China has worked with the African Development Bank, and has also created and capitalized the ChinaAfrica Development Fund. China's Export-Import Bank works extensively with aid/investment packages, as well, along with its Ministry of Commerce and China Development Bank. China is a member of the West African Development Bank and has agreements with the East African Development Bank and the Eastern and Southern African Trade and Development Bank (Congressional Research Service, 2008, p. 108-111). China has been working with the African Union in a limited manner, and has provided rhetorical support for the New Partnership for Africa's Development.

${ }^{50}$ This can lead to a range of problems. See Gatsiounis (2012).

${ }^{51}$ In 2013, China imported 1.3 million barrels per day from Africa, or 23\% of oil imports. Major African suppliers are Angola, Equatorial Guinea, Nigeria. The Republic of Congo, and Sudan. Other natural resources imported from Africa include iron ore, metals, other commodities and smaller amounts of food/agricultural products (Alessi \& Xu, 2015). 
$\mathrm{Xu}, 2015)$. Projects total in the billions. ${ }^{52}$ Table 4 and Figure 2 below show total estimated aid flows from China to African countries by year, continent-wide, collected by AidData.org, which has developed a methodology for tracking official and unofficial Chinese aid.

Table 4: China's Aid to The African Continent, 2000 - 2012

\begin{tabular}{|l|c|}
\hline Year & Total Aid, in Current U.S. Dollars \\
\hline 2000 & $\$ 2,190,011,496.04$ \\
\hline 2001 & $\$ 1,014,910,093.04$ \\
\hline 2002 & $\$ 1,231,813,362.38$ \\
\hline 2003 & $\$ 2,405,278,003.48$ \\
\hline 2004 & $\$ 3,222,543,963.71$ \\
\hline 2005 & $\$ 2,713,790,420.3$ \\
\hline 2006 & $\$ 7,634,262,955.86$ \\
\hline 2007 & $\$ 14,910,811,513.21$ \\
\hline 2008 & $\$ 5,079,065,938.27$ \\
\hline 2009 & $\$ 18,820,495,319.35$ \\
\hline 2010 & $\$ 22,285,743,111.91$ \\
\hline 2011 & $\$ 13,389,261,973.7$ \\
\hline 2012 & $\$ 21,020,541,177.93$ \\
\hline
\end{tabular}

52 See The Mail \& Guardian Africa (9/19/2015). 
Figure 2: China’s Aid to The African Continent, 2000 - 2012

\section{In Current U.S. Dollars}

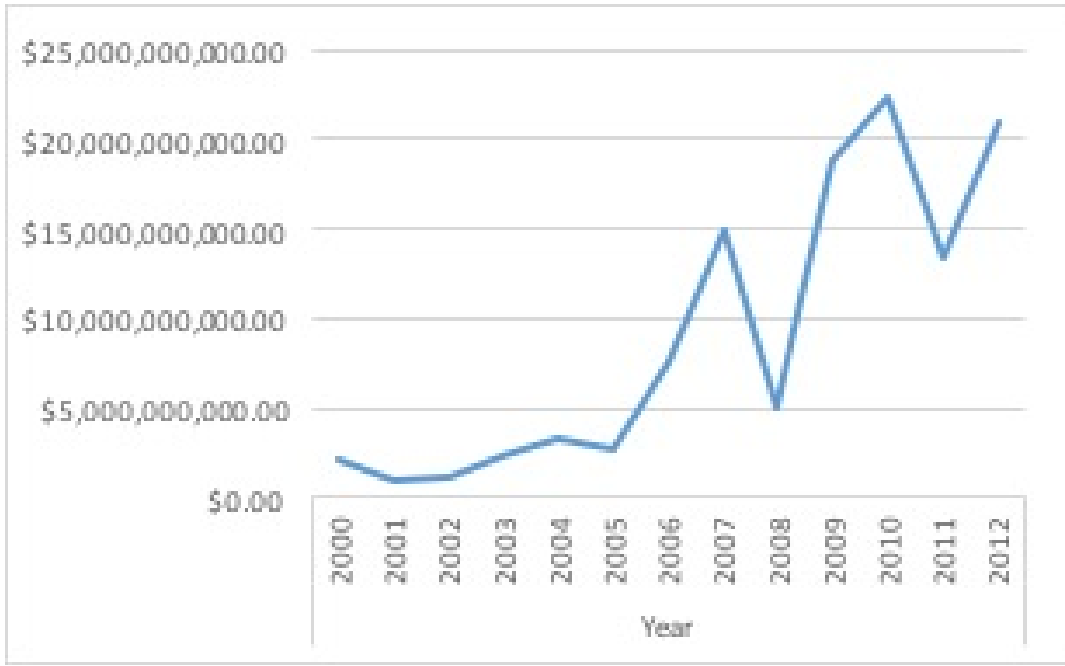

Source: AidData.Org

China’s Military Activities

Chinese military aid has been offered to Africa in a limited manner; China is better known for selling arms in Africa (Congressional Research Service, 2008, p. 112). In terms of shares of the total volume of exports of major conventional arms to sub-Saharan Africa, China has moved from fourth overall, with a share of $6 \%$ between 1996-2000, to first overall, with a share of 25\%, between 2006-2010 (Wezeman, et al, 2011, p. 10). According to Pieter Wezemann of the Stockholm International Peace Research Institute (SIPRI) (2015), China has been involved in selling "low end” equipment, including armored vehicles and simple combat airplanes. African countries involved in purchases include Sudan, Nigeria, Tanzania, Namibia, Cameroon, Morocco and Algeria. China generally does abide by United Nations arms embargoes. 
China's peacekeeping activities in Africa have been rapidly expanding, and today it has contributed the greatest number of peacekeepers $(2,000+)$ of the UN Security Council members, 1,800 of whom are in Africa, and has taken in part in more than 16 missions, including counter-piracy in the Gulf of Aden. China pledged to send military troops to Sudan in 2015 (AllAfrica.com, 2015).

\section{Implications for The U.S.}

Padraig Carmody and Francis Owusu (2007) claimed that, while the U.S. attempts to "embed, constrain, legitimate, enable and empower African states along different dimensions," the Chinese simply want to "enable and empower them," meaning they will go where the West does not deign to. Some African states, which once bandwagoned with the U.S. (after the 9/11 attacks, especially), are now attempting to balance against it using China's weight. In fact, many authoritarian African states benefit from China's presence, which the U.S. worries will lead to additional destabilization (p. 512-514). Even more worrisome, China's actions as a global actor are not limited to rogue regimes, the Committee on Foreign Relations (2008) notes. Rather, "PRC outreach also has extended to key U.S. allies or to regions where U.S. dominance to date has been unparalleled and unquestioned, leading some to conclude that Beijing ultimately intends a direct challenge to U.S. global power” (p. 4).

Interviewees were very aware of the kinds of activities China has been carrying out in Africa. Respondent A said "China tends to offer African governments infrastructure projects (roads, bridges, government buildings) built by Chinese workers. The new A.U. commission HQ in Addis Ababa is a good example. China’s interest appears to be solely 
focused on its own needs - and not necessarily the long-term development needs of the host government.” Respondent B said that China "is engaged with very skilled diplomats.” Respondent C said "China is not concerned about governance or diplomacy. They position themselves as partners who can put their skills and comparative advantage at the disposal of African countries in exchange for resources." Respondent D said, "China has quite noticeably increased the quality of its diplomatic representation in Africa, reinforced by a considerable investment in personal attention and time through visits and senior-level meetings, including summits. As well, China has certainly engaged in major 'loans' or other forms of financial or development support to achieve specific objectives in individual countries or regions.”

Most respondents had noticed China carrying out large-scale infrastructure projects, and had seen an emphasis on natural resources and trade. Respondent $\mathrm{C}$ said China’s trade and commerce activity was "surging.” Respondent D said, “China has been aggressively pursuing commercial and economic interests in much of Africa, especially access to key minerals or other resources. This period has seen a significant improvement in the quality of China's diplomatic representation in Africa [such as Chiefs of Mission being fluent in national working languages, like English or French]... All of this, however, has also been accompanied by some growing signs of divergent interests, at least selectively, between Chinese official policies and goals and those of Chinese private commercial enterprises.”

While one respondent found U.S. methods in Africa to be similar to the Chinese, other respondents saw major differences. Respondent A said "the U.S. is focused on partnership, building strong relationships with the African governments and working on 
joint priorities." Respondent C said "the U.S. positions itself more as a developing partner who puts conditionalities to negotiate and disburse aid.” Respondent D noted the following differences: "continuing strong emphasis by the U.S. in human rights, democracy, and general 'governance' issues, often viewed as 'strings- attached' to other programs, and never a part of Chinese official activities... a greater willingness by senior Chinese officials to invest time and effort and personal contacts (e.g., visits, summits, etc.), although there has been increasing U.S. activity in this regard as well... a Chinese ability to coordinate and utilize official programs (for example, grants, development packages) combined with commercial activities (for example, mining rights and concessions) in a manner not possible for the U.S. with highly diverse private-sector based commercial activities and more restrictive 'aid' policies and programs... greater emphasis by U.S (and other Western) ODI programs of longer-term development needs versus Chinese programs.”

Respondents generally saw China's purpose as being related to access to resources. Respondent B called the China's activities mercantilist. Respondent D said:

I believe the first priority has been to ensure needed assets for Chinese economic growth, including access to strategic materials and development of export markets, and secondarily to build or strengthen political and diplomatic relations. The older seemingly overriding priority of limiting Taiwanese diplomatic influence has waned as the presence of Taiwanese representation, recognized as the Republic of China representatives, has decreased to very limited numbers... economic and commercial interests have clearly assumed a higher priority over this period. I believe very 
recently there is a growing interest in Beijing to begin to play a more significant political role, although this is still very limited relative to traditional activities by major Western powers and still firmly within China’s long-standing official policy of non-interference in internal matters of African states.

Respondents generally did not find China's activities threatening to the U.S. Respondent D said, “While China's commercial interests certainly at times directly compete with those of the U.S., I have not seen a direct conflict of strategic interests of the two countries. I would note that at times China's commercial interests have produced opposition to or blockage of U.N. Security Council or other actions backed by the U.S., for example relative to Sudan.” As will be seen in later chapters, officials were slow to recognize Chinese activities in Africa as threatening, and the respondents may have exhibited a similar tendency.

\section{$\underline{\text { Conclusion }}$}

This chapter has demonstrated the specific situation the U.S. and China have found themselves in as China has risen. China's rise, and the American self-perception of hegemony, have combined with U.S. neglect of Africa, as will be shown in the next chapter, to create fertile ground for Chinese expansion. This chapter has shown that the U.S. reaction to China's rise has tended to focus on very direct elements of the U.S.-China relationship, particularly the areas of military, the economy and democracy, which may have left the U.S. inattentive to the significance of Chinese activities in Africa. 
The next chapter will explore the second observed outcome of this research study, which is that as activities in the previously ignored and neglected global region become more evident to the hegemon, its leaders will downplay their significance, even while other officials, such as Congresspeople, sound the alarm. 


\section{CHAPTER FIVE: EARLY REACTIONS TO CHINESE ACTIVITIES IN AFRICA}

\section{Introduction}

In the previous chapter, China's rise into a particular kind of international system was detailed. China's rise, and the American self-perception of hegemony, combined with U.S. neglect of Africa to create fertile ground for Chinese expansion. The U.S. reaction to China's rise has tended to focus on very direct elements of the U.S.-China relationship, particularly the areas of military, the economy and democracy, which may have left the U.S. unaware of the significance of Chinese activities in Africa.

This chapter will explore the second observed outcome of this research study, which is that as activities in the previously ignored global region become more evident to the hegemon, its leaders downplayed their significance, even while other officials, such as members of Congress, sounded the alarm. To demonstrate this, the chapter will first examine Africa as an area of the world undervalued by the U.S. To do this, general U.S. interests in Africa will be inventoried, followed by an investigation of the ways in which the U.S. has undervalued Africa. This will include the American custom of placing value on non-economic areas in Africa, such as health, perception of corruption and an unfriendly business environment on the continent, the small percentage of African trade compared to U.S. global markets, an American domestic public historically uninterested in Africa and rampant with deeply-held, if erroneous, beliefs about the continent, and supply-side issues with African companies. 
This will be followed by a tracing of President Bush's view of Africa as in need of development aid but certainly not an economic powerhouse. Then, the chapter will parse President Obama's undervaluing of Africa up to 2011, when U.S. discourse toward Africa changed, perhaps due to recognition of status threat by China. The chapter will then examine the American understanding of Chinese activities in Africa before 2005, as well as the awareness of Chinese diplomatic summits in Africa. The split between members of Congress and other American leaders on the significance of Chinese activities in Africa will then be analyzed.

\section{The U.S.-Africa Relationship}

The American relationship with Africa in the post-Cold War era has been influenced by its historical relations with the continent, including the slave trade in the $18^{\text {th }}$ century and the proxy wars of the Cold War. Odd Westad (2005) claimed the U.S. helped create the Third World during the Cold War, by intervening and radicalizing African regimes, even those that did not favor the Soviet Union, and by oppressing them through its world economic system (p. 157). The use of Africa as a stage for the playing out of great power politics was certainly the defining feature of the relationship in recent history.

James Hentz (2004) argued that U.S. foreign policy towards Africa has been dominated by three competing master narratives: (1) realpolitik, (2) the Hamiltonian tradition of peace through economic security, and (3) Global Meliorism, which is a mission to improve the world. Hamiltonian is the default mode, with realpolitik occasionally exerting a strong influence (p. 24). 
Still, post-Cold War, the U.S. has followed a 'policy' of “benign neglect” with Africa, relying mostly on international financial institutions to create market opportunities and provide access to resources (Carmody \& Owusu, 2007, p. 515). This neglect has led to the opening of this space to domestic actors, including the media, corporations, and academics. ${ }^{53}$ Special interest groups have remarkable access in the Africa sector, turning it into "a symbolic arena for a host of pet projects” (Gordon et al., 1998, p. 78). The “CNN effect," where strong images of famine or conflict actually affect foreign policy, is another strong factor in U.S-Africa relations (Hentz, 2004, p. 26-27). Donald Rothchild (2002) has seen a downward spiral towards marginalization for Africa in the U.S. Simultaneously, globalization has narrowed desired trading partners to those well-established in the international system, and deepened distrust of those with weak rule of law (p. 215).

Howard French, in a 2015 interview, said "Make no mistake, China is competing with the United States, and an important element of that is going where its major rival, namely [the U.S.] is thinly represented on the ground, lightly engaged in terms of political, economic and policymaking resources - in other words, places where the United States has been coasting or has simply not brought its 'A Game.”' Further, French claimed, “[The U.S.] is stuck with old policy paradigms in Africa that hark back to the Clinton administration, of favoring selected autocrats who can keep order locally in their regions, and cooperate with the United States in its extra-African policy priorities, especially those related to radical Islam and the 'war on terror,' and we do so, furthermore, in the naïve

\footnotetext{
${ }^{53}$ See Gordon, Miller \& Wolpe (1998).
} 
conviction that the autocrats also offer a better chance at generating and sustaining economic growth.”

Michael Clough (1992) argued that, post-Cold War, the U.S. was engaged in a “policy of cynical disengagement,” guided by three principles: (1) spend as little money as possible unless forced to by Congress, (2) work to keep African issues from eclipsing those in other regions of the world, and (3) don't take up an African issue if it will create a domestic controversy (p. 193-198). The White House has also deferred to Africa specialists in the State Department, Pentagon and CIA, which means it is their bureaucratic missions that rise to the top of the heap (Schraeder, 1994, p. 252).

As Africa has become a more competitive landscape, and as weaknesses in U.S. policy have become more evident, the U.S. has experienced a waning of influence. This can be seen especially in the areas of diplomacy, bilateral relations, energy policy and engagement with China, over focus on terrorism and a domestic public narrowly concerned with issues like Darfur. Eisenman and Kurlantzick (2006) argued that the U.S. faces new challenges in influencing Africa, particularly since the continent has not been a priority lately outside of counterterrorism in the North and East. The U.S. has held few bilateral meetings, has cut back on energy attaches to Africa, has restricted policies on student visas and has been seen as “meddling” in local governments' affairs, which invokes a negative reaction in the average African citizen. Andrew Bacevich (2002) argued that, in the end, bringing Africa into the global market is a low priority for the U.S. because “Africa doesn’t pay" when compared with the rest of the world. "Even a major commitment to opening Africa would be unlikely to contribute much to U.S. economic well-being or American political clout - and such an effort would necessarily come at the expense of other areas 
possessing greater immediate promise... American indifference to Africa makes sense” (p. 111-112).

Racism in the minds of foreign policy makers and in the American domestic public against Africans is very rarely discussed. Nikhil Aziz (2003) argued that race and racism have been "whitewashed" out of analysis of foreign policy, in discourse surrounding it, in the mainstream media, and by actual policymakers. This is the result of structural, not individual, racism, which can be defined as "the complex ways in which historical oppression, culture, ideology, political economy, public policy and institutional practices interact to produce forms of racial sorting.” On the international level, this might be called "global apartheid," where "race determines access to basic human rights, wealth and power.” It arose from the ashes of the slave trade, colonialism, and rampant, open racism of the past. Certainly the neglect the U.S. has shown to Africa has some root in racism, although it is difficult to bring to light or to separate from other forms of corruption or conflict.

Misunderstandings among the American domestic public about how the U.S. treats Africa are reflected in overestimations of the amount of foreign aid the U.S. provides to the world (of which Africa receives a large share). In 2010, Americans believed the U.S. gave $25 \%$ of its budget to foreign aid, a result consistently found since 1995 . In fact, the U.S. spends about $1 \%$ of its budget on foreign aid (World Public Opinion, 2010). American media often neglect or downplay when the U.S. does visit or make policy updates toward 
Africa, or perpetuates stereotypes typically held by Westerners about Africa, which then likely affects the attitudes of the American public. ${ }^{54}$

\section{General U.S. Interests in Africa}

U.S. interests in Africa, which tend to be classified as important but not strategic, include proliferation of U.S. values, such as democracy and human rights, security, disease control and resource protection (although oil may eventually reach 'near-strategic proportions') (Morrison \& Cooke, 2001, p. 3). Donald Rothchild (2002) added global market integration and economic development to the list of "real but limited" interests (p. 216). The $9 / 11$ attacks created a strategic interest in fighting terrorism, while the threat of destabilization through conflict has strengthened the American focus on humanitarianism (Hentz, 2004, p. 32).

President Obama’s 2012 U.S. Strategy Toward Sub-Saharan Africa laid out current U.S. priorities through "four pillars" of U.S.-Africa policy. These pillars are: (1) strengthening democratic institutions by promoting good governance and human rights; (2) spurring economic growth, trade and investment by promoting reforms, building on current U.S. programs, improving governance, promoting regional integration, expanding African integration in the global market, especially through renewal of AGOA, and improvement of supply side constraints, encouraging U.S. companies to trade with and invest in Africa through the "Doing Business in Africa Campaign"; (3) advancing peace and security through counterterrorism, regional security reform, preventing conflict and promoting peace; and (4) promoting opportunity and development, especially through the Global

\footnotetext{
${ }^{54}$ See also Hagos (2000), Mengara (2001), Keim (2014) and Mayer (2002).
} 
Health Initiative, Feed the Future, and the Global Climate Change Initiative (White House, 2012, p 2-7).

Interviewees appeared to believe that Africa had some economic potential, which was being ignored by the U.S. Respondent A said, “Africa's potential is under appreciated by the U.S.- particularly companies who are uninformed about the opportunities.” Respondent B mentioned that seven of the ten fastest growing economies are in Africa and that U.S. exports to Africa are growing. Respondent C said, "Despite Africa's potential, the U.S. has not increased its interest or stakes in the continent. Africa is not high in the U.S. diplomatic agenda.” Respondent D said, "I would argue that Africa's economic potential in fact warrants somewhat greater attention. I believe U.S. attention levels have been hampered by the relative lack of U.S. media coverage and the general lack of knowledge of Africa in the U.S.”

The following general American interests will be discussed: oil, military \& peacekeeping, humanitarian \& development aid, and trade.

\section{$\underline{\text { Oil }}$}

James Dao wrote in 2002 that "Africa, the neglected stepchild of American diplomacy, is rising in strategic importance to Washington policy makers, and one word sums up the reason: oil." Congressional hearings about African oil ${ }^{55}$ concluded that the U.S. had a "significant” or "strategic" rising interest in the region, especially in a post-9/11 world. ${ }^{56}$ Klare (2008) noted that Africa was seen by some as a "deeply divided, politically

\footnotetext{
${ }^{55}$ See Africa’s Energy Potential, Humphrey and Royce (2000).

${ }^{56}$ See Honey (2003).
} 
weakened continent, remarkably open to international exploitation” (p. 146). Nearly all the increases in U.S. trade with Africa in recent years have come from natural resources, particularly oil (this will be explored in further detail in Trade, below).

\section{$\underline{\text { Health and Development Aid }}$}

Official development assistance (ODA) from the U.S. to sub-Saharan Africa as a whole rose from $\$ 967$ million in 1996-97 to \$8.656 billion in 2012 (figures are in 2011 dollars). The percentage of total American ODA going to sub-Saharan Africa rose from $12 \%$ to $34.6 \%$ in the same time period (OECD, 2014). While USAID, the government's foreign aid arm, does not explicitly state aid conditionalities, they are often added in the Congressional approval process. The Millennium Challenge Corporation (MCC), however, requires countries to meet certain conditions before being eligible for aid. ${ }^{57}$ The Heavily Indebted Poor Countries (HIPC) Initiative (1996) and the Multilateral Debt Relief Initiative (MDRI) (2005) for debt relief in African countries are not direct U.S. programs. ${ }^{58}$ However, debt relief certainly affects U.S.-Africa policy, not least because to qualify a country must commit to reform (International Monetary Fund, 2014). The U.S. has also offered debt relief through the Paris Club, an informal group of creditor countries that often negotiates debt restructuring (Paris Club, 2014). The problem with a strong focus on humanitarian and development aid is that, according to Bennes (2012), it "deals with

\footnotetext{
${ }^{57}$ Established in 2004 under Pres. Bush, the MCC uses the median score of 17 indicators (such as rule of law, control of corruption, civil rights, etc.) to determine whether countries are eligible for aid.

${ }^{58}$ They are administered by the IMF, World Bank and United Nations.
} 
development indirectly and reinforces the classical donor recipient/expert client relationship, instead of building genuine, equal economic partnerships.”

\section{Military and Peacekeeping}

Post-9/11, counterterrorism has become a dominant focus for the U.S. in Africa. Major operations include the Africa Contingency Operations Training \& Assistance program (ACOTA), ${ }^{59}$ International Military Education and Training (IMET) funding, ${ }^{60}$ U.S. AFRICOM, ${ }^{61}$ the Pentagon's Excess Defense Articles Program ${ }^{62}$ and contribution of peacekeepers through the African Union and the United Nations. ${ }^{63}$ Militarization of the continent is only partly about counterterrorism; oil infrastructure and shipping lanes must be kept safe (Klare, 2008, p. 148 \& 160).

Phillip Carter III (2009) believed that the U.S. had shifted from doing good for Africa, to doing good with Africa, with a major focus on security. "The goal is to develop a network of well-governed states capable through responsible sovereignty of protecting

\footnotetext{
${ }^{59}$ This program is housed within the Office of Regional and Security Affairs in the Bureau of African Affairs at the U.S. Department of State. It grew out of the 1997 Africa Crisis Response Initiative. It is designed "to enhance the capacities and capabilities of its African Partner Countries, regional institutions, and the continent's peacekeeping resources” (U.S. Department of State, 2013).

${ }^{60}$ This training is designed to beef up local militaries, as well as bring them into contact with democratic and human rights values (U.S. Department of State, IMET, 2014).

${ }^{61}$ Created in 2007, AFRICOM is a regional command center focused on the African continent. The mission is "to build defense capabilities, respond to crisis, and deter and defeat transnational threats in order to advance U.S. national interests and promote regional security, stability, and prosperity.” It was difficult for AFRICOM to find a home on the continent and it is currently stationed in Stuttgart, Germany (U.S. Africa Command, 2014).

${ }^{62}$ See the Defense Security Cooperation Agency (2015) and Klare \& Volman (2006).

${ }^{63}$ See the White House Fact Sheet on U.S. Support for Peacekeeping in Africa (2014), which details not only contributions but also the new African Peacekeeping Rapid Response Partnership, or A-Prep, designed to build African military capacity.
} 
themselves and contributing to regional security. By doing so, they also protect the international system," he said. The U.S. must help resolve conflict, and it had four priorities in doing so. First, security assistance, at the African Union, sub-regional, and state level; second, democracy, governance, transparency, and accountability, especially post-conflict; third, improve the economy and reduce barriers to trade and investment; and fourth, food security and agriculture. He further expressed the belief that the American focus on being a strategic partner to Africa, which necessarily included a focus on democracy, governance and reduction in corruption, meshed with Africa's beliefs in the power of freedom, security and the rule of law ( $\$ 150$ Oil, Carter, 2009). Focus areas have been Sudan, Darfur and Zimbabwe, ${ }^{64}$ with a more recent emphasis on terrorist groups, like Boko Haram.

While American militarization of the continent has been growing increasingly important, this case study will not be examining American military expansion or U.S.China competition in the military sphere.

\section{$\underline{\text { Trade }}$}

According to Donald Rothchild (2002), while the U.S. is enthusiastic about trading with prosperous regions worldwide, it "hesitates to commit” to Africa. Looming threats on the continent, including civil war, authoritarianism, corruption, weak rule of law, and failure to embrace democracy, have resulted in a general avoidance (p. 239).

From 1974 - 1994, U.S. trade with Africa was governed by the Generalized System of Preferences (GSP), which gave duty-free access to exports (excluding key items like

\footnotetext{
${ }^{64}$ See Bush (9/19/06, 9/25/07) and Obama (9/23/09, 9/21/11).
} 
textiles) from developing countries. In effect, there was no official trade policy with Africa during this period (Rangel, 2003, p. 130). U.S.-Africa trade policy was concretized through the African Growth and Opportunity Act (AGOA) bill, ${ }^{65}$ passed in 2000, complemented by the USAID-run African Global Competitiveness Initiative. ${ }^{66}$ The bill called for an annual AGOA Forum meeting, to alternate between Washington, D.C. and African countries. AGOA is a nonreciprocal trade preference program (Williams, 2014, p. 1) that provides Sub-Saharan Africa with access to tariff-free trade, expertise and dialogue (International Trade Administration, 2014). Its purpose was to create economic growth and allow sub-Saharan Africa entrance into the global market. It has been renewed six times and its current authorization will expire in 2025 (Office of the U.S. Trade Representative, AGOA, 2014).

Eligibility criteria for AGOA which include showing progress on political pluralism and rule of law, addressing poverty, corruption, human rights and lowering of trade barriers, are reflective of the U.S. tendency to attach conditionalities to assistance. Forty-one sub-Saharan African countries are currently eligible for AGOA (Office of the U.S. Trade Representative, 2014). ${ }^{67}$ Concerns about AGOA have included the stringent qualifications needed to participate, an insistence on economic policy reform before the benefits of trade are realized, and a replacement of desperately needed aid (Morrison \&

\footnotetext{
${ }^{65}$ See also Natsios (9/14/05).

${ }^{66}$ This was designed to build trade capacity through African regional trade hubs (U.S. Department of State, 2005). See https://agoa2011.wordpress.com/usaid-regional-trade-hubs/ and http://20012009.state.gov/p/af/rls/fs/49817.htm for more information.
}

${ }^{67}$ Approval is subject to the President's judgment, and countries may be added or removed from AGOA eligibility through proclamations (Office of the U.S. Trade Representative, 2014). 
Cooke, 2001, p. 114). Relatively few African countries have taken advantage of AGOA, and there are concerns that there is little real transformation in the local economies in terms of global competitiveness (Williams, 2014, p. 13). AGOA, Hentz argued, is the embodiment of the Hamiltonian tradition, and was designed to "pick up where the IFIs [international financial institutions] failed" in incorporating Africa into the global market (Hentz, 2004, p. 34). Bacevich (2002) saw AGOA as "at best a promissory note, to be redeemed at Washington's convenience.” By no means had Africa attained higher international standing; in fact, he argued, Washington still had the "old map" of Africa firmly in mind, "depicting a slough of ethnic violence, extreme poverty, and daunting social problems, all presided over by brutal and venal kleptocrats” (p. 108-109).

The Office of the U.S. Trade Representative has stated that U.S. imports from subSaharan Africa under AGOA have risen threefold from 2001 to 2014, to \$26.8 billion. Nonpetroleum imports account for $\$ 4.9$ billion (Office of the U.S. Trade Representative, 2014). Oil is by far the top import from sub-Saharan Africa under AGOA, coming mainly from Nigeria, Angola, Chad, Gabon and Republic of Congo (Williams, 2014, p. 12). U.S. goods exports to sub-Saharan Africa in 2013 were $\$ 24$ billion, accounting for 1.5\% of total U.S. goods exports that year. U.S. goods imports from sub-Saharan Africa totaled $\$ 39.3$ billion in 2013, accounting for $1.7 \%$ of total goods imports (Office of the U.S. Trade Representative, Africa, 2014).

Hopes were high for those who worked on AGOA's passage. Senator Richard Lugar said: "Our bill signals the start of a new era in U.S.-African relations based less on bilateral aid ties and more on business relationships, less on paternalism and more on 
partnerships, and one that builds upon the long-term prospects of African societies rather than on short-term, reactive policies” (Rangel, 2003, p. 126).

AGOA has continuously been used by both the Bush $^{68}$ and Obama ${ }^{69}$ Administrations as proof of American commitment to the economic growth of Africa. However, AGOA can be seen as disappointing, as the bulk of U.S. imports from Africa are natural resources, ${ }^{70}$ and other trade has not grown significantly. While the balance of trade in Africa continues to favor the U.S., there is vulnerability to American domestic economic shocks and to possible future trade preferences with other world regions, supply-side issues in Africa have not been addressed, ${ }^{71}$ Africa remains unpopular as a location for FDI, ${ }^{72}$ and the relationship is unilateral (Chutha \& Kimenyi, 2011, p. 7). Further, undemocratic countries, or those with weak rule of law, are unpopular with businesses. ${ }^{73}$ Trade with Africa is small compared to that of the rest of the world, constituting about $2 \%$ of total U.S. trade.

In 2009 a candid conversation was held about the difficulties of investing in Africa between the U.S. Chamber of Commerce Africa Business Initiative and American executives. While there was recognition that Africa's market was growing, factors such as

\footnotetext{
${ }^{68}$ See Bush (5/16/01, 1/15/03) and Powell (5/25/01 (Witwatersrand), 11/7/02).

${ }^{69}$ See Obama (8/5/09), (8/23/10), U.S.-Africa Trade Relations, Liser (2009) and Akuetteh, Anderson \& Liser (7/31/13).

${ }^{70}$ See Clinton (6/14/10).

${ }^{71}$ See Clinton (6/14/10).

${ }^{72}$ See Rangel (2003), Chutha \& Kimenyi (2011) and Carson (6/13/12).

${ }^{73}$ See Carson (6/13/12).
} 
weak rule of law, a small middle class, the high risk to low reward ratio, lack of supportive business framework, an unwelcoming business environment, corruption, uncertainty, and opportunity cost made executives look to other, more attractive, global destinations.

African countries generally score poorly on Transparency International's Corruption Perceptions Index. ${ }^{74}$ The African Union found in 2002 that corruption cost Africa as a whole about $\$ 150$ billion a year. Corruption can be found in the form of large political scandals or as petty bribes for public services that should be free; both undermine trust in the government. Further, elected officials often view government funds as their own, leading to illegal activities to buy votes or otherwise remain in power (Hanson, 2009).

\section{President G.W. Bush and Africa}

During the year 2000 presidential debates between Al Gore and George W. Bush, Bush made it clear that, while Africa might be "important" it was certainly not one of his top foreign policy priorities (Bush, 10/11/00). "At some point in time," he said later, "the president has got to clearly define what the national strategic interests are, and while Africa may be important, it doesn't fit into the national strategic interests, as far as I can see them” (Bush, 2000, PBS News Hour).

Secretary Powell defended this statement, saying there were few military threats from the continent, and calling it "a huge continent in great need" with "pockets of success" (Powell, 2/4/01). Powell also defended Bush's commitment to Africa, calling him a believer in AGOA and its ability to "unleash the creative energies of the private sector."

\footnotetext{
${ }^{74}$ See http://www.transparency.org/research/cpi/overview.
} 
Further, he said that Bush believed that "by history and by choice, Africa matters deeply to America... [and] he may be leading a global war against terrorism, but he is here today to underscore just how high a priority Africa is...” (Powell, 10/20/01). Damage control continued throughout $2001 .^{75}$

However, despite outward signs of interest in Africa (which included AGOA (detailed in the section U.S. Interests in Africa), presidential trips in 2003 and 2008, ${ }^{76}$ pledges of interest and concern, ${ }^{77}$ and humanitarian aid $^{78}$ ), the Bush Administration reflected the American public's apparent belief ${ }^{79}$ that Africa was a quagmire of disease, conflict and corruption, ${ }^{80}$ low on the foreign policy priority list, ${ }^{81}$ but sometimes useful as a dodge. ${ }^{82}$ Bush stressed "moral responsibility" 83 to Africa, saying American activities there were a "calling” for a country with great wealth to share. ${ }^{84}$ The "new Africa” was

\footnotetext{
${ }^{75}$ See Powell (5/14/01, 5/22/01, 5/23/01, 5/25/01, 5/26/01, 5/27/01) and Fleischer (5/10/01).

${ }^{76}$ Much emphasis was put on Bush's decision to visit Africa in his first term (Rice, 7/3/03). Bush called his 2008 trip a "clear commitment signal" to Africa (Bush, 2/16/08).

${ }^{77}$ See Bush (6/26/03, 7/12/03, 6/10/05).

${ }^{78}$ In 2003, the President's Emergency Plan for AIDS Relief (PEPFAR) was founded with $\$ 15$ million guaranteed over 5 years. In 2005, the President's Malaria Initiative was founded with $\$ 1.2$ billion in funds. According to USAID, total foreign aid to Sub-Saharan Africa was $\$ 2.2$ billion in 2001, which steadily rose over the next several years, to $\$ 3.3$ billion in 2004, $\$ 4.9$ billion in 2005, $\$ 7.2$ billion in 2007 and $\$ 8.6$ billion in 2008 (The United States President’s Emergency Plan for AIDS Relief, 2105). See also Bush (9/23/03, 9/21/04, 9/14/05, 9/25/07, 9/23/08).

${ }^{79}$ See Hagos (2000), Mengara (2001), Keim (2014), and Mayer (2002).

${ }^{80}$ Corruption was seen in the context of crippling developing nations under globalization. See Powell $(6 / 27 / 03)$.

${ }^{81}$ See Powell (4/23/01, 5/14/01).

${ }^{82}$ See Powell (7/10/03) and Rice (12/21/06, 4/18/07).

${ }^{83}$ See Bush (6/26/03, 6/15/06, 2/17/08, 2/19/08).

${ }^{84}$ See Bush (7/3/03, 7/12/03, 6/30/05) and Rice (7/20/05).
} 
just on the horizon. ${ }^{85}$ However, the Administration was criticized for overlooking undemocratic actions of foreign leaders, and for focusing on terrorism at the expense of democracy. ${ }^{86}$

During this time, there seemed little question in leaders' minds that the U.S. was the natural, unchallenged partner for Africa. ${ }^{87}$ Secretary Powell exemplified this by saying, during his 2001 trip to Africa:

U.S. values are a good example of a model of what you achieve moving down a path of democracy... hopefully, [African leaders] will take the clue that if they continue to move in this direction, good things tend to happen to them. They get greater standing in the world community, more people are interested in providing them assistance... they are more likely to obtain trade opportunities... (Powell, 5/27/01).

However, the U.S. remained picky about the countries it would work with. ${ }^{88}$ On leaving office, ${ }^{89}$ President Bush said "People of Africa can be certain they will always have

\footnotetext{
${ }^{85}$ See Powell (6/27/03).

${ }^{86}$ See Democratic Developments (2007).

${ }^{87}$ See Rice (6/6/06, 7/15/08).

${ }^{88}$ See Powell (1/12/05), Bush (10/6/03, 6/10/05, 2/17/08) and Rice (7/20/05, 4/13/06, 1/23/08, 12/17/08, 7/23/07).

${ }^{89}$ In the 2001 report on the accomplishments of the G-7/8 Summit in Genoa, Italy, a list of Bush's activities in Africa boasted of a "new partnership", meetings with 7 African leaders, future development of an education initiative, the first meeting of the U.S.-Sub-Saharan African Trade and Economic Cooperation Forum, debt relief, the Global Fund for HIV, and a request that the World Bank increase assistance to the poorest countries (Office of the Press Secretary, 7/22/01). In a 2001 press release announcing strengthening of counter-terrorism and economic ties, the U.S. promised partnership to Africa, institution-building, trade expertise, help from the Overseas Private Investment Corporation (OPIC), the launch of the Trade for African Development and Enterprise Program, regional trade hubs, debt relief, increased World Bank grants, and other initiatives (Office of the Press Secretary, 10/29/01). See also Bush (2/14/08).
} 
a friend and partner in the U.S.” (Bush, 2/14/08). For the most part, the U.S. was seen positively by Africans at this time. ${ }^{90}$

\section{President Obama and Africa- Up to 2010}

This section will summarize the Obama Administration's outlook on Africa from 2009 - 2010. Activities from 2011 - 2014 will be discussed in later chapters. Early praise was given to President Bush by the Administration for his work in Africa, ${ }^{91}$ along with promises to continue programs like PEPFAR. ${ }^{92}$ There was a sense that Africa had been moved from "the margins to the mainstream (if not center) of U.S. foreign policy" (Carson, 6/25/09). ${ }^{93}$ Early expectations for Obama's foreign policy in Africa rested on his Kenyan heritage $^{94}$ and his 2009 stopover in Ghana, ${ }^{95}$ meant to showcase Africa as part of the international system. ${ }^{96}$ Secretary Clinton visited Africa at the beginning of her tenure, ${ }^{97}$ reflecting the idea that an early visit signified foreign policy importance. President Obama invited 25 African heads of state and the African Union Commissioner to a luncheon in

\footnotetext{
${ }^{90}$ See Rice (12/18/08) and African Opinion (2007).

${ }^{91}$ See Garland (1/29/09) and Carter III (2/9/09).

${ }^{92}$ See Obama (9/21/11) and Sammis (10/3/11).

${ }^{93}$ See also Carson (7/30/09, 6/14/10).

${ }^{94}$ See Garland (1/29/09), Carson (6/25/09) and Obama (9/23/09).

${ }^{95}$ See Obama (7/11/09) and Gavin (7/9/09).

${ }^{96}$ See Obama (7/11/09) where he stated: "I do not see the countries and peoples of Africa as a world apart; I see Africa as a fundamental part of our interconnected world..."

${ }^{97}$ See Carson (7/30/09) and Clinton (8/6/09, Interview with Bill Odidi).
} 
Washington, D.C. in September, 2009. It was called "the start of a dialogue” meant to “move this partnership forward and achieve some real transformation” (Gavin, 9/22/09).

Early on, the Administration’s theme was essentially that “Africans are responsible for Africa,”98 eschewing “excuses about corruption, poor governance... neo-colonialism or the West being oppressive or racist” (Obama, 7/7/09). Further, the U.S. continued pressing for good governance. ${ }^{99}$ However, Secretary Clinton began to show recognition ${ }^{100}$ of the opportunities Africa seemed to hold, if only the U.S. wished to "seize them"; if it did, she said, the U.S. would be Africa’s “partner... not patron” (Clinton, 8/5/09). There was a sense in 2009 of "starting over" and re-defining U.S. goals for Africa, amidst a perception that Africa presented both opportunity and danger (New Beginnings, Clinton, 2009). In 2010, the administration began talking about Africa in terms of what it could do for the U.S., especially in terms of stopping disease from spreading, buying American products, and creating jobs for American workers. ${ }^{101}$ Leaders continued to believe popularity was high, ${ }^{102}$ which was seen as signifying African support for American policies, right up to a 2012 Gallup poll showed “major declines” in African support for the U.S., dropping in some countries 25 percentage points. China, meanwhile, gained upwards of 30 percentage points in some areas (Center for Public Diplomacy Blog, 2012).

\footnotetext{
${ }^{98}$ See Obama (8/23/10), Clinton (6/14/10) and Voice of America (6/9/11).

${ }^{99}$ See Obama (7/7/09), Carter (2009) and Clinton (10/1/09).

${ }^{100}$ See Clinton (10/1/09).

101 See Obama (8/23/10).

102 See Obama (8/23/10) and FY2012 Budget Request, Carson (4/4/11).
} 
However, these early indicators of support for Africa appeared to be continuations of the previous Administration's work in Africa, and did not appear to signify a serious desire to ramp up Africa policy or to elevate it in American foreign policy. Attention to Africa proceeded in fits and stops, and would not be serious until around 2011, as shown later in this case study.

Interviewees had extensive experience working in and with Africa. Respondent A helped plan U.S. policy in Sudan, Darfur and West Africa. Respondent B was an Ambassador and decision maker in Washington, DC. Respondent C's firm worked with institutions in Africa on reform, including infrastructure policy, corruption and banking; this respondent also formerly worked with the IMF. Respondent D served as Ambassador in several African posts and in a UN Mission. Respondents saw mixed success with policies they had been involved in. Respondent A focused particularly on security issues (i.e., Sudan, Cote d'Ivoire and Mali). Respondent D had seen "notable successes in conflict resolution and economic development (e.g. passage and implementation of AGOA) and more limited success in general development and anti-terrorism issues.” The difficulty noted by this respondent related to issues of state-building, and the "limited media and public attention and constituencies for African-related issues.”

Respondents generally found that Africa's importance to the U.S. has been low, with some slow increases over time. "[There is] growing importance, but [it's] still low compared with other world regions,” said Respondent A. Respondent C noted that interest in Africa has fluctuated among different presidential administrations, but said that "in the last few years, Africa has not been very high in U.S. foreign policy's agenda.” Respondent D said that, although oil, terrorism and trade had "sparked some increasing interest" the 
U.S. "has not seen itself having major strategic interests" there and Africa has thus been "a lower priority” than other parts of the world. Respondents noted the following priorities for the U.S. in Africa: conflict mitigation, democracy promotion, economic growth, development, counter-terrorism, human rights, investment promotion, peace, security, development, and health. Respondent C noted a shift in priorities from health and governance in the early 2000s to energy. Respondent D saw an increase in trade and economic activity, particularly related to oil, and an increased focus on terrorism, particularly in West Africa, the Horn of Africa and Sudan. Some respondents had seen a change in priorities over time, especially in terrorism and energy production. Respondent D said these changes "have sparked some increased interest, albeit limited, in issues of general stability and economic opportunity and development.” Respondent B had not seen change over time. Respondent A had seen a "change in emphasis, not wholesale policy. Our core interests in Africa remain largely unchanged.” Respondent B said policies had "evolved." Respondent D said, "I believe the general direction and objectives of U.S. policies in Africa have generally been maintained, and are by and large not driven by U.S. partisan politics.” However, some priorities have changed due to country developments and administration changes. Two respondents felt that policies have evolved over time. Interviewees were mixed on their feelings about whether the U.S. cared about its image in Africa. Respondent B felt the U.S. was concerned, while Respondent A said the U.S. was "not majorly concerned." Respondent C said "The U.S. has not made any campaign or sent strong messages showing concern about its image in Africa.” Respondent D said they did not believe the image to be "a major priority for Washington.” This has at times been an issue, as with the launch of AFRICOM. However, this respondent noted that 
the U.S. enjoys a good image in Africa, despite some lingering suspicion of U.S. activities in some quarters, such as South Africa. This lack of concern for image in Africa reflects a tendency for the U.S. to neglect Africa, and to assume African goodwill. However, as will be seen in future chapters, this lack of concern for image will change.

All the interviewees believed that U.S. actions toward Africa were solely based on domestic interests. Respondent A thought that U.S. engagement in Africa is “driven by our own interests, and not competition with China.” Respondent C thought that the U.S. has not had any greater interest in doing business with Africa or having a stronger presence in the past few years.” Respondent D said, "I believe there has been growing commercial and general economic interest in Africa by the U.S. and generally American companies. While both official and private U.S. officials are certainly aware of growing Chinese activities, I think the U.S. interest is driven by economic and commercial opportunities, not the Chinese activities as such.” This belief may not reflect what is actually happening in the U.S. response.

The American Understanding of Chinese Activities in Africa Before 2005

In the Bush Administration, there was little mention of Chinese activities in Africa, and both the President and Congress seemed largely unaware of any encroachment by China. One exception was the testimony of J. Robinson West, Chairman of the Petroleum Finance Company, in his 2000 testimony before the House Subcommittee on Africa on “Africa’s Energy Potential.” When asked about China's activities in the oil sector in Africa, West replied "I do not think they are involved in any significant activities in Africa at this point... I think the Chinese are going to be watching Africa, but they are watching 
the whole world and this is one of the areas where their economy is going to move.” In 2003, Secretary Powell, in an interview by the New York Times, mentioned China and Africa in the same breath, but for different reasons. "[We will work on] continuing to build the relationship with Russia and China... expanding AGOA, working with African nations not only on HIV/AIDS and infectious diseases, but economic development, the Millennium Challenge Account...” (3/29/03). These were the only major mentions of China and Africa found during this time period.

\section{American Awareness of Chinese Diplomatic Summits in Africa}

American awareness of the Forum on China-Africa Cooperation (FOCAC) summit meetings, first held in the year 2000, appeared to be delayed. The first mention of FOCAC by Congress was in 2005 at a House Subcommittee on Africa, Global Human Rights and International Operations hearing on AGOA. Congressman Gregory Meeks noted a number of projects China had invested in on the continent, ${ }^{103}$ along with China's specific Africa policies, which included: (1) the five principles of co-existence and non-interference, (2) to support regional organizational efforts at stability, (3) increased exchanges of visits at all levels, (4) to work through FOCAC, and (5) to stand up for Africa in the international community (African Growth and Opportunity Act, p. 10-11).

In another 2005 hearing before the House Subcommittee on Africa, Global Human Rights and International Operations on China's influence in Africa, FOCAC’s existence was acknowledged and some of its activities, including cancellation of debt, Chinese

\footnotetext{
${ }^{103}$ These included oil production technology in Nigeria, roads in Rwanda and Kenya, mines in Zambia, joint ventures and increased trade.
} 
scholarships for African students and support for an African Union seat in the UN Security Council, were mentioned (China’s Influence in Africa, p. 9 - 14). Here, Deputy Assistant Secretary Michael Ranneberger called the 2000 FOCAC summit “a vehicle for expanding Sino-African economic, trade, and political ties" and showed awareness of the 2003 summit in Addis Ababa. Ranneberger's understanding of motivations for Chinese activities in Africa centered on new markets, access to raw materials, support on Taiwan, and demonstration of China's rise as an important world power (p. 20). Ranneberger noted that both summits "had high-level representation, including African presidents, vice presidents, prime ministers, and foreign ministers. China’s President, Vice President, and Premier were all present at the first FOCAC Conference, in Beijing. Premier Wen Jiabao represented China at the second FOCAC Conference, held in Addis Ababa in December 2003.” He made it clear that China’s increased African diplomacy was well-known, visible in meetings and exchanges of high ranking officials, with "numerous" visits of Africans to China. "This commitment to Sino-African diplomacy is not new," he said. "For the past seventeen years the Chinese foreign minister has begun each new year with a trip to Africa. China's official presence in a number of African countries also is being upgraded significantly..." (China's Influence in Africa, p. 20). Yet he cautioned that "we should not overestimate Africa's place in China’s foreign policy or its influence in Africa” (p. 21). Dr. Ernest Wilson of the University of Maryland then noted that China drew on its traditional positioning as leader of the Third World when creating FOCAC. Wilson called FOCAC "an umbrella organization designed to encourage better diplomatic relations, trade and investment” (China’s Influence in Africa, p. 57). 
Beyond this brief flurry of recognition in 2005, no evidence was found that FOCAC was mentioned again publicly, by name, by any government officials or members of Congress through the year 2014. However, a 2006 cable released by Wikileaks provided a detailed summary by U.S. diplomats in China of preparations for the FOCAC meeting taking place that year in Beijing. The cable discussed the expected "Beijing Action Plan," which would help China "institutionalize the FOCAC mechanism as China's primary vehicle for engaging Africa." China was expected to "seek financial services penetration on the continent, offer an oblique commitment to African involvement in UN Security Council reform, highlight China's desire to be involved in shaping African counterterrorism initiatives and signal China's commitment to proactive public diplomacy in support of China's agenda in Africa.”

These diplomats expected the summit to "generate significant publicity for SinoAfrican ties and herald for the international community China's role as a major player in Africa." The cable reported that at least 40 heads of state from Africa were expected to attend, including the five countries "still in the Taiwan camp" as observers. Outside involvement in the summit was shown to be limited to U.N. agencies and African regional organizations (the European Union was excluded after requesting observer status). The cable summarized the draft "Beijing Declaration," calling it a "political statement containing platitudes about friendship and cooperation and the establishment of a 'new type of strategic partnership"” (Wikileaks, PRC/Africa, 2006).

The authors of the cable rejected the idea that the summit was strictly meant for public relations purposes, stating: 
China's business interests are overt... Africa has benefited from SinoAfrican trade despite trade imbalances, China does not carry any colonialera 'baggage,' and provided important support for many African liberation struggles, and China genuinely treats African leaders, governments and businesses with respect.

Interviewees were aware of some FOCAC meetings, as shown in Figure 3 below.

Figure 3: FOCAC Awareness Among Interview Respondents

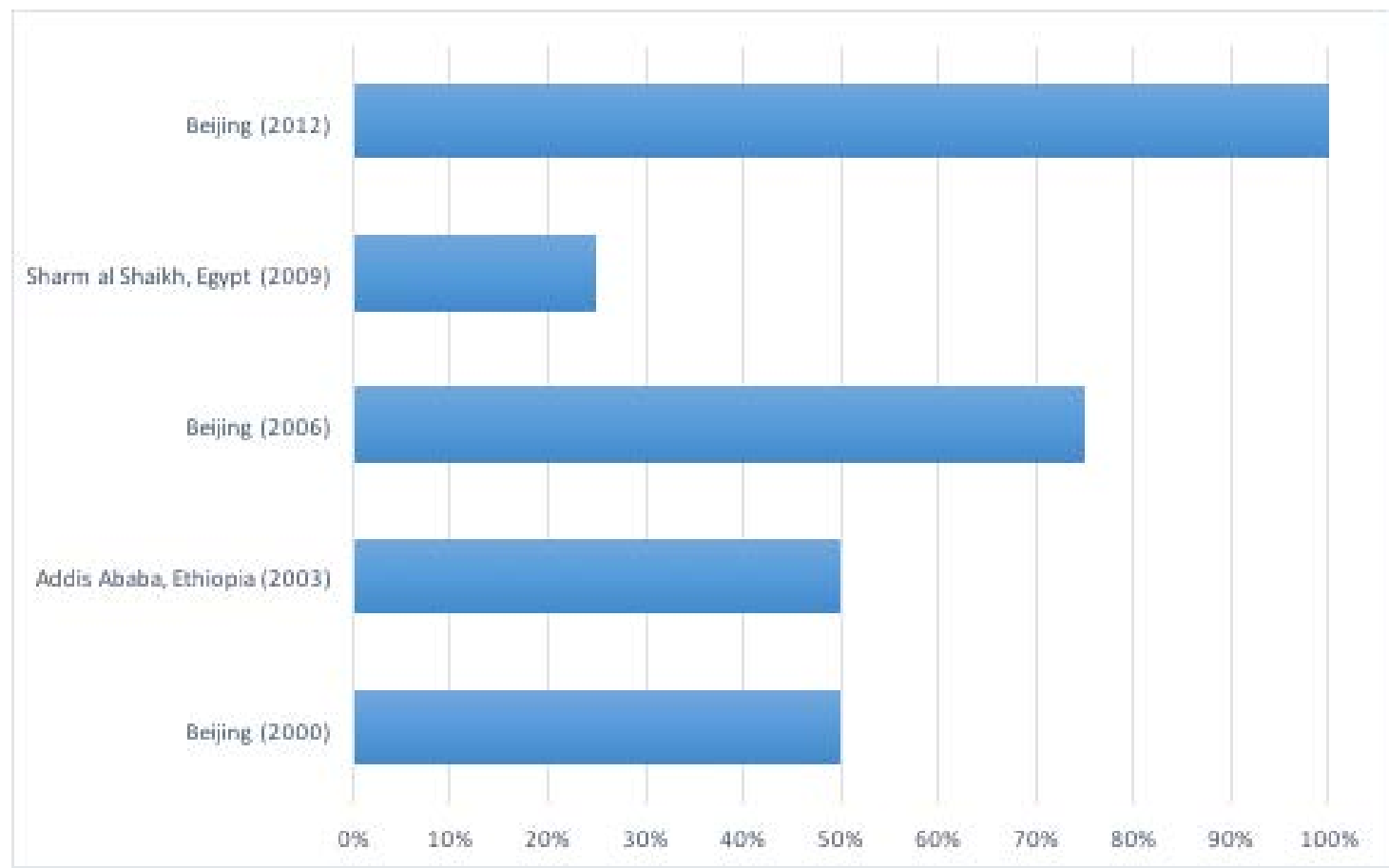

Interviewees were aware of the benefits China received from FOCAC meetings. Respondent A felt that they were "a means by which China try to buy influence." Respondent C saw FOCAC as a way for China to position itself in Africa. Respondent D said "I believe these [meetings] generally generated favorable domestic media attention for African states, and undoubtedly helped reinforce relations with key African leaders as well 
as commercial relationships. As such, I thought they were certainly viewed as successful in Beijing and at least many African capitals. I am not convinced, however, that they necessarily represented major strategic shifts in relations or alignments.”

Respondent D also noted that reactions to FOCAC among American and European colleagues ranged from “alarm” to simply being the result "of generally growing Chinese global activity, certainly in Africa, predictable if not inevitable as China emerged as a growing world power and as such posing opportunities for cooperation as well as political and commercial competition.”

Respondent D was also aware of some of the agreements and activities arising from FOCAC, seeing them as "evidence of growing Chinese activity reflecting both growing commercial and general economic interests, and increasing Chinese interest to play a role as a true world power. In short, activities generally consistent with a continuing shift and global relationships reflecting growing Chinese in importance and a general role in the region and the world in generally.”

\section{Sounding The Alarm}

Much of the discourse on China in Africa in Congress between 2005 and 2013 centered on the void in Africa created by American neglect and past mistakes, ${ }^{104}$ and China's willingness to fill that void. ${ }^{105}$ Not only was China seen as ubiquitous on the

\footnotetext{
${ }^{104}$ See The African Growth and Opportunity Act: A Five-Year Assessment (2005, Payne, p. 7 and Meeks, p. 10-11), China's Influence in Africa (2005, Payne, p. 9-10 and Lee, p. 13-14), and Resource Curse or Blessing? (2008, Goldwyn, p. 37), and Voice of America (6/25/13).

${ }^{105}$ See China's Influence in Africa (2005, Payne, p. 9-10 and Wilson, p. 55), Energy Trends in China and India (2005, Wayne), The Millennium Challenge Corporation in Africa (2007, Carroll), Efforts to Deal with America's Image (2007, Curtis), Congressional Research Service (2008, p. 12), Energy Security (2009, J.
} 
continent, ${ }^{106}$ it was deepening ties, ${ }^{107}$ sometimes through secretive, ${ }^{108}$ nefarious methods antithetical to American desires, ${ }^{109}$ and creating an opportunity for African leaders to play the U.S. against China. ${ }^{110}$ Although not seen as threatening the activities were still a concern, ${ }^{111}$ labeled by at least one Congressman as an "abandoning of [China's] peaceful rise policy” (Emerging Threat of Resource Wars, 2013, p. 2). An interested U.S. could win Africans back in a moment, if only it would change its operations there, because Africans had a natural love for America. ${ }^{112}$ In other words, their dealings with China (and other

Carter, p. 17), Assessing U.S. Foreign Policy Priorities and Assessing China's Behavior (2011, Berman), Economic Statecraft: Increasing American Jobs (2012, Durbin), Smith (2012, p. 1), Emerging Threat of Resource Wars (2013, Rohrabacher, p. 2 and Adams, p. 75), and Is There an African Resource Curse? (2013, Smith, p. 53).

${ }^{106}$ See Feingold \& Thiam (2005) and Assessing the Fiscal Year 2012 Budget for Africa (2011, Fine, p. 4344).

${ }^{107}$ See Efforts to Deal with America's Image Abroad (2007, Delahunt), China’s Role in Africa (2011, Shinn, p. 8-11 and Hayes, p. 26), Assessing China's Role and Influence (2012, Hayes, p. 87), The African Growth and Opportunity Act: Ensuring Success (2012, Hayes, p. 35). Interestingly, Pres. Obama traveled to Africa as a Senator in 2006, and was alarmed by Chinese activities there, saying that "the United States' absence is as noticeable and prominent as the Chinese's presence.” In 2008, he wrote that China's influence in Africa was "among the most significant developments on the continent since the end of the Cold War. In his 2008 presidential campaign, he urged the U.S. to upgrade its African activities to match China's (Morrison \& Cooke, 2009, p. 152-153). It is unknown why Obama would act in this way, yet neglect Africa and refuse to acknowledge Chinese activities as problematic once elected president.

${ }^{108}$ See Examining Prospects for Democratic Reform (2013, Gast, p. 15).

${ }^{109}$ See China's Influence in Africa (2005, Smith, p. 3-4, Wilson, p. 55, and Bartholomew, p. 48-50), Nigeria's Struggle with Corruption (2006, Goldwyn, p. 65-66), Beyond Oil and Gas (2007, Royce, p. 22), Foreign Policy and National Security Implications of Oil Dependence (2007, Royce, p. 9-10), Democratic Developments (2007, Rotberg, p. 69), African Opinion (2007, Tancredo), Rising Oil Prices (2008, Berman, p. 1), Foreign Aid and the Fight Against Terrorism (2008, Royce, p. 5 and Farah, p. 110), Resource Curse or Blessing? (2008, Goldwyn, p. 37-38), Changing Energy Markets (2011, Royce, p. 1), China's Role in Africa (2011, Coons, p. 2-3 and Shinn, p. 7), Assessing the Fiscal Year 2012 Budget for Africa (2011, Fine, p. 4344), Economic Statecraft: Increasing American Jobs (2012, Hochberg, p. 8-9 and Durbin, p. 24-25).

${ }^{110}$ See Nigeria’s Struggle with Corruption (2006, Ayittey, p. 66) and China’s Role in Africa (2011, Shinn, p. 10).

${ }^{111}$ See China’s Influence in Africa (2005, Wilson, p. 55) and China’s Role in Africa (2011, Shinn, p. 11).

112 See China's Influence in Africa (2005, Payne, p. 11-12), Beyond Oil and Gas (2007, Fortenberry, p. 20), China in Africa (2008, Economy, p. 26-27), China’s Role in Africa (2011, Isakson, p. 4), Assessing China’s 
states ${ }^{113}$ ) were instrumental, ${ }^{114}$ and only because America had become too difficult a partner; regardless, Africa was being lost. ${ }^{115}$ Further, the U.S. could use this opportunity to better understand its own relationship with China. ${ }^{116}$ Recommendations for the U.S. ranged from engaging with the Chinese, warning the Chinese of the downsides of working with corrupt dictators, engaging with Africans on the issue, and assisting Africans on improving their textile industry (China’s Influence in Africa, 2005, p. 59). ${ }^{117}$

In 2010, Wikileaks published a group of diplomatic cables which revealed how officials on the ground viewed African leaders, and China's activities in Africa. Some of the cables featured African leaders lamenting that China’s "aggression” and "coercion” have caused it to "lose friends." Others were more positive about China's involvement. In a cable dated February 11, 2010, a U.S. diplomat reported that Julius Ole Sunkuli, Kenya’s ambassador to China, said that “Africa was better off thanks to China's practical, bilateral approach to development assistance and that this would be changed by western interference.”

Role and Influence in Africa (2012, Fortenberry, p. 4-6 and Lee, p. 6), Economic Statecraft: Embracing Africa's Market Potential (2012, Sanchez, p. 26), and Examining Prospects for Democratic Reform (2013, Gast, p. 15).

${ }^{113}$ See China's Influence in Africa (2005, Wilson, p. 59), U.S.-Africa Trade Relations (2009, Cook, p. 60), Assessing China's Behavior (2012, Pham, p. 52).

${ }^{114}$ See China in Africa (2008, Economy, p. 25).

${ }^{115}$ See Economic Statecraft: Increasing American Jobs (2012, Coons, p. 2).

${ }^{116}$ See China’s Influence in Africa (2005, Payne, p. 11-12), The Millennium Challenge Corporation in Africa (2007, Carroll), China in Africa (2008, Economy, p. 25 and 42), China’s Role in Africa (2011, Shinn, p. 1112).

${ }^{117}$ See also China’s Role in Africa (2011, Hayes, p. 27-28) and China in Africa (2008, Feingold, p. 2). 
The overall effect of the cables on U.S.-Africa relations "forces Africans to question the U.S.'s role [in Africa] and to voice serious doubts about the U.S.” The leaks also led Africans to question “America's image as the superpower of the world. It further destroys the aura of invincibility that the U.S. once had - especially in Africa - and that we’ve seen eroded since the 9/11 attacks and invasion of Iraq.”

In a cable dated February 5, 2009, two African diplomats (Emile Rwagasana of Rwanda and Tony Alonwu of Nigeria) called China’s activity in Africa a "mixed blessing” in contrast to "China's rosy official view of relations with Africa," noting the power imbalance between behemoth China and small, poor African countries. Rwagasana believed that China's Africa relations were fueled by demand for resources, which led China to want to "conquer the continent," preying on African "weakness" to "set the terms of cooperation." "How can we win [referring to the Chinese foreign policy of win-win cooperation] when the buyer sets the price?” Rwagasana asked. “There's a feeling among Africans that if China will not invest, no one will, and African resources will be wasted," he continued. Alonwu acknowledged that Nigeria had fairer relations with China, being larger, but that he felt smaller African countries were being “coerced” into accepting unfair deals.

This cable described China's building of the Rwandan Ministry of Foreign Affairs headquarters, and China's attempts to smooth over rough patches in Nigeria. ${ }^{118}$ Rwagasana believed that China was effectively utilizing soft power in Rwanda, through Confucius Institutes, Chinese language classes, and the building of a malaria prevention and treatment

\footnotetext{
${ }^{118}$ Such as the cancellation of a railway contract and the failure of a Chinese-made communications satellite.
} 
center. The cable summed up the diplomats' experiences by saying "While we are not prepared to say that such negative sentiments about China's relations with Africa apply across the board to African diplomats in Beijing, we do note the disparity between the friendly official ties and the private expressions of resentment.” The same cable showed an understanding of specific Chinese activities in Africa, including Foreign Minister Yang Jiechi's recently concluded trip to Rwanda, Uganda, South Africa and Malawi, and President Hu Jintao's upcoming trip to Mali, Senegal, Tanzania and Mauritius, along with surrounding Xinhua news items on the trips. The cable summarized a meeting between $\mathrm{He}$ Wenping of the Chinese Academy of Social Sciences (CASS) and an embassy officer, where He said that "equality and mutual benefit were the most important principles of Chinese aid to Africa."

In a cable dated February 11, 2010, U.S. diplomats, including Ambassador Jon Huntsman, were told by African Embassy officials in China that "many in the African community were uncomfortable with the concept of U.S.-China development cooperation in Africa,” especially in light of China’s “fast, efficient, 'no strings attached' approach” and its focus on infrastructure. U.S.-China or E.U.-China cooperation on Africa was seen as "interference," as demonstrated by the incident where an E.U.-China-Africa trilateral cooperation meeting was canceled by the Chinese due to African concerns. ${ }^{119}$ This theme was reiterated when the same cable summarized a meeting with Kenyan Ambassador to

\footnotetext{
119 South African Minister Dave Malcolmson was quoted as saying that "many African countries were annoyed because they were not consulted" on this trilateral attempt. "[African countries] perceived this as a Western attempt to rein in China's Africa assistance.” In fact, the African officials said that "competition between donors has had positive consequences for African development, giving the African countries options after several decades of a largely 'Western' development model.” The "principal fear" for African countries was seen as an attempt by the West to use trilateral cooperation as a way of "attaching governance conditions to Chinese development.”
} 
China Julius Ole Sunkuli. Sunkuli said that "Africa had nothing to gain from China cooperating with the international donor community" and that Africans were "frustrated by Western insistence on capacity building which [he saw as] conferences and seminars.” Infrastructure and leverage were key positive sides to Chinese aid.

Malcolmson noted that there was a change in perception of Africa by traditional Western donors after the 2006 FOCAC summit. This signaled a recognition that "they had to measure up to China” and came calling. Any cooperation should go through regional African organizations, Malcolmson advised, and could have the benefit of "encouraging the Chinese to venture beyond bilateral development assistance and support regional projects." The diplomats summed up their understanding of the situation in the cable in this way:

Sunkuli and Malcolmson's comments are a potential warning sign as the U.S. Government prepares for the upcoming U.S.-China Sub-Dialogue on Africa... China could well use any voiced African opposition as an excuse to stop or slow progress on further discussions or collaboration. We should be careful to pick projects that would have broad support within the African community, preferably African-initiated and led, to get the development cooperation dialogue started on the right foot. In addition, we should clearly articulate the benefits of our cooperation to our African counterparts and include African voices in the debate on the U.S.-China-Africa relationship.

In a cable dated February 23, 2010, summarizing Assistant Secretary Carson’s 
meeting with members of International Oil Companies (IOCs), Nigeria was identified as “the most important country in Africa for the United States.” When asked about American influence in Africa compared to China's, Carson said the U.S. had a "stable reputation" and the highest popularity of any global region. ${ }^{120}$ While not considering China "a military, security or intelligence threat," Carson said it was a "very aggressive and pernicious economic competitor with no morals.” Carson listed his understanding of why China was in Africa for “non-altruistic reasons”: (1) China’s economic gain, (2) to secure U.N. votes from African countries, and (3) to gain African support on Taiwan. Concerning China as a direct threat, Carson named several "tripwires" for the U.S. that would result in greater concern. These included development of a blue water navy, military base agreements, increased army training, and intelligence operations. Carson assured the group that the U.S. “will continue to push democracy and capitalism” even while “Chinese authoritarian capitalism is politically challenging," engaging as it does the "Mugabes and Bashirs of the world.”

It appears, then, that certain Congresspeople were well aware of American neglect of Africa, and concerned that China was filling the gap. Their recognition centered on power loss on the continent, as China conducted its activities in a way that was not only antithetical to what the U.S. wanted but undermined its position of authority.

At that point, they appeared to believe it was possible to win Africa back by becoming a better partner, and also recommended communicating with the Chinese

\footnotetext{
${ }^{120}$ See also Obama (8/23/10) where he stated that "Africa has some of our most loyal friends... it turns out Africa generally has a positive view of America...”
} 
directly to change their ways in Africa. As will be seen in later chapters, officials eventually did exactly that.

Diplomats were engaged in warning officials back in Washington, D.C. of the onthe-ground reality of Chinese activities. Again, the key message was that the U.S. was losing its stature, and losing Africa. The cables also give a better sense of how officials might have been trying to manage the situation in person. Assistant Secretary Carson's message that China was "aggressive and pernicious" and that the U.S. would continue to "push democracy and capitalism” was at once tough on China and also designed to show that the U.S. would not back down from its traditional platform to address this competitor. This reluctance on the part of the State Department to accept the loss of power Congresspeople and diplomats warned about will be demonstrated further in the next section.

\section{American Leaders' Early Reaction to Chinese Activities in Africa}

Leaders in the State Department and White House appeared to have a stock supply of answers to the concerns shown by Congress and diplomats on the ground (although they also sometimes ignored or evaded the issue entirely). ${ }^{121}$ The first set of answers centered on defending American activities in Africa, fighting off claims of neglect, and insisting there were close, even unshakeable, U.S.-Africa ties. ${ }^{122}$ An example of this can be seen in Deputy Assistant Secretary for African Affairs Michael Ranneberger’s statement before

\footnotetext{
${ }^{121}$ See Gibbs (4/26/10), Donilon (1/14/11) and Earnest (3/28/13).

${ }^{122}$ See China's Influence in Africa (2005, Ranneberger, p. 18 and 21-24 and 29), Perino (2/19/08), Bush (2/20/08), Rice (9/5/08), China in Africa (2008, Swan \& Christensen, p. 8-12).
} 
the House Subcommittee on Africa, Global Human Rights and International operations in 2005 on China's influence in Africa. "The United States is engaged with Africa as never before," he asserted. "Much of Africa is undergoing a positive long-term transformation that we are supporting” (p. 18 \& 23). The second set focused on China's activities in Africa as the natural result of growth, ${ }^{123}$ definitely not a zero-sum type of competition, ${ }^{124}$ and perhaps even helpful ${ }^{125}$ or at least benign. ${ }^{126}$ An example of this can be seen in the joint testimony of James Swan and Thomas Christensen in 2008 before the Senate Subcommittee on African Affairs on China in Africa. They said that "China's growing activity on the continent [was] a potentially positive force for economic development there.” They did not see zero-sum competition, nor did they believe China was deliberately trying to reduce American influence in Africa. The third set centered on avoiding competition with China, ${ }^{127}$ and shaping its activities, ${ }^{128}$ mainly through increased engagement. ${ }^{129}$ An example of this comes from the same 2008 Swan and Christensen

\footnotetext{
${ }^{123}$ See China's Influence in Africa (2005, Ranneberger, p. 37), Rice (4/19/06), Swan (2007), China in Africa (2008, Swan \& Christensen, p. 8-12 and 19-20), Assessing China’s Behavior (2011, Sutter, p. 41, and Carson (2011, p. 54).

${ }^{124}$ See Bush (2/20/08), Rice (9/5/08), China in Africa (2008, Swan \& Christensen, p. 8), Morrison (2008, p. 34-45), Carson (2011, p. 54), and Morrison \& Cooke (2009, p. 149-151).

${ }^{125}$ See China's Influence in Africa (2005, Ranneberger, p. 18-19 and 23-24), Beyond Oil and Gas (2007, Liser, p. 19-20), Resource Curse or Blessing? (2008, Gallogly, p. 15), China in Africa (2008, Swan \& Christensen, p. 8), U.S.-Africa Trade Relations (2009, Liser, p. 37), Marantis (6/13/12), and Kerry (12/16/14).

${ }^{126}$ See An Overview of U.S. Policy (2010, Carson, p. 40).

${ }^{127}$ See China’s Influence in Africa (2005, Ranneberger, p. 23 and 29), and Rice (9/5/08).

${ }^{128}$ See China in Africa (2008, Swan \& Christensen, p. 22-23), U.S.-Africa Trade Relations (2009, Liser, p. 37), and Carter (2009, p. 25-26).

${ }^{129}$ See China's Influence in Africa (2005, Ranneberger, p. 29), China in Africa (2008, Swan \& Christensen, p. 8), Morrison (2008, p. 34-35), FY2012 Budget Request (2011, Carson, p. 54), Obama (1/19/11), Assessing China's Role (2012, Yamamoto, p. 7 and 22-25), and Examining Prospects for Democratic Reform (2013, Yamamoto, p. 15).
} 
testimony. "Our goal, as with other areas of the world," they testified, "is to engage Chinese officials to try to define and expand a common agenda for Africa that ultimately will serve both our national interests and maximize the benefit Africa derives...” The fourth set was a conscious claim to "welcome" other countries into Africa. ${ }^{130}$ The fifth was the claim that the U.S. presence and agenda in Africa was unrelated to China’s. ${ }^{131}$

Some interviewees believed that the U.S. and China were not in competition in Africa. Respondent B said “African countries and populations have not always reacted positively to Chinese activities in Africa.” Respondent C said, “the U.S. and China are not active in the same sectors in Africa. Therefore, there is no stiff competition yet.”

Respondent D said, "I believe this fear exists among some, but not necessarily those most knowledgeable or informed of conditions in Africa. I suspect this fear emerges mostly from the global reality of China emerging as a major global economic power, with at least some indications of a growing desire and capability of playing a major political or military global role as well.”

There are several possible reasons why leaders - and interviewees - chose to downplay the significance of Chinese activities in Africa in this period of time. Perhaps they did not fully understand the on-the-ground reality, or were simply following the American public's general neglect of Africa. It is also possible that leaders believed that they might calm the fears of those who were more concerned by denying there was any

\footnotetext{
130 See Perino (2/19/08). Officials in the later period also used this same term. See Obama (6/27/13 and 6/29/13), Liser (7/31/13).

${ }^{131}$ See Carson (7/30/09). See also comments in the later period by Senior Official (8/4/12), Obama (6/29/13), Akuetteh, Anderson and Liser (7/31/13).
} 
kind of issue. Leaders may also have felt that those who were concerned in Congress were motivated by reactionary anti-China politics, or that devoting too much time or attention to the issue might draw criticism from an American public more concerned about other foreign policy issues or regions.

However, the explanation which seems to make the most sense in this situation, based on discourse, is that the U.S. appeared to equate China with every other purely economic actor working in Africa, with perhaps a few slightly disturbing operational methods. The U.S., so aware of competition with China in its direct relationship, may have been blind to the status competition that was occurring in Africa between the two.

Leaders may not have been downplaying the significance of Chinese activities in Africa because they believed they were dangerous or embarrassing but because they did not recognize them for what they truly represented to the U.S. Over time, as will be shown in the next several chapters, leaders seem to have gradually come to perceive these activities as not only problematic but as representative of status competition.

\section{$\underline{\text { Conclusion }}$}

This chapter explored the neglect the U.S. has shown to Africa, as well as the divergent reactions of members of Congress, diplomats, State Department and White House staff to Chinese activities in Africa. The former two groups found the activities disturbing and evidence that the U.S. was "losing” Africa, while the latter two defended American activities in Africa and refused to see Chinese activities as problematic or in any way different from what other countries may have been doing in Africa. 
The next chapter will explore the quiet countermeasures the U.S. began to take as related to a growing, but unstated, change in perception about Chinese activities in Africa. The U.S. appears to have begun to see economic loss, as well as power loss, especially in its ability to shape African leaders’ actions.

At that point, relative gains concerns began to affect U.S. actions, which it appears to have attempted to ameliorate through diplomatic engagement. Perception of status competition was nascent, but the U.S. did keep its engagement quiet, perhaps in order to stem any discourse that China was in fact gaining in this area. 


\section{CHAPTER SIX: GROWING AMERICAN CONCERN}

\section{$\underline{\text { Introduction }}$}

In the previous chapter, American neglect of Africa was examined, along with the early reaction of American leaders and other officials, like members of Congress, to Chinese activities in Africa was explained using discourse and official documents. This reaction was split, with State Department and White House leaders downplaying the importance of Chinese activities in Africa, while members of Congress and some on-theground diplomats showed alarm and concern.

This chapter will explore the third observed outcome of this case study, which is that American officials (especially from the White House and State Department) ultimately became concerned about Chinese activities in Africa, and began to take subtle countermeasures. Discourse did not change during this period (2005 - 2011), but it can be inferred that the quiet countermeasures the U.S. began to take may have been related to a growing, but unstated, change in perception about Chinese activities in Africa. The U.S. appears to have begun to notice both economic and power loss, especially in the ability to shape African leaders' actions. At that point, relative gains concerns began to affect American actions, which it may have attempted to ameliorate through diplomatic engagement. Perception of status competition seems to have been nascent, but the U.S. did appear to keep its engagement quiet, perhaps in order to stem any discourse that China was in fact gaining in this area. 
To demonstrate this, the chapter will first explore theories behind relative gains concerns and how those concerns might have affected U.S. actions in Africa. Then, it will demonstrate the American attempt to enact countermeasures in a subdued manner, exemplified by a focus on diplomatic talks between the U.S. and China.

\section{$\underline{\text { Relative Gains Concerns }}$}

Relative gains concerns ${ }^{132}$ can become apparent when a state which feels insecure wonders how gains will be divided with another state. Will the state which gains more use that surplus to hurt the one which gains less? If so, absolute gains, even when each state will gain a large amount, will mean little to the disadvantaged state, since, in the end, its survival hangs in the balance (Waltz, 1979, p. 105). Cooperation is inhibited by refusal to accept deals that benefit the other more, and by constant comparison between the states (Snidal, 1991, p. 703-704).

John Matthews (1996) argued that the strength of relative gains concerns is influenced by whether or not additional gains in future rounds are anticipated. When this "cumulation effect" is in play, states must act on the assumption that the current winner will also take advantage of future wins. This in turn constrains cooperation. David Rousseau (2002) found that several beliefs contribute to the importance of relative gains, including having a realist outlook, perceptions about other states (i.e., states seen as economic or military threats create more worry about relative gains), and having an understanding of the context. Military threats that had an economic component were

\footnotetext{
${ }^{132}$ For more detailed information on relative gains, see Jervis (1976), Waltz (1979), Krasner (1983), Keohane (1984), Oye (1986), Walt (1987), Grieco (1990), Powell (1991), Snidal (1991), Wendt (1992), Mearsheimer (1994/5), Hasenclever et al. (1997), Werner (1997) and Keohane \& Nye (2001).
} 
distinguished by participants from economic threats with no military component, and individuals were capable of mixing strategies based on their beliefs and the context.

Christopher Fettweis (2010) argued that great powers exist in a zone of peace when they are unconcerned with relative gains among other great powers (p. 139). Relative gains, he argued, becomes an issue when potential military power might become kinetic, or active in the world. China, he predicted, will never convert its potential military power into kinetic power, because it would not need to as a great power (p. 139-140). However, it appears that the U.S. has been reluctant to accept China as a great power (for a variety of reasons, not least, its autocratic, non-democratic government and its non-transparent modes of operating), and so was susceptible to relative gains concerns regarding its global activities.

To this way of thinking, it appears likely that, as the U.S. began to experience economic and power losses in Africa, it may have come to feel insecure about China's relative position. This relative gains concern could be a first step on the way to broader status concerns, which will be explored in Chapter 7. At this point, insecurity was relatively nascent as leaders slowly began to see a connection between China's gains and America's losses in Africa. As such, the reaction appears to have been mild and focused primarily on bilateral talks with China, rather than more broadly directed at a global audience.

The next several sections will detail the losses the U.S. suffered in Africa during this period. 


\section{$\underline{\text { Economic Loss }}$}

Trade between Africa and China rose just as trade between Africa and the U.S. fell off. Total trade between Africa and China rose from \$166 billion (2011) to \$198 billion (2012) to \$210 billion (2013) (FOCAC, 2015). Total trade between Africa and the U.S. fell from $\$ 125$ billion (2011) to $\$ 99$ billion (2012) to $\$ 85$ billion (2013) to $\$ 73$ billion (2014) (U.S. Census, 2015).

Exports from AGOA-eligible countries to the U.S. fell from $\$ 72.4$ billion (2011) to \$25.6 billion (2014). These exports account for 1\% of U.S. imports (Bridges Africa, 2015). Africa’s trade with China and the U.S. are shown below in Table 5.

Table 5: African Trade with China and The U.S.

All figures are in U.S. dollars.

\begin{tabular}{|c|c|c|c|c|c|c|c|}
\hline \multicolumn{2}{|c|}{ Exports to China } & \multicolumn{2}{|c|}{ Exports to U.S. } & \multicolumn{2}{|c|}{$\begin{array}{c}\text { Imports from } \\
\text { China }\end{array}$} & \multicolumn{2}{|c|}{$\begin{array}{c}\text { Imports from } \\
\text { U.S. }\end{array}$} \\
\hline 2003 & 2012 & 2003 & 2012 & 2003 & 2012 & 2003 & 2012 \\
\hline$\$ 6 B$ & $\$ 59 B$ & $\$ 32 B$ & $\$ 66 B$ & $\$ 6 B$ & $\$ 65 B$ & $\$ 10 B$ & $\$ 32 B$ \\
\hline
\end{tabular}

Source: Drummond \& Liu (2013) and U.S. Census (2015). 
Yun Sun and Michael Rettig (2014) attributed much of the U.S. losses in African trade to the 2008 recession, when American oil consumption fell 9\% (from 20.7 million barrels per day in 2008 to 18.9 million in 2013), and the cost of oil fell from $\$ 140$ barrel to a low of $\$ 32$ barrel. This caused AGOA-country oil and gas exports to the U.S. to fall from $\$ 60$ billion to $\$ 20$ billion. Non-oil exports also fell, but at a much lower percentage (6\% compared to $66 \%$ for oil and gas).

These losses occurred despite the 10-year renewal of AGOA in 2015. Mwangi Kimenyi, director of the Africa Growth Initiative, said in 2012 that "a decline of the United States in Africa" was apparent, as it was "being edged out slowly by China, Brazil, Russia, and others." President Obama's initiatives, like Feed the Future, were too small to make an impact, especially in the face of a "declining commercial relationship in Africa, and China’s growing influence” (Butty, 2012).

\section{$\underline{\text { Power Loss }}$}

China's provision of alternative, "no-strings” aid and financing, has seriously eroded the U.S. ability to influence leaders through its own "strings-attached" aid. According to David White (2014) "longstanding spheres of influence" for the U.S. have been affected. Tanzania, for instance, utilizes American aid but has worked with China on "roads, power plants, a gas pipeline and a huge new port." Examples of power loss in Zimbabwe, South Africa, Sudan and Nigeria are shown below. 


\section{Zimbabwe}

The U.S. has attempted to shape Zimbabwe for decades, but efforts have increased since the year 2000, with a focus on human rights, rule of law and democracy. The Zimbabwe Democracy and Economy Recovery Act, passed in 2001 by the U.S. Congress, restricted the kinds of assistance the U.S. could vote for in international financial institutions. Sanctions have been applied to certain people and entities since 2001. However, the U.S. has continued to provide millions of dollars in aid, mostly for health programs, agriculture, humanitarian assistance, democracy, rule of law and human rights (Embassy of the United States, Zimbabwe, 2015). The Department of State says that it “took a leading role” against violations by the Zimbabwean government from 2000 - 2008. The elections of 2013 were considered "flawed" and unrepresentative of the will of the people. "We have made it clear that the easing of restrictive measures, including targeted sanctions and travel bans, will only occur in the context of credible, transparent, and lasting democratic reforms,” said the U.S. Department of State (2015). Zimbabwe reflects the U.S. fight for influence to install democracy in Africa, which is highly complicated by China’s involvement with this state. U.S.-Zimbabwe trade is about $\$ 50$ million annually, while China-Zimbabwe trade is about \$1 billion (The Mail \& Guardian, Eight Myths, 2015). Zimbabwe's President, Robert Mugabe, in power since 1987, was also appointed the Chair of the African Union and the Southern African Development Community (SADC) in January 2015. Mugabe was awarded the Confucius Peace Prize by China in 2015, although he refused to accept it after learning it was not connected to the Chinese government. 


\section{South Africa}

The U.S. had a difficult relationship with South Africa because of apartheid and minority white rule even into the 1990s, when sanctions were finally lifted and the U.S. began sending aid. Relations were then strained by the presidency of Thabo Mbeki (1999 - 2008), as he had fears of CIA activities in his country and refused to work with the U.S. in stamping out AIDS. The election of Kgalema Motlanthe in 2008 provided a fresh start for the two, and the U.S. made it clear that South Africa was key to resolving the issues in Zimbabwe. Passage of AGOA also smoothed the relationship, as did the signing of a Trade and Investment Framework Agreement (TIFA) in 1999 and 2012. Trade between the U.S. and South Africa was \$21 billion in 2012; it was \$32 billion between China and South Africa (Ensor, 2014).

However, the relationship has suffered. South Africa objected to both the 2011 bombing of Libya as “regime change” and to freezing $\$ 1.5$ billion of the Gaddafi regime’s assets in the United Nations. In the same year, South Africa insisted on importing Iranian oil, over U.S. objections. Further, South Africa has viewed itself as a "champion of the Global South," sympathetic toward "countries that exert their independence from the West” (Firsing, 2012). Involvement in BRICS projects, like the New Development Bank, has showcased this separation from the U.S., and aligned it very clearly with China. The U.S. does not need to effect major change in South Africa, but finds a powerful challenge there nonetheless. 


\section{Sudan}

Sudan has been ground zero for tussles between the U.S. and China. The U.S. designated Sudan a state sponsor of terrorism in 1993 and closed its embassy there in 1996, reopening it in 2002. Sanctions were applied in 1997 and 2007. The Darfur conflict began in 2003, when non-Arabs rebelled against the Sudanese government, and were put down by Arab militias, called Janjaweed. Three hundred thousand have been killed and 2.5 million internally displaced since then. The U.S. was heavily involved with the 2005 Comprehensive Peace Agreement (CPA) between Sudan and the Sudan Peoples' Liberation Movement (SPLM), and with the 2011 South Sudan independence referendum. It continues to be involved in resolving issues between North and South Sudan. The U.S. has provided \$7.1 billion in assistance to Sudan from 2002 to 2015; however, none of the assistance has gone directly to the Government of Sudan. The U.S. has indicated it would like better relations with Sudan, but that it must first provide human rights protections and democracy for its citizens. Sudan has accused the U.S. of "moving the goalposts" on improving relations; the U.S. has replied that "war and widespread human rights violations have impeded our efforts” (Sen, 2012). Sudan signed a Trade and Investment Framework Agreement (TIFA) in 2001; however, it is not eligible for AGOA. U.S. trade with Sudan was \$98 million in 2013.

China has been very active in Sudan. It is the largest trading partner and owns 40\% of Sudanese oil projects through its state-owned China National Petroleum Corporation. It is not, however, the major arms supplier (Russia makes up the vast majority). Sudanese President Omar al-Bashir actively sought alternatives to U.S. support after sanctions were imposed. He said: 
From the first day, our policy was clear... To look eastward, toward China, Malaysia, India, Pakistan, Indonesia, and even Korea and Japan, even if the Western influence upon some [of these] countries is strong. We believe that the Chinese expansion was natural because it filled the space left by Western governments, the United States, and international funding agencies. The success of the Sudanese experiment in dealing with China without political conditions or pressures encouraged other African countries to look toward China (World Public Library, 2015).

Al-Bashir visited President Hu Jintao in Beijing in 2010 and was received as "friend and brother” (World Public Library, 2015). Former child soldier and Sudanese hip hop star Emmanuel Jal said about China:

[They] don't influence our politics. They don't comment on it, and what they want, they pay for - sometimes double the amount. This tends to make all Africans happy... there isn’t a party in Africa that doesn’t like them. Even if you're a rebel movement and you say to them you can secure gold, the Chinese will simply say they want to buy it. The only foreign policy advice I heard from China was when they said to Sudan: ‘Don’t go back to war.' That's all they said. They didn’t push anything else” (Shadbolt, 2011). China has provided humanitarian aid (\$21 million in 2014) and increased its peacekeepers, including combat troops, to the region. Sudan has tested China's noninterference stance to the limits (Fielding, 2015). Total trade between China and Sudan was approximately \$3.4 billion in 2014 (U.N. Comtrade, 2015). 


\section{Nigeria}

Nigeria is Africa’s most populous country and has massive reserves of oil and gas. U.S.-Nigeria relations improved after the 1999 election of Olusegun Obasanjo but continue to face issues of terrorism, particularly with Boko Haram, ${ }^{133}$ sectarian conflicts, corruption, poverty and ineffective government services. The U.S.-Nigeria Binational Commission, founded in 2009, focuses on governance, transparency, energy and investment, regional security, the Niger Delta, and agriculture and food security. The U.S. has been involved in providing military aid to fight Boko Haram, but has had a difficult time dealing with the Nigerian government on the issue. The Pentagon has admitted to sometimes evading Nigeria and choosing to work with neighboring countries instead. "We don't have a foundation for what I would call a good partnership right now,” said an official with AFRICOM in 2015 (Cooper, 2015). U.S. trade with Nigeria has been primarily in petroleum/mining and wholesale products, although there is some agricultural trade. Nigeria is eligible for AGOA (Department of State, 2014). Total trade between the U.S. and Nigeria was $\$ 9.8$ billion in 2014 (UN Comtrade, 2015).

China-Nigeria relations became much stronger in the 2000s, after FOCAC meetings and visits by President $\mathrm{Hu}$ Jintao. The two signed a memorandum of understanding on strategic partnership in 2006. China helped Nigeria to launch a communications satellite in 2007, and has supported Nigeria’s bid for a seat on the U.N. Security Council. Total trade between China and Nigeria was \$18.05 billion in 2014 (U.N.

\footnotetext{
133 Boko Haram is an Islamic extremist group founded in 2002 which has pledged allegiance to the Islamic State of Iraq and the Levant (ISIL). It is responsible for a number of attacks and mass kidnappings, more than ten thousand deaths and the displacement of 1.5 million (Sergie \& Johnson, 2015). See also Comolli (2015) "Boko Haram: Nigeria’s Islamist Insurgency,” and Pham (2012) “Boko Haram’s Evolving Threat.”
} 
Comtrade, 2015). In total trade, Nigeria makes up 6.2\% of China’s Africa trade; and a third of trade between China and West Africa. About 87\% of Nigeria's exports to China are oil and gas resources. In 2000, Nigeria provided 7.4\% of China’s oil from Africa, and in 2010, it provided 2\% (other African countries had begun providing oil as well). Angola and Sudan have been and remain the top suppliers. China has also created the Lekki and Ogun Guangdong Free Trade Zones, and established Confucius Institutes at the Nnamdi Azikiwe University and the University of Lagos (Egbula and Zheng, 2011, p. 6-7; 13-17).

\section{American Hegemonic Decline}

In the post-Cold War period, the U.S. appeared to perceive itself as strong enough to act unilaterally, and often refused to work with international institutions like the United Nations. The Iraq War was the epitome of this kind of thinking. ${ }^{134}$ For a brief period of time (2005 - 2006) Secretary of State Rice championed an idea called "transformational diplomacy,” which involved addressing foreign policy problems related to U.S. interests, while strengthening state capacity to deal with the problems internally, and attracting other major powers to help (Rice, 7/25/05). Rice later clarified that the goal was to convert countries into "democratic, well-governed states that will respond to the needs of their people and conduct themselves responsibly in the international system” (Rice, 2/15/06). This idea, or at least the specific labeling of it as "transformational," was soon dropped. Cognizant of the need for global assistance on terrorism and of general international

\footnotetext{
${ }^{134}$ See also Liska (2003), Fouskas and Gokay (2005), David \& Grondin (2006), Schacke (2009), and Rozell \& Whitney (2009).
} 
displeasure with certain U.S. actions, American hegemony was sometimes downplayed or tempered by being equated with universal values. ${ }^{135}$

The Obama administration was somewhat humbled by the precipitous fall in U.S. popularity during the previous Bush administration, and so tended to speak in terms of universal values (which also happened to be American). ${ }^{136}$ While understanding the need to act within a multilateral world, the Obama administration nevertheless continued to behave as a global hegemon, the most powerful nation in the world. ${ }^{137}$ Secretary Clinton's "smart power" was the new way of discussing U.S. hegemony. In 2010, she said that while the "interconnection" of the world has brought countries "superficially closer together," it in fact meant it was "the intensity of the demand on the United States to be able to respond and lead" that was increased. "Smart power is not just a slogan," she continued. Leadership meant being able to "provide incentives" for states that even recently would not have thought they had responsibility in the system, and "disincentives" for those which refused to help (Clinton, 5/27/10).

In 2011, Clinton called the U.S. “exceptional” for its “creativity and openness,” still a "beacon of freedom, a guarantor of global security, a true opportunity society..." (Clinton, 9/9/11). In September of 2008, in a meeting between President Bush and President Kufuor of Ghana, Kufuor hinted at the loss of American supremacy:

The world is in flux now... All the nations are moving forward and asserting

\footnotetext{
${ }^{135}$ See Rice (7/3/03, 12/20/07, 9/23/08).

${ }^{136}$ See Obama (9/23/10, 9/25/12).

${ }^{137}$ See also Parmar, et al. (2014), Clingan (2013), and Norrlof (2013).
} 
themselves to share in power. Until, say, about 20 years ago, the world was divided on a bipolar basis -- two superpowers. Now, since then, the United States shot up as the unipolar power. But so soon, even the United States must cede this place of power to the rest of the world... If humanity would hold its place, it seems all of U.S. might begin to share together -- to move together into the global village. And the movement should be on the backs of science and technology, in which the United States is still the leader. We look up to the leadership of the United States to perhaps develop a new vision for the global village... When you are a leader in such a situation, such a flux, naturally you suffer many knocks all over the place. And the perhaps highest quality expected of the leader is to stay the rough and tumble of the changes that must be faced. And I believe this leader is doing very well, in spite of the many challenges that engulf him now (Kufuor, 9/15/08).

Christopher Layne (2012) wrote in the Atlantic that "when great powers begin to experience erosion in their global standing, their leaders inevitably strike a pose of denial.” Denial had been seen in the fall of the British empire and could be seen today, from Secretary Clinton’s “new American moment” of 2010 to Obama’s State of the Union speeches flatly asserting continued American hegemony. Layne agreed with Stephen Walt's assessment that the “American Era” was ending, although the U.S. would retain its position as the strongest state for some amount of time in the near future.

The waning of influence came not just from China’s rise, but, Walt argued, from 
the loss of manufacturing superiority, the difficulty in maintaining military superiority through lack of available dollars, and from competition from other countries, like China. Further, the U.S. could no longer "shape the international order through influence, example and largesse” after the 2008 recession.

It will be increasingly important for the U.S. to "manage the transition" away from hegemony, as its dominance - and that of the West - fades. In the near term, it appears that the worst threats are from a "bleak fiscal outlook" and uncertainty about whether the dollar would remain the foremost international reserve currency. An increasing difficulty in "discharging hegemonic tasks" like providing global public goods in the form of a strong international economic order, reserve currency, and a thriving market for others' exports, is likely, creating a power vacuum. The U.S. will face the "Lippmann gap,” meaning it must "bring commitments into balance with the resources available to support them while creating a surplus of power in reserve.” Offshore balancing is the likeliest response. This would involve prioritizing global regions, shifting the burden of protection to other states, and relying on naval and air power.

Americans themselves appear to believe that U.S. global influence is waning. In a 2013 Pew poll on America's place in the world, a majority (53\%) of adults surveyed believed "the United States plays a less important and powerful role as a world leader than it did a decade ago.” The total was just $20 \%$ in 2004 . This was the first time since the inception of the survey 40 years ago that a majority have had this opinion. Seventy percent of those surveyed also believed the U.S. is "less respected than in the past," up from $56 \%$ in 2012. Fifty-two percent said the U.S. "should mind its own business internationally and let other countries get along the best they can on their own.” This does not extend to trade 
relations with other countries, as $77 \%$ said these ties are very good or somewhat good, and $66 \%$ believed that involvement in the global economy was good. Americans' top foreign policy priorities were preventing terrorist attacks (83\%) and protecting American jobs (81\%). A near majority, 48\%, believed China was the world's leading economic power, while $31 \%$ believed it was the U.S. Sixty-eight percent believed the U.S. was the world's leading military power, while $14 \%$ believed China had overtaken the U.S.

However, it appears the U.S. has lost standing in Africa. Gallup's World Poll, launched in 2005, has reflected the ups and downs in Sub-Saharan Africa's approval of U.S. leadership. After the election of President Obama in 2008, approval ratings were as high as $75 \%$ in some African countries. These high ratings fell precipitously, especially in Eastern Africa, as shown in Table 6, below. 
Table 6: African Approval of the United States, 2009 - 2014

\begin{tabular}{|l|c|c|}
\hline Region & $\begin{array}{c}\text { Approval of U.S. } \\
\text { Leadership in 2014 }\end{array}$ & $\begin{array}{c}\text { Change in Approval of } \\
\text { U.S. Leadership, 2009 - } \\
\mathbf{2 0 1 4}\end{array}$ \\
\hline EASTERN AFRICA & 58 & -35 \\
\hline Kenya & 49 & -40 \\
\hline Tanzania & 48 & -43 \\
\hline Uganda & & \\
\hline WESTERN AFRICA & 70 & -18 \\
\hline Cameroon & 54 & -26 \\
\hline Ghana & 60 & -10 \\
\hline Nigeria & & -29 \\
\hline SOUTHERN AFRICA & 58 & -9 \\
\hline South Africa & & -7 \\
\hline SAHEL & 77 & -18 \\
\hline Chad & 60 & -6 \\
\hline Mauritania & 65 & \\
\hline Niger & 81 & \\
\hline Senegal & & \\
\hline
\end{tabular}

Source: Rheault and McCarthy, Gallup (2015).

Quiet Diplomatic Countermeasures by The U.S.

It appears that, despite the way U.S. leaders downplayed the significance of Chinese activities in Africa, as seen in the previous chapter, after 2005 they were beginning to see these activities as a source of loss for America, calling relative gains concerns into play. While the U.S. may have begun to perceive some level of status competition, it appears to have found the greater issues to be the loss of access to resources, and the handicapping of its traditional focus on the continent (to provide aid, promote democracy, and so on). 
The next section will detail the diplomacy the U.S. engaged in as it began to connect its own losses in Africa to Chinese activities there. The next chapter will show how the U.S. decided to act once it had moved beyond relative gains concerns and into a deeper perception of status competition with China.

\section{U.S.-China-Africa Trilateral Meetings}

In 2006 and 2007, three trilateral meetings were held among the U.S., Africa and China, the result of efforts by The Brenthurst Foundation, the Chinese Academy of Social Sciences, the Council on Foreign Relations, and the Leon H. Sullivan Foundation. ${ }^{138}$ One report, titled Africa-China-U.S. Trilateral Dialogue Summary Report, issued by these groups in 2007, summed up the three meetings which had occurred; its expressly stated purpose was to show that:

There is no inherent strategic conflict between China and the United States in Africa, and that Sino-American cooperation in Africa is not only possible but it is in the interests of all stakeholders who seek to promote Africa's development and integration into the global economy (p. 2).

However, the summary of the first meeting stated that "a rising China will have a profound effect on Africa and on how the United States interacts with countries south of the Sahara" and that the "prevailing wisdom" was that Chinese activities in Africa presented "both opportunities and challenges" (p. 8). The dialogue was called "candid in

\footnotetext{
${ }^{138}$ Meetings were held in Tswalu, South Africa (August 2006), Beijing (March 2007) and Washington, DC (September 2007).
} 
identifying differences in policies and methods of operation between China and the United States” (p. 9).

The major issues that emerged included globalization, democratization and governance, peace and security, corporate social responsibility, Chinese-American cooperation, and the future. Globalization was seen as the basis for rising investment in Africa from around the world, putting Africa "in play" commercially. Meeting members called resource competition between the U.S. and China "remote" but said they shared an interest in a stable Africa. Participant Princeton Lyman believed that differences in active sectors between the Chinese and U.S. did not amount to a "strategic conflict." Further, Chinese activities in the energy sector would benefit the world by adding to the supply. And, he added, U.S. firms were used to business competition, at home and abroad (p. 10). Other participants did note that some in the U.S. saw Chinese activities in Africa as "part of a broader strategic rivalry between the two countries" and that competition could become more intense in the energy sector (p. 10). The Chinese delegate warned that China "needs space to go out into the world because of its large population" and that the U.S. must be careful not to be seen as “thwarting China’s economic development” (p. 10).

Disagreement arose over the role of democracy and governance, with the U.S. finding it critical and China sticking to non-interference and "consensus politics,” calling democracy sometimes “destabilizing.” Darfur was approached, more from the American side in earlier meetings, but later from the side of the Chinese, who stressed their peacekeeping commitments there. Regarding corporate social responsibility, it was noted that U.S. interests in Africa remained mostly in resources, while China was branching out into other sectors. The U.S. brought up "internationally developed codes of conduct” which 
the Chinese found "interesting" but noted they "had not been a participant in their development and would have to examine them further" and that they were perhaps not well-suited to on-the-ground realities. As far as cooperation between the U.S. and China, agriculture, health and peacekeeping were seen as key areas to explore (p. 2-4).

The dialogue was described by the report as creating "a sense of common trust based on a shared commitment to accelerating Africa's economic development” as the "cornerstone" of the meetings. By putting Africa in the center, the report argued, talks were moved "away from an undue emphasis on Chinese and American competition in Africa" toward ways "Africa could gain from the attention of both countries" (p. 4). It was emphatically stated that "there [was] no strategic conflict between the U.S. and China in Africa, and there is no zero-sum dynamic between the two countries." Further, a new “scramble for Africa” must be avoided (p. 5). U.S. and China’s “divergent interests” would not lead to automatic cooperation, but could be "reconciled to Africa's benefit." Business competition between the two was seen as potentially positive, but should take place across a variety of sectors, not just natural resources (p. 5).

It became clear that the objectives of all three regions for Africa (the U.S., China and Africa) were quite different, with the U.S. focused on governance and peace, China on peace and development and Africa on development and poverty alleviation (p. 6). The way forward was seen to include establishment of an official trilateral mechanism, perhaps through the African Union, and a forum for U.S.-Chinese cooperation, bringing together stakeholders in African sectors, and continuing to work on peacekeeping (p. 7). This did not occur in the following years. 
These trilateral talks were an attempt by the U.S. to openly talk with both the Chinese and the Africans about activities there. Discourse was subdued, as evidenced by repeated assurances that there was little to no competition, conflict or rivalry between the U.S. and China. The talks were specifically meant to move the conversation away from the idea of U.S.-China competition in Africa. It appears officials believed at that point that China could be convinced to change its behavior, especially if all talk of competition could be eliminated. While both sides remained entrenched in their positions, the U.S. would continue diplomatic talks with China, as seen in the next section.

\section{U.S.-China Diplomatic Talks}

In 2005, Assistant Secretary of State for African Affairs Jendayi Frazer traveled to Beijing specifically to discuss U.S.-China cooperation over Africa. Her conclusion at the time was that she did not think that Chinese activities in Africa were in "direct competition" with those of the U.S. In March 2007, Frazer met with Chinese officials to discuss debt, peacekeeping, conflict resolution, and Chinese firms' activities in the extractive industries. The outcome appeared to be a desire to cooperate over Africa, although the two could not seem to find projects to actually collaborate on (Morrison and Cooke, 2009 and Pham, 2006). In 2008, Frazer visited Beijing to discuss cooperation in infrastructure, agriculture and health, and to recommend aid coordination (Eisenman and Shinn, 2008). She expressed concern over China's lending practices and failure to endorse the Extractive Industries Transparency Initiative (EITI). In 2008, U.S. State Department officials testified that Chinese activities in Africa were a "potentially positive force for economic development"

and did not see that there was any lessening of U.S. influence there. The Department of the 
Treasury, meanwhile, was more focused on the problems it found in Chinese lending practices (China in Africa, 2008).

In a 2008 hearing before the Senate Subcommittee on African Affairs on China in Africa, Stephen J. Morrison said:

We've underestimated in... these dialogues the resistance that we see on both sides... Both the United States and China are very preoccupied with... moving forward their expansive engagement in Africa, which is historic for both of them... They also are very concerned about branding and sovereign identity... The Chinese are getting into Africa with an argument they are different from the West. Their motivations are not to dilute that line through too close an integration of their efforts with ours. We have to get smarter about how we frame this so that we can make the case that neither of us are going to dilute what we're really trying to do here, in terms of promotion of comparative national interests. The United States has a certain sensitivity also about this seeming neocolonial. And I think that interest can be ameliorated to the degree that more and more African participants are integrating into these discussions. To the degree that these are China and Africa’s policymakers talking about Africa, it does have this odd outdated appearance to it, even while there may be important business to discuss (p. 43).

In 2010, Secretary Clinton acknowledged that China’s presence in Africa had been addressed with China, by looking into their activities, being open, and seeking ways to cooperate (Clinton, 5/27/10). Deputy Assistant Administrator for USAID Rajakumari 
Jandhyala, in a written response to questions posed by Senator Coons under a 2011 hearing by the Senate Subcommittee on African Affairs assessing the fiscal year 2012 budget for Africa, detailed the ways the U.S. has engaged China around the issue of Africa, including through high-level talks, such as the U.S.-China Strategic and Economic Dialogue and the U.S.-China Sub-Dialogue on Africa, and multilaterally through the Organization for Economic Cooperation and Development (OECD) Development Assistance Committee. Although the Chinese had made a verbal agreement to collaborate with USAID, headway had been lethargic.

Further, Jandhyala said, USAID Administrator Rajiv Shah met with China's Ministry of Health, Division of International Cooperation staff, and reached an agreement to hold a joint assessment on health in Ghana and Liberia. The report was presented at the China-Africa International Health Conference in 2011. The overarching goal was to grasp Chinese foreign aid goals and methods in order to align them with U.S. goals and methods.

Also in 2011, USAID and the State Department put on a food security and agriculture workshop in China, where discussions on collaboration were held. Jandhyala urged the Chinese to take part in the Extractive Industries Transparency Initiative, World Health Organization recommendations, the 2005 Paris Declaration on Aid Effectiveness, and the 2008 Accra Agenda for Action (p. 80).

Throughout this period, the U.S. continued to attempt to talk to China about Chinese activities, and to try to get some kind of cooperative project off the ground. Morrison's 2008 testimony, discussed above, is most instructive as to the difficulty of this tactic. China was in fact moving forward with its engagement in Africa, and would not be put off or stopped by American consultations, nor would it lessen its impact by doing 
projects the Americans wanted done. In fact, making it even less likely that dialogue would change the Chinese was the fact that they were expanding based on their differentiation from the West, and the U.S. It appears this phase of American reaction was doomed to fail. The combination of failed diplomacy and recognition of loss in Africa, pushed the U.S. to the next phase in the development of its reaction.

\section{Conclusion}

In this chapter, the third outcome of this case study was explored, which is that, during the period 2005 - 2011, the U.S. began to experience relative gains concerns about Chinese activities in Africa. This occurred as it began to see not only economic and power losses in Africa, but also a global hegemonic decline. While discourse did not change, the mild, bilateral diplomatic measures the U.S. took to address these concerns are a key to understanding the American reaction to China. These relative gains concerns appear to have been a first step on the way to greater status competition, which will be explored in the next chapter.

The next chapter will examine the fourth and final outcome of this case study, which is that, beginning around 2011, the U.S. appears to have begun to perceive Chinese activities in Africa as more than just those of an economic competitor, with consequences greater than simply blocking traditional American activities in Africa. For the first time, the U.S. seemed to perceive Chinese activity as a status threat. In reaction, from 2011 to the present, the U.S. launched a public campaign to win African leaders and publics back from China; in doing so, it positioned itself as opposed to the values of China and as a 
better partner. Importantly, it seems the U.S. did this not because its view of the value of Africa had changed, but rather as a form of status competition with China. 


\section{CHAPTER SEVEN: TAKING ACTION ON STATUS CONCERNS}

\section{$\underline{\text { Introduction }}$}

In the previous chapter, the third outcome of this research study was explored, which is that, in the period 2005 - 2010, U.S. leaders became somewhat concerned about Chinese activities in Africa, and began to take subtle diplomatic countermeasures. Public discourse did not change during this period, but it appears that the quiet American reaction was related to a change in perception about the nature of Chinese activities in Africa. The U.S. seemed to have begun to notice economic and power loss in Africa, especially in its ability to shape African leaders’ actions, triggering relative gains concerns. However, status competition with China was not yet a major concern.

This chapter examines the fourth and final observed outcome of this research study, which is that around 2011, the U.S. appears to have begun to perceive Chinese activities in Africa as more than just those of an economic competitor, with consequences greater than simply blocking traditional American activities in Africa. For the first time, the U.S. seemed to perceive Chinese activity as a status threat. In reaction, from about 2011 to the present, the U.S. appears to have launched a public campaign to win African leaders and publics back from China; in doing so, it seemed to be positioning itself as opposed to the values of China and as a better partner. It appears the U.S. did this not because its view of the value of Africa had changed, but rather as a form of status competition with China.

This chapter will show how it appears the U.S. used discourse, public diplomacy and a summit to win African publics away from China. It will also show how the U.S. positioned its “brand” and messaging to oppose China’s distinctive characteristics and 
methods, and how the U.S. specifically sought to be seen as "a better partner" than China. Then, the chapter will show that these activities seem to be related to status, as (1) Africa offers little for the U.S. to gain economically, despite the recent "Africa rising” narrative and (2) the U.S. domestic public continues to seem generally unconcerned with Africa.

\section{Winning The Public Over}

\section{Public Diplomacy}

As discussed in Chapter Two, Literature Review, public diplomacy is used by governments to influence the opinions and attitudes of foreign publics. The "new" form involves engagement with these foreign publics, rather than simple provisioning of information, and the goal is to form a trusting relationship. More and more, governments are turning to digital media to engage their audiences. This section examines how the U.S. might have used public diplomacy to reach African audiences in order to influence them away from China.

The belief surrounding public diplomacy during the Bush Administration was that the world simply did not understand the "goodness and compassion and generosity of the American people" or their faith in the power of international institutions and the rule of law. These foreign publics seemed unaware of the number of American deaths endured while defending them. 
It was thought propaganda, myths and lies were responsible for some foreigners' low opinion of the U.S. Changing this would be accomplished via exchanges, learning other languages and accepting foreign cultures (Rice, 3/14/05). By 2008, Secretary Rice touted high U.S. popularity in China and India several times, and said: "[The U.S.] should seek respect. It should seek a reputation for standing for the right values” (Rice, 12/9/08, CBS News Radio, 12/9/08, NPR, 12/21/08).

Assistant Secretary Carson said in 2009 that "the blood of Africa flows in the veins of America" and that "mutual engagement" of the U.S. and African publics had driven the relationship along with foreign policy. Africans have generally had a "benign and positive" experience with the U.S., benefitting from its "teachers, missionaries, nurses, doctors, and students who tended to live among Africans and learn their languages in sharp contrast to European colonialists," he concluded. Specifically mentioning public diplomacy, Carson praised the Fulbright program, technical assistance from USAID, English language lessons, and more. All this had shown Africans "a vision of America that is sophisticated, accessible, humane, and that welcomes them with open arms” (Carson, 6/25/09). President Obama’s 2009 visit to Ghana was underscored by a focus on public diplomacy and smart power. However, general American neglect of Africa before 2012 affected U.S. public diplomacy efforts in Africa, with the exception of some on-the-ground "public diplomacy 2.0."139

\footnotetext{
139 These efforts have included the early adoption of Twitter and Mixit by the U.S. Embassy in Pretoria; an Africa Regional Media Hub in South Africa; a crowd-sourced website for testimony by women victims of the war in the Democratic Republic of the Congo by Voice of America; and the Apps4Africa business challenge (Center for Public Diplomacy Blog, 2013). Some U.S. embassies in Africa also offer public diplomacy awards.
} 
The State Department’s blog, DipNote, which feeds State Department Facebook and Twitter accounts, began posts on Africa in 2007. Below are the number of posts per year on this site for the Africa region, by major categories, from the years 2007 - 2014 (State Department, DipNote, 2015). 
Table 7: U.S. State Department Social Media On Africa, 2007 - 2014

\begin{tabular}{|c|c|c|c|c|c|c|c|c|c|c|c|}
\hline Year & $\begin{array}{c}\text { Total \# } \\
\text { of } \\
\text { Posts }\end{array}$ & Health & Conflict & $\begin{array}{c}\text { Food } \\
\text { Security }\end{array}$ & Economy & $\begin{array}{c}\text { Youth, } \\
\text { Education } \\
\text { \& Gender } \\
\end{array}$ & $\begin{array}{c}\text { Energy, } \\
\text { Environment } \\
\text { \& Wildlife } \\
\end{array}$ & $\begin{array}{c}\text { Democracy } \\
\& \\
\text { Governance } \\
\end{array}$ & $\begin{array}{l}\text { Poverty } \\
\text { \& Aid }\end{array}$ & $\begin{array}{c}\text { State } \\
\text { Meetings \& } \\
\text { Summits }\end{array}$ & $\begin{array}{c}\text { Other } \\
140\end{array}$ \\
\hline 2007 & 6 & 0 & 4 & 0 & 0 & 0 & 0 & 0 & 0 & 1 & 1 \\
\hline 2008 & 39 & 0 & 10 & 0 & 2 & 1 & 1 & 7 & 0 & 9 & 9 \\
\hline 2009 & 28 & 1 & 10 & 2 & 1 & 1 & 2 & 2 & 0 & 5 & 4 \\
\hline 2010 & 72 & 9 & 18 & 2 & 9 & 8 & 3 & 4 & 0 & 2 & 17 \\
\hline 2011 & 182 & 22 & 54 & 15 & 13 & 15 & 5 & 3 & 2 & 13 & 40 \\
\hline 2012 & 91 & 8 & 11 & 13 & 11 & 14 & 5 & 3 & 0 & 11 & 15 \\
\hline 2013 & 80 & 6 & 9 & 8 & 6 & 12 & 5 & 4 & 1 & 9 & 20 \\
\hline 2014 & 132 & 34 & 30 & 11 & 16 & 11 & 5 & 8 & 0 & 5 & 12 \\
\hline
\end{tabular}

140 Other includes general public diplomacy efforts, blogs by embassy workers, round ups of posts, and other items that do not fit the general categories. 
The total number of posts on Africa spiked in 2011, fell in 2012 and 2013, and then rose in 2014, as shown in Figure 4, below. This uptick in posts in 2011 correlates with the idea that the U.S. wanted to be seen as giving more attention to Africa and African issues once it recognized that it was losing status to China there.

Figure 4: Total Number of Posts On Africa by Year

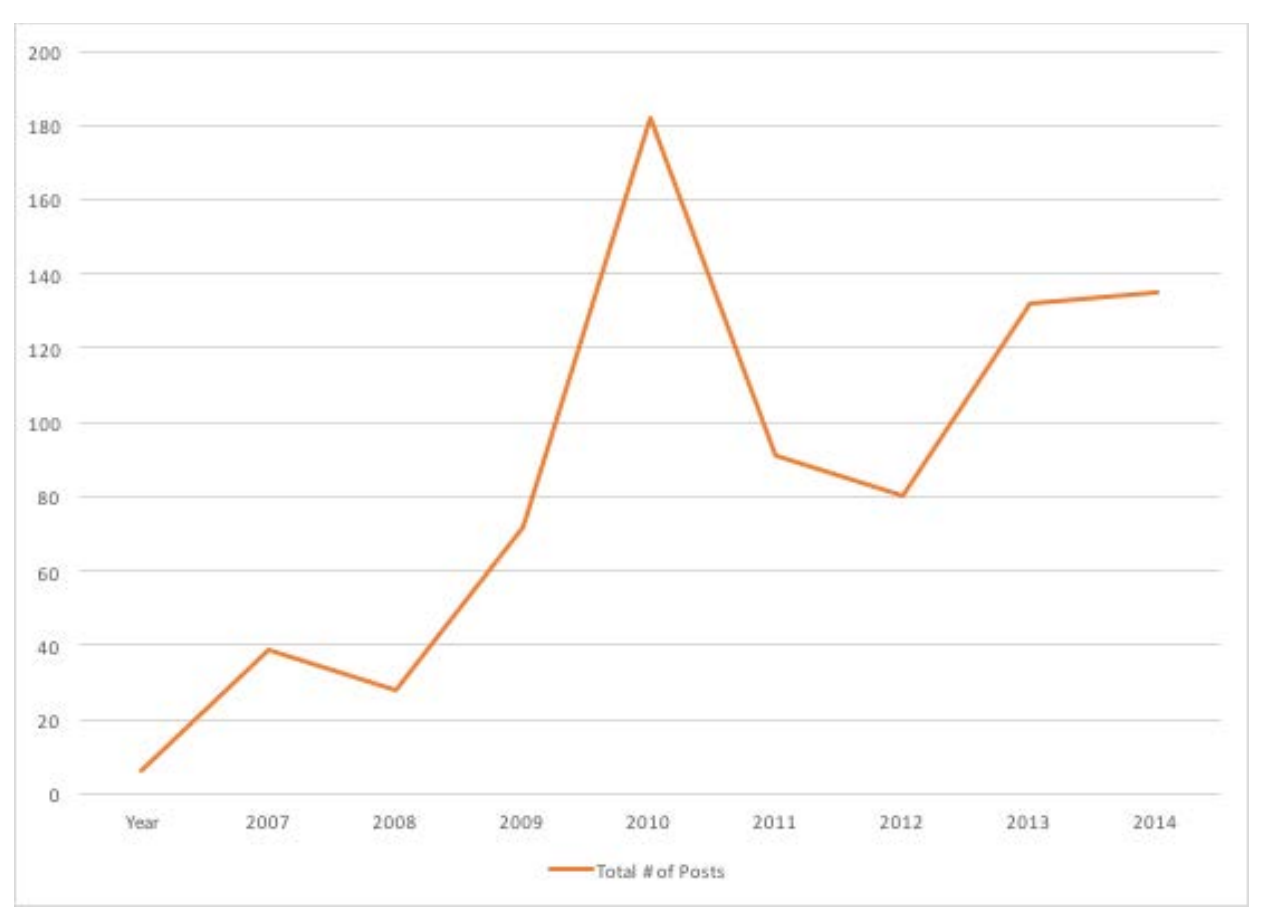

As shown in Figures 5 and 6 below, there was a significant ramp up of posts in the period 2011 - 2014. In Figure 5, the number of conflict-related messages was greatest (42), with state meetings coming in a distant second (17). Democracy (13) and the economy (12) were even farther behind. In Figure 6, while the number of conflict-related messages stayed very high (102), health (70), youth (52), food security (47) and the economy (46) were also were highly publicized categories. These clearly reflect American involvement in conflict reduction and the Ebola outbreak. However, the youth, food security and economy 
messages reflect policy changes, which will be seen later in this chapter. These changes are significant in that they point to increased messaging perhaps designed to (1) show that the U.S. had something to offer Africa, (2) that the U.S. was a good partner, and (3) differentiate the U.S. from other states Africans were dealing with. 
Figure 5: Social Media Posts by Category, 2007 - 2010

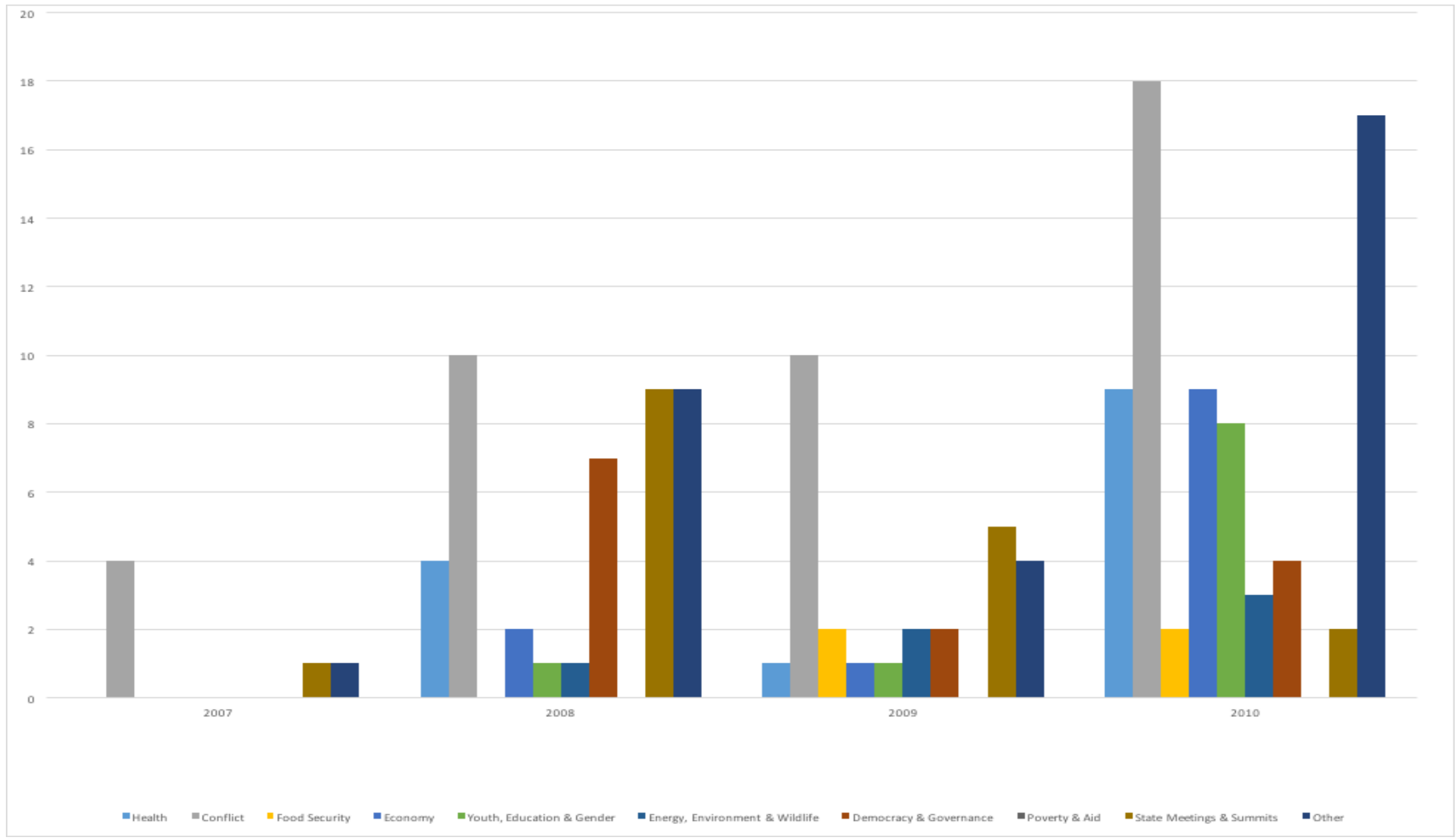


Figure 6: Social Media Posts by Category, 2011 - 2014

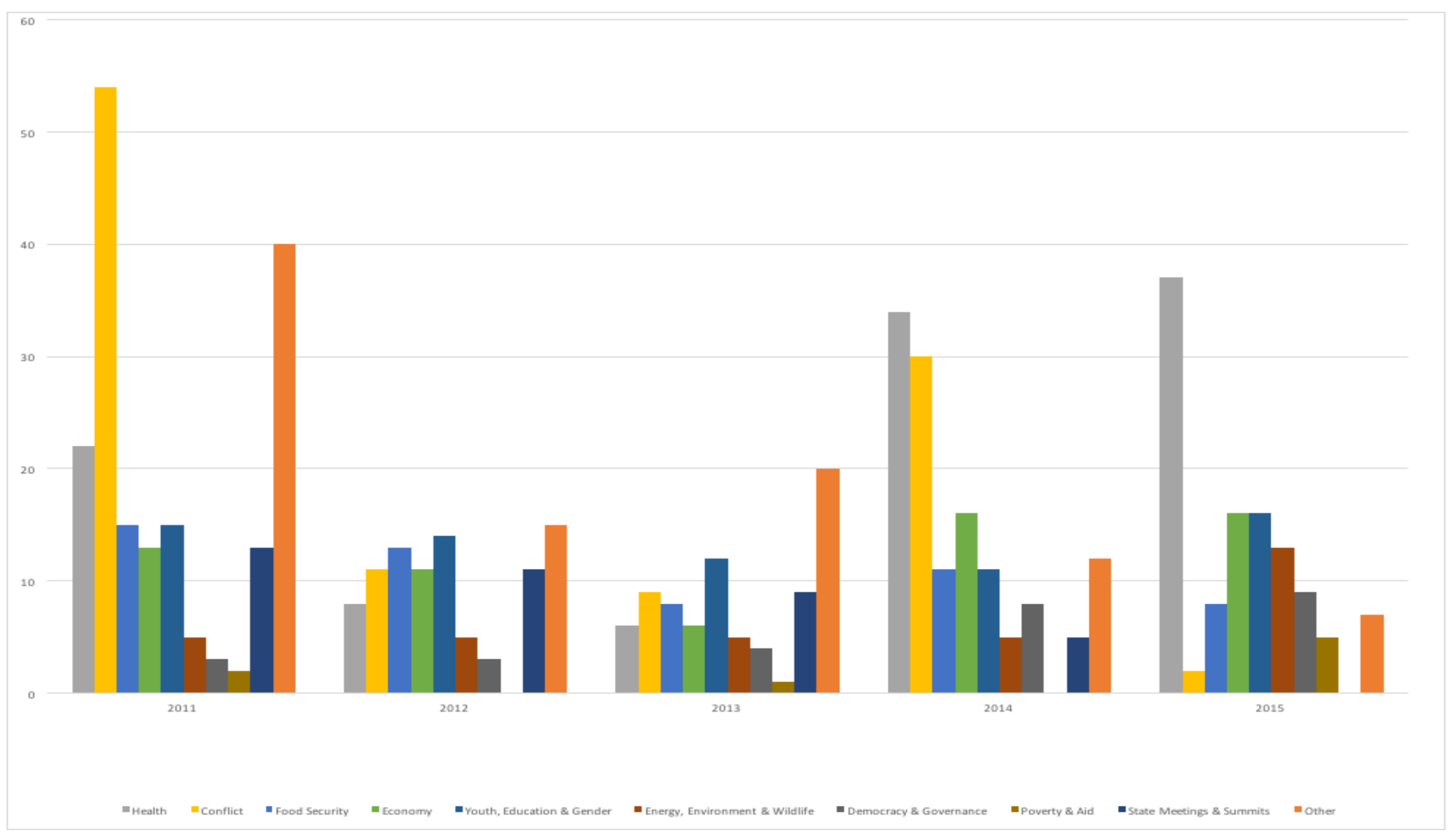


The 2014 Comprehensive Annual Report on Public Diplomacy and International Broadcasting by the United States Advisory Commission on Public Diplomacy, shows that the public diplomacy budget for Africa had increased by about $20 \%$ over the past three years (p. 102). Countries/regions with allocations of more than $\$ 1$ million are shown in Table 8 below. 
Table 8: State Department Public Diplomacy Budget, 2013 - 2014

In millions of U.S. dollars

\begin{tabular}{|l|c|c|c|}
\hline Country & $\begin{array}{c}\text { FY 2013 } \\
\text { Allocation }\end{array}$ & $\begin{array}{c}\text { FY 2014 } \\
\text { Allocation }\end{array}$ & $\begin{array}{c}\text { Percent } \\
\text { Change }\end{array}$ \\
\hline Africa Total & 32 & 36 & +4 \\
\hline Africa Regional Services & Not Available & 2.78 & - \\
\hline $\begin{array}{l}\text { Voice of America Broadcasting } \\
\text { for Africa }\end{array}$ & 19.56 & 14.46 & -5.1 \\
\hline Nigeria & 3.5 million & 4.24 million & +0.74 \\
\hline South Africa & 3.22 million & 3.13 million & -0.09 \\
\hline Kenya & 1.82 million & 1.59 million & -0.23 \\
\hline Zimbabwe & 1.44 million & 1.49 million & +0.05 \\
\hline Cote d'Ivoire & 1.03 million & 1.18 million & +0.15 \\
\hline Democratic Republic of Congo & 1.01 million & 1.01 million & 0 \\
\hline
\end{tabular}

Data only available for FY2013 and FY2014.

Source: U.S. Advisory Commission on Public Democracy (2014 and 2015);

Broadcasting Board of Governors (2015) 
Most American program objectives in African countries address democracy, governance, rule of law, youth engagement and education; spending was mostly found to be supporting mission initiatives, American Spaces and other cultural programs. ${ }^{141}$ Key programs included the Young African Leaders Initiative (YALI), ${ }^{142}$ Sahel \& Maghreb Coordination on Countering Violent Extremism \& Counterterrorism, al-Shabaab, Supreme Court Judges Visits, the African Women's Entrepreneurship Program (AWEP) and educational exchanges (p. 102 - 108). Challenges faced by the U.S. in Africa included "a rapidly evolving communication environment, weak partner institutions, difficult travel between the countries in Africa, tough work and living environments, and one-officer posts with limited experience” (p. 101).

Installation of the regional Africa Media Hub in Johannesburg, South Africa in 2012 was a direct effort to influence the African media by providing not only content but a direct conduit to U.S. officials and policy makers. The Hub has also trained African journalists. It is an example of " $21^{\text {st }}$ century statecraft" or "harnessing the networks and technologies of today's interconnected world to advance U.S. foreign policy” (Hammer, 2012).

\footnotetext{
${ }^{141}$ American Spaces are places for residents of other countries to learn about the U.S. They feature information on American policy, culture and values, English language classes, and information about studying in the U.S. The ten American Spaces with the highest funding do not include any African nations. However, American Spaces in South Africa, Zimbabwe, and Democratic Republic of Congo did receive "model" spaces created by the Smithsonian Institution.

${ }^{142}$ See U.S. Department of State (6/19/12, 7/20/12 and 10/30/14).
} 
Secretary Kerry, in a May 2014 post entitled "Africa is on the Rise, and We Need to Help Make Sure It Continues," contended that this was a "moment of decision" for African people and leaders. Would they pull out of violence and corruption and into their economic future, with the U.S. as a "friend" working to "develop the prosperity that is critical to a better future”? While Kerry promoted U.S. programs like Power Africa and the Young African Leaders Initiative (YALI), he said the transformation of Africa could only occur if Africans made "the right decisions."

A great deal of focus was put on the 2014 U.S.-Africa Leaders Summit in social media, not only to announce events but to draw lessons. Elizabeth Littlefield posted on September 5, 2014, that the summit would "redirect and, at long last, reframe America's engagement with Africa” as the agenda had not been entirely taken up with conflict, health, terrorism or humanitarianism. Rather, the summit had been suffused with the idea of Africa rising, a place "brimming with promise, with talent and with opportunity."

AGOA was promoted in 2015 in several posts. In one dated August 24, 2015, Dana Hyde, CEO of the Millennium Challenge Corporation and Michael Froman, U.S. Trade Representative, predicted that Africa would have "a more prominent role on the world stage” and was seeking economic partnerships that were "a good deal for Africa.” AGOA, they claimed, had "been tremendously effective" since its inception in 2000, and would continue to be so for another ten years. Further, they said the U.S. was building infrastructure through initiatives like Trade Africa, Power Africa and Feed the Future. Hyde and Froman recalled the 2014 U.S.-Africa Leaders Summit, and President Obama’s declaration that "the U.S. is not new to Africa... [but] engaged for decades, not as a colonial power, but as a partner.” This partner was not focused on resource extraction but economic 
growth. Just after this post, Linda Thomas-Greenfield, Assistant Secretary of State for African Affairs, also wrote about AGOA. It was key to "building an effective trading partnership between the United States and the countries of sub-Saharan Africa” and had encouraged diversification away from natural resources. She offered a local success story, and invited entrepreneurs and investors to find out more about American programs, trade hubs and "commercial diplomacy."

Interviewees had seen some success in public diplomacy efforts. Respondent A said the U.S. had been doing it "increasingly well," noting a focus on fighting the Ebola virus, and promoting elections and youth programs. Respondent B had seen a change since President Obama’s 2009 Ghana speech, noting that the Young African Leaders Initiative (YALI) and Global Entrepreneurship Initiatives had "attracted considerable attention.” Others saw success as mixed. Respondent C said there had been an effort in the early 2000s to appoint an envoy who would understand African issues. President Bush had also visited Africa several times during his administration. However, this respondent said, "nowadays there are less visits, less bilateral meetings (instead there is a forum with several African presidents) and less declarations on Africa's current affairs." Respondent D also saw mixed results. "The integration of the USIA into the State Department [in 1999] provoked a substantial disruption to many public diplomacy programs and activities, with some effects felt to the present. This has been countered somewhat by generally better direct communication with African leaders by increased senior-level U.S. visits to the region and other direct contacts, and growing sophistication within the U.S. government and specifically the State Department regarding use of both traditional and new (e.g. social media) public diplomacy tools.” 


\section{U.S.-Africa Policy Changes}

Policy changes are one way to track the importance of a global region, and there was a marked increase in attention paid to Africa beginning in 2011. However, even before this new period of focused American attention, the 2010 National Security Strategy noted that the U.S. was interested in "expanding the circle of nations - particularly in Africa who are capable of reaping the benefits of the global economy” by addressing the "provision of global public goods” (White House, p. 34). The Strategy also noted that, as Africa continued progressing toward strengthening its governance and democratic institutions, the U.S. would “embrace effective partnerships.” The focus was laid squarely on improvement of traditional American necessities, like rule of law, an end to corruption, and diplomatic resolution of crises. The U.S. promised to "work to remain an attractive and influential partner” by working on infrastructure development, the power grid, trade and investment (p. 45).

Then, in June 2012, President Obama released the U.S. Strategy Toward SubSaharan Africa, a policy directive meant to demonstrate the upgrading of Africa in U.S. foreign policy. The "four pillars" of U.S.-Africa policy outlined in this document are: (1) strengthening democratic institutions by promoting good governance and human rights, (2) spurring economic growth, trade and investment by promoting reforms, building on current U.S. programs, improving governance, promoting regional integration, expanding African integration in the global market, especially through renewal of AGOA, and improvement of supply-side constraints, encouraging U.S. companies to trade with and invest in Africa through the "Doing Business in Africa Campaign," (3) advancing peace and security through counterterrorism, regional security reform, preventing conflict and promoting 
peace, and (4) promoting opportunity and development, especially through the Global Health Initiative, Feed the Future, and the Global Climate Change Initiative (White House, 2012, p 2-7). Secretary Clinton was sent on a six-country African tour to promote the new strategy. Alex Vines, of the think tank Chatham House, said he had seen a "significant push" over 2012 by the Obama administration to "ensure that companies are more aggressive looking for market access and share” in Africa. This was "a delayed response to what China's been doing," he concluded (Look, 7/31/12). Secretary Clinton's trip “reflected Africa's growing strategic importance to the United States - not only with regards to security and counterterrorism but also energy” (Look, 8/10/12).

Other policy changes in this period included the First Lady's Young African Women Leaders Forum (2011), the Open Government Partnership (2011), the peacekeeping operations MONUSCO, UNMISS and ANISOM, the Partnership for Growth (PFG) (two of the four countries selected were in Africa) (2011), a new trade partnership with the East African Community (EAC) (2011), African Competitiveness and Trade Expansion (ACTE) (2011), leading the G-8 in launching the New Alliance for Food Security and Nutrition (2012), the Global Climate Change Initiative (GCCI) (2012), Trade Africa (2013), Power Africa (2013), Yes Youth Can campaign in Kenya (2013), funding for Tanzanian civil society (2013), the Africa Regional Anti-Corruption Training Program in West Africa (2013), Justice as a Right in Southern Africa (JARSA) Program (2013), support for Nigeria's Freedom of Information Act (2013), chairing of the Contact Group on Piracy off the Coast of Somalia (2013), creation of the President's Advisory Council on Doing Business in Africa (2014), the 20x20 Initiative on trade missions (2014), expansion of the U.S.-Africa Clean Energy Finance Initiative (U.S.-ACEF) (2014), the USAID-run 
Africa Private Capital Group (2014), Benchmarking the Business of Agriculture (2014), Tomorrow's Transportation Leaders Initiative (2014), the Clean Energy Solutions Center (2014), the Global Resilience Partnership between USAID and the Rockefeller Foundation (2014), the National Strategy for Combating Wildlife Trafficking (2014), and the announcement of over \$1 billion in committed funding for global entrepreneurship (2015).

In what might be seen as recognition of the status challenge China has posed to the U.S. in Africa, The National Security Strategy of 2015 mentioned China and Africa in the same breath, in President Obama's foreword. "The scope of our cooperation with China is unprecedented, even as we remain alert to China's military modernization and reject any role for intimidation in resolving territorial disputes," it read. "We are deepening our investment in Africa, accelerating access to energy, health, and food security in a rapidly rising region” (White House, p. 3). In a section titled "Shape the Global Economic Order,” the Strategy noted U.S. achievements under AGOA, as well as Feed the Future, Power Africa, Trade Africa and the Open Government Partnership (p. 16).

Another section, titled "Invest in Africa's Future” stated that “Africa is rising," not only through improvement in local economies but through greater support for democracy, human rights and rule of law. "For decades, American engagement with Africa was defined by aid to help Africans reduce insecurity, famine, and disease," the Strategy said. "In contrast, the partnerships we are forging today, and will expand in the coming years, aim to build upon the aspirations of Africans” (p. 26-27). 
President Obama's 2013 Trip to Africa

President Obama traveled to Senegal, South Africa and Tanzania in June/July, 2013. During the trip he held bilateral meetings with African leaders, attended meetings on rule of law, civil society, food security, participated in a town hall meeting for young African leaders and in a CEO roundtable and business leaders' forum. Obama wrapped up the trip with a visit to the Ubungo Power Plant in Tanzania (White House, 2013). Voice of America contrasted the goals of this trip (to discuss economic growth) with the previous stopover in Ghana in 2009 (democracy) (Powell, A., 2013).

During the trip, several threads became apparent. One focused on Africa as a “center of global growth” with a rising middle class which might want to buy American products. The other focused on Africa as a still desperately poor continent with massive problems in health, corruption, poverty and more. ${ }^{143}$

Press Secretary Jay Carney was asked at a certain point during the trip what U.S. businesses needed to see to "get in the game in Africa." Carney replied that overengagement in the Middle East had pulled the U.S. away from not only Africa, but Asia. The Africa trip was partly about intensifying the relationship with Africa, and showcasing America's “added value” in improving quality of life and encouraging democracy.

The reporter persisted, asking whether this American engagement was too little too late, especially given China's activities on the continent. Carney defended Obama's involvement throughout his term, citing Vice-President Biden's recent trip to Africa along

\footnotetext{
${ }^{143}$ See Randle (2013).
} 
with other prominent meetings. Carney concluded by saying "there is great merit in engaging... in Africa and we don’t have time to lose” (Carney, 6/26/13).

The trip seemed laced with understanding that Africa was slipping away. Deputy National Security Adviser Ben Rhodes noted during the lead up to the trip that "the U.S. would be ceding its leadership position in the world if the president of the United States was not deeply engaged in Africa. And that is what he is going to do” (Robinson, 2013). Voice of America reported that Obama had arrived with the intent of developing U.S. private investment in Africa, as the U.S. had fallen behind China. Further, the trip came just four months after Chinese President Xi Jinping visited Africa, just after his election (Joselow, 2013).

Jendayi Frazer, former Assistant Secretary of State for African Affairs, said about Obama’s trip that many Africans are concerned “that he hasn’t been more engaged, that he hasn't had more dialogue with them, and that his administration has not had greater influence, particularly when they compare that to the significant engagement that they are finding coming out of China” (Robinson, 2013). Mwangi Kimenyi of the Brookings Institution (2013) concluded that Obama’s criticisms of China during this trip meant "that he seems to have realized the extent to which American engagement has been overshadowed by new partners.” The message Obama appeared to be driving home was that the U.S. was ready to salvage its influence in Africa, even if that meant signaling “a new cold war.”

There were African protests against President Obama and the U.S. during the trip. The Congress of South African Trade Unions (COSATU) supported a "NObama Campaign” in protest of the American War on Terror and other military activities and 
strings-attached aid, seen as "neo-colonialist paternalism.” China, by contrast, was often seen as repressive only in its own domestic sphere; its non-interference policy was generally welcomed by African leaders (Anthony, 2013).

\section{U.S.-Africa Leaders Summit}

In August 2014, the U.S. hosted a first-of-its-kind three-day summit (themed "Investing in the Next Generation”) between the U.S. and most African countries in Washington, D.C. ${ }^{144}$ Its official purpose was to show “America's commitment to Africa’s security, its democratic development, and its people” while also demonstrating the “depth and breadth of the United States’ commitment to the African continent” (White House, U.S.-Africa Leader Summit, 2014). Six signature events ${ }^{145}$ were held alongside high-level leader discussions, which were focused on investing in Africa, peace and regional stability, governance, transnational threats and illicit financial flows. President Obama decided not to meet individually with each leader, as China had done at its FOCAC meetings, which was met with some criticism. The annual AGOA Forum was held in conjunction with the summit, as was the first U.S.-Africa Business Forum. ${ }^{146}$ First Lady

\footnotetext{
${ }^{144}$ Fifty African leaders plus the Chairperson of the African Union Commission were invited. The following states were not considered in good standing with the U.S. and African Union and were not invited: Central African Republic, Eritrea, Sahrawi Arab Democratic Republic (Western Sahara), Sudan, and Zimbabwe. Several leaders declined the invitation: the presidents of Algeria and Zambia for health reasons, the presidents of Liberia and Sierra Leone because of Ebola, the presidents of Angola, Botswana, and Egypt and the king of Morocco.

${ }^{145}$ These included "Faith Works: Honoring the Contributions of the Faith Community to Peace and Prosperity in Africa," "Civil Society Forum," "Investing in Women, Peace, and Prosperity," "Investing in Health: Investing in Africa's Future," "Resilience and Food Security in a Changing Climate," "Combating Wildlife Trafficking.”

${ }^{146}$ See more at http://usafricabusinessforum.bloomberg.org/\#/videos.
} 
Michelle Obama and former First Lady Laura Bush and the Bush Institute held a spousal program on education, health and public-private partnerships. The Congressional Black Caucus Africa Task Force hosted “A Dialogue with African CEOs.”

A number of side events hosted by both nonprofits and private companies took place in Washington during the summit. Finally, the Young African Leaders Initiative (YALI) program, which had been in place since 2010, was heavily promoted (White House, U.S.-Africa Leaders Summit, 2014). The U.S. unveiled more than $\$ 14$ billion in deals with Africa on clean energy, aviation, banking and construction, which was meant for African states working on improving the strength of their rule of law and reducing corruption (Ilunga, 2015). The Economist (2014) called the summit a mix of “idealism and commerce" whose support in Washington rested on a "curious coalition" of conservative Congresspeople, Christian groups, leftist Democrats and pro-business moderates.

In an early mention of the summit at the U.S.-African Union High-Level Dialogue in Ethiopia, Secretary Kerry took pains to ensure that leaders understood that the U.S. was inviting, not summoning, them. “It's really representative of the President's desire to make clear to the world, as well as to Africa, that we want Washington to focus more on this,” he said. "And we believe that by inviting people to come to Washington, it will help the Congress of the United States. It will help the American people. It will help everybody to be able to share in the importance of this agenda” (Kerry, 5/1/14). Former U.S. Ambassador to Nigeria and current senior fellow at the Council on Foreign Relations, John Campbell, believed one reason for the summit was to "raise Africa’s profile within the U.S.... to make American companies aware of opportunities” (Huck, 2014). 
Just before the summit, Assistant Secretary of State for African Affairs Linda Thomas-Greenfield explained the two main objectives of the event to the Atlantic Council. First, Africans should gain an understanding of American fondness for Africa and its and desire for partnership. Second, American companies were being asked to elevate their investment in Africa and create new linkages between American and African businesspeople. Pains were taken to distinguish the summit as a move away from business as usual, toward something more "interactive and conversational." The agenda was said to have been formed from input by African leaders, ambassadors, private sector participants, agencies and civil society, although the topic of "development” was clearly missing from the summit (Cylke, 2014).

Secretary Kerry, speaking in December, 2014 at a Corporate Council on Africa event, said: "Every Head of State I've spoken to since the [U.S.-Africa Leaders] Summit told me how pleased they were. They left with the sense that Americans, particularly American businesses, were serious about engagement and serious about operating in partnership. This was our highest priority for the Summit and, thanks to you all, we succeeded... With the summit, we had the opportunity to celebrate our relationship with African nations and showcase our partnerships. The summit was not about starting a "new" era in U.S.-Africa relations, but rather a reflection of great strides we have already made” (Kerry, 12/16/14).

Ben Rhodes, National Security Advisor for Strategic Communications, assured reporters in a 2014 on-the-record conference call that the summit was "an historic opportunity” to show Africa “America’s commitment to investing in Africa’s development and future peace, prosperity and security.” Not only was the summit the most sizable 
assemblage of African leaders to ever meet with a U.S. president, it was a "a very clear signal that we are elevating our engagement with Africa.” Rhodes admitted that in the planning stages the U.S. had been aware that "other nations hold summits with African leaders” but the focus had been on bringing out distinctive U.S. qualities and opportunities. This American uniqueness centered on "our focus on African capacity-building and integrating Africa into the global economy and security order." While not a "culmination," the Summit was expected to be a "game-changer" and a "big step in the long evolution of our Africa policy” focused on "tangible outcomes.”

Rhodes, in response to a question on how the U.S. can prove it is different from other countries engaging in the continent, said that President Obama has claimed that other countries are welcome in Africa and may provide valuable assistance and infrastructure. Rhodes said:

We are less focused on resources from Africa and more focused on deepening trade and investment relationships. And I think the way in which that will be demonstrated at the summit is if you look at the nature of our engagement -- first of all, we are engaged across the U.S. government so that it is not simply the State Department, but the Commerce Department, the United States Trade Representative, OPEC and Ex-Im -- all have very deep ties in Africa. All of those principals have made recent trips to Africa or had recent meetings with African leaders to discuss what the United States can do to increase our trade and investment footprint on the continent (Rhodes, 8/1/14). 
Assistant Secretary Thomas-Greenfield stressed the continuing importance of bilateral relationships, and dismissed the idea that the summit was "a reaction to some other event or some other country's activities in Africa.... We are not threatened by the presence of other nations in Africa. Rather, we encourage our African partners to determine what relationships, whether transactional or enduring, will most benefit the lives of their people” (Thomas-Greenfield, 7/31/14). The strenuous denials seen here from American officials seemed designed to put reporters off the idea that the U.S. was in any way attempting to copy China or follow in its footsteps. This does not, however, mean that the U.S. was not doing exactly that.

Melvin Foote of the Constituency for Africa said that the summit was clearly a response to China. "The administration won't tell you that but it's at the front of their mind. America is losing influence and respect in Africa," he said. "I hear it whenever I travel there." He added that refusing to meet one-on-one with African leaders was an error. "Even if it were 10 minutes in duration to shake Obama's hand and lay out your priorities. Even to just get a picture with the president in the Oval office and show the picture back home. A lot of African countries are very upset about this” (McGreal, 2014).

Ambassador David Shinn (2014) claimed that the U.S. may have been reflexively reacting to European, Japanese or Chinese summits in Africa, but also important was the American realization that it "has paid insufficient attention to the [African] continent at the highest levels of government in recent years." Emmanuel Nnadozie of the African Capacity Building Foundation in Zimbabwe said that "although the U.S. has been slow to react [to other countries' activities in Africa], hosting the summit was a sign that it can no longer stay on the sidelines (Nijraini, 2014). John Nijraini of Africa Renewal (2014) believed that 
African leaders had a new sense of confidence, brought on by attention showered by countries like China, which they showed at the summit. The President of Kenya, Uhuru Kenyatta, said at the time "it is good to see the U.S. is waking up to the realities of the potentials of Africa just as China did a long time ago.”

Ambassador David Shinn (2014) believed increasing U.S. interest was due to an improved U.S. domestic economy, new opportunities in Africa and the spread of terrorism in Africa. He cautioned there was no guarantee that the U.S.-Africa Leaders Summit would occur again in the future. Christopher Wood of the South African Institute of International Affairs said: "The U.S. was under competitive pressure from the more formalized relationships that China and the European Union have with Africa. The summit reflects some recognition of the improved growth potential of the continent, and the need to get in early in the Africa rising story” (Sputnik, 2014).

Interviewees saw a range of reasons why the summit was held. Respondent A said it was meant "to highlight the U.S. relationship with Africa and increase awareness of the opportunities.” Respondent B said the purpose was to highlight the importance of U.S.Africa relations, and to discuss trade, investment, democracy, peace and security, and development. Respondent C said, "It became important for the U.S. to show increased interest towards Africa especially with the Africa rising narrative.” Further, Respondent C saw the goals as being to bring together stakeholders to discuss investment opportunities in Africa. Respondent D said the goal was, “To reinforce personal, official, and institutional ties to Africa and to publicly (in the U.S. and in Africa) reinforce a sense of U.S. interest and opportunity." These responses show that these officials believed the summit was meant to be both designed to raise awareness domestically and to demonstrate interest in Africa 
in the face of others' interest there. As such, the summit appears to have been perceived as having a component of public diplomacy, meant to convince foreign publics (which might include African and Chinese leaders and African citizens) that the U.S. had not forsaken Africa.

Of the two respondents involved in planning the summit, Respondent A said there was discussion about how it would be different. Respondent B said that "we noted that China - like France, Japan, Turkey and others - hosted summits with Africa.” However, respondents were staunchly opposed to the idea that the summit was modeled on Chinese FOCAC summits. Respondent B said it simply was not. Respondent C said, "the U.S. also has a history of bringing together stakeholders in such fora." Respondent D said, "While I suppose those involved in planning were certainly aware of past Chinese summits and high- level contacts, the specifics of the U.S. and how it operates both politically and economically would mean the overall structure of the summit would by necessity need to be different." Further, Respondent D said, "I would like to believe that the U.S. approach was driven by a recognition that speeches or anything suggesting unilateral approaches, as opposed to "conversation" or true consultation and dialogue, is not generally effective in Africa. The U.S. experience with the AFRICOM rollout should have been an instructive lesson, for example, in that regard as well as other past experiences.” As discussed in the Next Steps section of Chapter Eight, it may be that the U.S. imitated FOCAC summits just enough to be perceived as in the same category, while differentiating itself through a more consultative type of meeting. It is interesting that none of the respondents believed the U.S. modeled its summit on Chinese FOCAC summits. It is possible that simple awareness of 
FOCAC was sufficient to drive the American summit, which could not help but be its own, typically American, type of event.

All the respondents felt the goals and objectives had been met. Respondent A called it “an incredible week.” Respondent B said that, as the president's concluding comments showed, all of the subjects on the agenda had been discussed. Respondent $C$ felt they had been met to a degree since there were business pledges made by companies. Respondent D said:

While these kinds of objectives are obviously difficult to quantify, I believe they were achieved. The mere fact of the summit, the level of attendance, and involvement of the president and key senior officials, as well as other leaders all but ensured reinforcement of personal and institutional ties. While public/media attention could have been better, at least in the U.S., at least some increased attention and focus was given to this generally underreported region. In Africa, I would find it difficult to assess the success of public and media coverage throughout the continent, but from my experience must assume that the summit received a relatively widespread and favorable coverage. My experience also suggests that African leaders generally respond well to specific demonstrations of senior-level U.S. interest and involvement, such as the summit.

The respondents pointed to the lack of certainty that often surrounds public diplomacy efforts. Some pointed to the lack of media coverage of the summit and surrounding events, which will be touched on later in this chapter. The media's lackluster coverage was likely the result of low domestic concern for Africa. Respondent D’s vision 
of success included the attention given by high-level American officials, which lent weight to the event and brought a fuller sense of American power to African (and Chinese) eyes. Interviewees believed the summit was successful overall. Respondent B felt there was "very effective delivery by the President.” Respondent D, although not directly involved in summit planning, had the impression that it was "generally effective in conveying a sense of U.S. interest in dialogue versus unilateral approaches, and thus almost certainly more effective in conveying messages been many passed U.S. initiatives.”

\section{President Obama's 2015 Trip}

President Obama visited Kenya and Ethiopia in July 2015. The major event of this trip was the Global Entrepreneurship Summit, held in Nairobi, Kenya, where Obama announced over \$1 billion in funding for entrepreneurs. He also held bilateral meetings with African leaders, including the controversial President Kenyatta of Kenya, ${ }^{147}$ visited a food production facility and a new Boeing Dreamliner bought by Ethiopia, and introduced executives like Steve Case of AOL to the continent. The decision to visit controversial states like Kenya and Ethiopia, which no U.S. president had done, seemed related to Chinese activities there. ${ }^{148}$ However, the Ethiopia leg may have simply been related to Obama's July $28^{\text {th }}$ speech at African Union headquarters. The media generally cast both the 2013 and 2015 trips as responses to China’s activities in Africa. Peter Kagwanja (2015) wrote that the Global Entrepreneurship Summit in fact "revealed that America has fewer

\footnotetext{
147 See http://www.bbc.com/news/world-africa-21544245 for a profile.

148 See AllAfrica.Com (2014), Shinn (2014), Aljazeera (2014), Baker \& Santora (2015), Naidoo (2015), Tiezzi (2015), and Federal Democratic Republic of Ethiopia (2015).
} 
opportunities to offer African countries than China” and that the U.S. had become an "underdog in the battle for the hearts, minds and souls of Africa, [trailing] behind China on almost every count.” 149

Chinese media reacted strongly to this trip, essentially accusing the U.S. of attempting to counteract Beijing's influence in Africa. Liu Zhun (2015) noted that despite Obama's comments about welcoming Chinese activities in Africa, "his diplomatic rhetoric can't conceal the notion that the U.S. is nervous about its rise, taking China as a rival in Africa.” The U.S. "obviously lacks a consistent Africa policy," he continued, calling the precipitous drop in U.S.-Africa trade something that "has touched the nerves of the U.S." He blamed "the remnants of colonialism" for the perception that China is not "another constructive power bringing welfare to [Africa]." He concluded by saying "Let’s hope Washington plays its cards fair and square, and does not make the land an arena for majorpower rivalry.” Xinhua News (2015) reported that U.S. aid projects and initiatives, such as Power Africa, were "lackluster” and that, despite massive infusions of aid, a gap between promises and results persisted. It also accused President Obama of "playing the family card” (his Kenyan heritage) and "paying lip service to Africa.” Xinhua accused the U.S. of "paternalistic intervention" and of "forcing its so-called democratic values" onto Africa, contributing to Africa's internal conflicts.

${ }^{149}$ See Voice of America (6/25/13 and 6/30/13), Joselow (2013) and Kagwanja (2015). 


\section{Taking A Stance: U.S. Versus Chinese Values}

During this period, the U.S. seemed to position itself as opposed to the values of China in Africa, sometimes obliquely, and sometimes directly. Several themes became clear. One of these was the idea of the U.S. adding value rather than extracting it, a dig at the perceived perniciousness of China's Africa tactics. ${ }^{150}$ An example of this occurred during remarks by Secretary Clinton at a meeting of U.S. and South African business leaders in Pretoria, South Africa in 2012. “The United States... is working to build partnerships that add value rather than extract it,” she said. She then proceeded to list all the ways the U.S. would be a good partner, such as by helping install renewable energy generators, improving "economic statecraft," supporting small businesses, providing funding through the Overseas Private Investment Corporation, and more, all while not mentioning China by name (Clinton, 8/7/12).

Another was the idea of Africa holding its partners to a higher standard, which the U.S. and Europe already felt comfortable meeting. ${ }^{151}$ An example of this occurred when Assistant Secretary Carson testified before the Senate Subcommittee on African Affairs in 2012. He said: "We tell our African colleagues that they should hold China and Chinese companies to the same rigorous high standards that they hold American, European, and other Asian countries, including Japan and South Korea, to when they enter into trade agreements” (Economic Statecraft, 2012). While claiming to recognize China’s right to be an economic competitor in Africa, the U.S. also implied it was not responsible or open.

\footnotetext{
150 See also Look (8/1/12).

${ }^{151}$ See also French (2014, p. 75-76).
} 
Assistant Secretary Carson, in the same Senate hearing, said: "To our African partners we say look at what you get. Look at it transparently and openly, and we hope that you will accept what is, in fact, best for you. To the Chinese, we say to them that it is important to carry out your activities in an open and transparent way and one in which you are treating Africans as partners in the process."

A third involved the American faith in the superiority of democracy, which would as a matter of course lead to better outcomes for Africans, and a strengthened ability to protest the injustices China might foist upon Africa. An example of this can be seen in Assistant Secretary Carson's February 2010 on-the-record briefing about a recent trip to Africa. When asked about China's activities in Africa, Carson said Africans must: ... manage very skillfully and carefully their relationship with China on the economic and commercial side... this is an issue where it's important to be able to have democratic institutions so that the voices of people at the bottom who are engaged and involved in [projects] can speak effectively about the consequences to their leaders (Carson, 2/24/10).

Finally, the U.S. sometimes mentioned simply the spread of "a new colonialism," without naming any specific countries, but with the strong implication that indeed China was the target. In June 2011, Secretary Clinton, while visiting Zambia said:

When people come to Africa and make investments, we want them to do well, but we also want them to do good. We don't want them to undermine good governance. We don't want them to basically deal with just the top elites and, frankly, too often pay for their concessions or their opportunities to invest. 
China's non-interference policy appeared to be particularly galling for the U.S. An example of this occurred in a 2013 U.N. General Assembly speech, where President Obama said:

... sovereignty cannot be a shield for tyrants to commit wanton murder or an excuse for the international community to turn a blind eye... Ultimately, that is the international community that America seeks - one where nations do not covet the land or resources of other nations, but one in which we carry out the founding purposes of this institution and where we all take responsibility...

In 2015, President Obama spoke at the African Union headquarters in Addis Ababa, Ethiopia. The speech was designed to showcase American values and goals - including democracy, rooting out corruption, improving health issues, and dealing with terrorism but also apparently to dig at China. Obama claimed to have "called on the world to change its approach to Africa” after having been told by Africans “we don’t want just aid, we want trade that fuels progress. We don't want patrons, we want partners who help us build our own capacity to grow." Obama asserted that he had worked as president to "transform America’s relationship with Africa.” He acknowledged that "many of your nations have made important reforms to attract investment” and that the U.S. wasn't alone in seeing African potential. He continued:

When more countries invest responsibly in Africa, it creates more jobs and prosperity for us all. So I want to encourage everybody to do business with Africa, and African countries should want to do business with every country. But economic relationships can’t simply be about building 
countries' infrastructure with foreign labor or extracting Africa's natural resources. Real economic partnerships have to be a good deal for Africa -- they have to create jobs and capacity for Africans.” On democracy and the American willingness to speak out against repression, Obama said “And I know that there’s some countries that don’t say anything - and maybe that's easier for leaders to deal with. But you're kind of stuck with us - this is how we are. We believe in these things and we're going to keep talking about them (Obama, 7/28/15).

Melissa Cook, founder and managing director of African Sunrise Partners and a member of the President's Advisory Council on Doing Business in Africa, said about Obama's speech: "Obama was in the unique position to come here and say things to the Kenyans that may not have been as effective had they come from someone else. He made some very direct statements about supporting democracy and supporting human rights... The Chinese do not come here and talk about those things" (Davies, 2015). The U.S. does not appear to be backing away from its commitment to certain values, and in fact, may be using them to demonstrate competitive advantages compared to China, as seen in the next section.

\section{The U.S. Advertises Itself as A Better Partner Than China}

This section will explore the idea that the U.S. began to present itself as a better partner for Africa than China would be. This is distinct from simply presenting the U.S. as a good partner, in and of itself, although this is a component. 
In early attempts to better position itself in Africa, it was clear the U.S. continued to have a certain mindset which focused on humanitarian issues and not on Africa's economic growth potential. In 2008, National Security Advisor Stephen Hadley, when asked if he thought China was acting irresponsibly in Africa, replied that Africa was not simply an economic opportunity but a global "public responsibility." Transformation in Africa would depend on investment in health, education and trade. Later, the U.S. appeared concerned that its aid, though massive, was invisible next to Chinese infrastructure projects. ${ }^{152}$

The U.S. promoted itself as transferring technology, using local labor and being transparent in its dealings, as it operated under the Foreign Corrupt Practices Act, as well as labor and environmental standards. ${ }^{153}$ Additionally, working with the U.S., some claimed, raised the status and reputation of African states. ${ }^{154}$

But President Obama took a new tack by laying bare an economic motivation to be in the continent. When questioned at a Town Hall with young African leaders in 2010 about whether a true partnership could exist between a strong country (the U.S.) and weaker African ones, Obama replied:

All countries look out for their interests... the interests of the United States and the interests of the continent of Africa greatly overlap. We have a huge interest in seeing development throughout Africa -- because we are a more mature economy, Africa is a young and growing economy, and if you can

\footnotetext{
${ }^{152}$ See Clinton (1/6/10).

${ }^{153}$ See Economic Statecraft (2012, Carson, p. 26-27), Randle (2013) and The Economist (2014).

${ }^{154}$ See Is There an African Resource Curse? (2013, Alicante, p. 56).
} 
buy more products... that creates jobs here in the United States of America.... Your success will enhance our position rather than reduce it (Obama, 8/23/10).

In 2011, Assistant Secretary Carson made it clear that he believed the U.S. was competing for Africa, and that loss of economic share might lead to loss of political influence. "Helping African countries, no matter how small and poor, realize their full potential and succeed as economically viable democracies is in our national interest," he said. "If fledgling democracies are allowed to fail and undemocratic regimes are allowed to endure unchallenged, then people will lose confidence in democracy and free market economic principles, and we will find ourselves on the defensive in the global competition for influence and ideas” (FY2012 Budget).

The U.S. was reluctant to let go of its focus on democracy and human rights. In 2012, Secretary Clinton, on a trip to Africa intended to drum up business opportunities, attended the U.S.-South Africa Business Summit in Senegal. There Clinton said: "the United States will stand up for democracy and human rights even when it might be easier or more profitable to look the other way, to keep the resources flowing. Not every partner makes that choice, but we do and we will.” China retaliated against these comments, calling them "cheap shots” with the goal of “discrediting China’s engagement with the continent” (Look, 8/5/12).

The U.S. seemed determined to treat African leaders as responsible adults, not infantilized children, and seemed concerned about appearing paternalistic or dogmatic. ${ }^{155}$

\footnotetext{
${ }^{155}$ See Hadley (2/13/08), and also Carson (7/30/09) and his hope that the U.S. was not lecturing Africa, and that "other countries" should do the right thing in looking at issues like child soldiers and governance. See also Obama (8/23/10) and French (2014) who claimed that "behind the fraternal masks, Chinese officials
} 
Leaders often urged Africans to be careful with natural resources, ensuring their use was advancing development, diminishing poverty, and avoiding a new kind of colonialism. ${ }^{156}$ In 2013, during remarks with President Zuma of South Africa, President Obama offered a list of questions Africans should ask of any country offering a deal:

If somebody says they want to come build something here, are they hiring African workers? If somebody says they want to help you develop your natural resources, how much of the money is staying in Africa? If they say they're very interested in a certain industry, is the manufacturing and value added done in Africa? Are they tolerating corruption that's not benefiting the people but just benefiting a few at the top in their interactions with African countries?

He then offered to partner with anyone willing to assist Africa, as long as they were really helping Africans. At a Town Hall meeting during President Obama’s 2013 trip, the president reiterated his cautions to Africans that the actions of other countries must benefit Africans. "I want to make sure whoever you're dealing with that you're getting a good deal benefiting people here, to help spur on broad-based development. Hopefully that's the kind of relationship you'll be able to have with the U.S.” (Obama, 6/29/13). Obama, in a July 2013 article based on a speech published in The Star, South Africa, newspaper, told Africans "the world will be watching what decisions you make" as "governments and businesses from around the world are sizing up the continent, and making decisions about

\footnotetext{
thought of [Africans] as children, capable only of baby steps, to be brought along with sugary inducements and infantilizing speech” (p. 221).

${ }^{156}$ See Hadley (2/13/08), Clinton (8/6/09 and 8/10/09), Obama (6/29/13, Zuma) and The Economist (2014).
} 
where to invest their own time and energy.” Obama connected the peace, freedom and prosperity experienced in Africa with that experienced in the U.S. He then promised to "bring together business leaders from America and Africa... launch new trade missions, and promote investment from companies back home... renew AGOA and launch the Trade Africa initiative...” But the U.S., unlike some other countries, would look beyond "numbers on a balance sheet or the resources that can be taken out of the ground" to freedom, health, hunger alleviation, and provision of electricity. If Africa's leaders could "exist to serve their people," then America would be free to partner with Africa to create growth for society and for individuals. It was not "meddling” to seek this freedom. "Africa must lead and America will help... as you guide Africa down that long and difficult road, I want you to know that you will always find the extended hand of a friend in the United States of America," he concluded.

In 2014, while promoting the "summer of Africa" in Washington, D.C., including the Young African Leaders Washington Fellowship program and the U.S.-Africa Leaders Summit, Assistant Secretary of State for African Affairs Linda Thomas-Greenfield was asked whether the U.S. was disturbed by China’s relationships with African countries. "We aren't concerned," she responded. "We know that China has an interest in the region. The Chinese premier was in Africa shortly after our visit to the continent. And what we say to the people of Africa is that they have to ensure that as they negotiate with the Government of China, that they get the best deal possible for the people of their country... So we do want Africans to benefit from the largesse that China may be able to provide for them, and we want to work with the Chinese to ensure that what they are providing helps to pursue a prosperous Africa for all of its people in the future” (Thomas-Greenfield, 5/14/14). 
President Obama, speaking with The Economist in 2014 just before the U.S.-Africa Leaders Summit, said that, even in the midst of "greater competition" in Africa, the U.S. could "still be central to the process of moving Africa into the next stage of growth.” This was premised on "America's strengths," which included "the global standing of its companies to its traditions of transparency, accountability, the rule of law and property rights... [and] ideas and innovation.” He concluded that “America is better than just about anybody else at smart applications of technology." China, on the other hand, might have “deep pockets" but its "need for natural resources may color its investments, in ways that are less true for Americans.”

Ben Rhodes, Deputy National Security Advisor, said at a news conference in 2015, just after Obama's trip, that China has "played a constructive role" in Africa in areas such as infrastructure. As for the United States' relationship with Africa, he said, "We're not just in it for a set of natural resources; we're here to build African capacity. And that type of partnership over the long run I think does distinguish the United States. It's something that we bring uniquely to bear” (Rhodes, 7/26/15). In 2015, at the AGOA Forum meeting in Gabon, U.S. Trade Representative Michael Froman said the U.S. "is not new to Africa" having been involved "for decades, not as a colonial power, but as a partner - one focused not just on extracting resources from the continent, but investing in human resources” (Froman, 2015).

Peter Baker (2015) believed that President Obama spent his 2015 Africa trip "to suggest that the United States offers an alternative to China's aggressive courtship of the continent," by attempting to showcase the U.S. as providing “a better, more empowering vision for Africa’s future." He did this at every opportunity, cautioning Africans to "be 
wary of China's appetite for oil for its own use" and to join the U.S. in working on "economic growth, democracy, health care, education and electrification." Baker noted the environment where Obama delivered this message was steeped in Chinese influence, from the African Union headquarters (built by China in 2012 at a cost of $\$ 200$ million) where he delivered his main speech, to the Xinhua News jumbo screen outside, to the local roads, airports and railways China was or would be working on.

Interviewees were not convinced, however, that the U.S. was actively attempting to be seen as a better partner than China. Respondent D said, "I am not sure that the U.S. was seeking to present itself as a 'better' partner than China as such, as opposed to being a good and valuable partner. I do not see that Chinese and U.S. 'partnerships' in Africa are mutually exclusive, or represent a zero - sum exercise. Both can and should be valuable from an African perspective, and for the U.S. can in fact at times be mutually reinforcing. Commercial competition does not necessarily involve confrontation (e.g. U.S./Canada or U.S./Europe relations), although it can, and political goals and objectives can be complementary in some cases even while in conflict in others.”

Yet, this view appears to be contradicted by on-the-ground evidence, presented above, of the president and other high-level officials repeatedly referencing the U.S. as not only a good partner, but one that was better for Africans than others, specifically China. It is possible that high-level officials began to act differently than other American actors, as they attempted to navigate a course they had begun to see as rife with status competition. 


\section{The American Reaction as Status Competition}

It appears that the American reaction to Chinese activities was to attempt to win over the African public, as shown previously in this chapter. But why? In fact, it appears that not only did the U.S. have little to gain economically from Africa, but also that its domestic public has been and remains uninterested in the continent, as will be shown below. Removing these two factors leaves the possibility that in fact the reaction was not to Africa's real opportunities but to China's threatening dominance in the region. Was the U.S. afraid of losing Africa, or of losing Africa to China?

\section{The U.S. Had Little to Gain Despite “Africa Rising” Narrative}

Rick Rowden (2013) claimed that the “Africa Rising” narrative, which positioned select African countries as fast-growing economic superstars, was highly exaggerated and incorrect. Those that promulgated it were using "unhelpful indicators" to show African development, including GDP growth rates, per capita income, growth in mobile phones, mobile phone banking, tourism and retail, and increases in African trade and in the number of African billionaires. He contrasted this with what wealthy countries know well, which is that they must progress beyond "dead-end activities that only provide diminishing returns over time (primary agriculture and extractive activities such as mining, logging, and fisheries), and into activities that provide increasing returns over time (manufacturing and services).” Only this is true development. 
A key problem in the Africa Rising narrative has been not only that manufacturing is not happening on the continent, but that this issue is not even mentioned in the narrative. Comparing Africa to China is misleading because, while they both have large, young populations as a labor source, China industrialized and Africa has not. The United Nations (2011) found that the percentage of manufacturing value added (MVA) in exports fell in Africa's GDP from $12.8 \%$ in 2000 to $10.5 \%$ in 2008 , while in Asia it rose from $22 \%$ to 35\%. Africa's share of global MVA fell from a tiny 1.2\% in 2000 to $1.1 \%$ in 2008, while Asia's went from $13 \%$ to $25 \%$. These figures are shown below in Table 9. Africa's share of low-technology manufacturing activities in MVA fell from 23\% in 2000 to 20\% in 2008.

Table 9: Manufacturing Value Added in Exports, 2000 And 2008

\begin{tabular}{|c|c|c|c|c|}
\hline & $\begin{array}{c}\text { MVA in Exports } \\
\text { in GDP (2000) }\end{array}$ & $\begin{array}{c}\text { MVA in Exports } \\
\text { in GDP (2008) }\end{array}$ & $\begin{array}{c}\text { Share of } \\
\text { Global MVA } \\
\text { (2000) }\end{array}$ & $\begin{array}{c}\text { Share of } \\
\text { Global MVA } \\
\text { (2008) }\end{array}$ \\
\hline Africa & $12.8 \%$ & $10.5 \%$ & $1.2 \%$ & $1.1 \%$ \\
\hline China & $22 \%$ & $35 \%$ & $13 \%$ & $25 \%$ \\
\hline Difference & $9.2 \%$ & $24.5 \%$ & $11.8 \%$ & $23.9 \%$ \\
\hline
\end{tabular}

Source: United Nations (2011). 
Further, Africa's high dependence on natural resource extraction shows a lack of economic diversification and reveals production capabilities in an infantile state. The share of resource-based manufactures in Africa's total manufacturing exports was 52\% in 2000 and 49\% in 2008. The African Development Bank (2012) reported that "Africa's growth tends to be concentrated on a limited range of commodities and the extractive industries... These sectors are not generating the employment opportunities that would allow the majority of the population to share in the benefits. This is in marked contrast to the Asian experience, where the growth of labor-intensive manufacturing has helped lift millions of people out of poverty..." (p 2). Africa needed the ability to bring certain industrial policies to bear but wealthy industrialized countries often blocked them, put conditionalities on loans and agreements, and yet offered a "happy narrative” about Africa rising (Rowden, 2013).

In 2015, China's economic slowdown, volatile stock market and yuan currency devaluation had a ripple effect in Africa. The MSCI EFM Africa Index of shares fell 18\%, and African currencies have faltered against the dollar. Power shortages, especially in South Africa, and collapsing oil prices, especially in Nigeria, caused much of the problems. Angola, Ghana and Zambia suffered from low commodities prices. David Cowan, an Africa economist with Citigroup, Inc. called the idea that Africa was rising "an oversold story” (Cohen and Vollgraaff, 2015).

The International Monetary Fund's (IMF) World Economic Outlook (2015) forecasted 2015 economic growth for Africa was 3.75\%, the lowest in six years. Growth was predicted to rise slightly for 2016, to 4.25\%. Further, the IMF reported that, while it had appeared be benefitting economically, Africa had in fact been "stagnant or going 
backwards.” The World Bank predicted 2015 African growth would be 3.7\%. John Ashbourne of Capital Economics warned that " 2015 would be Africa's most difficult year so far this century” (Ndaba, 2015).

Countries reliant on oil exports, like Nigeria, the Republic of Congo and Angola, have had to deal with falling oil prices (\$49 per barrel in October 2015), and collapsing demand. Countries reliant on mineral exports, like South Africa, Ghana, Guinea and Zambia, have also been hit by lowered commodity prices. Countries that had diversified beyond oil and minerals, like Ethiopia, Kenya, and Senegal, should fare slightly better (BBC, 10/27/15). Lower fuel prices could have the benefit of increasing consumer purchasing power and spiking domestic demand (World Bank, Africa Overview, 2015).

The economic slowdown in China, commodity price falls and electricity shortages are not the only issues, the World Bank reported in Africa's Pulse (2015). Limited policy space, which might allow for monetary surpluses or a smaller debt burden, plus liquidity buffers, such as international reserves, have tightened the ways African countries can respond to economic issues (Copley, 2015).

\section{Lack of American Domestic Support for Africa}

The 2008 recession, combined with the reluctance of American businesses to operate in "parts of the world that do not treat their people properly, having the right governance and transparency" (Clotty, 2012), have led to a distinct lack of commercial interest in the U.S. This section will demonstrate lack of domestic support through the illustrative example of the U.S. Export-Import Bank, and describe how the American public has related to Africa. 


\section{Reauthorizing The U.S. Export-Import Bank}

The U.S. Export-Import Bank, which provides loans and assistance to companies wanting to export U.S. products overseas, was not reauthorized in June 2015 due to controversy over its duties. Some Republicans believed that the Bank was interfering in the free-market economy, and had become an example of government overreach (Davis, 2015). Others felt loans made by the Bank were in danger of default, especially in difficult global economic times (Wingfield, 2015). In September 2015, South African airline company Comair Ltd. informed Boeing it might have to withdraw from its $\$ 1.1$ billion order for new airplanes due to lack of financing from the Export-Import Bank. Ethiopian Airlines was similarly forced to delay an order due to lack of financing (Copley, 2015). Sub-Saharan Africa is considered a “priority region” for the Bank, providing \$2.05 billion in transactions in 2014 alone, and \$6.6 billion since 2009 (U.S. Export-Import Bank, 2016).

U.S. Chamber of Commerce president and CEO Thomas J. Donohue said in 2015 that failure to reauthorize "would amount to unilateral disarmament in the face of other countries’ far more aggressive government export credit programs” (U.S. Chamber of Commerce, 2015). In October 2015, the House of Representatives voted to reauthorize after it was attached to a highway bill. In December 2015, the House bill went to the Senate, which approved a similar reauthorization under a transportation bill (Calmes, 2015). The House and Senate reached an agreement to authorize authority through September 30, 2019 (Wingfield, 2015).

The lack of urgency apparent in reauthorizing the Bank, which is heavily involved in promoting business with Africa, points to a lack of concern for the opportunities there. 
It is difficult to imagine a similar situation with an institution involved in more mainstream trading areas.

\section{American Impressions of Africa}

Kirsten Morgensen (2015) asserted that “despite the lack of detailed information [citizens have] about other nations... they [still] create mental images" using "information shortcuts." This creates a "low-information rationality” (p. 319). According to Curtis Keim (2014), the general impression Americans have of Africa is that it is "a primitive place, full of trouble and wild animals, and in need of our help” (p. 5). America's historical dealings with Africa, which included slavery, missionaries and the condoning of European colonization, were exploitative and as such cast Africans as inferior (p. 7). Today, those who work with Africa, including bureaucrats, aid organizations and businesses, likely all "have an interest in describing Africa in ways that justify the importance of their own work"; that is, negatively (p. 9). Exoticism, filled in by stereotype, allows Americans to perpetuate myths about Africa, and to enhance Western self-definition (p. 10-11). The media generally portray Africa through stereotypes (such as television shows about wild animals) and through categories like "trouble in Africa" and "curiosities in Africa." News reporting (which can be a rare event for Africa) is often biased by Western aid groups or glosses over uncomfortable realities (p. 18-19).

According to Asgede Hagos (2000), it is the press which brings about public awareness of an issue, which then leads both the public, and then policy makers, to conceive of certain issues as more essential than others. The media's neglect of Africa, and its stereotypical assumption that the continent is a mass of tragedy and hopelessness, are 
reflected in a comment made by a Washington Post editor, that "the West ought to build a fence around Africa, peek over it now and then, and after 100 years, tear it down to see what's left" (p. 3 \& 133).

The Africa rising narrative, which took hold in the mid-2000s, does not appear to have overcome the persistent stereotypes Americans hold toward Africa. Now, as Africa appears to be collapsing, American attention continues to be held mainly by crises and humanitarian needs. While Americans appear to be unconvinced that Africa is indeed a rising economic landscape, they are certainly concerned about China, as shown in Figure 7 below.

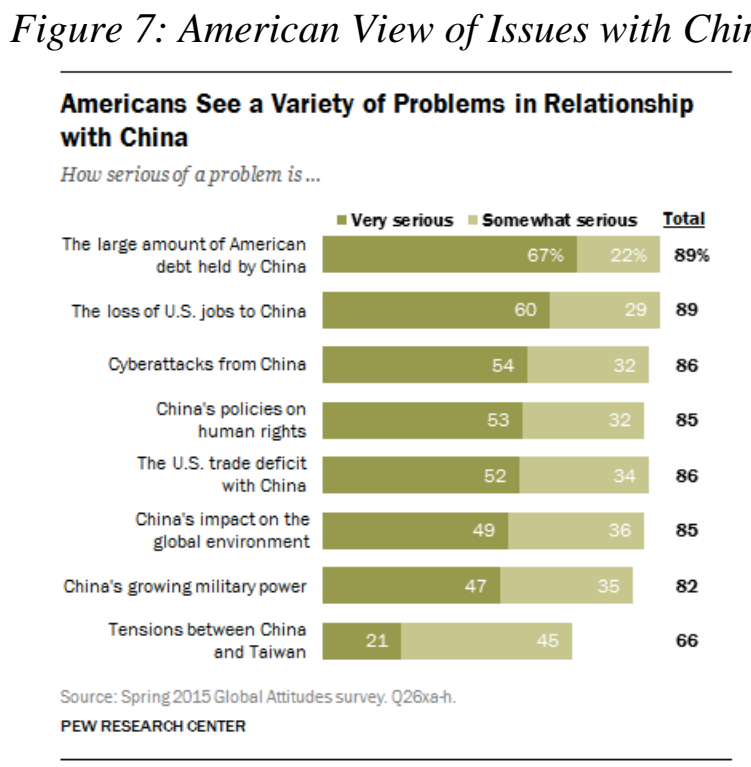

Source: Wike, R. (2015).

It has been shown that American presidents generally follow domestic public opinion in foreign policy. ${ }^{157}$ If this is the case, it strengthens the idea that the U.S. has only

\footnotetext{
${ }^{157}$ See Burstein (2003), Canes-Wrone (2006), Canes-Wrone \& Shotts (2004), Cohen (1995), Geer (1996), Heith (2004), Hobolt \& Klemmensen (2006), Rottinghaus (2006), Wlezien \& Soroka (2007), and Page \& Shapiro.
} 
engaged in a public campaign to win Africans to its side not because it has been spurred on by its domestic public, but as a response to American fears about China.

\section{The Future of the U.S. And China in Africa}

According to Howard French (2014), China is “clearly competing with someone and for something - global preeminence” as evidenced by “a preference for giant projects that serve as constant highly visible reminders of China's reach, its power, and of its supposed generosity and solicitude,” along with its investment in African media and Confucius Institutes. French related a story from the Chinese ambassador to Zambia, Zhou Yuxiao, who said he "felt sorry" for his American counterpart in Zambia because he could not point to anything physical to demonstrate U.S. assistance (p. 262). Chinese activities appear to have provoked the kind of status anxiety which might cause a dominant state to “impede the new arrivals' advancement, to conserve superiority in the areas in which it is still ahead, and to recoup losses in those in which it has fallen behind” (Onea, 2014, p. 133). This appears to be the case after 2011 for the U.S. in Africa.

Interviewees saw a range of possible futures for the U.S. and China and U.S. and Africa. Respondent A said, "engagements will increase significantly. As I said, there is plenty of opportunity (and need) for all.” Respondent B said that both will deepen relations based on their own interests. Respondent C said, "both the U.S. and China will be increasingly active in the continent. Africa will be in a position to define the rules of engagement with both parties for more win-win partnerships.” 


\section{Respondent D said:}

I certainly hope that U.S. - African relations will continue to increase and to deepen in the future, with a corresponding greater American awareness of and familiarity with Africa in the future. I would note that I believe continuing immigration from Africa to the U.S. as well as (hopefully) wise political, economic, and other policies will reinforce this trend. Chinese/African relations will certainly continue to grow as well given China’s growing world role. I believe, however, that Chinese policies and models will inevitably need to be modified over time reflecting what I think are going to be political and other changes in China itself, as well as an evolving Chinese role as a political global player, with resultant changes in its relationships with other regions and countries of the world as well. Successful U.S. policy in Africa will require continuous monitoring, assessment, and adjustments as needed relative to China's roles and policies in Africa, as well as developments in Africa itself. While China’s continuing emergence as a true world power will clearly involve divergence with U.S. interests, and other areas of friction, I think it is a major mistake to think of China's relationship with Africa in strictly zero - sum or competitive terms relative to U.S./African relations. As such, I think it's important for U.S. policymakers to be attentive to opportunities to utilize overlapping or complementary U.S. and Chinese interests in Africa, as well as areas of competition or conflict, taking appropriate policy and program decisions reflecting both. 
Generally, respondents felt that the U.S. was not losing out to competitors in Africa. Respondent A said "U.S. companies want to compete fairly for business in Africa. And African governments like U.S. companies because they generally adhere to a set of core business values.” Respondent B directly stated that the U.S., China and Europe are not in direct competition with each other in Africa. Respondent C said that the U.S. has always had competitors in Africa" and that the interest other countries were showing Africa is not shared by the U.S. Thus, it is "unlikely that they fear losing the continent to competitors." Respondent D said that this 'fear' may exist for some; however, it is not generally the view of those most familiar with Africa. Many see opportunities and challenges for the U.S. in Africa, along with opportunities for some cooperation with China in various countries and situations. This respondent felt that competition between the U.S. and China would have to be analyzed at a specific region or country level.

This defense of the U.S. and refusal to see status competition, or loss of status, may reflect the vested interest officials generally have in seeing the U.S. in a positive light. This failure to recognize status may indeed hurt the U.S. in this and a variety of situations.

\section{$\underline{\text { Conclusion }}$}

David Lampton (2001) argued that "American and Chinese politicians use the outside world as a prop in their respective domestic theaters, hoping to convert perceived foreign-policy successes into improved domestic fortunes” (p. 280). In this fourth and final observed outcome, it appears that the U.S. pivoted toward Africa in about 2011, not because it believed that Africa was a land of opportunity but because it recognized economic and power losses occurring there, to China. This pivot involved a public 
campaign designed to win African leaders back to its side, by casting the U.S. as a better partner than China. Because this pivot cannot be justified by actual opportunity in Africa for the U.S., nor by strong domestic support, it may have been motivated by status competition with its largest competitor on the continent, China. 


\section{CHAPTER EIGHT: CONCLUSIONS AND DISCUSSION}

\section{Introduction}

This section will discuss the major patterns found in this case study, and how they relate to the literature review in Chapter Two. It will then discuss the original hypotheses, as well as competing explanations that could account for these findings. Finally, it will discuss the practical and theoretical implications of this study, and areas for future research.

\section{$\underline{\text { Hypotheses and Competing Explanations }}$}

There were three possible hypotheses put forward at the beginning of this study. They were:

(1) The U.S. is engaging in similar activities as the Chinese in and regarding Africa, and these activities appear to be a form of status competition.

(2) While the U.S. is engaging in activities in and regarding Africa in similar ways and/or locations to the Chinese, American activities and concerns do not appear to be a form of status competition.

(3) The U.S. and China are engaging in distinct, separate activities in Africa and these activities have no relationship to status competition. 
Based on the outcomes observed in this study, the greatest support appears to be for Hypothesis 1. If the U.S. had continued to neglect Africa through to the present, or had continued its normal activities with no sign of deviation, Hypotheses 2 and 3 might have been relevant. However, the U.S. markedly changed direction in about 2011, engaging in a number of new activities, including a major summit and two presidential trips. This new attention could have been due to rising U.S. economic interest in the continent; however, it appears American businesses and consumers continued to be disinterested in engagement with Africa. Therefore, these activities appear to have been status-related, as shown in Chapter Seven. Further discussion is shown in the next section, Patterns and Themes.

\section{$\underline{\text { Patterns and Themes }}$}

The major pattern found in this case study was that the U.S. appeared delayed in reacting to regional competition in Africa from its rising challenger there, China, until it understood that competition to be status-based. This delay may have been due to a number of factors, not explored fully in this case study, including pre-occupation with more direct challenges in the international system and from China, an inability to recognize this particular form of status competition, and perhaps overextension. Nevertheless, there is a clear progression of reaction on the part of U.S. leaders as Chinese activities expanded in Africa. First, there was a split between the reactions of Congresspeople and diplomats onthe-ground, who were concerned about China in Africa around the year 2005, and leaders in the White House and State Department, who publicly denied there was any kind of problem. White House and State Department leaders' reaction then grew somewhat as relative gains concerns were activated by economic and power losses in Africa. These 
leaders then engaged in quiet diplomacy with China and Africa, perhaps to try to "socialize" China and to moderate its less favorable activities. The U.S. at this time did not seem to be fully aware of the status threat China was presenting.

However, in about 2011, the U.S. appears to have begun to perceive the status losses it had sustained with Africa, China and the world, over Chinese activities in Africa. Through policy changes, discourse, summitry and public diplomacy, including social media, leaders launched what appeared to be a public campaign, designed to position the U.S. as opposed to the values of China, and as a better partner for Africans. This can be seen as status competition because the U.S. had little to gain economically in Africa and its domestic public remained unconcerned with Africa. Loss of status appears to have motivated the U.S. to take action when nothing else had, inspiring policy changes in Africa, the first-ever U.S.-Africa Leaders Summit, two presidential trips to Africa, and a public diplomacy campaign designed to showcase American strengths.

This is consistent with status theories presented in Chapter Two. Status is the result of collective, subjective and relative beliefs, which other actors come to understand voluntarily. It cannot be forced or coerced but must be won. In this case, China can be seen as a revisionist actor, attempting to gain status in Africa and in the world, while the U.S. can be seen as defensive, or working to protect or regain its high status. It is appropriate that the U.S. responded to loss of status in Africa with a campaign to persuade and influence Africans that it was a superior partner. Since the attack was perceived as status-related, actual economic gain for the U.S. would not be a determining factor in mounting a response. 
A successful hegemon cannot be shown to be deficient in any one area of the globe, and especially not to a rising challenger. Wohlforth (2009) noted that status can sometimes cause people or states to "behave in ways that directly contradict their material interest in security and/or prosperity” (p. 35). A hegemon able to claim high status in all parts of the globe will be able to compel respect and deference, reduce its costs, and see its core values and beliefs spread to every corner.

For the U.S. in particular, in a time of perceived decline, holding onto every bit of status has become more vital. U.S. leaders have often been able to turn to Africa to find support, or at least less anti-Americanism, than in other parts of the world. To lose this would see the U.S. edge ever closer to the precipice of loss of dominance globally. Deborah Larson and Alexei Shevchenko (2014) noted that a declining power will be less likely to passively accept status loss, or to accept any increase in the challenger's status. It will fight to maintain its high status, and any losses will be painful. This also supports Andrew Bacevich's (2002) argument that U.S. foreign policy is based on the U.S. being the only state capable of leading a global order fueled by its "universal" values. To find that a territory once so firmly in America's pocket has turned to its rising challenger seems to have been galling enough to the U.S. to provoke a reaction.

Further, a high status state may find any attempt by a challenger to close the gap between how it perceives itself and how others perceive it (status dissonance) extremely threatening and aggressive. The only way out of this cycle is for the higher status state to revise its idea of itself and its opponent, or for the lower status state to recognize the other's superiority (Wohlforth, 2014, p. 118). Fear that a lower status state is gaining on a higher status state provokes status anxiety for the latter. It will then try to block the challenger, 
keep its superiority where it can, and recoup any losses it has suffered (Onea, 2014, p. 133).

All of this appears to be borne out by the American reaction in 2011 and beyond to Chinese activities in Africa.

The use of public diplomacy to counteract Chinese activities is appropriate, especially as China tends to work government-to-government (official diplomacy). This type of communication with foreign publics is a way for the U.S. to differentiate itself and perhaps create a groundswell of support. The types of public diplomacy seen in this case study are of the "new" variety, with a focus on dialogue. This was certainly seen in the American approach to the U.S.-Africa Leaders Summit, highly touted as based on real African needs and clearly opposed to the formalized way the Chinese have conducted their summits. It has also been seen in innovative on-the-ground public diplomacy programs, and in the regional press hub set up to work more closely with African journalists. The State Department in particular has embraced social media. The ways the U.S. has used public diplomacy line up with theoretical ideas about the purposes of this type of communication, which include advancing national interests and values, influencing foreign publics and governments, improving general public opinion, enhancing the national image and increasing soft power and democracy (Fitzpatrick, 2010, p. 93-94).

Power-transition theory does not seem to be adequate in explaining the types of competition a hegemon and a rising power will face in the current international system. The competition between the hegemon and its rising challenger appears to be much subtler than predicted by this theory. Tied down by economic interdependence, constrained from going to war by norms and nuclear weapons, and challenged from many directions by China, the U.S. seems to not only be careful in its approach, but also sometimes to be 
surprised by new forms of competition between the two. By failing to recognize the status component of U.S.-China competition in Africa, the U.S. seems to have lost ground there. A strong, rising challenger cannot be viewed the same as any other economic actor. This is why Malaysia can carry out as many activities as it would like in Africa with little for the U.S. to fear. It is not only the magnitude of China's activities in Africa that challenges the U.S., but also the fact that it is an extension of the hegemon/rising state dynamic, where the hegemon is in decline and fears losing control of the international system to a challenger with differing values. This is likely what has caused the U.S. to finally react strongly in Africa: the recognition, no matter how delayed, that China has been challenging U.S. dominance and has been winning. It is perhaps a test case, a way for the U.S. to see the many ways in which a rising state might challenge a hegemon, and to better prepare itself for a new kind of power transition.

\section{Practical and Theoretical Implications}

The practical implications of this research involve knowing when and how status concerns may come into play. For instance, outer dynamics, such as a power struggle for dominance in the international system, may affect status competition in smaller arenas in very subtle ways. Including status competition as a dimension when looking at state-tostate relations may help explain otherwise mystifying actions. 
Status concerns are very deeply held and seem to operate at a level not always obvious to leaders and officials themselves, as seen in responses to the elite structured interviews in this case study. A state which has refused to become involved in a region or in a specific policy area may indeed do so if its status is threatened. In this case study, the U.S. appeared reluctant to take action until it understood that its high status in Africa had been threatened by a very specific kind of competitor.

The theoretical implications of this research affect both power-transition theory and status theories. Power-transition theory should be modified to include variables such as economic interdependence, norms among great powers and nuclear deterrence. These variables affect the likelihood of outright conflict and may shunt competition into new arenas. One of these arenas appears to be competition for status dominance in the international system, sometimes achieved in ingenious new ways not easily recognized by the hegemon. Status theories should be updated to account for the dynamic of a hegemon/rising challenger situation. While some work has been done on this, understanding and predicting the reactions of the hegemon when its status is challenged is an area ripe for research. This case study points to a delayed reaction, which can hurt the hegemon's chances of retaining its high status long-term. Also, more study on how lowstatus states can improve their standing in areas neglected by the hegemon is needed. 


\section{Policy Implications}

As the U.S. moves forward, there are several policy directions it might take. This section will detail the implications of those policies.

Should the U.S. decide to update its overall foreign policy toward Africa in order to regain or maintain high status in the region, it may decide to move away from an economic narrative and move toward its humanitarian and democratic roots. It has certainly become clearer that American companies and portions of the U.S. government are not deeply interested in sustaining or supporting this thread. The U.S. may prefer China to do the "heavy lifting" on addressing African supply-side manufacturing issues, transportation and trade infrastructure. By ceding this category to China publicly the U.S. could withdraw itself from comparison and status competition. This tacit agreement to stay within separate spheres of influence would allow both the U.S. and China to cement their reputations without fearing status loss.

If the U.S. decides to continue with a strong focus on public diplomacy in Africa, through social media especially, it may choose to use these avenues to advertise its activities in direct contrast to China's activities. This would involve moving beyond general, stereotypical claims that China is involved in neocolonial resource extraction, to actual deals and contracts, meetings, Xinhua news stories, cultural events, etc. If this were the case, the U.S. could begin to make up for some status loss by taking the challenges China offers head on, and providing clearer, more targeted messaging. Should this occur, the U.S. would likely be able to more effectively combat status loss.

Should the U.S. decide to integrate African counterterrorism into U.S.-Africa policy more fully, it may also be able to use public diplomacy to enhance transparency. 
The U.S. might then also be able to investigate whether counterterrorism has helped or hindered its status in Africa. If the latter, the U.S. might decide to continue the strong focus, but use it as a differentiating marker between itself and China.

The incoming American president will have to decide whether the U.S.-Africa Leaders Summit will be a regular occurrence. Should it continue, the U.S. will likely find that the summit will help regain status loss. The nature of the 2014 summit was consultative and distinctly American, although it successfully imitated China's main diplomatic activity in Africa, FOCAC, enough to be put in the same category for comparison. However, should the U.S. hold the summit again in the future, and decide to offer business contracts at the end, it may find that it is not as successful. Developing a separate sphere of influence from China will be more useful.

Should the U.S. decide to upgrade its American diplomatic corps in Africa, and train them specifically on how to counter China's activities in Africa, it will likely be able to regain a significant amount of status. Holding mini-summits with leaders on a regular basis, where those leaders might learn about opportunities the U.S. offers, or be provided with facts about on-the-ground Chinese deals or proposals, might persuade leaders of the value of the U.S. as compared to China. This upgraded diplomatic corps could also feed direct information on China's activities back to Washington.

Should the U.S. decide to keep conditionalities on loans, aid and AGOA in place, it may find itself facing power losses in the short-term. However, these differentiate the U.S. from China, and although they have been viewed negatively, in fact they demonstrate an American standard that might be perceived as a quality benchmark. Paying attention to marketing these conditions as positive benchmarks may help the U.S. in the long-term to 
be perceived as a stronger partner. This may be better directed at African publics, whose support may overcome or change shortsighted African governments who view China as an easier partner.

Should the U.S. make efforts to engage, excite and inform the American domestic public about the real Africa, beyond stereotypes, it will likely gain domestic support for U.S.-Africa foreign policy. This might involve bringing dominant stereotypes out and debunking them, capturing the attention of the news and other media on topics other than the latest African crisis, and showcasing the positive work being done by the U.S. there. An example of a hashtag campaign designed to show the positive side of living in Africa (which is not sponsored by the U.S. government) is \#TheAfricatheMediaNeverShowsYou.

\section{Further Topics of Research}

Future studies should continue to follow developments among the U.S., China and Africa over the next five to ten years. Will the U.S. continue to focus on Africa as a response to Chinese activities? How will the direct U.S.-China relationship change or grow as a reflection of activities in Africa, or how will U.S.-China activities outside of Africa, affect Africa? Will China's economic slowdown cause it to pull back its activities in Africa, leaving a political space for the U.S. to fill? If so, what will the U.S. do with that space?

Studies might also focus on the U.S.-Africa relationship, and whether the current interest truly is primarily status-based, or is based on a change in perception of the value of Africa. The American domestic population might be studied to note changes in their perception, and whether this aligns with leaders' actions. 
Finally, further study of power-transition theory and status theories will add to our understanding of how states vie for dominance in the current international system. Are there other situations in which a stronger state and weaker state do not face status concerns? How do those situations differ from the one examined in this case study? 


\section{LIST OF REFERENCES}

\$150 Oil: Instability, Terrorism and Economic Disruption: Hearing before the Committee on Foreign Relations, Senate, $111^{\text {th }}$ Cong. (2009) (Testimony of P. Carter).

Achiraya, A. (2003/4). Will Asia's Past Be Its Future? International Security, Winter 2003/4, pp. 149-164.

Africa-China-U.S. Trilateral Dialogue Summary Report. (2007). The Brenthurst Foundation, the Chinese Academy of Social Sciences, the Council on Foreign Relations and the Leon H. Sullivan Foundation.

Africa's Energy Potential: Hearing before the Subcommittee on Africa, House of Representatives, $107^{\text {th }}$ Cong. (2000) (Testimony by C. Humphrey, E. Royce, J. West).

African Development Bank (2012). Annual Development Effectiveness Review 2012. Retrieved from: http://www.afdb.org/fileadmin/uploads/afdb/Documents/Project-andOperations/ADER\%202012\%20(En).pdf Accessed October 15, 2015.

African Opinion on U.S. Policies, Values and People: Joint Hearing before the Subcommittee on International Organizations, Human Rights, and Oversight and the Subcommittee on Africa and Global Health, House of Representatives, $110^{\text {th }}$ Cong. (2007) (Testimony by D. Moehler and T. Tancredo).

AidData.org. (2014). http://china.aiddata.org/aggregates/export. Accessed October 21, 2014.

Akita, H. (2014, July 22). A New Kind of ‘Great Power Relationship?’ No Thanks, Obama Subtly Tells China. Nikkei Asian Review.

Akuetteh, C., Anderson, J., Liser, F. (2013, July 31). Preview of the 2013 African Growth and Opportunity Act (AGOA) Forum.

Alagappa, M. (2003). (ed). Asian Security Order: Instrumental and Normative Features. Stanford, CA: Stanford University Press.

Alden, C. (2005). China in Africa. Survival, Vol. 47, No. 3, pp. 147-164.

Alessi, C. and Hanson, S. (2012). Expanding China-Africa Oil Ties. The Council on Foreign Relations. Retrieved from: http://www.cfr.org/china/expanding-china-africa-oilties/p9557. Accessed October 21, 2014.

Alessi, C. and Xu, B. (2015, April 27). China in Africa. The Council on Foreign Relations. 
Aljazeera (2014, May 6). China and Ethiopia Sign Major Deals.

AllAfrica.Com (2014, May 8). Kenya-China Relations: A Journey of Friendship and Cooperation. Retrieved from: http://allafrica.com/stories/201405090309.html Accessed October 15, 2015.

AllAfrica.Com (2015, April 1). Africa: Spotlight - China’s Peacekeeping Contribution to U.N. Missions in Africa Shows Growing Sense of Responsibility. Retrieved from: http://news.xinhuanet.com/english/2015-03/27/c 134104184.htm Accessed October 15, 2015.

An Overview of U.S. Policy in Africa: Hearing before the Subcommittee on Africa and Global Health, House of Representatives, $111^{\text {th }}$ Cong. (2010) (Testimony of J. Carson).

Anthony, R. (2013, June 26). Obama 'Playing Catch-Up,' As Africa Looks to China. CNN.

Arms Control Association (2015). Nuclear Weapons: Who Has What at A Glance. http://www.armscontrol.org/factsheets/Nuclearweaponswhohaswhat Accessed September 25, 2015.

Art, R. (2010). The United States and the Rise of China: Implications for the Long Haul. Political Science Quarterly. Volume 125, No. 3, pp. 359 - 391.

Assessing China's Behavior and its Impact on U.S. Interests: Briefing before the Committee on Foreign Affairs, House of Representatives, $112^{\text {th }}$ Cong. (2011) (Testimony of H. Berman and R. Sutter).

Assessing China's Role and Influence in Africa: Hearing before the Subcommittee on Africa, Global Health, and Human Rights, House of Representatives, $112^{\text {th }}$ Cong. (2012) (Testimony by J. Fortenberry, S Hayes, J. Lee, J. Pham, and D. Yamamoto).

Assessing the Fiscal Year 2012 Budget for Africa: Hearing before the Subcommittee on African Affairs, Senate, $112^{\text {th }}$ Cong. (2011) (Testimony by R. Jandhyala and P. Fine).

Assessing U.S. Foreign Policy Priorities and Needs Amidst Economic Challenges: Hearing before the Committee on Foreign Affairs, House of Representatives, $112^{\text {th }}$ Cong. (2011) (Testimony of H. Berman).

Aziz, N. (2003). Race[e]ing Abroad: Exploring Racism in/and U.S. Foreign Policy. Retrieved from http://www.politicalresearch.org/2003/03/01/raceing-abroad-exploringracism-inand-u-s-foreign-policy/\#sthash.XnCBIfQK.dpbs Accessed January 31, 2016. 
BBC (2015). China Profile - Timeline. Retrieved from: http://www.bbc.com/news/worldasia-pacific-13017882 Accessed October 14, 2015.

BBC (2015, October 27). IMF Warns of African Economic Slowdown. Retrieved from: http://www.bbc.com/news/business-34648409 Accessed October 15, 2015.

BBC Africa (2012, January 28). African Union Opens Chinese-Funded HQ in Ethiopia. Retrieved from: http://www.bbc.com/news/world-africa-16770932 Accessed October 15, 2015.

BBC China (2015, February 6). China Media Criticise Dalai Lama-Obama Meeting. Retrieved from: http://www.bbc.com/news/world-asia-china-31159993 Accessed October 15, 2015.

Bacevich, A. (2002). American Empire: The Realities and Consequences of U.S. Diplomacy. Cambridge, MA: Harvard Univ. Press.

Bader, J. (2012). Obama and China's Rise: An Insider's Account of America's Asia Strategy. Washington, DC: Brookings Institution Press.

Baker, P. (2015, July 29). Obama, on China’s Turf, Presents U.S. as a Better Partner for Africa. New York Times.

Baker, P. and Santora, M. (2015, July 24). Obama Arrives in Kenya, on Personal and Official Journey. New York Times.

Baogang, G. and Teng, C. (2011). China's Quiet Rise. Lanham, MD: Lexington Books.

Barma, N. and Ratner, E. (2006). China’s Illiberal Challenge. Democracy. Issue \#2, Fall 2006.

Becker, A. (2010). China Summons Past to Advance into Africa. Inter Press Service News Agency.

Bennes, B. (2012). U.S. Investment in Africa: Making Up for Lost Ground. Africa.Com. Retrieved from: http://www.africa.com/blog/u_sinvestment_in_africa_making_up_for_lost_ground/ Accessed October 15, 2015.

Bernstein, R. and Munro, R. (1997). The Coming Conflict with China. New York, NY: Alfred A. Knopf.

Beyond Oil and Gas: African Growth and Opportunity Act's Benefits to Africa: Hearing before the Subcommittee on Africa and Global Health, House of Representatives, $110^{\text {th }}$ Cong. (2007) (Testimony by J. Fortenberry, F. Liser, E. Royce). 
Beuret, M. and Michel, S. (2009). China Safari: on the Trail of China's Expansion in Africa. New York, NY: Nation Books.

Bjola, C. \& Jiang, L. (2015). Social Media and Public Diplomacy: A Comparative Analysis of the Digital Diplomatic Strategies of the E.U., U.S. and Japan in China in (Eds.) Corneliu Bjola and Marcus Holmes. Digital Diplomacy: Theory and Practice. New York: Routledge.

Blosser, J. (2015, May 26). China Warns War May Be Coming with U.S. Newsmax.

Boyd-Barrett, O. (2014). Media Imperialism. Thousand Oaks, CA: SAGE Publications.

Brautigam, D. (2009). The Dragon's Gift: The Real Story of China in Africa. Oxford: Oxford University Press.

Brennan, L. (2015, May 29). New World Order in Space - China Stands Out. CNN.

Bridges Africa (2015, September 3). Mixed Consensus Emerges at AGOA Forum. Retrieved from: http://agoa.info/news/article/5833-mixed-consensus-emerges-at-agoaforum.html Accessed October 26, 2015.

Broadcasting Board of Governors (2015). Fiscal Year 2015 Congressional Budget Request. Retrieved from: http://www.bbg.gov/wp-content/media/2014/03/FY-2015BBG-Congressional-Budget-Request-FINAL-21-March-2014.pdf Accessed October 15, 2015.

Brookes, P. \& Shin, J. H. (2006). China’s Influence in Africa: Implications for the United States. The Heritage Foundation. Retrieved from: http://www.heritage.org/research/reports/2006/02/chinas-influence-in-africaimplications-for-the-united-states. Accessed October 21, 2014.

Brzezinski, Z. (2012). Strategic Vision: America and the Crisis of Global Power. New York, NY: Basic Books.

Burman, E. (2008). China: The Stealth Empire. Stroud: The History Press Ltd.

Burstein, P. (2003). The Impact of Public Opinion on Public Policy: A Review and an Agenda Political Research Quarterly, March, 56, 1, pg. 29.

Bush, G.W. (2000). October 11, 2000 Debate. Commission on Presidential Debates. Retrieved from: www.debates.org/?page=october-11-2000-debate-transcript. Accessed April 13, 2015.

Bush, G.W. (2000). PBS News Hour Interview. The White House. 
Bush, G.W. (2001, May 16). Remarks by the President at African Growth and Opportunity Act Trade and Economic Cooperation Forum. The White House.

Bush, G.W. (2003, January 15). President Addresses African Growth and Opportunity Act Forum. The White House.

Bush, G.W. (2003, July 12). President Bush Concludes Week Long Trip to Africa. The White House.

Bush, G.W. (2003, June 26). President Bush Outlines His Agenda for U.S.-African Relations. The White House.

Bush, G.W. (2003, July 3). President Bush Discusses Upcoming Africa Trip with Reporters. The White House.

Bush, G.W. (2003, July 12). President’s Radio Address. The White House.

Bush, G.W. (2003, September 23). U.N. General Assembly Speech, $58^{\text {th }}, 7^{\text {th }}$ Plenary. The United Nations.

Bush, G.W. (2003, October 6). President Bush, Kenyan President Kibaki Discuss State Visit. The White House.

Bush, G.W. (2004, September 21). U.N. General Assembly, 59 ${ }^{\text {th }}$, $3^{\text {rd }}$ Plenary. The United Nations.

Bush, G.W. (2005, June 10). Message by the President to the People of Africa. Voice of America.

Bush, G.W. (2005, June 30). President Discusses G8 Summit, Progress in Africa. The White House.

Bush, G.W. (2005, September 14). U.N. General Assembly, 60 ${ }^{\text {th }}$, ${ }^{\text {nd }}$ Plenary. The United Nations.

Bush, G.W. (2006, June 15). President Attends Initiative for Global Development’s 2006 National Summit. The White House.

Bush, G.W. (2006, September 19). U.N. General Assembly, 61 ${ }^{\text {st }}, 10^{\text {th }}$ Plenary. The United Nations.

Bush, G.W. (2007, September 25). U.N. General Assembly, 62 ${ }^{\text {nd }}, 4^{\text {th }}$ Plenary. The United Nations. 
Bush, G.W. (2008, February 14). President and Mrs. Bush Discuss Africa Policy, Trip to Africa. The White House.

Bush, G.W. (2008, February 16). President Bush Participates in Joint Press Availability with President Yayi of Benin. The White House.

Bush, G.W. (2008, February 17). President Bush Participates in Joint Press Availability with President Kikwete of Tanzania. The White House.

Bush, G.W. (2008, February 19). President Bush and President Kagame of Rwanda Dedicate United States Embassy Kigali. The White House.

Bush, G.W. (2008, February 20). President Bush Participates in Press Availability with President Kufuor of Ghana. The White House.

Bush, G.W. (2008, September 23). U.N. General Assembly 63 ${ }^{\text {rd }}$, $5^{\text {th }}$ Plenary. The United Nations.

Butty, J. (2012, January 10). Assessing Obama’s Africa Policy, Looking at 2012 and Beyond. Voice of America.

Buzan, B. (2004). The United States and Great Powers: World Politics in the TwentyFirst Century. Cambridge: Polity Press.

Calmes, J. (2015, October 27). House Votes Overwhelmingly to Reopen the Ex-Im Bank. The New York Times.

Campbell, H. (2008) China in Africa: Challenging U.S. Global Hegemony. Third World Quarterly, 29:1, 89-105.

Campbell, K. and Andrews, B. (2013) Explaining the U.S. 'Pivot' To Asia. London: Chatham House. Retrieved from: https://www.chathamhouse.org/sites/files/chathamhouse/public/Research/Americas 10813pp_pivottoasia.pdf Accessed October 15, 2015.

Canes-Wrone, B. and Shotts, K. (2004). The Conditional Nature of Presidential Responsiveness to Public Opinion. American Journal of Political Science, Vol. 48, No. 4 (Oct. 2004), pp. 690-706.

Canes-Wrone (2006). Who Leads Whom? Presidents, Policy, and the Public. Chicago, IL: University of Chicago Press.

Carmody, P. and Owusu, F. (2007). Competing Hegemons? Chinese versus American Geo-Economic Strategies in Africa. Political Geography, 26, pp. 504-524. 
Carney, J. (2013, June 26). Press Gaggle by Press Secretary Jay Carney Aboard Air Force One en route Senegal. The White House.

Carson, J. (2009, April 29). Statement Before the Senate Committee on Foreign Relations. The U.S. State Department.

Carson, J. (2009, May 12). Assistant Secretary Carson’s Press Conference in Nairobi. The U.S. State Department.

Carson, J. (2009, June 25). Remarks Before the Council on Foreign Relations. The U.S. State Department.

Carson, J. (2009, July 30). Briefing on Secretary Clinton’s Upcoming Trip to Africa. The U.S. State Department.

Carson, J. (2009, August 11). Remarks En Route Abuja, Nigeria. The U.S. State Department.

Carson, J. (2010, February 24). Assistant Secretary Carson's Recent Two Week Tour of Africa at the Foreign Press Center. The U.S. State Department.

Carson, J. (2010, June 14). Diplomacy Briefing Series: Conference on Sub-Saharan Africa. The U.S. State Department.

Carson, J. (2012, June 13). Briefing on U.S. Trade and Investment Policy in Africa and the Upcoming AGOA Forum. The U.S. State Department.

Carter, P. III (2009, February 9). U.S. Africa Policy in the $21^{\text {st }}$ Century. The Africa Center for Strategic Studies.

Center for Public Diplomacy Blog (2012). U.S. Leadership Still Viewed Positively, But with Major Declines in Africa. USC Center for Public Diplomacy. Retrieved from: http://uscpublicdiplomacy.org/blog/us_leadership_still_viewed_positively_but_wit h_major_declines_in_africa Accessed October 1, 2015.

Center for Public Diplomacy Blog (2013, October 10). U.S. Public Diplomacy in Africa: Two Public Diplomacies. Retrieved from: http://uscpublicdiplomacy.org/blog/us-publicdiplomacy-africa-two-public-diplomacies Accessed October 1, 2015.

Chan, S. (2008). China, the U.S. and Power-Transition Theory: A Critique. New York, NY: Routledge.

Changing Energy Markets and U.S. National Security: Hearing before the Subcommittee on Terrorism, Nonproliferation, and Trade, House of Representatives, $112^{\text {th }}$ Cong. (2011) (Testimony by E. Royce). 
Chau, D. (2006). Political Warfare - an Essential Instrument of U.S. Grand Strategy Today. Comparative Strategy, 25:2, 109-120.

Cheng, T. (2013). U.S.-China Relations: A New Type of Great Power Relationship? Prepared for the 2013 Taiwan-U.S.-Japan Trilateral Security Dialogue.

China Daily (2015). Backgrounder: Five Principles of Peaceful Coexistence. Retrieved from: http://www.chinadaily.com.cn/world/2015xivisitpse/201504/22/content_20509374.htm Accessed October 12, 2015.

China in Africa: Implications for U.S. Policy: Hearing before the Subcommittee on African Affairs, Senate, $110^{\text {th }}$ Cong. (2008) (Testimony of E. Economy, R. Feingold, J. Morrison, J. Swan and T. Christensen).

China's Approach to the East, North and the Horn of Africa: Hearing before the U.S.China Economic and Security Review Commission (2005) (Testimony by D. Shinn).

China's Influence in Africa: Hearing before the Subcommittee on Africa, Global Human Rights and International Operations, House of Representatives, $108^{\text {th }}$ Cong. (2005) (Testimony by C. Bartholomew, B. Lee, D. Payne, M. Ranneberger, E. Wilson and C. Smith).

China's Role in Africa: Implications for U.S. Policy: Hearing before the Subcommittee on African Affairs, Senate, $112^{\text {th }}$ Cong. (2011) (Testimony of D. Brautigam, C. Coons, S. Hayes, J. Isakson and D. Shinn).

Chiu, E. and Willett, T. (2012) Measuring Power and the Rise of East Asia. Claremont Graduate University Working Paper.

Chutha, R. and Kimenyi, M. (2011). The Africa Growth and Opportunities Act: Toward 2015 and Beyond. Africa Growth Initiative at The Brookings Institution. Washington, DC.

Clingan, E. (2013). Twilight's Last Gleaming: American Hegemony and Dominance in the Modern World. Lanham, MD: Lexington.

Clinton, H. (2009, August 5). Remarks at the $8^{\text {th }}$ Forum of the African Growth and Opportunity Act. The U.S. Department of State.

Clinton, H. (2009, August 6). Interview with Bill Odidi of Metro FM. The U.S. Department of State.

Clinton, H. (2009, August 6). Townterview Hosted by CNN and KTN at the University of Nairobi. The U.S. Department of State. 
Clinton, H. (2009, August 10). Town Hall with Search for Common Ground and Congolese University Students. The U.S. Department of State.

Clinton, H. (2009, August 8). Remarks Following Meeting Between Secretary Clinton and President Zuma. The U.S. Department of State.

Clinton, H. (2009, October 1). Remarks at the Corporate Council on Africa's Seventh Biennial U.S.-Africa Business Summit. The U.S. Department of State.

Clinton, H. (2010, January 6). Remarks on Development in the $21^{\text {st }}$ Century. The Center for Global Development.

Clinton, H. (2010, May 27). Remarks on the National Security Strategy. The U.S.

Department of State.

Clinton, H. (2010, June 14). U.S. Priorities for Sub-Saharan Africa at Diplomacy Briefing Series: Conference on Sub-Saharan Africa. The U.S. Department of State.

Clinton, H. (2011, June 11). Interview on Africa 360. The U.S. Department of State.

Clinton, H. (2011, September 9). Smart Power Approach to Counterterrorism. John Jay School of Criminal Justice, New York.

Clinton, H. (2012, August 7). Remarks at Meeting with U.S. and South African Business Leaders. The U.S. Department of State.

Clinton, H. (2012, August 8). The United States - South Africa Partnership: Going Global in Cape Town, South Africa. The U.S. Department of State.

Clotty, P. (2012, August 22). Africa Has Bright Future Says Obama’s Former Chief of Staff. Voice of America.

Clough, M. (1992). Free at Last? U.S. Policy Toward Africa and the End of the Cold War. New York: Council on Foreign Relations Press.

Cohen (1995) Presidential Rhetoric and the Public Agenda American Journal of Political Science, Vol. 39, No. 1 (Feb. 1995), pp. 87-107.

Cohen, M. and Vollgraaff, R. (2015, September 15). Africa’s Oversold Growth Story Has Investors Confronting Losses. Bloomberg Business.

Congressional Research Service Library of Congress (2008). China's Foreign Policy and 'Soft Power' In South America, Asia, And Africa: A Study Prepared for The Committee On Foreign Relations United States Senate. Washington, DC: U.S. Government Printing Office. 
Cooper, H. (2015 January 24). Rifts Between U.S. and Nigeria Impeding Fight Against Boko Haram. The New York Times.

Copley, A. (2015, October 9). Africa in the News: Ibrahim Index Shows Stalled Governance Progress, Slower African GDP Growth in 2015 Predicted, and U.S. Companies Lobby for Ex-Im Bank Reauthorization. The Brookings Institution.

Costs of War Project (2013). Iraq War: 190,000 Lives, \$2.2 Trillion. Retrieved from: https://news.brown.edu/articles/2013/03/warcosts. Accessed October, 5, 2015.

Cox, M. (2004). Empire? The Bush Doctrine and the lessons of history. In D. Held \& M. Koenig-Archibugi (Eds.), American Power in the Twenty-First Century. Cambridge, UK: Polity.

Creswell, J. W. (2007 \& 2013). Qualitative Inquiry \& Research Design: Choosing Among Five Approaches. Thousand Oaks, CA: Sage Publications.

Cull, N. (2008). The Cold War and The United States Information Agency: American Propaganda and Public Diplomacy, 1945-1989. Cambridge, UK.

Cull, N. (2009). How We Got Here in Seib, P. (Ed) Toward A New Public Diplomacy: Redirecting U.S. Foreign Policy. NY: Palgrave MacMillan.

Cull, N. (2010). Public Diplomacy: Seven Lessons for Its Future from Its Past, Place Branding and Public Diplomacy, Vol. 6, 1, 11-17.

Cylke, O. (2014, September 3). Africa, the Summit and Development. The Council on Foreign Relations.

d'Hooghe, I. (2005). Public Diplomacy in the People's Republic of China in Melissen, J. (ed) The New Public Diplomacy: Soft Power in International Relations. NY: Palgrave MacMillan.

d’Hooghe, I. (2014). China's Public Diplomacy. Brill-Nijhoff Publishers.

Dao, J. (2002). In Quietly Courting Africa, U.S. Likes The Dowry: Oil. The New York Times.

David, C.P. and Grondin, D. (2006). Hegemony or Empire? The Redefinition of U.S. Power Under George W. Bush. Burlington, VT: Ashgate.

Davies, C. (2015, July 29). Obama's Africa Trip Shows Contrast in U.S., China Foreign Policies. China Daily USA.

Davis, S. (2015, July 1). Congress Lets Export-Import Bank Expire. USA Today. 
Democratic Developments in Sub-Saharan Africa: Moving Forwards or Backwards? Hearing before the Subcommittee on African Affairs, Senate, $110^{\text {th }}$ Cong. (2007) (Testimony of A. Amosu, R. Feingold, R. Rotberg).

Denzin, N. and Lincoln, Y. (2003) (eds). The Landscape of Qualitative Research: Theories and Issues. Second Edition. London: Sage.

Ding, S. (2008). The Dragon's Hidden Wings: How China Rises with Its Soft Power. Lanham, MD: Lexington Books.

Donilon, T. (2011, January 14). Press Briefing by Treasury Secretary Tim Geithner, National Security Advisor Tom Donilon, and Press Secretary Robert Gibbs Previewing the Upcoming State Visit of President Hu of China. The White House.

Donnelly, T. and Monaghan, C. (2007). Legacy Agenda Part III: The Bush Doctrine and The Rise of China. Washington, DC: The American Enterprise Institute for Public Policy Research.

Downs, E. (2006). Brookings Foreign Policy Studies Energy Security Series: China. The Brookings Institution.

Drummond, P. and Xue, E. (2013). Africa's Rising Exposure to China: How Large Are Spillovers Through Trade” Working Paper. The International Monetary Fund.

Earnest, J. (2013, March 28). Press Briefing by Principal Deputy Press Secretary Josh Earnest. The White House.

Economic Statecraft: Embracing Africa's Market Potential: Hearing before the Subcommittee on African Affairs, Senate, $112^{\text {th }}$ Cong. (2012) (Testimony of J. Carson, J. Isakson, and F. Sanchez).

Economic Statecraft: Increasing American Jobs Through Greater U.S.-Africa Trade and Investment: Hearing before the Committee on Foreign Relations, Senate, $112^{\text {th }}$ Cong. (2012) (Testimony of C. Coons, R. Durbin and F. Hochberg).

Efforts to Deal with America's Image Abroad: Are They Working? Hearing before the Subcommittee on International Organizations, Human Rights, and Oversight, House of Representatives, $110^{\text {th }}$ Cong. (2007) (Testimony of L. Curtis and B. Delahunt).

Egbula, M. and Zheng, Q. (2011, November). West African Challenges: China and Nigeria: A Powerful South-South Alliance. OECD.

Eisenman, J. and Kurlantzick, J. (2006). China’s Africa Strategy. Current History. The Carnegie Endowment. 
Eisenman, J. and Shinn, D. (2008, June). Responding to China in Africa. American Foreign Policy Council.

Embassy of the United States, Zimbabwe (2015). U.S. Sanctions Policy: Facts and Myths. Retrieved from: http://harare.usembassy.gov/sanctions_facts_myths.html Accessed October 29, 2015.

Emerging Threat of Resource Wars: Hearing before the Subcommittee on Europe, Eurasia, and emerging threats, House of Representatives, $113^{\text {th }}$ Cong. (2013) (Testimony of Gen. J. Adams and D. Rohrabacher).

Energy Security: Historical Perspectives and Modern Challenges: Hearing before the Committee on Foreign Relations, Senate, $111^{\text {th }}$ Cong. (2009) (Testimony of J. Carter).

Energy Trends in China and India: Implications for the United States: Hearing before the Committee on Foreign Relations, Senate, $109^{\text {th }}$ Cong. (2005) (Testimony by E. Wayne).

Ensor, L. (2014, March 12). Bilateral Trade with China on the Increase. Business Day.

Evans, M. (2009). Power and Paradox: Asian Geopolitics and Sino-American Relations in The 21st Century. Revised version of a paper delivered to Asia Study Group at FPRI in May 2009.

Examining Prospects for Democratic Reform and Economic Recovery in Zimbabwe: Hearing Before the Subcommittee on African Affairs, Senate, $113^{\text {th }}$ Cong. (2013) (Testimony by E. Gast and D. Yamamoto).

Executive Research Associates (Pty) Ltd. (2009). China in Africa: A Strategic Overview. Institute of Developing Economies. Japan External Trade Organization.

Federal Democratic Republic of Ethiopia's Ministry of Foreign Affairs (2015). EthiopiaChina (PRC) Relations. Retrieved from: http://www.mfa.gov.et/BilateralMore.php?pg=9 Accessed October 20, 2015.

Feffer, J. (2003). Power Trip: U.S. Unilateralism and Global Strategy After September 11. New York, NY: Seven Stories Press.

Feingold, R. \& Thiam, T. (2005). The Commission for Africa Review. Senate Foreign Relations Committee.

Fettweis, C. (2010). Dangerous Times? The International Politics of Great Power Peace. Washington, DC: Georgetown University Press.

Fielding, A. (2015, June 22). China: Africa’s New Power Broker. The National Interest. 
Finnemore, M. and Sikkink, K. (1998). International Norm Dynamics and Political Change International Organization. Vol. 52, No. 4, pp. 887-917).

Firsing, S. (2012, May 4). A New ‘Rough Patch’ in U.S.-South Africa Relations. International Policy Digest.

Fitzpatrick, K. (2009). Privatized Public Diplomacy in Seib, P. (Ed) Toward A New Public Diplomacy: Redirecting U.S. Foreign Policy. NY: Palgrave MacMillan.

Fitzpatrick, K. (2009, February 17) Understanding PD: Toward a Common Identity. Paper presented at at the annual conference of the International Studies Association, New York, NY.

Fitzpatrick, K. (2010). The Future of U.S. Public Diplomacy: An Uncertain Fate. Leiden: Brill.

Fleischer, A. (2001, May 10). Press Briefing. The White House.

Foreign Aid and the Fight Against Terrorism and Proliferation: Leveraging Foreign Aid to Achieve U.S. Policy Goals: Hearing before the Subcommittee on Terrorism, Nonproliferation, and Trade, House of Representatives, $110^{\text {th }}$ Cong. (2008) (Testimony of D. Farah and E. Royce).

Foreign Policy and National Security Implications of Oil Dependence: Hearing before the Committee on Foreign Affairs, House of Representatives, $110^{\text {th }}$ Cong. (2007) (Testimony by E. Royce).

Forum on China-Africa Cooperation (2000). Beijing Declaration of the Forum on ChinaAfrica Cooperation. Retrieved from from www.focac.org on April 21, 2015.

Forum on China-Africa Cooperation (2000). Programme for China-Africa Cooperation in Economic and Social Development. Retrieved from www.focac.org on April 21, 2015.

Forum on China-Africa Cooperation (2003). Forum on China-Africa Cooperation Addis Ababa Action Plan. Retrieved from www.focac.org on April 21, 2015.

Forum on China-Africa Cooperation (2006). Declaration of the Beijing Summit of the Forum on China-Africa Cooperation. Retrieved from www.focac.org on April 21, 2015.

Forum on China-Africa Cooperation (2006). Forum on China-Africa Cooperation Beijing Action Plan. Retrieved from www.focac.org on April 21, 2015.

Forum on China-Africa Cooperation (2009). Declaration of Sharm El Sheikh of the Forum on China-Africa Cooperation. Retrieved from www.focac.org on April 21, 2015. 
Forum on China-Africa Cooperation (2009). Forum on China-Africa Cooperation Sharm El Sheikh Action Plan. Retrieved from www.focac.org on April 21, 2015.

Forum on China-Africa Cooperation (2012). Beijing Declaration of the Fifth Ministerial Conference of the Forum on China-Africa Cooperation. Retrieved from www.focac.org on April 21, 2015.

Forum on China-Africa Cooperation (2012). The Fifth Ministerial Conference of the Forum on China-Africa Cooperation Beijing Action Plan (2013-2015). Retrieved from www.focac.org on April 21, 2015.

Fouskas, V. and Gokay, B. (2005). The New American Imperialism: Bush's War on Terror and Blood for Oil. Westport, CT: Praeger Security International.

Frankfort-Nachmias, C. and Nachmias, D. (1996). Research Methods in The Social Sciences. $5^{\text {th }}$ ed. New York, NY: St. Martin's Press.

French, H. (2014). China's Second Continent: How a Million Migrants Are Building a New Empire in Africa. New York, NY: Alfred A. Knopf.

French, H. (2015, July 3). Is China in Africa Something to Fear? The Washington Post.

Friedberg, A. (1998). Europe's Past, Asia’s Future. SAIS Policy Forum Series, October 1998, no. 3.

Friedberg, A. (2005). The Future of U.S.-China Relations: Is Conflict Inevitable? International Security, Vol. 30, No. 2, pp. 7-45.

Friedberg, A. (2011). A Contest for Supremacy: China, America, and the Struggle for Mastery in Asia. New York, NY: W.W. Norton \& Co.

Froman, M. (2015, August 26). Remarks by Ambassador Michael Froman at the Opening Ceremony of the 2015 AGOA Forum. Office of the U.S. Trade Representative.

FY2012 Budget Request for U.S. Policies in Africa: Hearing before the Foreign Relations Subcommittee on African Affairs, Senate, $112^{\text {th }}$ Cong. (2011) (Testimony of J. Carson).

Garland, G. (2009, January 29). The U.S.-Africa Relationship and the Presidential Transition at the Florida Chautaqua. The White House.

Gatsiounis, I. (2012, March 22). No, China Will Not Usher in the Renaissance Africa Dreams of. Daily Monitor. 
Gavin, M, et. al. (2009, July 9). Press Briefing by Gibbs, Deputy National Security Advisor for Strategic Communications Denis McDonough and Senior Director for African Affairs Michelle Gavin. The White House.

Gavin, M. (2009, September 22). Press Briefing by Michelle Gavin, Senior Director for African Affairs, On the President's Lunch with Sub-Saharan African Heads of State. The White House.

Geer, J. (1996) From Tea Leaves to Opinion Polls. New York, NY: Columbia University Press.

Gibbs, R. (2010, April 26). Briefing by Press Secretary Robert Gibbs. The White House.

Gilboa, E. (1998). Media Diplomacy: Conceptual Divergence and Applications. The Harvard International Journal of Press/Politics, no. 3: 56.

Gill, B. and Reilly, J. (2007). The Tenuous Hold of China Inc. In Africa. The Washington Quarterly, 30:3, p. 37-52).

Gilpin, R. (1981). War and Change in World Politics. New York, NY: Cambridge University Press.

Glaser, B. (2013). The Diplomatic Relationship: Substance and Process in Shambaugh, D. (ed). Tangled Titans: The United States and China. Lanham, MD: Rowman \& Littlefield Publishers, Inc.

Goldstein, A. (2005). Rising to the Challenge: China's Grand Strategy and International Security. Stanford, CA: Stanford University Press.

Gordon, D., Miller, Jr., D. and Wolpe, H. (1998). The United States and Africa: A PostCold War Perspective. New York, NY: W.W. Norton \& Co.

Greenbank, P. (2003). The Role of Values in Educational Research: The Case for Reflexivity. British Educational Research Journal, vol. 29, no. 6.

Grieco, J. (1990). Cooperation Among Nations: Europe, America, and Non-Tariff Barriers to Trade. Ithaca, NY: Cornell University Press.

Gutsche, R. Jr. (2014). There’s No Place Like Home. Journalism Practice, Vol. 8, No. 1, p. 65-79.

Hadley, S. (2008, February 13). Press Briefing by National Security Advisor Stephen Hadley on the President's Trip to Africa. The White House. 
Hagos, A. (2000). Hardened Images: The Western Media and the Marginalization of Africa. Trenton, NJ: Africa World Press, Inc.

Hammer, M. (2012, November 5). Launching the Africa Regional Media Hub in Johannesburg. DipNote. U.S. Department of State.

Hanson, S. (2009, August 6). Corruption in Sub-Saharan Africa. The Council on Foreign Relations.

Hartig, F. (2015). Chinese Public Diplomacy: The Rise of the Confucius Institute. New York, NY: Routledge.

Hasenclever, A., Mayer, P., Rittberger, V. (1997). Theories of International Regimes. NY: Cambridge University Press.

Hasenclever, A., Mayer, P., Rittberger, V. (2000). Integrating Theories of International Relations Review of International Studies, Vol. 26, No. 1, pp. 3-33.

Hathway, R. (2008). U.S. Domestic Politics and The China Policy Rollercoaster in Zhao, S. (Ed). China and The United States: Cooperation and Competition in Northeast Asia. New York, NY: Palgrave Macmillan.

He, W. (2010). China's Aid to Africa: Policy Evolution, Characteristics and Its Role in Sorenson, J. (Ed). Challenging The Aid Paradigm: Western Currents and Asian Alternatives. New York, NY: Palgrave Macmillan.

Heith, D. (2004) Polling to Govern: Public Opinion and Presidential Leadership. Stanford, CA: Stanford University Press.

Hentz, J. (2004). The Contending Currents in United States' Involvement in Sub-Saharan Africa in Taylor, I. And Williams, P. (Eds). Africa in International Politics: External Involvement On the Continent. London: Routledge.

Hobolt, S. and Klemmensen, R. (2006) Government Responsiveness in Words and Action. Comparative Political Studies, 41; 309.

Hocking, B. (2004). Privatizing Public Diplomacy. International Studies Perspectives 5: 149.

Hocking, B. (2005). Rethinking The 'New' Public Diplomacy in Melissen, J. (Ed) The New Public Diplomacy: Soft Power in International Relations. New York, NY: Palgrave MacMillan. 
Holmes, M. (2015). Digital Diplomacy and International Change Management in (Eds.) Corneliu Bjola and Marcus Holmes. Digital Diplomacy: Theory and Practice. New York: Routledge.

Honey, M. (2003). The Archipelago of 'Evil’ In Feffer, J. (Ed). Power Trip: U.S. Unilateralism and Global Strategy After September 11. New York, NY: Seven Stories Press.

Hoye, M. and Yan, H. (2014, November 12). U.S. and China Reach Historic Climate Change Deal, Vow to Cut Emissions. CNN.

Hu, J. (2009, September 23). U.N. General Assembly Speech, 64 ${ }^{\text {th }}$. The United Nations.

Huck, P. (2014, August 23). China vs U.S. - Superpower Standoff in Africa. The New Zealand Herald.

Hurrell, A. (2006). Hegemony, Liberalism and Global Order: What Space for Would-Be Great Powers? International Affairs, Vol. 82, No. 1, pp. 1-19.

Hyde, D. and Froman, M. (2015, August 24). Unlocking Africa's Trade Potential. DipNote. U.S. Department of State.

Ikenberry, G. J. (2013). The Rise of China, United States and The Future of the Liberal International Order in Shambaugh, D. (ed). Tangled Titans: The United States and China. Lanham, MD: Rowman \& Littlefield Publishers, Inc.

Ilgen, T. (2006). Hard Power, Soft Power and Transatlantic Relations. Burlington, VT: Ashgate.

Ilunga, Y. (2015, February 25). Eye on Africa: U.S. and China Tussle for Economic Influence. The Conversation.

Index of National Power (2015). Power Hierarchy. Retrieved from: http://www.nationalpower.info/ladder-of-national-power-and-other-rankings/ Accessed September 10, 2015.

Innis, H. (2007, first published 1950). Empire and Communication. Toronto: Dundurn. International Institute for Strategic Studies (IIIS) (2015) The Military Balance. Volume 115, Issue 1.

International Monetary Fund (2014). Debt Relief Under the Heavily Indebted Poor Countries (HIPC) Initiative. Retrieved from https://www.imf.org/external/np/exr/facts/hipc.htm. Accessed October 21, 2014. 
International Monetary Fund (2015, April). World Economic Outlook Retrieved from. http://www.imf.org/external/pubs/ft/weo/2015/01/ Accessed October 28, 2015.

International Trade Administration (2014). AGOA Frequently Asked Questions. Retrieved from http://trade.gov/agoa/faq.asp\#top. Accessed October 21, 2014.

Is There an African Resource Curse? Hearing before the Subcommittee on Africa, Global Health, Global Human Rights, and International Organizations, House of Representatives, $113^{\text {th }}$ Cong. (2013) (Testimony of T. Alicante and C. Smith).

Jentleson, B. and Weber, S. (2008). America’s Hard Sell. Foreign Policy. November/December 2008. pp. 43-49.

Jervis, R. (1976). Perception and Misperception in International Politics. Princeton, NJ: Princeton University Press.

Jervis, R. (1991). Domino Beliefs and Strategic Behavior in Jervis, R. and Snyder, J. (eds). Dominoes and Bandwagons. New York: Oxford University Press.

Johnson, K. (2009). China's Strategic Culture: A Perspective for the United States. Carlisle, PA: Strategic Studies Institute, US Army War College, June 2009.

Jorgenson, H. and Strube, D. (2014). China, the G20 and Global Economic Governance. The Lowy Institute for International Policy.

Joselow, G. (2013, July 1). Obama Arrives in Tanzania with Trade in Mind. Voice of America.

Kagwanja, P. (2015, July 25). China’s Influence Engenders America’s Strategy in Africa. The Nation (Nairobi).

Kang, D. (2003). Getting Asia Wrong: The Need for New Analytical Frameworks. International Security, Spring 2003, 4, pp. 57-85.

Kang, D. (2007). China Rising: Peace, Power and Order in East Asia. New York, NY: Columbia University Press.

Karabell, Z. (2014, March 11). The 'Made in China' Fallacy. Slate Magazine. Retrieved from http://www.slate.com/articles/business/the_edgy_optimist/2014/03/u_s_china_trade _deficit_it_s_not_what_you_think_it_is.html Accessed September 10, 2015.

Katzenstein, P. (1996) (ed) The Culture of National Security: Norms and Identity in World Politics. New York, NY: Columbia University Press.

Keck, K. (2013, 7 Jan) Destined to fail: China’s soft power push. The Diplomat. 
Kegley, C. and Raymond, G. (1994). A Multipolar Peace? Great Power Politics in the Twenty-First Century. New York, NY: St. Martin’s Press.

Keim, C. (2014). Mistaking Africa: Curiosities and Inventions of the American Mind. Boulder, CO: Westview Press.

Keohane, R. (1984). After Hegemony: Cooperation and Discord in the World Political Economy. Princeton, NJ: Princeton University Press.

Keohane, R. and Nye, J. (2001). Power and Interdependence. New York, NY: Longman.

Kennedy, P. (1987). The Rise and Fall of Great Powers: Economic Change and Military Conflict from 1500 to 2000. New York: Random House.

Kerry, J. (2014, May). Africa is on the Rise, and We Need to Help Make Sure It Continues. DipNote. The U.S. Department of State.

Kerry, J. (2014, May 1). Remarks at the U.S.-African Union High-Level Dialogue. The U.S. Department of State.

Kerry, J. (2014, December 16). A Celebration of Excellence in U.S.-Africa Business Relations at Corporate Council on Africa. The U.S. Department of State.

Kimenyi, M. (2013, July 8). Obama’s Africa Trip: Symbolism and Substance. The Brookings Institution.

Kirshner, J. (2012). The Tragedy of Offensive Realism: Classical Realism and The Rise of China. European Journal of International Relations, Vol.18 (1), pp.53-75.

Klare, M. (2008). Rising Powers, Shrinking Planet. New York, NY: Metropolitan Books.

Klare, M., \& Volman, D. (2006). America, China and the Scramble for Africa's Oil. Review of African Political Economy, 108, 297-309.

Koronowski, R. (2014). “The War in Afghanistan by the Numbers.” Retrieved from http://thinkprogress.org/world/2014/12/28/3607134/afghanistan-war-by-thenumbers/. Accessed October 5, 2015.

Krasner, S. (1983). (ed) International Regimes. Ithaca, NY: Cornell University Press.

Kufuor, J. (2008, February 20). President Bush Participates in Press Availability with President Kufuor of Ghana. The White House.

Kufuor, J. (2008, September 15). President Bush and President Kufuor of Ghana Exchange Toasts. The White House. 
Kurlantzick, J. (2007). Charm Offensive: How China's Soft Power Is Transforming the World. New Haven, CT: Yale University Press.

Lampton, D. (2001). Same Bed, Different Dreams: Managing U.S.-China Relations, 1989-2000. Los Angeles, CA: University of California Press.

Lampton, D. (2008). The Three Faces of Chinese Power: Might, Money, And Minds. Berkeley, CA: University of California Press.

Larson, D., Paul, T.V., and Wohlforth, W. (2014). Status and World Order in Larson, D., Paul, T.V., Wohlforth, W. (Eds). Status in World Politics. New York, NY: Cambridge University Press.

Larson, D. and Shevchenko, A. (2014). Managing Rising Powers: The Role of Status Concerns in Larson, D., Paul, T.V., Wohlforth, W. (Eds). Status in World Politics. New York: Cambridge University Press.

Layne, C. (2012, April 25). The End of Pax Americana: How Western Decline Became Inevitable. The Atlantic.

Lebow, N. and Valentino, B. (2009). Lost in Transition: A Critical Analysis of Power Transition Theory. International Relations, Vol. 23(3); 389-410.

Li, M. (2009). Soft Power: China’s Emerging Strategy in International Politics. Lanham, MD: Lexington Books.

Li, Z. (2004, September 27). U.N. General Assembly Speech, 59 ${ }^{\text {th }}$. The United Nations.

Li, Z. (2005, September 19). U.N. General Assembly Speech, 60 ${ }^{\text {th }}$. The United Nations.

Li, Z. (2006, September 22). U.N. General Assembly Speech, 61 ${ }^{\text {st }}$. The United Nations.

Liang, W. (2012). China's Soft Power in Africa: Is Economic Power Sufficient?” Asian Perspective. 36, p. 667-692.

Lieber, R. (2002). Foreign Policy and American Primacy. In R. Lieber (Ed.), Eagle Rules? Foreign Policy and American Primacy in The Twenty-First Century. Upper Saddle River, N.J.: Prentice Hall.

Lim, R. (2003). The Geopolitics of East Asia: The Search for Equilibrium London: Routledge.

Liska, G. (2003). Twilight of a Hegemony: The Late Career of Imperial America. Dallas, TX: University Press of America. 
Littlefield, E. (2014, September 5). One Big Continent, One Big Summit, Three Big Lessons. DipNote. The U.S. Department of State.

Liu, Z. (2015, July 27). Vying for Influence Dilutes Obama’s African Visit. Global Times.

Look, A. (2012, July 31). Clinton to Promote Economic Growth, Democracy on Africa Trip. Voice of America.

Look, A. (2012, August 1). Clinton: America Wants Sustainable Partnerships in Africa. Voice of America.

Look, A. (2012, August 5). Clinton Promotes U.S. Investment in Africa. Voice of America.

Look, A. (2012, August 10). Clinton Winds Down Africa Tour. Voice of America.

Mahnken, T. (2012, September 2). The Shifting U.S.-China Nuclear Balance. Foreign Policy.

Mahmoud, Y. (2010). Chinese Foreign Aid: The Tale of a Silent Enterprise in Sorenson, J. (Ed). Challenging The Aid Paradigm: Western Currents and Asian Alternatives. New York, NY: Palgrave Macmillan.

Manor, I. \& Segev, E. (2015). America’s Selfie: How the U.S. Portrays Itself on its Social Media Accounts in (Eds.) Corneliu Bjola and Marcus Holmes. Digital Diplomacy: Theory and Practice. New York: Routledge.

Marantis, D. (2012, June 13). Briefing on U.S. Trade and Investment Policies in Africa and the Upcoming AGOA Forum.

Matthews, J. (1996). Current Gains and Future Outcomes: When Cumulative Relative Gains Matter. International Security, 21.1, Summer 1996, p. 112.

Mayer, R. (2002). Artificial Africas: Colonial Images in the Times of Globalization. Hanover: University Press of New England.

McCormick, T. (1990). World Systems. The Journal of American History, Vol. 77, No. 1, pp. 125-132.

McGreal, C. (2014, August 3). Obama Woos African Leaders to Counter Growing Chinese Influence. The Guardian.

Mearsheimer, J. (1994/5). False Promise of International Institutions. International Security 19 (Winter): 9-12. 
Mearsheimer, J. (2014). The Tragedy of Great Power Politics. New York, NY: W.W. Norton.

Melissen, J. (2005). The New Public Diplomacy: Between Theory and Practice in Melissen, J. (Ed) The New Public Diplomacy: Soft Power in International Relations. New York, NY: Palgrave MacMillan.

Mengara, D. (2001) (ed) Images of Africa: Stereotypes and Realities. Trenton, NJ: Africa World Press.

Meredith, R. (2007). The Elephant and The Dragon: The Rise of India and China and What It Means for All of Us. New York, NY: W.W. Norton \& Co.

Millennium Challenge Corporation (2014). Selection Criteria. Retrieved from http://www.mcc.gov/pages/selection. Accessed October 22, 2014.

Modelski, G. (1987). Long Cycles in World Politics. Seattle: University of Washington Press.

Morgensen, K. (2015). International Trust and Public Diplomacy. The International Communication Gazette. Vol. 77(4), pp. 315-336.

Morrison, J. and Cooke, J. (2001). Preview of Major Findings in Morrison, J. And Cooke, J. (Eds). Africa Policy in The Clinton Years: Critical Choices for The Bush Administration. Washington, DC: CSIS Press.

Morrison, J. and Cooke, J. (2009). A Smarter U.S. Approach to Africa in Morrison, J. and Cooke, J. (eds). U.S. Africa Policy Beyond the Bush Years: Critical Challenges for the Obama Administration. Washington, DC: CSIS Press.

Morrison, W. (2015). China’s Economic Rise: History, Trends, Challenges, and Implications for the United States. Congressional Research Service.

Naidoo, N. (2015, February 12). Kenya Trade to Benefit Further from Relationship with China. CNBC Africa.

Nation Ranking (2011). 2011 National Power Index. Retrieved from https://nationranking.wordpress.com/2011/03/06/2011-npi/ Accessed September 10, 2015.

Natsios, A. (2005, September 14). U.N. General Assembly, 60 ${ }^{\text {th }}, 3^{\text {rd }}$ Plenary. The United Nations.

Ndaba, V. (2015, September 2). Is 2015 the Beginning of the End for Africa's China-led Boom? Yahoo News. 
New Beginnings: Foreign Policy Priorities in the Obama Administration: Hearing before the Committee on Foreign Affairs, House of Representatives, $111^{\text {th }}$ Cong. (2009) (Testimony of H. Clinton).

Nigeria's Struggle with Corruption: Hearing Before the Subcommittee on Africa, Global Human Rights and International Operations, House of Representatives, $109^{\text {th }}$ Cong. (2006) (Testimony of G. Ayittey and D. Goldwyn).

Nijraini, J. (2014, December). AGOA: The U.S.-Africa Trade Dilemma. Africa Renewal.

Norrlof, C. (2013). America's Global Advantage: U.S. Hegemony and International Cooperation. New York, NY: Cambridge University Press.

Nye, Jr., J. (1990). Bound to Lead: The Changing Nature of American Power. New York, NY: Basic Books.

Nye, Jr., J. (2004). Soft Power: The Means to Success in World Politics. New York, NY: PublicAffairs.

Nye, Jr., J. (2008). Public Diplomacy and Soft Power. ANNALS of the American Academy of Political and Social Science, 616, pp. 94-109.

Obama, B. (2009, July 7). Interview of the President by AllAfrica.Com. The White House.

Obama, B. (2009, July 11). Remarks by President Obama and President Mills of Ghana After Bilateral Meeting. The White House.

Obama, B. (2009, July 11). Remarks by the President to the Ghanaian Parliament. The White House.

Obama, B. (2009, August 5). President Barack Obama’s Video Message to the AGOA Forum. The White House.

Obama, B. (2009, September 23). U.N. General Assembly, $64^{\text {th }}, 3^{\text {rd }}$ Plenary. The United Nations.

Obama, B. (2010, August 23). Remarks by the President at Town Hall with Young African Leaders. The White House.

Obama, B. (2010, September 23). U.N. General Assembly, 65 ${ }^{\text {th }}, 11^{\text {th }}$ Plenary. The United Nations.

Obama, B. (2011, January 19). Press Conference with President Obama and President Hu of the People's Republic of China. The White House. 
Obama, B. (2011, September 21). U.N. General Assembly $66^{\text {th }}, 11^{\text {th }}$ Plenary. The United Nations.

Obama, B. (2012, September 25). U.N. General Assembly $67^{\text {th }}, 6^{\text {th }}$ Plenary. The United Nations.

Obama, B. (2013, June 27). Remarks by President Obama and President Sall of the Republic of Senegal at Joint Press Conference. The White House.

Obama, B. (2013, June 29). Remarks by President Obama and President Zuma of South Africa at Joint Press Conference. The White House.

Obama, B. (2013, June 29). Remarks by President Obama at Young African Leaders Initiative Town Hall. The White House.

Obama, B. (2013, July 3). The World Is Watching What Decision You Make. The Star, Johannesburg, South Africa.

Obama, B. (2013, September 24). U.N. General Assembly, $68^{\text {th }}$. The United Nations.

Obama, B. (2014, May 28). Remarks by the President at the U.S. Military Academy Commencement. The White House.

Obama, B. (2014, August 2). An Interview with the President. The Economist.

Obama, B. (2014, September 24). U.N. General Assembly, 69 ${ }^{\text {th }}$. The United Nations.

Obama, B. (2015, July 28). Remarks by President Obama to the People of Africa. The White House.

OECD (2014). Statistics On Resource Flows to Developing Countries. Retrieved from http://www.oecd.org/dac/stats/statisticsonresourceflowstodevelopingcountries.htm. Accessed October 22, 2014.

Office of the Press Secretary. (2001, July 22). Accomplishments of G-7/8 Summit in Genoa, Italy. The White House.

Office of the Press Secretary. (2001, October 29). U.S.-Africa Strengthen CounterTerrorism and Economic Ties. The White House.

Office of the Press Secretary. (2002, December 10). Joint Statement by the United States of America, the Republic of Kenya, and Ethiopia. The White House.

Office of the U.S. Trade Representative. (2014). Africa Growth and Opportunity Act (AGOA). Retrieved from http://www.ustr.gov/trade-topics/trade- 
development/preference-programs/african-growth-and-opportunity-act-agoa. Accessed October 21, 2014.

Office of the U.S. Trade Representative. (2014). Africa. Retrieved from http://www.ustr.gov/countries-regions/africa. Accessed October 22, 2014.

Office of the U.S. Trade Representative (2014). U.S.-China Trade Facts. Retrieved from https://ustr.gov/countries-regions/china-mongolia-taiwan/peoples-republic-china Accessed September 10, 2015.

Office of the U.S. Trade Representative (2015). Sudan. Retrieved from https://ustr.gov/countries-regions/africa/east-africa/sudan Accessed October 29, 2015.

Ojonugwa, U. (2015, May 20). Nigeria Economy: How China and USA Battle for Relevance. Leadership.

Onea, T. (2014). Between Dominance and Decline: Status Anxiety and Great Power Rivalry. Review of International Studies, 40, pp. 125-152.

Organski, A. and Kugler, J. (1980). The War Ledger. Chicago: Univ. of Chicago Press.

Overholt, W. (2008). Asia, America and the Transformation of Geopolitics. New York, NY: Cambridge University Press.

Oye, K. (1986) (ed) Cooperation Under Anarchy. Princeton, NJ: Princeton University Press.

Page, B. and Shapiro, R. (1983) Effects of Public Opinion on Policy the American Political Science Review, Vol. 77, No. 1 (March 1983), pp. 175-190.

Pahlavi, P. (2007). Evaluating Public Diplomacy Programmes. Hague Journal of Diplomacy, 2, pp. 255-281.

Pamment, J. (2013). New Public Diplomacy in the $21^{\text {st }}$ Century: Evaluating Policy and Practice. Oxford: Routledge.

Parmar, I., Miller, L., Ledwidge, M. (2014) (eds) Obama and the World: New Directions in U.S. Foreign Policy. New York, NY: Routledge.

Paris Club. (2014) Retrieved from. http://www.clubdeparis.org/en/. Accessed October 22, 2014. 
Paul, T.V. and Shankar, M. (2014). Status Accommodation Through Institutional Means: India's Rise and The Global Order in Larson, D., Paul, T.V., Wohlforth, W. (Eds). Status in World Politics. New York: Cambridge University Press.

Perino, D. (2008, February 19). Press Gaggle by Dana Perino. The White House.

Pew Research Center (2013, December 3). Public Sees U.S. Power Declining as Support for Global Engagement Slips. Retrieved from http://www.peoplepress.org/2013/12/03/public-sees-u-s-power-declining-as-support-for-globalengagement-slips/ Accessed October 20, 2015.

Pew Research Center (2015, September 9). Americans’ Concerns About China: Economics, Cyber attacks, Human Rights Top the List. Retrieved from http://www.pewglobal.org/2015/09/09/americans-concerns-about-china-economicscyberattacks-human-rights-top-the-list/ Accessed October 20, 2015.

Pham, J. (2006). China’s African Strategy and its Implications for U.S. Interests. American Foreign Policy Interests, 28: 239-253.

Pham, J. (2012). Boko Haram’s Evolving Threat. Africa Security Brief, no. 20, April 2012.

Pouliot, V. (2014). Setting Status in Stone: The Negotiation of International Institutional Privileges in Larson, D., Paul, T.V., Wohlforth, W. (Eds). Status in World Politics. New York: Cambridge University Press.

Powell, A. (2013, June 25). Obama Means Business During Africa Trip. Voice of America.

Powell, C. (2001, February 4). Interview on ABC’s This Week. The U.S. State Department.

Powell, C. (2001, April 23). Interview on the Lehrer News Hour. The U.S. State Department.

Powell, C. (2001, May 14). Interview on CNN. The U.S. State Department.

Powell, C. (2001, May 22). Remarks to the Press Aboard Aircraft En Route to Bamako, Mali. The U.S. State Department.

Powell, C. (2001, May 23). Press Availability with Malian Foreign Minister Madibo Sidibe Following Meeting with President Konare. The U.S. State Department.

Powell, C. (2001, May 25). Press Availability with South African Foreign Minister Zuma. The U.S. State Department. 
Powell, C. (2001, May 25). Remarks at the University of Witwatersrand. The U.S. State Department.

Powell, C. (2001, May 26). Remarks with Kenyan President Daniel Arap Moi following their Meeting. The U.S. State Department.

Powell, C. (2001, May 27). Remarks to the Press on Trip to Africa and North Atlantic Council Meeting. The U.S. State Department.

Powell, C. (2001, October 20). Introduction of President George W. Bush to the African Growth and Opportunity Act Forum. The U.S. State Department.

Powell, C. (2002, November 7). Remarks at African Growth and Opportunity Act Business Roundtable. The U.S. State Department.

Powell, C. (2003, March 29). Interview by the New York Times. The U.S. State Department.

Powell, C. (2003, June 27). Keynote Address to Corporate Council on Africa's 2003 U.S.-Africa Business Summit. The U.S. State Department.

Powell, C. (2003, July 10). Interview by the South African Broadcasting Corporation. The U.S. State Department.

Powell, C. (2004, January 10). A Strategy of Partnerships. Foreign Affairs.

January/February issue.

Powell, C. (2004, February 6). Remarks to the International Reconstruction Conference on Liberia. The U.S. State Department.

Powell, C. (2004, September 16). Interview with the Washington Times Editorial Board. The U.S. State Department.

Powell, C. (2004, October 14). Interview by Clarence Page of the Chicago Tribune. The U.S. State Department.

Powell, C. (2004, October 18). Interview with the USA Today Editorial Board. The U.S. State Department.

Powell, C. (2005, January 12). No Country Left Behind. The U.S. State Department.

Powell, R. (1991) Absolute and Relative Gains in International Relations Theory

American Political Science Review. Vol. 85, No. 4 (Dec. 1991), pp. 1303-1320. 
Powermetrics Information Network (2014). Retrieved

from http://powermetrics.bplaced.net/formulas/ Accessed September 10, 2015.

$\mathrm{Pu}, \mathrm{X}$. and Schweller, R. (2014). Status Signaling, Multiple Audiences, And China’s Blue-Water Naval Ambition in Larson, D., Paul, T.V., Wohlforth, W. (Eds). Status in World Politics. New York, NY: Cambridge University Press.

Ramo, J. (2004). The Beijing Consensus. London: The Foreign Policy Centre.

Rangel, C. (2003). Africa: Growth and Opportunity in Bergner, J. (Ed). The Next American Century: Essays in Honor of Richard G. Lugar. Lanham, MD: Rowman \& Littlefield Publishers, Inc.

Rapkin, D. \& Thompson, W. (2013). Transition Scenarios: China and The United States in The Twenty-First Century. Chicago, IL: University of Chicago Press.

Randle, J. (2013, June 25). Obama to Discuss Trade, Investment in Africa. Voice of America.

Removing Obstacles for African Entrepreneurs: Hearing before the Subcommittee on Africa, Global Human Rights and International Operations, House of Representatives, $109^{\text {th }}$ Cong. (2006) (Testimony by C. Smith).

Resource Curse or Blessing? Africa's Management of its Extractive Industries: Hearing before the Subcommittee on African Affairs, Senate, $110^{\text {th }}$ Cong. (2008) (Testimony by D. Goldwyn and S. Gallogly).

Reuters (2015). China Will Not Follow 'Western Colonists’ in Africa: Chinese Foreign Minister. Retrieved from http://www.reuters.com/article/2015/01/12/us-china-africaidUSKBN0KL09720150112 Accessed October 20, 2015.

Rheault, M. and McCarthy, J. (2015). U.S. Still Leads China in Leadership Approval in Africa. Gallup. Retrieved from http://www.gallup.com/poll/184481/still-leads-chinaleadership-approvalafrica.aspx?g_source=us\%20approval\&g_medium=search\&g_campaign=tiles. Accessed October 28, 2015.

Rhodes, B. (2014, August 1). On-the-Record Conference Call on the U.S.-Africa Leaders Summit. The White House.

Rhodes, B. (2015, July 26). Press Briefing by Press Secretary Josh Earnest and Deputy National Security Advisor Ben Rhodes. The White House.

Rice, C. (2003, July 3). Dr. Condoleezza Rice Discusses the President’s Trip to Africa. The U.S. Department of State. 
Rice, C. (2005, January 18). Opening Remarks by Secretary-of-State-Designate Dr. Condoleezza Rice. Senate Foreign Relations Committee.

Rice, C. (2005, March 14). Announcement of Karen P. Hughes as Under Secretary of State for Public Diplomacy and Public Affairs and Dina Powell as Assistant Secretary of State for Educational and Cultural Affairs. The U.S. Department of State.

Rice, C. (2005, July 10). Press Availability in Beijing. The U.S. Department of State.

Rice, C. (2005, July 20). Remarks at the AGOA Forum in Dakar, Senegal. The U.S. Department of State.

Rice, C. (2005, July 20). Press Availability with Senegalese Foreign Minister Cheikh Tidiane Gadio. The U.S. Department of State.

Rice, C. (2005, July 25). Interview with Adam Garfinkle and Dan Kennelly of the American Interest. The U.S. Department of State.

Rice, C. (2006, February 15). Realizing the Goals of Transformational Diplomacy. The U.S. Department of State.

Rice, C. (2006, March 31). Remarks at BBC Today - Chatham House Lecture. The U.S. Department of State.

Rice, C. (2006, April 13). Interview on Cox Television with Scott MacFarlane. The U.S. Department of State.

Rice, C. (2006, April 19). Opening Remarks and Q \& A Session at Chicago Council on Foreign Relations. The U.S. Department of State.

Rice, C. (2006, June 6). Remarks at the African Growth and Opportunity Act Forum 2006. The U.S. Department of State.

Rice, C. (2006, September 27). Address to the Africa Society of the National Summit on Africa. The U.S. Department of State.

Rice, C. (2006, November 6). Inaugural Meeting of Members of the Advisory Committee on Democracy Promotion. The U.S. Department of State.

Rice, C. (2006, December 21). Interview by Anne Gearan of the Associated Press. The U.S. Department of State.

Rice, C. (2007, February 8). Remarks on Transformational Diplomacy. The U.S. Department of State. 
Rice, C. (2007, April 18). Remarks at the InterAction 2007 Annual Forum. The U.S. Department of State.

Rice, C. (2007, July 23). Lesotho Prime Minister Pakalitha Mosisilli and MCC Chief Executive Officer John Danilovich at the Millennium Challenge Corporation's Compact Signing Ceremony with the Kingdom of Lesotho. The U.S. Department of State.

Rice, C. (2007, December 20). Interview with Josef Joffe of Die Zeit Newspaper. The U.S. Department of State.

Rice, C. (2008, January 23). Keynote Address at the Annual Meeting of the World Economic Forum. The U.S. Department of State.

Rice, C. (2008, July 1). Interview with Judy Woodruff of Bloomberg TV. The U.S. Department of State.

Rice, C. (2008, July 15). Remarks at the African Growth and Opportunity Act Forum. The U.S. Department of State.

Rice, C. (2008, September 5). Interview with Erin Burnett of CNBC. The U.S. Department of State.

Rice, C. (2008, September 23). Interview with Steve Leisman of CNBC. The U.S. Department of State.

Rice, C. (2008, December 9). Interview on CBS News Radio with Dan Raviv and Charles Wolfson. The U.S. Department of State.

Rice, C. (2008, December 9). Interview with Michele Kelemen of NPR. The U.S. Department of State.

Rice, C. (2008, December 17). Remarks from Daughters and Sons Meeting at the Council on Foreign Relations. The U.S. Department of State.

Rice, C. (2008, December 18). Interview with Sandra Sobieraj Westfall of People Magazine. The U.S. Department of State.

Rice, C. (2008, December 21). Interview on NBC’s Meet the Press with David Gregory. The U.S. Department of State.

Rice, C. (2009, January 13). Interview with Mike Schneider of Bloomberg TV. The U.S. Department of State.

Rice, C. (2009, January 14). Interview with April Ryan of American Urban Radio. The 


\section{U.S. Department of State.}

Riordan, S. (2003). The New Diplomacy. Cambridge, UK: Polity.

Rising Oil Prices, Declining National Security? Hearing before the Committee on Foreign Affairs, House of Representatives, $110^{\text {th }}$ Cong. (2008) (Testimony of H. Berman).

Robinson, D. (2013, June 19). Obama Africa Trip Is Effort to Re-Engage with The Continent. Voice of America.

Rosecrance, R. and Gu, G. (2009). Foreword: A U.S.-Chinese Perspective in Rosecrance, R. And Gu, G. (Eds) Power and Restraint: A Shared Vision for The U.S.-China Relationship. New York: Public Affairs.

Ross, C. (2002). Public Diplomacy Comes of Age. The Washington Quarterly 25, no. 2: 82.

Ross, R. (2009). Chinese Security Policy: Structure, Power and Politics. London: Routledge.

Rothchild, D. (2002). The United States and Africa: Power with Limited Influence. In Lieber, R. (Ed.), Eagle Rules? Foreign Policy and American Primacy in The TwentyFirst Century. Upper Saddle River, N.J.: Prentice Hall.

Rottinghaus, B. (2006) Rethinking Presidential Responsiveness: The Public Presidency and Rhetorical Congruency, 1953-2001. The Journal of Politics, Vol. 68, Issue 3, pp. 720-732.

Rousseau, D. (2002). Motivations for Choice: The Salience of Relative Gains in International Politics. The Journal of Conflict Resolution. 46, 3. June, 2002.

Rowden, R. (2013, January 4). The Myth of Africa’s Rise. Foreign Policy.

Rozell, M. and Whitney, G. (2009). Testing the Limits: George W. Bush and the Imperial Presidency. Lanham, MD: Rowman \& Littlefield.

Saldana, Johnny. (2011). Fundamentals of Qualitative Research. Oxford: Oxford University Press.

Sammis, J. (2011, October 3). U.N. General Assembly 66 ${ }^{\text {th }}$, Second Committee, Third Meeting. The United Nations.

Santora, M. (2015, July 24). Obama to Push U.S. Trade in Kenya as China’s Role Grows. New York Times. 
Schacke, K. (2009). Managing American Hegemony: Essays on Power in a Time of Dominance. Stanford, CA: Hoover Institution Press.

Schiller, H. (1992, first published 1969). Mass Communications and American Empire, second edition, updated. Boulder, CO: Westview Press.

Schraeder, P. (1994). United States Foreign Policy Toward Africa: Incrementalism, Crisis and Change. U.K.: Cambridge University Press.

Sen, A. (2012, August 1). U.S. Wants to Mend Ties with Sudan. The Washington Times. Senior Official (2012, August 4). Background Briefing on Secretary Clinton's Travel to Africa. The White House.

Sergie, A. and Johnson, T. (2015, March 5). Boko Haram. The Council on Foreign Relations.

Shadbolt, P. (2011). China, Hip-Hop and the New Sudan. CNN. Retrieved from http://www.cnn.com/2011/WORLD/africa/02/02/sudan.jal/ Accessed October 29, 2015.

Shambaugh, D. (2003). Modernizing China's Military: Progress, Problems, and Prospects. Berkeley, CA: University of Los Angeles Press.

Shambaugh, D. (2013). Conceptualizing The U.S.-China Relationship in Shambaugh, D. (Ed). Tangled Titans: The United States and China. Lanham, MD: Rowman \& Littlefield Publishers, Inc.

Shambaugh, D. and Murphy, D. (2013). U.S.-China Interactions in The Middle East, Africa, Europe, And Latin America in Shambaugh, D. (Ed). Tangled Titans: The United States and China. Lanham, MD: Rowman \& Littlefield Publishers, Inc.

Shinn, D. (2014, June 11). Ethiopia and China: How Two Former Empires Connected. International Policy Digest.

Shinn, D. (2014, September 10). Forum on China-Africa Cooperation vs. U.S.-Africa Summit. China-U.S. Focus.

Shirk, S. (2007). China: Fragile Superpower. Oxford: Oxford University Press, 2007.

Sify Sports (2008, August 25). China Celebrates ‘Huge Prestige Bonanza’ of Olympics. Retrieved from http://www.sify.com/sports/china-celebrates-huge-prestige-bonanza-ofolympics-news-olympics-jegxqGbaicgsi.html Accessed October 20, 2015. 
Singer, J., Bremer, S., and Stuckey, J. (1972). Capability Distribution, Uncertainty, and Major Power War, 1820-1965. in Bruce Russett (ed) Peace, War, and Numbers, Beverly Hills: Sage, 19-48.

Snidal, D. (1985). The Limits of Hegemonic Stability Theory. International Organization. 39, pp. 579-614.

Snidal, D. (1991). Relative Gains and the Pattern of International Cooperation. The American Political Science Review. Sep. 1991; 85, 3.

Sputnik International (2014, August 5). U.S. Lags Behind Europe, China in Africa. Retrieved from http://m.sputniknews.com/analysis/20140805/191757336/OPINION-USlags-behind-Europe-China-in-Africa--expert.html Accessed October 20, 2015.

Starr, B. and Botelho, G. (2013, November 26). Official: U.S. B-52s Flew Over China's Controversial New Air Defense Zone. CNN.

Stockholm International Peace Research Institute (2015). SIPRI Military Expenditure Database. Retrieved from http://www.sipri.org/research/armaments/milex/milex_database Accessed September 10, 2015.

Sutter, R. (2013). U.S.-Chinese Relations: Perilous Past, Pragmatic Present. 2nd ed. Lanham, MD: Rowman \& Littlefield Publishers, Inc.

Swaine, M. and Tellis, A. (2000). Interpreting China's Grand Strategy: Past, Present and Future. Santa Monica, CA: RAND.

Swan, J. (2007, February 9). Speech at Columbia University.

Taliaferro, J. (2004). Balancing Risks: Great Power Intervention in The Periphery. Ithaca, NY: Cornell University Press.

Taylor, A. (2013, May 27). Why the Beijing Olympics Were a Huge Mistake for China. Business Insider.

Taylor, I. (2004). The 'All-Weather Friend'? Sino-African Interaction in The TwentyFirst Century in Taylor, I. And Williams, P. (Eds). Africa in International Politics: External Involvement On the Continent. London: Routledge.

Tellis, A., Bially, J., Layne, C., McPherson, M. (2000). Measuring National Power in the Postindustrial Age. RAND Corporation.

The African Growth and Opportunity Act: Hearing before the Foreign Relations Committee, Senate, $108^{\text {th }}$ Cong. (2003) (Testimony by F. Liser). 
The African Growth and Opportunity Act: A Five-Year Assessment: Hearing before the Subcommittee on Africa, Global Human Rights and International Operations, House of Representatives, $109^{\text {th }}$ Cong. (2005) (Testimony by G. Meeks and D. Payne).

The African Growth and Opportunity Act: Ensuring Success: Hearing before the Subcommittee on Terrorism, Nonproliferation, and Trade, the Subcommittee on Africa, Global Health and Human Rights, and the Committee on Foreign Affairs, House of Representatives, $112^{\text {th }}$ Cong. (2012) (Testimony of A. Carroll and S. Hayes).

The Economist (2014, August 2). The New Great Disruption.

The Mail \& Guardian Africa (2015, March 15). Eight Myths and Facts About the Turbulent U.S.-Zim Relationship: Why Mugabe Is Eating Cake. Retrieved from http://mgafrica.com/article/2015-03-06-the-facts-and-myths-about-the-uszimbabwe-ties Accessed October 13, 2015.

The Mail \& Guardian Africa (2015, September 19). What Crisis? 16 of China's Biggest Projects in Africa - It's All Billion Dollar Territory In Here. http://mgafrica.com/article/2015-09-18-multi-billion-dollar-deals-chinas-27biggest-active-projects-in-africa. Accessed October 13, 2015.

The Millennium Challenge Corporation in Africa: Promise Versus Progress: Hearing before the Subcommittee on Africa and Global Health, House of Representatives, $110^{\text {th }}$ Cong. (2007) (Testimony of A. Carroll).

The United States President's Emergency Plan for AIDS Relief (2015). http://www.pepfar.gov/ Accessed October 15, 2015.

Thomas-Greenfield, L. (2014, May 14). LiveAtState: U.S. Commitment to Sub-Saharan Africa. The U.S. Department of State.

Thomas-Greenfield, L. (2014, July 31). Remarks at the Atlantic Council. The U.S. Department of State.

Thomas-Greenfield, L. (2015, August 26). AGOA 2015: Moving to Sustainable U.S.Africa Trade and Investment Partnership. Dipnote. The U.S. Department of State.

Thucydides as translated by Sir Richard Livingstone (1960). The History of the Peloponnesian War. New York, NY: Oxford University Press.

Tiezzi, S. (2015, January 29). China’s ‘Maritime Silk Road’: Don’t Forget Africa. The Diplomat.

Transparency International (2015). Corruption Perceptions Index. Retrieved from http://www.transparency.org/research/cpi/overview Accessed October 15, 2015. 
Tuch, H. (1990). Communicating with The World: U.S. Public Diplomacy Overseas. New York, NY: St. Martin’s Press.

Tucker, N. (2013). The Evolution of U.S.-China Relations in Shambaugh, D. (Ed). Tangled Titans: The United States and China. Lanham, MD: Rowman \& Littlefield Publishers, Inc.

Tucker, S. (2008). Encyclopedia of the Cold War: A Political, Social, and Military History. Santa Barbara, Calif: ABC-CLIO.

Tunstall, J. (1977). The Media are American. London: Constable.

Tyler, S. \& Bogdan, R. (1984). Introduction to Qualitative Research Methods: The Search for Meanings. Second edition. New York: John Wiley \& Sons.

U.N. Comtrade (2015). http://comtrade.U.N..org/data/ Accessed October 29, 2015.

Union of Concerned Scientists (2011). China’s Nuclear Arsenal: No ‘Sprint to Parity’.

United Nations (2011). Economic Development in Africa. The United Nations Industrial Development Organization (UNIDO) and United Nations Conference on Trade and Development (UNCTAD).

University of Southern California Center for Public Diplomacy (2006). Center Overview. Los Angeles, CA.

U.S. Advisory Commission on Public Diplomacy (2014). 2014 Comprehensive Annual Report on Public Diplomacy and International Broadcasting: Focus on FY13 Budget Data. (Eds) Katherine Brown and Chris Hensman.

U.S. Advisory Commission on Public Diplomacy (2015). 2015 Comprehensive Annual Report on Public Diplomacy and International Broadcasting: Focus on FY14 Budget Data. (Eds) Katherine Brown and Chris Hensman.

U.S. Africa Command (2014). What We Do. Retrieved from

http://www.africom.mil/what-we-do. Accessed October 21, 2014.

U.S.-Africa Trade Relations: Creating a Platform for Economic Growth: Joint Hearing before the Subcommittee on Commerce, Trade and Consumer Protection, the Committee on Energy and Commerce, the Subcommittee on Africa and Global Health and the Committee on Foreign Affairs, House of Representatives, $111^{\text {th }}$ Cong. (2009) (Testimony of L. Cook, F. Liser, H. Vineyard). 
U.S. Assistance to Africa: A Call for Foreign Aid Reform: Hearing before the Subcommittee on Africa and Global Health, House of Representatives, $111^{\text {th }}$ Cong. (2009).

U.S. Census Bureau (2015). Trade in Goods with China. Retrieved from https://www.census.gov/foreign-trade/balance/c5700.html Accessed September 10, 2015.

U.S. Chamber of Commerce /Africa Business Initiative (2009). Inside the Boardroom: How Corporate America Really Views Africa. Retrieved from https://www.uschamber.com/sites/default/files/legacy/international/africa/files/abi ceo_suvey.pdf Accessed October 13, 2015.

U.S. Chamber of Commerce (2015, May 11). U.S. Chamber Launches National Ad Campaign Calling for Reauthorization of Ex-Im Bank. Retrieved from https://www.uschamber.com/press-release/us-chamber-launches-national-adcampaign-calling-reauthorization-ex-im-bank Accessed January 31, 2016.

U.S. Defense Security Cooperation Agency (2015). Excess Defense Articles (EDA). http://www.dsca.mil/programs/excess-defense-articles-eda Accessed October 15, 2015.

U.S. Department of Defense. (2001, September 30). Quadrennial Defense Review Report. U.S. Department of Defense. (2006, February 6). Quadrennial Defense Review Report. U.S. Department of Defense (2006). Annual Report to Congress: Military Power of the People's Republic of China. Office of the Secretary of Defense.

U.S. Department of Defense (2009). Annual Report to Congress: Military Power of the People's Republic of China. Office of the Secretary of Defense.

U.S. Department of Defense. (2010, February). Quadrennial Defense Review Report.

U.S. Department of Defense (2013). Annual Report to Congress: Military and Security Developments Involving the People's Republic of China. Office of the Secretary of Defense.

U.S. Department of Defense. (2014, March 4). Quadrennial Defense Review Report. U.S. Department of State (2005). African Global Competitiveness Initiative. Retrieved from http://2001-2009.state.gov/p/af/rls/fs/49817.htm. Accessed October 21, 2014.

U.S. Department of State (2012, June 19). YALI Q\&A. 
U.S. Department of State (2012, July 20). YALI Q\&A.

U.S. Department of State (2013). African Contingency and Operations Training and Assistance (ACOTA) Program. Retrieved from http://www.state.gov/r/pa/prs/ps/2013/02/203841.htm. Accessed October 21, 2014.

U.S. Department of State (2014). International Military Education and Training (IMET). Retrieved from http://www.state.gov/t/pm/65533.htm. Accessed October 22, 2014.

U.S. Department of State (2014). Under Secretary for Public Diplomacy and Public Affairs. Retrieved from http://www.state.gov/r/ Accessed December 10, 2014.

U.S. Department of State (2014, May 30). U.S. Relations with Sudan. Retrieved from http://www.state.gov/r/pa/ei/bgn/5424.htm Accessed October 29, 2015.

U.S. Department of State (2014, December 9). U.S. Relations with Nigeria. Retrieved from http://www.state.gov/r/pa/ei/bgn/2836.htm Accessed October 30, 2015.

U.S. Department of State (2014, October 30). YALI 2015 Q \& A with a 2014 Mandela Washington Fellow - Engaging Youth in the Democratic Process.

U.S. Department of State (2015). Budget and Planning, International Affairs Budget. Retrieved from http://www.state.gov/s/d/rm/c6112.htm Accessed October 21, 2015.

U.S. Department of State. (2015). Bureau of International Information Programs. Retrieved from http://www.state.gov/r/iip/. Accessed April 6, 2015.

U.S. Department of State (2015, October 6). U.S. Relations with Zimbabwe. Retrieved from http://www.state.gov/r/pa/ei/bgn/5479.htm Accessed October 29, 2015.

U.S. Department of State (2015). DipNote. Retrieved from http://blogs.state.gov/ Accessed November 2, 2015.

U.S. Export-Import Bank (2016). Africa, Sub-Saharan. Retrieved from http://www.exim.gov/about/special-initiatives-assistance/africa Accessed January 31, 2016.

U.S. Information Agency Alumni Association (2014). What Is Public Diplomacy? Washington, D.C. Retrieved from http://www.publicdiplomacy.org/1.htm. Accessed December 10, 2014.

van Ham, P. (2005). Power, Public Diplomacy and The Pax Americana in Melissen, J. (Ed) The New Public Diplomacy: Soft Power in International Relations. NY: Palgrave MacMillan. 
Voice of America (2010, December 8). WikiLeaks Revelations Could Have Serious Consequences for Africa.

Voice of America (2011, June 9). Clinton Says Africa Must Fight Corruption to Boost Trade.

Voice of America (2013, June 25). U.S.-China Rivalry Exemplified in Obama Visit to Tanzania.

Voice of America (2013, June 30). U.S.-China Competition Plays Out in Tanzania.

Volgy, T., Corbetta, R., Rhamey, J. (2011). The Two Clubs: Major Global Powers, Major Regional Powers and Status Considerations in International Politics. Paper presented at the annual meeting of the International Studies Association Annual Conference "Global Governance: Political Authority in Transition", Le Centre Sheraton Montreal Hotel, Montreal, Quebec, Canada.

Volgy, T., Corbetta, R., Rhamey, J., Baird, R., Grant, K. (2014). Status Considerations in International Politics and the Rise of Regional Powers in Larson, D., Paul, T.V., Wohlforth, W. (Eds). Status in World Politics. New York: Cambridge University Press.

Walker, J. (2008). China, U.S. and Africa: Competition or Cooperation? U.S. Army War College.

Wallerstein, I.M. (1974). The Modern World-System. New York: Academic Press

Walt, S. (1987). The Origins of Alliances. Ithaca, NY: Cornell University Press.

Waltz, K. (1979). Theory of International Politics. Reading, MA: Addison-Wesley.

Wang, D. (2010). China’s Trade Relations with the United States in Perspective.” Journal of Current Chinese Affairs. 39, 3, 165-210.

Wang, D. (2013). The United States and China: A History from the $18^{\text {th }}$ Century to the Present. Lanham, MD: Rowman \& Littlefield Publishers.

Wang, J. (2011). Soft Power in China: Public Diplomacy Through Communication. NY: Palgrave Macmillan.

Washington Times (2008, February 12). 4 Arrests in China Spy Cases.

Wen, J. (2008, September 24). U.N. General Assembly Speech, 63 ${ }^{\text {rd }}$. The United Nations.

Wen, J. (2010, September 23). U.N. General Assembly Speech, 65 ${ }^{\text {th }}$. The United Nations. 
Wendt, A. (1992) Anarchy Is What States Make of It: The Social Construction of Power Politics. International Organization, 46, 2(Spring), pp. 391-425.

Werner, S. (1997) In Search of Security: Relative Gains and Losses in Dyadic Relations. Journal of Peace Research, 34/3 (August), pp. 289-302.

Wertime, D. (2015, September 23). Unpacking Xi Jinping’s Pet Phrase for U.S.-China Ties. Foreign Policy.

Westad, O. A. (2005). The Global Cold War: Third World Interventions and The Making of Our Times. Cambridge: Cambridge University Press.

Wezeman, P., Wezeman, S. and Beraud-Sudreau, L. (2011). Arms Flows to Sub-Saharan Africa. Stockholm International Peace Research Institute.

Wezeman, P. (2015). SIPRI: ‘China’s Arms Trade with Africa at Times Questionable’. Retrieved from http://www.dw.com/en/sipri-chinas-arms-trade-with-africa-at-timesquestionable/a-18319346 Accessed October 13, 2015.

White, D. (2014). U.S. and Europe Fight Back as China's Influence Grows in Africa. The Financial Times.

White, H. (2009). Why War in Asia Remains Thinkable,’' Survival: Global Politics and Strategy, Dec. 2008-Jan. 2009, p. 6, pp. 85-103.

White House (2010). National Security Strategy. Washington, DC.

White House (2012). U.S. Strategy Toward Sub-Saharan Africa. Washington, DC.

White House (2013). President Obama’s 2013 Africa Trip. Retrieved

from https://www.whitehouse.gov/africa-trip-2013 Accessed October 21, 2015.

White House (2014). Fact Sheet on U.S. Support for Peacekeeping in Africa.

Washington, DC.

White House (2014). U.S.-Africa Leaders Summit. Retrieved

from https://www.whitehouse.gov/us-africa-leaders-summit Accessed October 21, 2015.

White House (2015). National Security Strategy. Washington, DC.

Wike, R. (2015, September 9). Americans’ Concerns About China: Economics, Cyber attacks, Human Rights Top the List. Pew Research Center. Retrieved from http://www.pewglobal.org/2015/09/09/americans-concerns-about-chinaeconomics-cyberattacks-human-rights-top-the-list/ Accessed October 28, 2015. 
WikiLeaks (2006, October 23). PRC/Africa: African Heads of State Heading to China En Masse for Beijing Summit of the Forum for China-Africa Cooperation (FOCAC).

WikiLeaks (2009, February 5). Two African Diplomats in Beijing Share Views on ChinaAfrica Relations.

WikiLeaks (2010, February 11). African Embassies Suspicious of U.S.-China Development Cooperation in Africa.

WikiLeaks (2010, February 23). Assistant Secretary Carson Meets Oil Companies in Lagos.

Williams, B. (2014). African Growth and Opportunity Act (AGOA): Background and Reauthorization. Washington, DC: Congressional Research Service.

Wilson, III, E. (2008). Hard Power, Soft Power, Smart Power. The Annals of the American Academy of Political and Social Science. 616.

Wingfield, B. (2015, December 1). U.S. Export-Import Bank. Bloomberg Quick Take. Retrieved from http://www.bloombergview.com/quicktake/u-s-export-import-bank. Accessed January 31, 2016.

Wlezien, C. and Soroka, S. (2007) Public Opinion and Public Policy in the Oxford Handbook of Canadian Politics.

Wohlforth, W. (2009). Unipolarity, Status Competition and Great Power War. World Politics, Vol. 61, No. 1, pp. 28-57.

Wohlforth, W. (2014). Status Dilemmas and Inter-state Conflict in Larson, D., Paul, T.V., Wohlforth, W. (Eds). Status in World Politics. New York, NY: Cambridge University Press.

Wolf, Jr., C. and Rosen, B. (2004). Public Diplomacy: How to Think About and Improve It. Santa Monica, CA: RAND Corporation.

Wolf, R. (2014). Rising Powers, Status Ambitions, And The Need to Reassure: What China Could Learn from Imperial Germany’s Failures. The Chinese Journal of International Politics. pp. 185-219.

World Bank (2015). Africa Overview. Retrieved from http://www.worldbank.org/en/region/afr/overview Accessed October 28, 2015.

World Bank (2015, October). Africa’s Pulse. Vol. 12. Retrieved from http://wwwwds.worldbank.org/external/default/WDSContentServer/WDSP/IB/2015/10/05/090224b0 
831245a9/3_0/Rendered/PDF/Africa0s0pulse00October020150.pdf Accessed October 28, 2015.

World Public Library (2015). Omar Hasan Ahmad Al-Bashir. Retrieved from http://www.worldlibrary.org/Article.aspx?Title=Omar_Hasan_Ahmad_al-Bashir Accessed October 29, 2015.

World Public Opinion (2010). American Public Vastly Overestimates Amount of U.S. Foreign Aid. Retrieved from http://www.worldpublicopinion.org/pipa/articles/brunitedstatescanadara/670.php Accessed October 15, 2015.

World Trade Organization (2015). Disputes by Country/Territory. Retrieved from https://www.wto.org/english/tratop_e/dispu_e/dispu_by_country_e.htm Accessed October 6, 2015.

Wu, X. (2013). Chinese Visions of the Future of U.S.-China Relations. In Shambaugh, D. (Ed). Tangled Titans: The United States and China. Lanham, MD: Rowman \& Littlefield Publishers, Inc.

Xi, J. (2015, September 28). U.N. General Assembly Speech, $70^{\text {th }}$. The United Nations.

Xin, X. How the Market is Changing China's News: The Case of Xinhua News Agency. New York: Lexington.

Xinhua News (2015, July 27). Despite Fanfare, U.S. Aid Programs for Africa Fail to Make Big Difference. Retrieved from http://news.xinhuanet.com/english/201507/27/c_134451370.htm Accessed October 20, 2015.

Yang, J. (2009). Avoiding Crisis Between the Two Great Powers. In R. Roserance and G. Guoliang (Eds.), Power and Restraint: A Shared Vision for The U.S.-China Relationship. New York: Public Affairs.

Yang, J. (2011, September 28). U.N. General Assembly Speech, 66 ${ }^{\text {th }}$. The United Nations.

Yun, S. (2015, October 1). China-Africa Think Tanks Forum: China Broadens Soft Power Campaigns in Africa. The Brookings Institution.

Yun, S. and Rettig, M. (2014). American and Chinese Trade with Africa: Rhetoric vs. Reality. The Hill.

Zaharna, R. (2007, February 29). The Network Communication Paradigm: Creating Soft Power in A Global Communication Era. Paper Presented at The Annual Conference of ISA, Chicago, IL. 
Zhao, S. (2008). The Transformation of U.S.-China Relations in Zhao, S. (Ed). China and The United States: Cooperation and Competition in Northeast Asia. New York: Palgrave Macmillan.

Zhao, S. (2011, April 13). The Geopolitics of China-African Oil. China Briefing.

Zhong, X. \& Lu, J. (2013). Public Diplomacy Meets Social Media: A Study of the U.S. Embassy’s Blogs and Micro-Blogs. Public Relations Review, 39, pp. 542-548.

Zoellick, R. (2005, September 21). Wither China: From Membership to Responsibility? Remarks to the National Committee on U.S.-China Relations.

Zuma, J. (2013, June 29). Remarks by President Obama and President Zuma of South Africa at Joint Press Conference.

Zweig, D. and Bi, J. (2005). China’s Global Hunt for Energy in Foreign Affairs, September/October. 


\section{$\underline{\text { APPENDIX }}$}

\section{DATA COLLECTED}

- Official government documents and publications

- Speeches by government officials

- Memos and minutes of meetings

- Articles and papers written by government officials

- Official government statements

- Material quoted from government officials located in other sources (e.g., books)

- Government websites

- Congressional hearings and reports

- Freedom of Information Act documents relating specifically to the U.S.-Africa Leaders Summit

- United Nations Security Council meeting transcripts, year 2000 - 2014

- United Nations General Assembly meeting reports, year 2000 - 2014

- Official government social media sites, including blogs, Facebook and Twitter

- Surveys of State Department and other officials.

- Forum on China-Africa Cooperation (FOCAC) documents 


\section{$\underline{\text { PROCEDURES }}$}

- $\quad$ Step \#1: Collected and performed analysis on selected documentation, as described in the Data section above. NVivo software used to code themes relating to research questions.

- $\quad$ Step \#2: Assembled and analyzed results before beginning survey process.

- Step \#3: Selected key government officials to take part in the survey process, particularly from USAID, the State Department and the Executive Office of the President.

- $\quad$ Step \#4: Reached out to officials to request survey participation, which took place via Survey Monkey. See list of questions at the end of the chapter.

- $\quad$ Step \#5: Downloaded survey data.

- Step \#6: Code ${ }^{158}$ and synthesize content analysis and survey data to determine American reaction.

- $\quad$ Step \#7: Collected and performed analysis on U.N. Security Council activities regarding Africa in the post-Cold War era. NVivo software used to code themes.

- Step \#8: Collected and performed analysis on discourse and communication emanating from the U.S. regarding Chinese aid/business activities in Africa postCold War. NVivo used to determine themes of "threat".

- $\quad$ Step \#8: Performed content analysis on official content and speeches presented at the 2014 U.S.-Africa Leaders Summit.

\footnotetext{
158 Coding is done to organize data into chunks that "symbolically assign a summative, salient, essence-
} capturing, and/or evocative attribute” (Saldana, 2011, p. 95). 
- Step \#9: Performed content analysis on public diplomacy from the U.S. to Africa, including blogs, Facebook and Twitter.

- Step \#10: Analyzed all findings to determine whether the U.S. is engaging in symbolic status competition with China on the stage of Africa, in accordance with status theories such as status anxiety and status dissonance. 


\section{SURVEY QUESTIONNAIRE}

\section{U.S. AFRICA FOREIGN POLICY AND PUBLIC DIPLOMACY}

1. How would you describe Africa's overall importance in U.S. foreign policy from the year 2000 to the present?

2. How would you describe U.S. priorities for Africa during this period?

3. Have you seen a change in priorities over time?

4. Have you been involved in planning or executing any programs having to do with policy in Africa?

5. How would you describe the effectiveness of these policies? Have you seen a change from the year 2000 to today?

6. How well do you think the U.S. has been able to use public diplomacy to communicate its message to African publics from the year 2000 to today? Do you have any specific examples?

7. How concerned would you say the U.S. has been from 2000 to today about its image in Africa?

\section{CHINA'S ACTIVITIES IN AFRICA}

1. What kinds of activities have you noticed China carrying out in Africa from the year 2000 to today?

2. What do you believe China's purpose(s) in Africa have been during that period?

3. Has your opinion about the purposes changed over time? If so, how? 
4. Have you ever had a sense that China's activities in Africa were threatening to the U.S., or had stimulated any kind of response?

5. If yes, in what way?

6. Which of the following Forum on China-Africa Cooperation (FOCAC) summit meetings were you aware of (Beijing in 2000, Addis Ababa Ethiopia in 2003, Beijing in 2006, Sharm El Sheikh Egypt in 2009 and Beijing in 2012)?

7. If you were aware, what was your reaction to them?

8. What was the reaction of your colleagues?

9. Were you aware of the kinds of activities pledged by China and Africa in FOCAC meetings?

10. If yes, what was your opinion of these activities?

\section{U.S.-CHINA COMPETITION}

1. How would you describe the relationship between the U.S. and China over the period 2000 to present?

2. Are you aware of China's diplomatic methods in Africa? If so, how would you compare them with those of the U.S.?

3. Do you believe the U.S. has been motivated to become more involved in Africa economically by Chinese activities in Africa?

4. If yes, how do you explain this?

5. If no, why not?

6. Do you believe the U.S. has a fear of "losing" Africa to competitors generally? 
7. If yes, which country does the U.S. most fear?

8. If yes, why do you think the U.S. fears this?

9. If no, why not?

10. Do you believe the U.S. has a fear of "losing" Africa to China specifically?

11. If yes, why?

12. If no, why not?

13. Does Africa's economic potential warrant the attention it has been paid by the U.S. in recent years? Why or why not?

14. Do you believe there is a "resource grab" happening in Africa?

\section{$\underline{\text { U.S.-AFRICA LEADERS SUMMIT (USALS) }}$}

1. Were you involved in planning the 2014 U.S.-Africa Leaders Summit (USALS) in any way?

2. If yes, what was your responsibility (generally)?

3. If no, were you aware of the USALS before, during or after it took place?

4. Why do you believe the U.S. wanted to hold this summit meeting?

5. What is your understanding of the goals and objectives for the U.S. in holding the USALS?

6. Were these goals and objectives met? Why or why not?

7. Are you aware of any mention of Chinese summits or activities in Africa during the planning stages of USALS? If yes, what was said about these summits?

8. Do you believe the USALS was modeled on or inspired by Chinese summits in Africa? Why or why not? 
9. What do you think inspired the U.S. approach to the USALS (i.e., consultation with Africans and NGOs, a “conversation” rather than speeches)?

10. Do you believe the U.S. was able to effectively communicate its message to African leaders and citizens during USALS?

11. In what ways were messages effectively or ineffectively conveyed?

12. Do you believe the U.S. was attempting to "advertise" itself as a better partner for Africa than China during the USALS? If yes, in what ways?

13. What do you think will happen in the next 25 years between the U.S. and Africa, and China and Africa?

14. Is there anything you'd like to add about the relationship between the U.S., China and Africa? 


\title{
SURVEY INVITATION
}

\author{
Vanessa Leon \\ Florida International University \\ Department of Politics and International Relations \\ 11200 SW 8th Street \\ Miami, FL 33199
}

June 5, 2015

\section{PARTICIPANT NAME AND ADDRESS}

\section{Dear PARTICIPANT:}

I am a doctoral student at Florida International University, conducting research on whether the U.S. and China have been engaged in status competition over Africa from the year 2000 to today.

As JOB TITLE, you have a unique perspective on the inner workings of activities between the U.S. and Africa. Your input is vital to understanding how U.S. attitudes and actions toward Africa have evolved during this period of time, and whether they have been influenced by Chinese activities in Africa.

I would like to request your participation in this research study, in the form of an online survey, which will take approximately $30-60$ minutes to complete. Brief followup clarification via email or phone may occur. Your response will be held in the strictest confidence and your participation will be kept anonymous.

\section{To participate, please go to https://www.surveymonkey.com/s/LeonResearch.}

The purpose of this research is to discover how great powers compete on the global stage when they are economically interdependent and wish to avoid an outright military confrontation. A further purpose is to learn how rising powers actually engage with a more powerful state, and strategies they take to avoid direct conflict.

There are no known risks or benefits to participation, and it is completely voluntary. You are free to participate in the study or withdraw your consent at any time during the study. The investigator reserves the right to remove you without your consent at such time that she feels it is in the best interest. Your assistance in conducting this research is genuinely appreciated and I look forward to your response.

Should you have questions, I can be reached at (786) 493-4411 or vleon004@fiu.edu.

Sincerely, 
Vanessa Leon

PhD Candidate, Florida International University

This project IRB-14-0346 was approved for exemption by the Florida International University Office of Research Integrity on 11/19/14. Pertinent questions or concerns about the research, research participants' rights, and/or research-related injuries to participants should be directed to the IRB Coordinator, Maria Melendez-Vargas, telephone (305) 3488311 or mdemelen@fiu.edu. Questions about this research should be addressed to Vanessa Leon, telephone (786) 493-4411 or vleon004@fiu.edu. 


\section{CALCULATION OF THE NATIONAL POWER INDEX (NPI)}

The NPI is a composite of the following five sub-indexes. Each index is briefly explained, followed by its weighing in the NPI in parenthesis, and a breakdown into the numbers used to calculate it. A. Economy Index: Economic security and power (35\%): 1. GDP, 2: Current account balance 3: Public finances, 4: Number of Global 500 corporations $\underline{\text { B. }}$ Military Index: Military security and power (35\%): 1: Nuclear protection, 2: Manpower fit for military service, 3: Military expenditures, 4: Military power projection $\underline{\text { C. }}$ Diplomacy Index: Diplomatic influence (10\%): 1: Size of diplomatic network, 2: UN membership, 3: Permanent UN Security Council membership. C. Technology Index: Technological power (10\%): 1: Number of patents and industrial designs D. Popularity Index: Popularity and influence across the world (10\%): 1: Official development aid, 2: BBC Attitudes towards Countries. 


\section{CALCULATION OF THE QUALITY OF LIFE INDEX}

The Quality of Life Index (QLI) is a composite of the following six sub-indexes. $\underline{\text { A. Health }}$ Index: 1 . Health of the average person, access to and quality of health care (20\%): 2. Life expectancy at birth, 3. Mortality amenable to health care (when available), 4. Infant mortality, 5. Access to health care B. Education Index: 1. Education, access to and quality of education (20\%): 2. Adult literacy rate, 3. School life expectancy, 4. PISA education

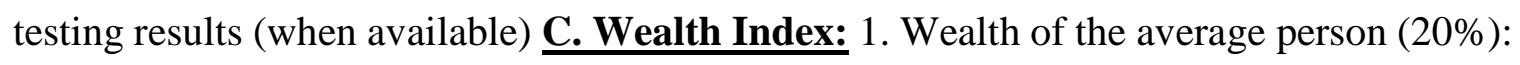
2. GDP (PPP) per capita, 3. Gini coefficient of national income distribution $\underline{\text { D. Democracy }}$ Index: 1. Individual rights and liberties (15\%): 2. Freedom House political rights index, 3. Freedom House civil liberties index, 4. Freedom House freedom of the press index $\underline{\mathbf{E}}$. $\underline{\text { Peace }}^{1} \underline{\text { Index: }}$ 1. Security from crime, repression and armed conflict (15\%): 2. Global Peace Index F. Environment Index: 1. Quality and preservation of the environment (10\%): 2. Environmental Performance Index. 
$\underline{\text { VITA }}$

VANESSA LEON

Born, New Britain, Connecticut

$1998-2001$

B.A., Sociology

Florida International University

Miami, Florida

2007 - 2009

M.A., International Studies

Salve Regina University

Providence, Rhode Island

2010 - 2011

Adjunct Faculty

Miami Dade College

Doral, Florida

2011 - 2016

Doctoral Candidate

Florida International University

Miami, Florida

$2011-2013$

Teaching Assistant

2014 - 2016

Florida International University

Miami, Florida

\section{PUBLICATIONS AND PRESENTATIONS}

"Status Competition Between the U.S. and China on the Stage of Africa," the Annual Meeting of the International Studies Association, Atlanta, Georgia, March 16-19, 2016.

"Signaling the West: Adoption of Western Education Norms," presented at the Annual Meeting of the International Studies Association, San Francisco, California, April 4-6, 2013.

"The Flow of Global Norms: A Case Study of World Bank Influence on Tanzania's Education Policy," presented at the Annual Meeting of the Southern Political Science Association, Orlando, Florida, January 3-5, 2013.

"Peace Through Imitation: A Case Study on Educational Signaling in Core and Periphery States,” presented at the Florida International University Graduate Conference, Miami, Florida, November 17, 2012.

"International Education Competition and American Exceptionalism," presented at the 
Annual Meeting of the Northeastern Political Science Association, Boston, Massachusetts, November 15-17, 2012.

"Reframing Failure to Educate as a Human Rights Violation,” presented at the Annual Meeting of the International Studies Association Northeast, Baltimore, Maryland, November 2-3, 2012.

"Education as Image: Can Remaking an Education System Result in Reimagining of Status?” presented at the Annual Meeting of the International Studies Association South, Atlanta, Georgia, October 12-14, 2012.

"Strengthening of National Ethos in a Connected World," presented at the New Technologies as a Factor of International Relations Conference, Lublin, Poland, May 1618, 2012. 